UNIVERSIDADE DE SÃO PAULO

FACULDADE DE FILOSOFIA, LETRAS E CIÊNCIAS HUMANAS

DEPARTAMENTO DE CIÊNCIA POLÍTICA

PROGRAMA DE PÓS-GRADUAÇÃO EM CIÊNCIA POLÍTICA

\title{
O LIBERALISMO ABRANGENTE DE RONALD DWORKIN
}

\author{
Lilian de Toni Furquim
}

Tese apresentada ao programa de Pósgraduação em Ciência Política do Departamento de Ciência Política, da Faculdade de Filosofia, Letras e Ciências Humanas, da Universidade de São Paulo, para obtenção do título de doutora.

Orientador: Prof. Dr. Cícero Araújo 


\section{LILIAN DE TONI FURQUIM}

O Liberalismo Abrangente de Ronald Dworkin

Tese apresentada ao programa de Pós-graduação em Ciência Política do Departamento de Ciência Política, da Faculdade de Filosofia, Letras e Ciências Humanas, da Universidade de São Paulo, para obtenção do título de doutora.

Área de Concentração: Filosofia Política

Orientador: Prof. Dr. Cícero Araújo

São Paulo

2010 
FURQUIM, Lilian de Toni. O Liberalismo Abrangente de Ronald Dworkin. 2010. Tese (Doutorado) - Faculdade de Historia, Letras e Ciências Humanas, Universidade de São Paulo

\section{ERRATA}

Folha

202 nota 218

202 nota 218
Linha

3

$3 / 4$
Onde se lê

Argumentação moral

Deliberação

política
Leia-se

Deliberação política

Argumentação

moral 
Autorizo a reprodução e divulgação total ou parcial deste trabalho, por qualquer meio convencional ou eletrônico, para fins de estudo e pesquisa, desde que citada a fonte.

Serviço de Biblioteca e Documentação

Faculdade de Filosofia, Letras e Ciências Humanas

Furquim, Lílian de Toni

O liberalismo abrangente de Ronald Dworkin./ Lilian de

Toni Furquim; orientador Cícero de Araújo. - São Paulo, 2010. $234 \mathrm{ff}$.

Tese (doutorado) - Universidade de São Paulo, 2010.

1. Ronald Dworkin. 2. Liberalismo. 3.John Rawls. 4. Igualdade. 5. Teoria da Justiça.

I. Araujo, Cícero. II. O liberalismo abrangente de Ronald Dworkin. 
Nome: FURQUIM, Lilian de Toni

Tìtulo: O liberalismo abrangente de Ronald Dworkin

Tese apresentada ao programa de Pósgraduação em Ciência Política do Departamento de Ciência Política, da Faculdade de Filosofia, Letras e Ciências Humanas, da Universidade de São Paulo, para obtenção do título de doutora.

\section{Aprovado em:}

Banca Examinadora

Prof. Dr.

Instituição:

Julgamento:

Assinatura:

Prof. Dr.

Julgamento:

Instituição:

Assinatura:

Prof. Dr.

Instituição:

Julgamento: Assinatura:

Prof. Dr.

Instituição:

Julgamento:

Assinatura:

Prof. Dr.

Instituição:

Julgamento: Assinatura: 


\section{RESUMO}

O presente trabalho discute o liberalismo abrangente de Ronald Dworkin, como alternativa ao liberalismo político de John Rawls. Dworkin interpreta o liberalismo como uma teoria contínua entre ética e moralidade, ou seja, sem uma separação entre as doutrinas abrangentes e nossas concepções políticas para justificação dos fundamentos constitucionais, respeitando o pluralismo razoável presente na sociedade democrática. O liberalismo abrangente se apresenta como uma teoria liberal na qual a liberdade, a igualdade e a comunidade fazem parte de um único ideal político.

PALAVRAS-CHAVE:

RONALD DWORKIN; LIBERALISMO; JOHN RAWLS; IGUALDADE, TEORIA DA JUSTIÇA. 


\section{ABSTRACT}

The present study discusses Ronald Dworkin's comprehensive liberalism as an alternative to John Rawls'political liberalism. Dworkin construes liberalism as a continuous theory between ethics and morality, that is, without a separation between comprehensive doctrines and our political conceptions so as to justify constitutional grounds, thus respecting the reasonable pluralism existing in democratic society. Comprehensive liberalism presents itself as a liberal theory in which freedom, equality and community merge into a single political ideal.

\section{KEY WORDS:}

RONALD DWORKIN; LIBERALISM; JOHN RAWLS; EQUALITY; THEORY OF JUSTICE. 


\section{AGRADECIMENTOS}

Gostaria de agradecer primeiramente ao Prof. Yoshiaki Nakano que tem meu profundo respeito, admiração e lealdade. Tem me dado a honra de poder contribuir para realizarmos projetos tão importantes. Sem seu apoio não teria sido possível tantas conquistas profissionais e pessoais. Meu profundo agradecimento.

Ao querido Prof. Bresser-Pereira que foi o primeiro a me incentivar a fazer o doutorado em Ciência Política na USP e a quem sempre recorro para ouvir suas sábias orientações.

Ao meu orientador Prof. Cícero Araújo pela disponibilidade, paciência e coragem de orientar uma economista de formação que recém iniciava sua trajetória na nova área.

Um agradecimento especial ao Prof. Gildo Marçal Brandão cuja gentileza, inteligência, humildade e delicadeza marcaram minha passagem pela USP. Deixou-nos tão repentinamente, mas plantou várias sementes ao longo do caminho.

Ao Prof. Ronaldo Pôrto Macedo que me apresentou ao Dworkin filósofo do direito, me auxiliou com bibliografias e me permitiu assistir as suas aulas. Sua ajuda foi fundamental.

Ao Prof. Álvaro de Vita cujo curso me introduziu ao campo vasto e intrigante da filosofia política e que me permitiu dar os primeiros passos para a elaboração deste trabalho.

Ao Prof. Tom Trebat da Columbia University que me aceitou como visiting scholar e permitiu meu acesso ao que de mais novo se discute sobre o tema da minha tese.

Ao Prof. Marcos Fernandes da Silva que me proporcionou importantes discussões sobre justiça e igualdade unindo a economia e a filosofia. Sua companhia ao longo desses anos só me engrandeceu.

Ao meu querido Roberto que esteve ao meu lado acompanhando a realização deste trabalho com amor, carinho e dedicação profundos. Você tornou o exercício de elaborar uma tese muito mais prazeroso.

Ao Francisco e ao João cujas presenças tornaram esta trajetória mais alegre, divertida e desafiadora.

A Lucinda e ao Ednaldo que me fizeram companhia por meses e proporcionaram um ambiente tranqüilo e agradável de trabalho. 
Ao Departamento de Ciência Política da USP, em especial a Rai que me sempre auxiliou com as questões burocráticas com atenção e presteza.

Aos meus colaboradores da Escola de Economia: Deise Esteves minha fiel escudeira, Luciana Bueno, Patricia Fiuza, Andrea, Noelma, Luciana Gabriel, Sumaira, Ronaldo, Roberta, Andrea da Silva e Patrícia dos Anjos.

Aos professores da Escola de Economia da Fundação Getulio Vargas.

Às minhas irmãs queridas Rosali, Marisa e Laís e ao meu irmão Paulo. Ao meu cunhado querido Plínio Paiva.

À minha querida amiga Ingrid que compartilhou esta trajetória desde Nova York. Só nós sabemos como as teses são feitas.

Ao meu pai Paulo Furquim que infelizmente não está aqui para compartilhar da minha alegria. E, finalmente, ao meu querido “paizão” Luis que me deixou cedo demais, mas que fez a grande diferença. 


\section{LISTA DE SIGLAS}

ID “O Império do Direito” de Ronald Dworkin

TJ “Uma Teoria da Justiça” de John Rawls

LDS “Levando os Direitos a Sério” de Ronald Dworkin

LP “O Liberalismo Político” de John Rawls

VS “A Virtude Soberana” de Ronald Dworkin

KC “Kantian Construtivism” de John Rawls

QP “Uma Questão de Princípio” de Ronald Dworkin 


\section{Sumário}

Introdução

Capítulo 1

O Método: Direito, Interpretação e Plateau Igualitário

1.1 Arquimedianismo e os conceitos integrados

1.2 O Debate Hart - Dworkin e a Interpretação Construtiva ....................................31

1.3 O Direito como Integridade e a Verdadeira Comunidade .................................51

1.4 Por onde começamos a interpretação? O Plateau Igualitário..........................65

Capítulo 2

O Liberalismo Abrangente de Dworkin

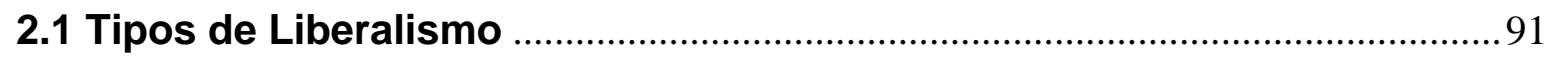

2.2 A Igualdade Liberal e a Métrica do Valor da Vida ............................................97

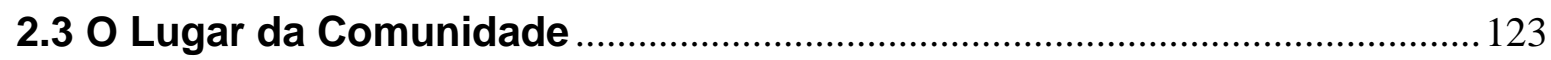

Capítulo 3

A Teoria de Justiça de Dworkin: A Igualdade de Recursos.

3.1 A Igualdade de Bem-estar versus Igualdade de Recursos ……………......136

3.2 A liberdade e seu lugar na igualdade de recursos ........................................... 165

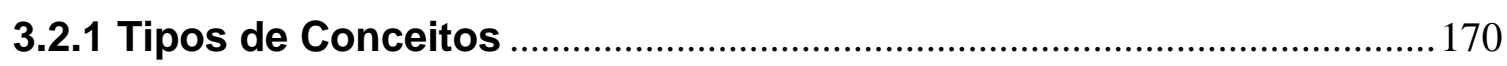

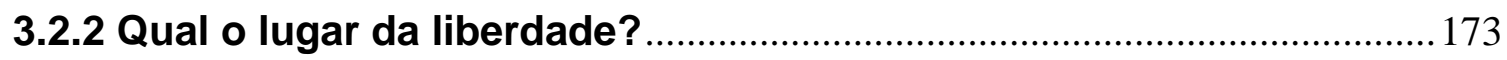

Capítulo 4

Ronald Dworkin e John Rawls: A Prática e a Razão Pública

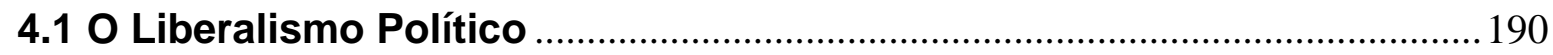

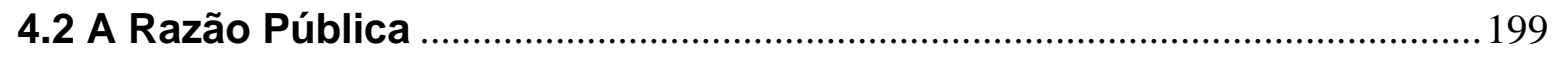

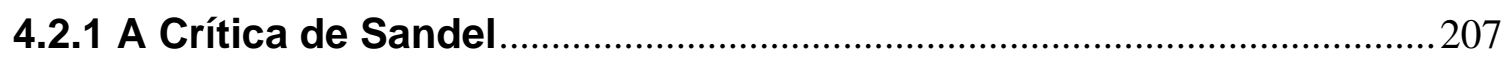

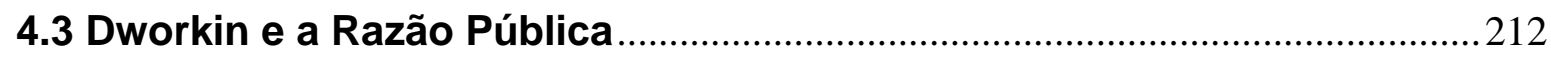

4.4 A Filosofia Prática de Dworkin: Um debate abrangente ..............................214

Conclusão

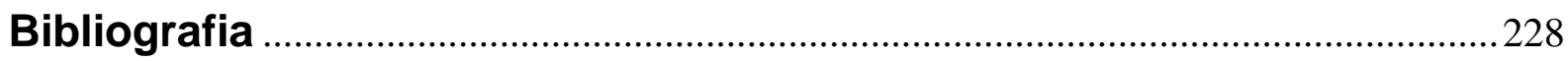




\section{Introdução}

O objetivo do presente trabalho é apresentar a versão alternativa de Ronald Dworkin de liberalismo, a igualdade liberal. Neste trabalho a denominamos liberalismo abrangente para evidenciar seu propósito de ser uma versão contínua entre a ética, o que devemos fazer para alcançar nosso plano de vida, e a moralidade, que é como devemos tratar os outros, em contraposição ao liberalismo político de John Rawls. Neste, Rawls nos apresenta uma concepção política de justiça que separa as doutrinas abrangentes (filosóficas, religiosas, etc) das concepções políticas, tanto na escolha dos princípios, como no conteúdo da razão pública, fundamental para a legitimidade da democracia. Sua preocupação é com a tolerância liberal, ou seja, a neutralidade do Estado em relação às concepções de bem.

Era preciso uma compreensão mais extensa da obra de Dworkin para que o liberalismo abrangente se apresentasse como uma teoria liberal alternativa ao liberalismo político de Rawls. A síntese necessária que este trabalho busca apresentar tem esse propósito, visto que era preciso “juntar as pontas” que apareciam soltas entre seus trabalhos na filosofia do direito e na filosofia política. Era preciso encontrar "um centro de gravidade” para uma discussão mais profunda. Acredito que essa síntese não esgota a instigante agenda de pesquisa sobre as contribuições de Ronald Dworkin, ao contrário, espera ter contribuído para a mesma.

O método utilizado por Dworkin para a construção do liberalismo abrangente levou a diferentes interpretações de conceitos como a igualdade, a liberdade, a justiça e a comunidade. Ele parte do direito abstrato de que todos devem ser tratados com igual consideração e respeito para definir o que venha a ser a melhor interpretação daqueles conceitos. A isso ele chama de plateau igualitário. A origem do método interpretativo construtivo de Dworkin está no seu debate com os positivistas legais, mormente H.L. Hart. Esse método não apenas nos apresenta o seu conceito de direito, mas os conceitos de comunidade, igualdade, liberdade e justiça. Ele acredita que não é 
possível chegarmos à melhor interpretação dos conceitos sem a continuidade entre a ética e a moralidade. Na sua teoria de justiça, Dworkin questiona o suposto conflito entre a igualdade e a liberdade: eles fariam parte de um único ideal político.

Outro ponto importante da discussão de Dworkin é que o liberalismo abrangente tem como valor constitutivo a igualdade e sua profunda conexão com a comunidade, colocando Dworkin entre os liberais igualitários e os comunitaristas. A comunidade na teoria liberal dworkiana tem papel central para o sucesso da vida de seus membros, ele é entendida como um agente moral, sem que isso implique numa concepção metafísica de agência.

Dworkin questiona a neutralidade de justificação que o contrato pretende alcançar com a separação entre doutrinas abrangentes e nossas convicções políticas, sobretudo no conteúdo da razão pública. Aquela neutralidade pode ser alcançada mesmo com a continuidade entre ética e moralidade. Dworkin pretende nos convencer de que, com o seu método interpretativo construtivo, chegaremos a uma definição genuína dos conceitos de igualdade, de liberdade e de comunidade com a continuidade entre a ética e a moralidade. Esse método questiona a estratégia das teorias arquimedianas de justificação moral que partem de fora do campo avaliativo do objeto em questão. Dworkin propõe exatamente o contrário.

No capítulo 1, apresentamos as origens do método interpretativo construtivo utilizado por Dworkin para discutir um novo conceito de direito. Este novo conceito é o direito como integridade. Junto com ele está atrelado o conceito de comunidade personificada, o agente moral que dá a legitimidade para a coerção do Estado. Em seguida, discutimos o ponto de partida para a interpretação construtiva da justiça, o plateau igualitário, o direito abstrato de que todos devem ser tratados com igual consideração e respeito.

No capítulo 2, discutimos como Dworkin constrói seu conceito de liberalismo e seu modelo de métrica do valor da vida, o modelo do desafio, que afirma que o valor da 
vida está no seu enfrentamento e não no impacto que possa gerar na sociedade. O fundamental para o autor é que sejam obedecidos os dois princípios de dignidade: que toda vida tem valor (princípio do valor intrínseco) e que somos responsáveis pelas nossas escolhas (princípio da responsabilidade especial). A seguir apresentamos a relação entre os nossos planos de vida e a comunidade liberal, vista como elemento fundamental a realização daqueles planos. Ao final desse capítulo, teremos as ferramentas para compreender como o autor relaciona a justiça com os conceitos de liberdade e igualdade fundamentais para o capítulo seguinte.

Já no capítulo 3 temos a interpretação de Dworkin do conceito de igualdade, a igualdade de recursos. Apresentamos sistematicamente toda a construção do autor de por quê a igualdade de recursos é a melhor resposta para o que a igualdade requer. Os recursos impessoais são distribuídos por um leilão (mercado) e as desigualdades moralmente inaceitáveis seriam compensadas por um seguro. A igualdade de recursos e a liberdade não estão em conflito. Uma vida boa é aquela que vivemos com o quinhão justo de recursos.

Finalmente, no capítulo 4, estamos em condições de discutir o liberalismo abrangente de Dworkin em relação ao liberalismo político de Rawls, sobretudo no que tange ao conteúdo da razão pública. Esta busca a legitimidade e o exercício da própria democracia deliberativa deixando de fora do debate público, as nossas doutrinas abrangentes. O argumento de Dworkin é que, para atingirmos um common ground para a resolução das controvérsias, devemos fazer uso das doutrinas abrangentes para que o debate seja genuíno e profícuo. O acordo razoável de Dworkin é atingido de forma abrangente, sem a necessidade do contrato e da forma apresentada de razão pública. Concluímos mostrando como o liberalismo abrangente de Dworkin é uma versão em defesa do liberalismo e, principalmente, da igualdade, que aparece como elemento constitutivo. Ainda, abre uma agenda de pesquisa importante para a discussão sobre até que ponto a continuidade entre a ética e a moralidade pode nos ajudar a fortalecer os princípios democráticos, mormente o da tolerância entre indivíduos, grupos e nações. 


\section{Capítulo 1 \\ O Método: Direito, Interpretação e Plateau Igualitário}

O objetivo do primeiro capítulo é mostrar como Dworkin pensa a filosofia do direito e a filosofia política, pois seu projeto, ainda em construção, é elaborar uma "teoria mais geral dos valores humanitários da ética e da moralidade, do status e da integridade do valor, e do caráter e da possibilidade da verdade objetiva” Dworkin (2005: XIV). Se a nossa preocupação é com um liberalismo mais abrangente, precisamos saber como ele o elabora e o justifica. Mostrar como sua versão está estruturada o suficiente para se colocar como uma resposta alternativa ao liberalismo político de Rawls.

Até a apresentação deste trabalho, o autor não havia publicado seu livro "Justice for Hedgehogs"1 que pretende apresentar uma teoria unificada de valor, no entanto, o esforço que estamos fazendo é de evidenciar os elementos já existentes para esse seu projeto filosófico. Quais elementos da teoria de Dworkin nos ajudam a estruturar a sua concepção alternativa de liberalismo - a igualdade liberal - e, de justiça liberal, em comparação à versão mais influente e estudada, o liberalismo político de John Rawls. Dentro dessa perspectiva, Dworkin nos apresenta uma versão de liberalismo mais abrangente porque não separa a ética da moralidade, além de não ser incompatível com a tolerância liberal. Isso porque Dworkin utiliza como método, não o contrato ou o construtivismo político, mas o método interpretativo construtivo. Veremos que a discussão sobre liberalismo, justiça, igualdade e liberdade em Dworkin não poderá estar desassociada da sua filosofia do direito.

A teoria de Rawls com o contrato social bem como os conceitos de “razão pública”, de sociedade e de pessoa, separou da esfera política as chamadas “doutrinas abrangentes”,

\footnotetext{
${ }^{1}$ Uma versão mais longa desse trabalho foi apresentada numa conferência na Boston University School of Law de 25 a 26 de setembro de 2009. O livro ainda passa por revisões do autor.
} 
para garantir a estabilidade do liberalismo diante do "pluralismo razoável”2 produto de instituições livres. O liberalismo político de Rawls se apresenta como uma versão que defende a tolerância diante das diferentes concepções de bem da sociedade. Para isso sua posição de imparcialidade em relação às questões morais que dividem as doutrinas abrangentes é fundamental.

Para compreender o método do autor para "construção" da igualdade liberal, passaremos pela sua crítica ao projeto arquimediano, ao positivismo legal e sua forma de interpretação dos conceitos políticos.

Esta seção nos fornecerá as ferramentas para a compreensão das interpretações que o autor faz para os conceitos como a igualdade, liberdade, direito e comunidade.

Estamos interessados na versão de um liberalismo que não faz uma separação entre a moralidade pessoal (ética) e a moralidade pública ${ }^{3}$. O dilema para o verdadeiro liberal é justamente tolerar concepções de bem que ao mesmo tempo desaprova ${ }^{4}$. Esse poderia ser um dos dilemas de Dworkin, como apresentar um liberalismo que respeita a tolerância e aceita doutrinas abrangentes no seu equilíbrio? ${ }^{5}$ No desenrolar dessa nossa trajetória, esperamos mostrar como é possível responder a estas questões de forma alternativa a Rawls. Para a primeira pergunta podemos dizer que o método interpretativo de Dworkin nos leva a uma versão do liberalismo constituído pelas virtudes da igualdade, liberdade e comunidade de forma interdependente e sem conflito. A forma como definimos os conceitos, segundo ele, será crucial para determinarmos se eles estarão em conflito ou não. Ele responde que o liberalismo tem como virtude constitutiva a igualdade, sempre negligenciada, a comunidade é um agente moral fundamental para a garantia de direitos e deveres, e a da tolerância já que

${ }^{2}$ Os conceitos utilizados por Rawls serão tomados como conhecidos. Apenas apresentaremos definições quando for necessário para o entendimento do argumento.

${ }^{3}$ Vamos usar ética e moralidade no sentido utilizado por Dworkin. Quando falarmos em moralidade é a moralidade pública de como devemos tratar os outros e ética, para moralidade pessoal.

${ }^{4}$ Guest (1997:235).

${ }^{5}$ Para fins de esclarecimento, Dworkin afirma que utiliza a linguagem de equilíbrio emprestada de Rawls. 
ela tem como ideal a integridade. São as obrigações fraternais que determinarão as obrigações políticas e não o contrato e é o sistema jurídico que deverá impedir que grupos tentem impor quaisquer concepções de bem. Temos um longo caminho a percorrer até chegarmos aos exemplos mais recentes de conflitos sobre o que é justo, sobre liberdade de expressão, impostos, aborto, etc, mas mostrar como é possível usar a abordagem dworkiana para uma discussão legítima e produtiva pode ser um caminho enriquecedor.

Se estamos apresentando uma nova versão de liberalismo, podemos nos perguntar como justificá-lo. Uma forma de justificar o liberalismo é pensar que não existe certo ou errado, nos valendo de um relativismo cultural, por exemplo, ou assumindo um ceticismo moral, assim podemos aceitar as diferentes concepções de bem da sociedade. Dworkin e Rawls não são céticos morais, defendem o liberalismo, mas justificam o liberalismo de forma distinta. Mas afinal por que devemos aceitar condutas que achamos repugnantes? Por que aceitar condutas descontínuas em relação a nossas convicções éticas?

Como afirma Vita (2007), o liberalismo tem o mérito de permitir o florescimento dos planos de vida de pessoas em meio ao pluralismo.

“ (...) perante outras teorias políticas devem ser avaliados tendo em vista sua pretensão a ser a doutrina que, se consistentemente aplicada, garantiria o maior espaço possível para p florescimento de diferentes visões sobre o que torna a vida digna de ser vivida." Vita (2007:274).

As decisões pessoais sobre os planos de vida não fazem parte do escopo de uma teoria de justiça, portanto, a imparcialidade exigida é para a justificação dos princípios para a estrutura básica da sociedade. Cada um de nós deve ter autonomia para perseguir aqueles planos de vida. ${ }^{6}$

\footnotetext{
${ }^{6}$ Ver Vita (2007), pp. 274-75.
} 
Uma forma de todos aceitarem diferentes concepções de bem é por meio de um acordo, um consenso que pode ser feito por um contrato social. As partes aceitam voluntariamente os termos desse contrato para poderem viver e realizar seus planos de vida. Rawls escolhe essa via, mas Dworkin não aceita essa forma de justificação moral para o liberalismo. O contrato rompe uma ligação fundamental entre ética e moralidade, já que ele é estabelecido de forma independente das convicções pessoais. Esse é o princípio que rege o véu de ignorância. Em Rawls, as partes na posição original estão sob o véu de ignorância e não têm informações sobre si próprias ou sobre seus gostos e preferências. Não há como a ética participar da escolha preliminar dos princípios de justiça. Essa forma para Rawls é a garantia de escolha de princípios que serão endossados voluntariamente por pessoas livres, iguais e racionais, é o que a prioridade do correto sobre o bem exige. Ou seja, o liberalismo político é endossado por razões independentes da ética privada. A razão pública, que discutiremos no capítulo final, isola as doutrinas morais, filosóficas e religiosas abrangentes da discussão política.

\begin{abstract}
"Isso sugere que deixemos de lado a forma pela qual as doutrinas abrangentes das pessoas se relacionam com o conteúdo da concepção política de justiça, e consideramos esse conteúdo como resultante de várias idéias fundamentais retiradas da cultura da política pública de uma sociedade democrática. Uma forma de expressar isso é colocar as doutrinas abrangentes das pessoas por trás de um véu de ignorância. Isso nos possibilita encontrar uma concepção política de justiça que pode constituir o ponto focal de um consenso sobreposto e, desse modo, servir de base pública de justificação numa sociedade marcada pelo fato do pluralismo razoável.” (LP: 68)
\end{abstract}

Será contra essa versão descontínua que Dworkin apresenta uma discussão profunda sobre o valor da ética para as questões políticas.

O argumento de Dworkin contra o contrato, apresentado em "Levando os Direitos a Sério” (LDS), é que uma concordância hipotética não pode ser uma razão para se aplicar regras como seria no caso de uma concordância real. No caso da posição original o argumento é o seguinte: se as pessoas aceitariam os princípios se fossem consultadas de antemão, então é justo aplicá-los em circunstâncias que não os aceitariam? Precisamos de um argumento independente em favor da equidade dos dois 
princípios sem a necessidade de um contrato. Para Dworkin, a justiça como equidade de Rawls tem como direito fundamental o direito abstrato de igual consideração e respeito. Será por conta desse direito que o contrato será estabelecido e a posição original será uma interpretação do mesmo. De alguma forma Rawls quer garantir que as pessoas escolham os princípios de justiça a partir de uma situação equânime ${ }^{7}$. O contratualismo político oferece uma forma de garantirmos a imparcialidade no nível político dada pela forma como a posição original é definida.

Segundo Vita (2007), é a motivação moral, presente em grau suficiente na conduta humana, que faz com que o acordo seja alcançado.

"Mas somente pessoas para quem a motivação moral for suficientemente forte aceitarão deixar de lado, ao argumentar com outros sobre questões fundamentais de justiça, os fatores que normalmente considerariam importantes de seu ponto de vista individual. Em suma, a motivação moral é o que faz que um acordo sobre princípios comuns de justiça possa ser alcançado. É com base na suposição de que essa motivação se encontra presente em um grau suficiente na conduta humana que podemos afirmar que as partes contratantes aceitarão as restrições impostas por esses princípios às formas pelas quais cada um poderá empenhar-se em realizar seus fins, quer se trate do interesse próprio de indivíduos ou de grupos, quer se trate de determinada visão abrangente do bem." Vita (2007:283).

Mas o que parece sugerir Dworkin é que esse pressuposto de motivação moral não estaria em grau suficiente para garantir a força categórica do contrato. Então, sem o contrato como podemos justificar o liberalismo? Dworkin nos oferece duas formas de resolver o problema: a primeira é considerar a prioridade do correto sobre o bem, assim a moralidade daria conta da esfera política, como no liberalismo político. Mas, segundo ele, não conseguiríamos fazer essa separação entre nossa concepção do bem e

\footnotetext{
${ }^{7}$ Essa discussão de uma teoria profunda por trás da teoria de justiça de Rawls foi feita por Dworkin em LDS. Neste texto ele mostra a diferença entre um modelo construtivo e o modelo natural que utilizaremos mais adiante.
} 
as idéias morais no campo político ${ }^{8}$. A segunda é assumir de vez a continuidade entre ética e moralidade e unir as duas perspectivas adotando o método interpretativo construtivo, cuja origem está na sua crítica aos positivistas legais.

“Take Rawls's political conception of justice which supposedly gains its categorical force, as well as its consensual promise, from the overlapping consensus. We can see that in some sense the principles of this conception are thought by him to be "latent" within the community. An interpretative judgment extrapolates these principles by making best sense of the principles of justice that members of the community actually accept.” Guest (1997: 243).

Para Dworkin ${ }^{9}$, a continuidade não requer que as pessoas definam sua vida em torno da imparcialidade ou da busca pela justiça, mas requer que a discussão pública ressoe nas convicções sobre as nossas concepções de boa vida. É uma idéia de unidade de valor entre a ética e a moralidade que ainda está em construção. Para Guest (2007), a ética pessoal de todos participando desse consenso, mas sem recair numa perspectiva pessoal específica, é o apelo visionário de Dworkin, alternativo ao contrato, para sua versão contínua do liberalismo - a igualdade liberal.

"He [Dworkin] says that in order to succeed in establishing a
liberalism of this kind we will have to show that it has a visionary
appeal, the possibility that it be able to attract support in the form of a
general consensus, and that it will be sufficiently well-justified to
provide what he calls 'categorical force". Guest (1997:240).

Mas se não recai numa perspectiva ética particular, recai em quê? Como garantimos uma imparcialidade apenas no campo político? Onde encontraremos essa justificação moral? Sabemos que Rawls a encontra no equilíbrio reflexivo e o contrato tem a força categórica que aparece na última citação. Ou seja, o contrato visto como fonte de direitos e deveres independente das nossas convicções pessoais. Dworkin, ao

\footnotetext{
${ }^{8}$ Ver discussão de Sandel (1998). Esta não é a única razão para a união da ética com a moralidade. Dworkin acredita que questões morais não podem ser tratadas de outra maneira. A definição de nossas obrigações políticas não pode prescindir dessa relação. O autor considera que a filosofia política tem que pensar a ética e a moralidade de forma integrada, sendo capaz de evitar os conflitos entre conceitos. Ver Dworkin (2006a:160-62).

${ }^{9}$ Ver Ripstein (2007), pp. 1-21.
} 
contrário, imagina um consenso mais geral que daria apoio ao liberalismo abrangente, garantindo a força categórica, com a continuidade entre a ética e a moralidade.

Dworkin não endossa essa força categórica do contrato, ele mesmo afirma que um contrato hipotético não é um contrato ${ }^{10}$.

\begin{abstract}
"Since there are no rights and duties under ordinary contracts before the contract comes into existence, it is impossible to use the idea of an independent contract as the source of the rights and duties that liberalism requires. This is a powerful, simple and obvious argument against the discontinuous contractarian justifications for liberalism. He concludes that discontinuity theories lack categorical force." Guest (1997:241)
\end{abstract}

Ele sugere que a força categórica (direitos e deveres) estaria na união da ética e a moralidade por meio de uma abordagem interpretativa ${ }^{11}$. Desta forma, alcançaria uma teoria de justiça abstrata o suficiente que ofereceria essa força categórica.

Dworkin parte do princípio de que alguns conceitos são interpretativos ${ }^{12}$ como a liberdade, a igualdade, a comunidade, entre outros. Nessa forma de tratar os conceitos interpretativos não podemos separar a ética e a moralidade já que ele é um tipo de equilíbrio mais abrangente ao incluir a ética ${ }^{13}$. Para ele, não se pode traçar uma linha que separe a ética da moralidade no debate público como define a "razão pública" rawlsiana ${ }^{14}$. O que desejamos para as nossas vidas não pode estar separado de como devemos tratar os outros.

“(...) Dworkin also reacts against Rawls, in particular against his view that political philosophy is sharply distinct from the ethical questions that each of us must answer in deciding how to live our lives. As a consequence, he also rejects Rawls's conclusions about the

\footnotetext{
10 LDS:236.

${ }^{11}$ Ver Guest (1997:243).

${ }^{12}$ Ver em “O Império do Direito”(ID) e Dworkin (2001).

${ }^{13}$ Dworkin (2006a).

${ }^{14}$ Razão pública é um conceito apresentado em “O Liberalismo Político”(LP) de Rawls, que será discutido mais à frente nesta tese.
} 
nature of public reason and the types of argument that are acceptable parts of public debate. If political morality and personal morality are continuous, no line can be drawn between those parts of moral argument that are acceptable parts of public discourse and those that are not.” Ripstein (2007: 5).

Temos então o nosso problema: Rawls e Dworkin defendem versões distintas de liberalismo porque utilizam formas diferentes de justificação moral.

Que tipo de legislação deve ser imposta para a preservação ambiental sem prejudicar a produção? Devemos permitir o ensino religioso nas escolas públicas e qual seria? Que tipo de política de cotas adotar nas universidades? São todas questões que exigem uma discussão filosófica. Interpretar aqueles conceitos tem uma função prática fundamental. Quando os nossos valores estão em conflito é preciso encontrar uma forma de discutir e chegarmos a uma melhor solução. Para Dworkin, a forma como definimos conceitos nos dirá se eles vão entrar em conflito ou não. Isso não quer dizer que ele está fazendo uma "conta de chegada”, ou seja, que todo o seu esforço é apenas para mascarar o conflito. Ele genuinamente pensa de forma mais holística, sem uma divisão da ética e da moralidade porque ele acredita que a partir de uma base comum de discussão, na qual colocamos todas as nossas visões de mundo, teremos um debate também genuíno e prático.

Interpretar o conceito de justiça ${ }^{15}$ é diferente de algumas práticas sociais como o direito e traz uma dificuldade a mais. A justiça é um conceito interpretativo mais complexo, porque reivindicamos uma interpretação mais global, diferente, por exemplo, da cortesia ou mesmo do direito que podem ser definidos por práticas locais:

“Conseqüentemente, as margens de segurança da interpretação são muito menos rígidas: não se exige que uma teoria da justiça ofereça uma boa adequação às práticas políticas ou sociais de qualquer comunidade específica, mas apenas às convicções mais abstratas e elementares de cada intérprete.” (ID:40, nota 20).

${ }^{15}$ ID, pp.90-91. 
Portanto, a tarefa do intérprete será buscar um princípio mais abstrato do qual partirá para a busca de um propósito para o conceito, e em seguida, justificar o porquê da importância desse propósito. Resumidamente é isso que se espera de uma interpretação construtiva.

Na interpretação de Dworkin para o liberalismo, a justiça afeta a nossa vida ética, impondo parâmetros, além de determinar as liberdades a que temos direito, por isso a justiça e ética não podem estar separadas ${ }^{16}$. Veremos que a melhor vida que cada um pode ter é a que podemos levar com os recursos disponíveis para nós de acordo com a melhor teoria de justiça distributiva. Isso também une a idéia de boa vida com a teoria de igualdade, ou seja, a vida boa é a vida com a distribuição justa de recursos.

"The result is that justice is to be seen as an integral part of my ethical life and is inseparably connected with my (right) convictions. That means that a proper concern for my own personal ethical life must lead me to a proper concern for the just distribution of freedoms in the community. The continuity between personal ethics and the political structure is, in Dworkin's view, thereby established”. Guest (1997:250).

A forma como Dworkin trata a filosofia política e como veremos do direito ${ }^{17}$ é a forma de pensar do ouriço e não da raposa. Esta é a metáfora grega utilizada por Isaiah Berlin: "the fox know many things, but the hedgehog knows one big thing"18. Ele quer comparar dois tipos de valor moral. A raposa afina-se com o pluralismo moral e o ouriço com o monismo. Para este um único valor ou um grupo restrito de valores está acima dos demais, enquanto que no pluralismo, temos inúmeros valores, conflituosos e incomensuráveis ${ }^{19}$. O exemplo mais marcante é do conflito entre igualdade e liberdade que vamos aprofundar em outro capítulo, mas para Dworkin esse conflito não existe, é

\footnotetext{
${ }^{16}$ Guest (1997).

${ }^{17}$ Ver Introdução de LDS sobre sua crítica à separação da parte normativa da conceitual na teoria dominante do direito. Sua proposta é unir essas duas dimensões na sua teoria liberal do direito.

${ }^{18}$ Berlin (1978) "The Hedgehog and the Fox" in Russian Thinkers, ed. H.Hardy.

${ }^{19}$ Crowder (2003).
} 
falso e serve a propósitos políticos. Segundo ele, os políticos apelam para o valor da liberdade como uma desculpa para ignorar a igualdade ${ }^{20}$.

Claramente Dworkin se intitula um ouriço, mas não assume o monismo de que fala Berlin, ao passo que este é uma raposa. Berlin afirma que o pluralismo está naturalmente mais alinhado com a tolerância, moderação e o liberalismo ${ }^{21}$ porque ele acomoda as escolhas e os conflitos, e o monismo nos levaria a formas totalitárias de governo $^{22}$.

\begin{abstract}
"But Berlin argues that monism is false. The values and purposes of human beings, although universal in part, are multiple, potentially conflicting, and incommensurable. They are so radically distinct that there is no common measure by which they can be ranked in a universal system that will resolve all conflicts. Consequently there can be no perfect society in which all human values are realized simultaneously.” Crowder (2003:9).
\end{abstract}

Podemos dizer que o livro Liberalismo Político de Rawls é uma forma de reconciliar o pluralismo com o liberalismo, e, portanto, com a tolerância liberal. Atualmente, Dworkin está trabalhando na busca desse valor único entre a ética e a moralidade, de como os valores não entram em conflito em clara oposição a Berlin, como o projeto de um “ouriço” não tem implicações totalitárias ou anti-liberais ${ }^{23}$. Na próxima seção apresentamos os adversários de Dworkin, os filósofos arquimedianos e por que os conceitos estão em conflito.

\title{
1.1 Arquimedianismo e os conceitos integrados
}

Nesta seção vamos apresentar a idéia dworkiana que os conceitos políticos são normativos e descritivos, ou seja, não são neutros e que uma filosofia arquimediana,

\footnotetext{
${ }^{20}$ Dworkin (2001).

${ }^{21}$ Crowder (2003:2).

${ }^{22}$ Ver Berlin (2002) “Dois conceitos de Liberdade”, pp. 226-272.

${ }^{23}$ Aqui nos referimos ao seu livro ainda em revisão "Justice for Hedgehogs".
} 
como de Rawls, Berlin e Hart não trataria propriamente os conceitos que estudam. A discussão sobre como definir conceitos é fundamental tanto para o direito quanto para o que nos interessa neste trabalho: a igualdade, a liberdade e a comunidade.

Dworkin contesta o que ele chama de filosofia arquimediana, ou seja, o método de participar “de fora” do campo avaliativo do objeto que se estuda. No que concerne à filosofia, os arquimedianos distinguem o discurso de primeira ordem da sua prática, que é o discurso dos “leigos” ou não-filósofos sobre o certo e errado, do discurso de segunda ordem de sua prática, ou meta-discurso, no qual os conceitos de primeira ordem são definidos e explorados. O grupo de arquimedianos mais conhecido é o dos meta-éticos. A meta-ética discute o status lógico dos julgamentos de valor quando as pessoas leigas falam que algo é moralmente errado ou certo. Para os meta-éticos esses julgamentos de valor são verdadeiros e falsos e, se forem corretos estão relacionados a um fato moral independente. Outro grupo afirma que esses julgamentos morais são expressões de emoções e gostos, algo subjetivo. Mas concordam que suas teorias não são julgamentos de valor, são neutras e desengajadas.

Segundo Dworkin ${ }^{24}$, Hart nos apresentaria uma versão diferente de arquimedianismo. A distinção se dá no nível de discurso, as pessoas leigas discutem a importância relativa de conceitos como democracia, igualdade, liberdade, enquanto que os filósofos buscam saber o que esses conceitos realmente são, sobre o que as pessoas estão em desacordo. Portanto, eles consideram seu trabalho filosófico como neutro. Esse é o ponto de desacordo fundamental entre Dworkin e Hart que veremos mais adiante em detalhe. Para o primeiro questões legais são morais e não neutras, enquanto que para Hart elas são descritivas.

"So we disagree not only about how law is to be identified, but also
about what kind of theory a general answer to that question is. He
believed that such a theory is only and purely a description of legal
practice. I believe that such a theory is an interpretation of legal

${ }^{24}$ Para esta seção seguimos Dworkin (2006a), pp. 140-186, texto originalmente publicado em 2004. 
practice that makes and rests on moral and ethical claims". Dworkin (2006a:145).

Para Dworkin, a versão arquimediana usada por Hart é equivocada e desengajada, já que ele descreve a partir “de fora” das guerras jurídicas. As definições dos conceitos interpretativos como liberdade, igualdade e direito seriam, na visão dworkiana, engajadas e substantivas.

Dworkin diria que os advogados devem decidir pelo princípio que melhor justifica a prática legal como um todo, mas Hart diz que essa resposta deve vir das fontes sociais do direito, como a constituição, as leis, decisões judiciais, etc, sem referência à moralidade $^{25}$, a não ser que tenha sido incorporada pelas próprias fontes sociais. Para os demais conceitos políticos Dworkin acredita que também é interpretativo e que se baseia em questões morais e éticas. Dworkin (2000) vai mostrar em seu capítulo sobre o lugar da liberdade na igualdade de recursos por que os conceitos não entram em conflito quando usamos esse método interpretativo. Tratando os conceitos apropriadamente, temos que liberdade e igualdade são dois conceitos complementares e que fazem parte de um único ideal político ${ }^{26}$.

Os conceitos políticos parecem triviais, mas há algo de especial neles que é negado ou negligenciado pelos arquimedianos. Não podemos nos referir a eles como nos referimos a objetos inanimados. Para estes, podemos usar a descrição, sermos precisos quanto ao seu tamanho, cor, utilidade, mas para conceitos políticos essa técnica será inútil. Mas o que há de especial neles?

Dworkin afirma que alguns filósofos tratam os conceitos acima como um objeto, ou seja, como um exercício descritivo. Ele cita Isaiah Berlin, que define a liberdade como estar livre de restrições ou coerção de outros, a chamada liberdade negativa. Até mesmo leis que coíbem a violência, são consideradas como uma restrição à liberdade e

\footnotetext{
${ }^{25}$ Dworkin (2006) denomina essa forma (em Hart) de como uma lei deve ser identificada em "casos difíceis" como "sources thesis".

${ }^{26}$ Ver capítulo 3 deste trabalho.
} 
insiste que essa definição não é um julgamento de valor, não é um endosso ou uma qualificação da importância da liberdade, mas apenas diz o que é de forma neutra. Essa definição leva a um conflito inevitável com a igualdade: assim qualquer política de impostos tem impacto sobre a liberdade ${ }^{27}$. A escolha, para Berlin, entre as duas virtudes não é uma questão moral ou julgamento político. Ou ainda quando vemos a definição de democracia como a regra da maioria. Nada se diz sobre se é bom ou ruim, qual seu propósito por exemplo. Mas estas, para o arquimedianos, são questões normativas, e dizer o que é democracia é um empreendimento descritivo e conceitual. Suas teorias são descritivas e neutras em relação às controvérsias que lidamos na prática.

Para Dworkin, os arquimedianos ignoram a forma como os conceitos funcionam num debate político. Eles serviriam como um plateau abstrato de acordo ${ }^{28}$ para o início de um debate. Como uma teoria arquimediana daria conta de um conceito como a justiça? O que é justiça é algo que revela profundas controvérsias e não é possível uma teoria neutra e apenas descritiva, a não ser que sejamos céticos. Precisamos escolher um lado, e os próprios filósofos de justiça saberiam disso:

"Philosophers of justice understand that they are taking sides: that
their theories are as normative as the claims about justice and
injustice that politicians, leaders, writers, and citizens make. The
thicker political concepts of liberty, equality, and democracy play the
same role in political argument, and theories about the nature of those
concepts are also normative." Dworkin (2006a:149)

Nas disputas políticas sobre o que é justo, não é possível tratar o conceito de justiça de forma arquimediana, pretensamente neutro. A proposta é que os conceitos políticos teriam elementos descritos e normativos que se interconectam.

"The concepts of liberty, democracy, and the rest function in ordinary thought and speech as interpretative concepts of value: their descriptive sense is contested turns on which assignment of a

\footnotetext{
${ }^{27}$ No último capítulo veremos uma aplicação do método de Dworkin para a religião e os impostos.

${ }^{28}$ Ver aplicação desse conceito em Dworkin (2006b).
} 
descriptive sense best captures or realizes that value. Descriptive meaning cannot be peeled off from evaluative force because the former depends on the latter in that way.” Dworkin (2006a:149).

Como dizer que o projeto filosófico de segunda ordem de identificar um valor político é descritivo e não normativo? Poderia ser uma questão semântica na qual o uso de conceitos como liberdade, justiça e igualdade seriam governados por um critério compartilhado de seus usos corretos e incorretos. Para Dworkin esse critério é válido para objetos e não para conceitos. Não há esse critério compartilhado, sobretudo para o conceito de justiça, ao contrário, esses critérios são os mais diferentes possíveis. Ele usa o exemplo do ouro para nos ajudar a entender essa afirmação. Podemos pensar que uma jóia é feita de ouro, mas para tirarmos essa dúvida podemos fazer um teste químico e verificar se nossa suspeita se confirma. A química nos revela os componentes do que chamamos de ouro. Uma vez analisado, identificaremos se é ouro ou não baseados no seu componente químico. Mas isso serve para esses objetos naturais e não para os conceitos acima:

"...the correct attribution of the concept is fixed by a certain kind of fact about the objects in question, facts that can be the object of very widespread error." Dworkin (2006a: 152).

Assim, a pergunta de Dworkin é se existe alguma estrutura aberta para a análise científica e não-normativa para esses conceitos como fizemos para o ouro? A resposta é negativa e vale para vários outros conceitos e não apenas os políticos. Como ele afirma, a liberdade, igualdade, democracia não têm DNA. A diferença entre as coisas naturais e os conceitos é que a estrutura que explica a manifestação dos primeiros é física enquanto que a dos últimos é normativa. O papel do filósofo é encontrar a natureza dos conceitos revelando seu centro normativo.

"So a general theory about justice will try to capture, at a suitably fundamental level, the value of justice: it will try to show justice, as we might put it, in its best light." Dworkin (2006a:155). 
Mas para isso será necessário descobrir o valor desses valores. A justiça e a liberdade podem melhorar a nossa vida. Dizer que justiça é boa porque a injustiça torna as pessoas infelizes não resolve o problema de definirmos esses conceitos.

Existem duas visões para entendermos a conexão entre compreender um valor e viver bem como conseqüência. Podemos tratar nossos valores como separados e fixados independentemente do que consideramos viver bem ou tratar esses valores integrados ao nosso interesse em viver bem. Neste caso podemos considerar isso como um valor que torna a nossa vida melhor.

As religiões se encaixariam na primeira visão. Não interessa aquilo que podemos considerar como boa vida, esta é determinada pelo respeito a alguma entidade superior a nós. Outro exemplo dado por Dworkin é o valor da arte. Segundo ele, somos responsáveis por encontrar o que há de maravilhoso na arte, mas não podemos considerar que algo é bonito porque faz a nossa vida melhor ao apreciá-la.

O mesmo não podemos dizer da amizade cujo valor está conectado com o papel que ela tem nas nossas vidas. Para uns ela é essencial, para outros nem tanto. O valor dela não é independente do que consideramos sobre a vida com ou sem essas relações. O desacordo estará na forma como ela se encaixaria na nossa vida, visto que é um conceito interpretativo.

“...we may disagree about exactly which ways these are - friendship is an interpretative concept - but no one thinks that friendship would remain something of importance if it turned out to do nothing for the lives of friends, except make then friends.” Dworkin (2006a:158).

A proposta de Dworkin é que não podemos tratar os valores políticos como separados do que consideramos a boa vida. A liberdade, justiça, igualdade, democracia têm valor por causa das conseqüências para as nossas vidas. Considerar os valores políticos separados do que é a boa vida leva-nos a um conflito entre liberdade e igualdade, questão que trataremos mais adiante. 
Para o autor não podemos pensar as virtudes ou valores políticos como algo hierarquizável, mas devemos considerar que estão interligados. Pessoas com maior capacidade de amar ajudaria a torná-las mais humildes e generosas, por exemplo. Essa forma não hierárquica nos dá pistas de por que ele nos apresenta um modelo de valor ético chamado de modelo do desafio, em contraposição ao modelo de impacto. No capítulo seguinte descreveremos de forma mais pormenorizada de que forma esses modelos estão inseridos na sua versão de liberalismo. O modelo de desafio nos diz que o desafio de viver a vida é que tem valor e não o impacto que podemos gerar no mundo. Não é o resultado em si que importa, mas todo o intervalo entre nascer e morrer. Não precisamos ser grandes atletas, pintores, filósofos, mas precisamos viver a vida que escolhemos como modelo.

Com esse modelo, não podemos querer hierarquizar os valores, visto que não temos um modelo geral. Diante disso, precisamos entender os valores de forma holística e interpretativa, e considerar a sua importância à luz da nossa concepção de boa vida. Essa é a justificativa de Dworkin para seu método hermenêutico que trataremos adiante. Assim como Gadamer (1995), nosso autor quer ir além do método das ciências naturais tomando como ponto de partida a experiência concreta dos homens e sua finitude $\mathrm{e}^{29}$.

"If we are better to understand the non-instrumental integrated values of ethics, we must try to understand them holistically and interpretatively, each in the light of the others, organized not in hierarchy but in the fashion of a geodesic dome. We must try to decide what friendship or integrity or style is, and how important these values are, by seeing which conception of each and what assignment of importance to them best fits our sense of the other dimensions of living well, of making a success of the challenge of living a life." Dworkin (2006a: 160).

${ }^{29}$ É a relação entre o sujeito e o objeto do conhecimento que ele resgata e que foi perdido com o método científico. As ciências do espírito, diferente das ciências naturais, requerem essa "imersão" na realidade histórica. 
E ainda, a forma melhor de entender os conceitos políticos é colocá-los numa grande estrutura de forma a que eles reforcem uns aos outros. Dworkin faz isso quando questiona o conflito entre a igualdade e liberdade e afirma que elas fazem parte de um único ideal político. Seu objetivo é mostrar como essas concepções políticas fariam parte de uma estrutura de valor ainda mais inclusiva que conectaria a estrutura política à moralidade, mas também à ética. Será aqui que encontraremos o fio condutor para entender por que Dworkin acredita num liberalismo com fundamento ético.

Aqui residiria sua oposição ao liberalismo político de John Rawls e o pluralismo político de Isaiah Berlin. Berlin condena esse ideal holístico dizendo que "seria um sintoma de uma imaturidade moral e política igualmente profunda e perigosa”30.

A passagem seguinte antecipa o método interpretativo de Dworkin:

\begin{abstract}
"My recommendation is similar to Rawls's method of reflective equilibrium, which aims to bring our intuitions and theories about justice into line with one another. The difference with Rawls's methodology is more striking than the similarities, however, because the equilibrium I believe philosophy must seek is not limited, as his is, to the constitutional essentials of politics, but embraces what he calls a "comprehensive" theory that includes personal morality and ethics as well. If political philosophy is not comprehensive in its ambition it fails to redeem the crucial insight that political values are integrated, not detached." Dworkin (2006: 161).
\end{abstract}

Dworkin revela aqui a limitação do construtivismo político rawlsiano por separar a ética da moralidade e de considerar que devemos seguir uma doutrina da razão pública que apenas permite que tenhamos em pauta as convicções políticas. O objetivo é garantir a tolerância liberal diante das diferentes concepções de boa vida, em outras palavras alcançar a estabilidade de sua teoria de justiça. Obviamente, desta forma, não é possível pensar uma filosofia abrangente como propõe Dworkin.

\footnotetext{
${ }^{30}$ Tradução livre de "is a symptom of an equally deep and more dangerous moral and political immaturity” in Dworkin (2006:106).
} 
Na próxima seção veremos a aplicação do método interpretativo para o direito, sobre o papel da comunidade e dos valores fraternais que corroboram para a sua interpretação do liberalismo.

\subsection{O Debate Hart - Dworkin e a Interpretação Construtiva}

O que é o direito? É com essa questão que Dworkin inicia seu projeto filosófico que desembocará na discussão sobre a necessária continuidade entre ética e moralidade para questões de justiça. O direito é uma prática social como a crítica literária e a moralidade $^{31}$, uma atividade coletiva na qual grupos de pessoas compartilham normas e padrões de crítica.

Durante muitos anos a filosofia do direito foi tomada pelo debate Hart-Dworkin ${ }^{32}$. H.L.Hart publicou O Conceito de Direito em 1961 e recebeu um contra-ataque de Dworkin com seu artigo O Modelo de Regras em 1967, reunido no seu livro Levando os Direitos a Sério ${ }^{33}$ (LDS). Em 1986, em O Império do Direito (ID) apresenta a sua teoria liberal do direito, direito como integridade, no qual, entre outras contribuições, a idéia de que a comunidade é uma “associação fraternal” personificada. O direito como integridade seria a melhor interpretação do conceito de direito. Dworkin coloca no centro de suas preocupações o juiz, diferente da tradição Bentham-Austin-Hart e mais alinhado com a tradição anglo americana do common law. Os juízes estão preocupados com a salvaguarda e aplicação dos direitos, bem como com a interpretação da lei em termos de princípios ${ }^{34}$.

Hart dizia que o direito e a moralidade são conceitos distintos, ou seja, questões sobre direito são diferentes das questões sobre moralidade. Essa forma de tratar o direito foi chamada de positivismo legal, que se apresenta em várias versões, mas para este

\footnotetext{
${ }^{31}$ Mahoney (2004:190).

${ }^{32}$ Ver excelente pesquisa sobre o debate Hart-Dworkin de Shapiro, S. "The Hart-Dworkin Debate: A Short Guide for the Perplexed” in Ripstein (2007), pp. 22-55.

${ }^{33}$ Na verdade são dois textos: “O Modelo de Regras I” e “O Modelos de Regras II.

${ }^{34}$ Conterrell (1987).
} 
trabalho vamos nos concentrar na versão hartiana. As respostas para questões de direito estão nas suas fontes, como a legislação, decisões judiciais, constituição, etc. Dworkin rejeita essa "tese das fontes" do direito e responde que os problemas da teoria do direito são relativos a princípios morais ${ }^{35}$ e questões sobre o direito são questões sobre a justificação moral da coerção do estado. Segundo essa tese das fontes, uma questão legal é normativa apenas quando a fonte social define padrões morais como parte da lei ${ }^{36}$.

Compreender como os juízes decidem é de fundamental importância para a comunidade, dado o forte impacto nas nossas vidas. Por isso, apesar de trivial, devemos perguntar: O que é o direito? E a resposta deverá incorporar a moral. Apesar de não enfatizar em $O$ Império do Direito, Dworkin quer nos apresentar uma concepção de legalidade alternativa à tese das fontes de Hart ${ }^{37}$.

$\mathrm{Na}$ introdução de $\operatorname{LDS}^{38}$ Dworkin antecipa a seus leitores que pretende questionar o que ele chama de teoria dominante do direito e defende uma teoria liberal do direito. A teoria dominante é constituída de duas partes. A primeira é uma teoria sobre o que é direito, ou seja, "uma teoria sobre as condições necessárias e suficientes para a verdade numa proposição jurídica”. ${ }^{39}$ Ela também pode ser chamada de teoria do positivismo jurídico, para a qual a resposta estaria nos fatos a respeito das regras adotadas. A segunda parte da teoria dominante é normativa, ou seja, como as instituições jurídicas devem atuar. Para os defensores da teoria dominante, as duas partes estariam separadas, mas Dworkin defende que uma teoria geral do direito deve

\footnotetext{
${ }^{35}$ Ver “Teoria do Direito” em LDS.

${ }^{36}$ Dworkin (2006a:144).

${ }^{37}$ Ele enfatiza o uso da palavra legalidade em Dworkin (2006a).

${ }^{38}$ Em Levando os Direitos a Sério, (2007) consultar os textos do autor: "Teoria do Direito”, "Modelos de Regras I”, "Modelo de Regras II”, "Casos Difíceis”. Em Uma Questão de Princípio, (2005), consultar os textos: "Não existe mesmo nenhuma resposta certa para os casos controversos?”, "De que maneira o Direito se assemelha à literatura" e "Interpretação e Objetividade".

${ }^{39}$ LDS: V.
} 
ser normativa ${ }^{40}$ e conceitual. Além dessa conexão entre o normativo e o conceitual, essa teoria do direito terá interdependências com outras áreas da filosofia.

\begin{abstract}
"A teoria normativa irá assentar-se em uma teoria moral mais geral, que poderá, por sua vez, depender de teorias filosóficas sobre a natureza humana ou a objetividade da moral. A parte conceitual fará uso da filosofia da linguagem e, portanto, também da lógica e da metafísica. (...) Por essa razão, uma teoria geral do direito deve constantemente adotar uma ou outra das posições em disputa a respeito de problemas da filosofia que não são especificamente jurídicos.” (LDS: X-XI).
\end{abstract}

Bentham propôs uma teoria geral do direito com sua parte conceitual e normativa articuladas. A parte normativa recebeu influências da economia, com a métrica do bem-estar. Neste caso, as decisões jurídicas têm como objetivo geral a maximização do bem-estar geral médio. A sua parte conceitual tem como mais influente contribuição a versão de Hart e será sobre essa versão conceitual que Dworkin dedicará seus esforços argumentativos.

Podemos dizer que o debate Hart- Dworkin está em torno da relação entre direito e moralidade e não se o direito é composto apenas por regras e não por princípios ${ }^{41}$. Dworkin afirma que pela teoria hartiana o direito consiste apenas de regras, nunca de

\footnotetext{
${ }^{40}$ A parte normativa deverá conter uma teoria da legislação, da decisão judicial (adjudication theory) e da observância da lei. A teoria da legislação deve nos dizer por que um determinado grupo ou indivíduo está autorizado a fazer leis, ou seja, uma teoria da legitimidade. Também deve ter uma teoria da justiça legislativa para os tipos de leis que estão autorizados ou obrigados a fazer. A teoria da decisão judicial é composta por uma teoria da controvérsia, que define como os juízes devem decidir os casos difíceis, por uma teoria da jurisdição para explicar por que são os juízes autorizados a tomar as decisões exigidas pela teoria da controvérsia. A teoria da observância da lei é formada por uma teoria do respeito à lei, que vai tratar dos limites do dever dos cidadãos de obedecer à lei, pela teoria da execução da lei. Esta vai nos indicar como e por que das punições implementadas.

${ }^{41}$ Ver Shapiro in Ripstein (2007). Em "Modelo de Regras I" Dworkin faz uma distinção entre regras e princípios. A crítica a Hart é que sua teoria ignora o papel desempenhado por outros padrões que não são regras, sobretudo nos “casos difíceis”. Aqui ele se refere a "princípios” para designar os padrões que não são regras. "(...) aquele tipo de padrão que estabelece um objetivo a ser alcançado, em geral uma melhoria em algum aspecto econômico, político ou social da comunidade (ainda que certos objetivos sejam negativos pelo fato de estipularem que algum estado atual deve ser protegido contra mudanças adversas0" (LDS: 36). As regras são aplicadas à maneira do tudo ou nada, são válidas ou não. Os princípios não são necessariamente conclusivos, depende das circunstâncias da questão. Se duas regras entram em conflito significa que uma delas não pode ser válida, com os princípios a situação é distinta. Quando os princípios entram em conflito, deve-se considerar a força relativa de cada um. No caso de regras, não podemos dizer que uma é mais importante que outra num mesmo sistema de regras.
} 
princípios. Tal distinção tem relação com o poder discricionário do juiz na decisão de casos difíceis. Para Dworkin, mesmo nesses casos, os juízes têm limites para seu poder discricionário, mesmo quando não temos regras e devem utilizar princípios legais. Shapiro (in Ripstein, 2007) afirma que Hart nunca adotou o modelo de regras e eles realmente discordam sobre o alcance do poder discricionário dos juízes nos casos difíceis porque eles têm teorias diferentes sobre a natureza do direito. Hart privilegia os fatos sociais como guias autorizativos, ou seja, o que torna obrigatória uma regra ${ }^{42}$, mas para Dworkin não são apenas os fatos sociais que têm esse poder, mas a moralidade. Esta será um guia autorizativo mesmo que o fato social não o faça, não invalidando, portanto, a noção de que os juízes são limitados mesmo na ausência de regras. A limitação das normas não depende de fatos sociais como na teoria hartiana, mas dos princípios de moralidade política, e é desta forma que ele estabelece a relação entre direito e moralidade. É por isso que, na visão de Dworkin, questões sobre direito são questões sobre moralidade.

\begin{abstract}
"For Hart, a legal rule is a standard that has been identified and selected as binding by some social act, be it an individual directive, a legislative enactment, a judicial decision, an administrative ruling, or a social custom. (...) Hart held that judges must sometimes exercise strong discretion because he takes the law to consist in those standards socially designed as authoritative. Dworkin, on the other hand, believes that judges do not have strong discretion precisely because he denies the centrality of social guidance to determining the existence of content of legal rules." Shapiro in Ripstein (2007:30).
\end{abstract}

Uma crítica importante a Dworkin neste aspecto é que o fato dos juízes serem obrigados a aplicar princípios morais não parece ser suficiente para dizer que o positivismo é falso. Shapiro (in Ripstein 2007) afirma que no ID a discussão está centrada num tipo específico de desacordo, o teórico, que somente seria possível porque são disputas morais. Essa crítica seria muito mais poderosa que a do modelo de regras e, portanto, outro tipo de argumento contra o positivismo. Em um texto mais recente, Dworkin ${ }^{43}$ contesta Shapiro dizendo que não há diferença entre os argumentos

\footnotetext{
${ }^{42}$ Especificamente em Hart a regra de reconhecimento.

${ }^{43}$ Ver capítulo 8 de Dworkin (2006a).
} 
mais antigos e os de “O Império do Direito”. A questão é que não podemos entender as questões legais e a controvérsia sem assumir que as condições de verdade das proposições do direito incluem considerações morais ${ }^{44}$.

Retomando nosso ponto, a teoria dominante do direito tem seu componente utilitarista e positivista. As críticas são inúmeras da esquerda e da direita, mas Dworkin argumenta que elas não enfocam o que realmente é relevante, ou seja, que a teoria dominante é falha porque rejeita a idéia de que os indivíduos possuem direitos anteriores aos definidos por $1 \mathrm{ei}^{45}$. Os críticos condenam a teoria dominante justamente porque ela dá peso excessivo aos direitos individuais e pouca atenção ao coletivismo. Isso viria da proposição de Bentham de que "os direitos naturais não têm lugar em uma metafísica empírica digna de respeito.”46 Os liberais criticam a forma como a noção de sociedade e coletivo é apresentada. Como uma entidade acima dos indivíduos que tivesse "mente” e “corpo” com capacidade para decidir algo por nós. A proposta de Dworkin é a defesa dos direitos individuais sem assumir nenhuma entidade metafísica $^{47}$, mas também sem desprezar a comunidade. O direito como integridade pretende cumprir esse papel. O autor defende os direitos individuais de forma a conciliar o liberalismo com a comunidade ${ }^{48}$, além disso, veremos que a tese de direitos é fundamental para garantir que todos sejam tratados com igual consideração e

\footnotetext{
${ }^{44}$ Dworkin (2006a:234).

${ }^{45}$ A tese de Dworkin é que existem direitos abstratos anteriores a decisões legislativas, que chama de direitos fundamentais (ele evita o uso da palavra natural que causa confusões). Essa análise de direitos fundamentais é utilizada na interpretação do papel da posição original. O direito que está por trás da "teoria profunda" de Rawls é o da igual consideração e respeito, que Dworkin compartilha e serve de base para toda a sua filosofia política. Dworkin procura mostrar que a defesa de direitos individuais não significa desconsiderar os valores da comunidade. Ver LDS, capítulo 6 e sobre a definição de comunidade de ID veremos adiante.

${ }^{46}$ LDS, XIV.

${ }^{47}$ Em ID a comunidade é uma entidade especial sem apelar para uma existência metafísica. Será a "integridade política" que vai supor uma personificação profunda da comunidade. "Pressupõe que a comunidade como um todo pode se engajar nos princípios de equidade, justiça ou devido processo legal adjetivo de algum modo semelhante àquele em que certas pessoas podem engajar-se em convicções, ideais ou projetos, o que a muitos vai parecer uma metafísica ruim.” (ID: 204).

${ }^{48}$ Aqui vale a pena lembrarmos que na discussão sobre a justiça temos um grupo importante de críticos à abordagem liberal por dar muita ênfase aos direitos individuais e negligenciar o papel da comunidade. Dworkin é um liberal, mas enfatiza o papel da comunidade tanto na sua discussão sobre o direito como para a justiça.
} 
respeito, princípio abstrato fundamental que sustenta sua concepção de liberalismo abrangente e sua teoria distributiva. É desta defesa dos direitos que vem sua concepção de que eles são trunfos dos cidadãos:

"Os direitos são trunfos políticos que os indivíduos detêm. Os indivíduos têm direitos quando, por alguma razão, um objetivo comum não configura uma justificativa suficiente para negar-lhes aquilo que, enquanto indivíduos, desejam ter ou fazer, ou quando não há uma justificativa suficiente para lhes impor alguma perda ou dano.” (LDS: XV).

É da definição de direitos e deveres que podemos encontrar a fusão entre a teoria do direito e a filosofia política de Dworkin:

"The connection with law is that making the best sense of the law means making the best moral sense of it and that means making the best sense of it in terms of equality. (...) But because the arguments of equality are relevant to the determination of legal rights and duties, his legal and political philosophy are fused firmly together." Guest (1997:209).

As nossas intuições sobre o que é justiça pressupõem que os indivíduos tenham direitos e que o mais fundamental de todos é o da igual consideração e respeito contida tanto na teoria de Rawls quanto na de Dworkin. A diferença está na interpretação deles sobre o que seja tratar as pessoas com igual consideração e respeito. Adicionalmente, junto com esse princípio abstrato, atuam dois princípios do individualismo ético princípios de dignidade, de que toda a vida é importante, e não deve ser desperdiçada e que todos são responsáveis pelas suas escolhas.

"Se assim for, o direito à consideração e ao respeito é tão fundamental que não pode ser apreendido através da caracterização geral dos direitos como trunfos diante dos objetivos coletivos, a não ser como um caso limite, pois ele é a fonte tanto da autoridade geral dos objetivos coletivos quanto das restrições especiais à autoridade desses objetivos, usadas para justificar direitos mais particulares.” (LDS: XX). 
Significa dizer que esse direito é o que dá a unidade coletiva e não reforça uma noção de individualidade atomista que desconsidera o papel da comunidade na realização dos nossos planos de vida.

Para Dworkin, o direito não é apenas descritivo, ou seja, neutro, mas um exercício interpretativo que busca não apenas descrever o que é, mas justificá-lo, mostrar que ele tem valor e como ele deve ser conduzido para proteger esse valor ${ }^{49}$. Vamos emprestar um exemplo de Dworkin ${ }^{50}$ para ilustrar a afirmação. Quando queremos descrever o que é um livro podemos dizer o que é sem a necessidade de analisar seu conteúdo, dizer se é um romance, poema, ficção ou uma biografia. Um livro contém várias páginas, pode ter formatos diferentes, ter capa dura ou não, ser colorido ou preto e branco, etc. Mas quando falamos de conceitos como a cortesia, podemos dizer que tipos de ações configuram, num determinado país ou época, o que é a cortesia, mas se dissermos: “João foi cortês com Maria”, isso é bom ou ruim? Precisamos de um juízo de valor para entender completamente o que é ser cortês. Por isso, vários conceitos não são compreendidos completamente se apenas descrevermos. É preciso um componente normativo. Para Dworkin, significa dizer que a teoria do direito se baseia em julgamentos morais e éticos. É preciso construir uma ponte entre teoria jurídica e a teoria moral ${ }^{51}$.

Hart questiona no posfácio ${ }^{52}$ de seu livro The Concept of Law, que Dworkin estava errado em criticar o seu projeto e seu caráter descritivo. Para este, Hart é quem estava equivocado em tratar do significado do direito "de fora”:

\footnotetext{
${ }^{49}$ Dworkin (2006a).

${ }^{50}$ Exemplo de ID.

${ }^{51}$ LDS, 21.

${ }^{52}$ O texto "Hart's Postscript and the Point of Political Philosophy” in Dworkin (2006a) é o artigo mais recente sobre o tema de nosso trabalho. Esse artigo foi escrito em resposta a um texto ainda em revisão de Hart publicado pos mortem numa edição mais recente do The Concept of Law.
} 
"But he, on the contrary, simply describes these activities in a general and philosophical way, and describes them from outside, not as an active participant in the legal wars but a disengaged scholar of those wars.” Dworkin (2006a:141).

Então qual a proposta de Dworkin?

A sua teoria de interpretação construtiva foi desenvolvida primeiramente no texto “Hard Cases”, e posteriormente no livro em O Império do Direito no qual apresenta uma teoria liberal do direito alternativa ao positivismo, que ele chama de direito como integridade. Segundo ele, o método interpretativo é o mais adequado para tratarmos de práticas sociais ou de conceitos normativos, já que a descrição não daria conta de nos esclarecer o significado do conceito ${ }^{53}$.

A importância em responder “o que é o direito” em Dworkin está no fato de que somos “súditos do império do direito, vassalos de seus métodos e ideais, subjugados em

${ }^{53}$ Estamos no campo da hermenêutica, ou "hermenêutica pós-positivista” e Dworkin foi influenciado pela literatura filosófica da interpretação em Dilthey, Habermas e em Hans-Georg Gadamer. Dworkin defende a idéia de que a interpretação criativa não é conversacional, mas construtiva, diferente dos teóricos da literatura. Para eles interpretar uma obra literária é capturar as intenções do autor. Mais adiante, Dworkin ressalta que Gadamer (ver Verdade e Método, 2004) faz uma observação fundamental ao dizer que a interpretação reconheceria as imposições da história, mas também luta contra ela, mostrando que a interpretação não é um ponto de Arquimedes, mas participa "de dentro". Ou ainda, quando novamente ele cita Gadamer ao afirmar que a "interpretação deve pôr em prática uma intenção" (ID:67). Aqui Dworkin quer dizer que a interpretação não é simplesmente a reconstrução da intenção do autor, mas o relato de um propósito. É uma proposta do intérprete de uma forma de ver o que é interpretado, pode ser uma prática social, texto ou pintura. Gadamer foi além da metodologia científica e avançou para os domínios da arte, das ciências, do espírito e da linguagem. Ele estava buscando a morada da verdade. A experiência interpretativa para Gadamer repousa na própria "experiência mundana”, na realidade histórica, na experiência, no tempo e na tradição (ver em Côrtes, 2006). Por isso não podemos pensar em ponto arquimediano. Para ele a participação do intérprete com seus pré-conceitos é fundamental para o sentido da compreensão. “(...) o mundo resulta dos esforços compartilhados, interativos e auto-interpretativos (hermenêuticos) dos seus agentes constituintes. Ele não se exibe simplesmente como um agregado caótico de entes substantivos, mas revela-se e é laboriosamente construído em uma espécie de contrato ontológico perenemente negociado que, ao predicar suas propriedades - através de um acordo conflituoso que distingue o certo e o errado, o falso e o verdadeiro, o meu e o teu, o bem e o mal, a obediência e o mando, o sujo e o limpo etc.- , define e estabelece tudo aquilo que é.” Côrtes (2006: 278). Nada mais dworkiano. 
espírito enquanto discutimos o que devemos, portanto fazer”, ${ }^{\text {„4 }}$. O raciocínio jurídico é um exercício de interpretação construtiva e é essa forma de pensar que vamos expor.

Os conceitos interpretativos não estão “em algum lugar” para serem descobertos, precisam ser construídos. Ele parece nos forçar a encontrar uma unidade que parece difícil de tratar.

\begin{abstract}
“(...) Dworkin affirms that judicial interpretation can and must be based on principle and that aim of principled interpretation on the complex detail of law is to mold the whole of it, as far as possible, into a morally unified structure founded on consistent, though not necessarily uncontroversial, political and moral conceptions. Over the apparent complexity, inconsistencies, and, some would say, chaos of contemporary regulation Dworkin superimposes an image of law as unified, morally dignified, and intellectually consistent. The guardians of this integrated philosophical world of law, a world very different perhaps from what legal experience suggests to some of us, are the judges.” Cotterrell (1987:512)
\end{abstract}

Para o autor, quando ele argumenta que existem respostas para os casos difíceis e que podem ser procuradas pela razão e pela imaginação, significa que a controvérsia com os céticos se baseia na moral e não na metafísica e, por isso, a tese de inexistência de respostas certas seria pouco convincente.

Ripstein (2007) antecipa que se Dworkin estiver certo que o direito é um conceito interpretativo, assim como os demais conceitos normativos, não podemos ter uma teoria arquimediana puramente conceitual sobre o direito, o mesmo valendo também sobre a justiça. Argumentos conceituais não são interpretativos.

Somente com o entendimento da divergência teórica no direito será possível criar uma teoria sobre os fundamentos apropriados do direito.

${ }^{54}$ ID: XI. 
De forma resumida os juízes, segundo Dworkin, podem divergir de duas formas a propósito da verdade de uma “proposição jurídica”: a "divergência teórica” e “empírica”. Proposições jurídicas são as alegações que fazemos sobre aquilo que a lei nos permite, proíbe ou autoriza. Podemos usar o exemplo do autor: a lei não prevê indenizações de uma empresa quando o funcionário é ferido por outro funcionário. Essa é uma proposição jurídica.

Mas o que são essas divergências teóricas e empíricas? As divergências teóricas são aquelas relacionadas aos “fundamentos do direito", sobre o que o direito realmente é. Os fundamentos do direito são proposições mais conhecidas que nos dizem se as proposições jurídicas são verdadeiras ou falsas. A divergência empírica trata daquilo que as instituições decidiram anteriormente, por exemplo, de por que foi decidido que não podemos fumar em determinados locais. Para Dworkin, a verdadeira divergência é a teórica e não existe uma teoria para tratarmos dessa questão. Querem nos convencer que a divergência teórica seria uma ilusão e que os operadores do direito estão de acordo quanto aos seus fundamentos. Que o direito seria uma questão de simples fato (plain fact), que suas questões poderiam ser tratadas com a consulta aos arquivos das decisões institucionais, e não dependeria da noção daquilo que ele deveria ser. Quando nenhuma decisão foi dada para um determinado caso, então o juiz deve exercer seu discernimento ou poder discricionário. Mas Dworkin não aceita essa afirmação, mesmo que tenhamos que consultar as decisões anteriores, isso não nega a importância da moralidade. Para ele, o ponto de vista do direito como simples fato seria mais uma evasiva que uma teoria. De fato, não temos uma teoria sobre a qual nos apoiar para fazer uma crítica à forma como os juízes tomam as suas decisões. Isso se torna ainda mais importante quando os juízes ficam diante dos chamados casos difíceis (hard cases) para os quais não temos uma decisão anterior ou regra. Então como deliberar?

O direito como uma prática argumentativa pode ser estudado do ponto de vista do sociólogo ou do historiador, que é externo, ou podemos usar o ponto de vista interno daqueles que fazem as reivindicações. Dworkin opta pelo segundo, do juiz, porque ele considera que o argumento jurídico dos processos judiciais é o ponto de partida para 
analisar a prática jurídica. Além disso, esses argumentos jurídicos e o raciocínio dos juízes têm influência sobre "outras formas de discurso legal que não é totalmente recíproca” ${ }^{35}$. Ao contrário de Hart ${ }^{56}$, Dworkin não faz um estudo sociológico do direito, mas filosófico ${ }^{57}$.

Os positivistas aceitam a tese do simples fato e que a verdadeira divergência sobre o direito é do tipo empírica sobre a história das instituições jurídicas. O positivismo é um tipo de teoria semântica ${ }^{58}$, assume que os operadores do direito usam os mesmos critérios para afirmar se uma proposição jurídica é falsa ou verdadeira. Hart afirmava que os verdadeiros fundamentos do direito encontravam-se na aceitação, por parte da comunidade como um todo, de uma regra mestra fundamental (regra do reconhecimento) que atribui a pessoas ou grupos específicos a autoridade de criar leis. Os debates que se seguiram giravam em torno da pergunta: o que consistia a aceitação da regra de reconhecimento? O que ganhou enorme aceitação na academia é que a verdade das proposições jurídicas dependia essencialmente dos padrões convencionais de reconhecimento do direito.

Para Dworkin, a divergência está no verdadeiro conteúdo do direito. Ele questiona o que chama de "aguilhão semântico" que diz que as pessoas somente poderão divergir se compartilharem os mesmos critérios para decidir quando uma afirmação sobre o direito é verdadeira ou não. Se não compartilharem os mesmos critérios, então não há acordo ou desacordo. Assim, precisamos das teorias semânticas para descobrir os

\footnotetext{
${ }^{55}$ ID:19.

${ }^{56}$ Hart afirma que seu livro sobre o conceito de direito é "um ensaio de sociologia descritiva; porque a sugestão de que as investigações sobre os significados das palavras apenas lançam luz sobre palavras é falsa. Muitas distinções importantes, que não são imediatamente óbvias, entre tipos de situações ou relações sociais, podem ser mais bem trazidas à luz por um exame dos usos-padrão de expressões relevantes e do modo por que estes dependem de um contexto social, ele próprio deixado frequentemente por afirmar.” Hart (1994:1-2).

${ }^{57}$ ID, p. 54.

${ }^{58}$ As teorias semânticas são aquelas que dizem que os advogados e juízes compartilham critérios lingüísticos para avaliar as proposições jurídicas. Dworkin faz uma distinção entre as teorias que tratam de definições do direito e as mais sofisticadas, influenciadas pelos filósofos da linguagem, as teorias sobre o "uso" dos conceitos jurídicos. O positivismo seria um tipo de teoria semântica. ID, p.40, nota 29 .
} 
critérios. Mas as divergências apontadas por essas teorias não se ajustam ao que realmente ocorre nas decisões dos juízes. Se acreditarmos que as divergências têm aquele caráter então fomos apanhados pelo aguilhão.

A divergência pode ser genuína mesmo que os critérios usados para as interpretações sejam diferentes. Ao final a divergência é genuína porque as interpretações divergentes se voltam para os objetos a serem interpretados. $\mathrm{O}$ autor usa as regras de cortesia para nos auxiliar no entendimento da atitude interpretativa.

Numa sociedade fictícia, seus membros seguem um conjunto de regras de cortesia, e por certo tempo ninguém questiona sua existência ou tenta modificar. Mas um dia isso muda e as pessoas desenvolvem uma atitude interpretativa com relação àquelas regras. Essa atitude tem dois componentes: o primeiro é a noção de valor da prática, de que ela tem alguma finalidade ou interesse, e o segundo é que as exigências da prática da cortesia são suscetíveis a sua finalidade, verificam o que ela requer, seu conteúdo. A atitude interpretativa que se desenvolve gera um significado para a prática e buscam reestruturar para atender a esse significado. Ou, como fala Dworkin, "vê-la [a prática] em sua melhor luz"59. Um propósito torna o objeto o melhor que ele pode ser quando o mesmo “se ajusta” e "justifica” o objeto melhor que as demais interpretações disponíveis. Quando se ajusta, a interpretação recomenda que esse objeto existe e tem as propriedades que tem e justifica (moralmente) quando o propósito vale a pena ser alcançado. Para os objetivos do autor, precisamos que os dois componentes ${ }^{60}$ sejam adotados para a prática da cortesia, assim o valor e conteúdo da mesma se fundem.

Digamos que a finalidade da cortesia seja demonstrar o respeito aos membros superiores da hierarquia social, mas com o florescimento da atitude interpretativa modifica-se a própria idéia de respeito. A interpretação repercute na prática e muda a

\footnotetext{
${ }^{59}$ ID: 58.

${ }^{60} \mathrm{O}$ autor coloca que os dois componentes são independentes e nem sempre são aplicados conjuntamente, como no caso dos jogos e competições. Não se pode, a cada jogo, a cada circunstância, modificar as regras, por isso apenas aplicamos o primeiro componente.
} 
sua forma ${ }^{61}$. A finalidade da cortesia pode ser totalmente alterada até chegarmos ao estado mecânico de adoção da prática, sem questionamentos.

Agora é preciso ver como a atitude interpretativa, a dinâmica da mudança da finalidade, funciona do ponto de vista dos intérpretes como foi citado anteriormente. A tarefa de Dworkin não é simples porque o próprio conceito de interpretação é também interpretativo: "uma teoria da interpretação é uma interpretação da prática dominante de usar conceitos interpretativos" ${ }^{\prime 2}$.

Existem vários tipos de interpretação, como a científica ou a artística, e a interpretação da prática social como a cortesia ou o direito se assemelha à última. Tanto a interpretação artística como da prática social são interpretações criativas já que partem de algo criado pelas pessoas como uma entidade distinta, separada.

A diferença da interpretação criativa em relação à interpretação científica e da conversação, na qual interpretamos sinais e sons é “(...) neither of these two sorts of interpretation requires proposing human interests or goals or principles.” Guest (1997:27).

"Em linhas gerais, a interpretação construtiva é uma questão de impor um propósito a um objeto ou prática, a fim de torná-lo o melhor exemplo possível da forma ou do gênero aos quais se imagina que pertençam”. (ID: 64).

A interpretação criativa é "construtiva” e se preocupa com o propósito do intérprete. Para essa "construção" vamos partir de uma base, da história e da própria forma da prática impondo limites sobre as interpretações possíveis. Não podemos definir o que é liberdade ou direito da forma como desejamos. Essa interpretação criativa requer uma interação entre propósito e objeto.

\footnotetext{
${ }^{61}$ O método de Dworkin recebeu inúmeras críticas e contribuições. Para uma discussão interessante sobre o tema, ver Marmor (2004).

${ }^{62}$ ID: 60.
} 
Para Brown (2009), o método de Dworkin possui dois elementos: o construtivo e o interpretativo. O construtivo, ao contrário do intuicionismo, não trata as intuições como pistas para a existência de princípios independentes, mas como elementos de uma teoria mais geral a ser construída. Ainda, não assume que os princípios de justiça possuem uma existência objetiva, fixa, eles podem ser verdadeiros ou falsos. O modelo interpretativo tem como objetivo buscar, dentre as teorias mais gerais, a melhor interpretação. Evidentemente isso vai envolver disputas, mas então qual é a melhor interpretação? Para encontrarmos a melhor interpretação é preciso atender a dois requisitos. O primeiro é buscar um bom “encaixe aos dados” e, adicionalmente, requer que a interpretação seja contínua com a nossa moralidade.

"Dworkin also suggests that a good interpretation of the concept of justice must be 'continuous' with our conventional personal ethics. We have every reason to be skeptical of an interpretation of justice in public life that depends on normative ideas which cut against the grain of our conventional personal ethics (as in people's ordinary ethical experience).” Brown (2009: 12)

O segundo requisito é que a interpretação seja atraente, ou seja, não basta encaixar nos dados é preciso ser a melhor que pode ser. A melhor interpretação deverá nos mostrar as funções desse conceito para a nossa vida e apresentar os valores que as pessoas compartilham.

\footnotetext{
"Like practices, showing a concept in its best possible light may involve both identifying the particular functions it serves in our lives presenting it in terms of deeper values that many people share, so that the best interpretation of the concept is the one that best encapsulates those deeper values.” Brown (2009:12).
}

Quando começamos a buscar o valor da prática a partir de dados brutos podemos não chegar a um único valor. O intérprete deverá escolher entre as interpretações que, segundo ele, atribui máximo valor à prática. O que difere entre os tipos de interpretação são os critérios para mostrarmos o objeto na sua melhor luz. $\mathrm{Na}$ 
interpretação artística, os critérios são distintos da científica: por exemplo, interpretar uma peça é diferente de um fenômeno físico.

"Quero dizer que uma interpretação é, por natureza, o relato de um propósito; ele propõe uma forma de ver o que é interpretado - uma prática social ou uma tradição, tanto quanto um texto ou uma pintura - como se este fosse o produto de uma decisão de perseguir um conjunto de temas, visões ou objetivos, uma direção em vez de outra." (ID: 71).

Mais importante para Dworkin é mostrar que a interpretação não é um ponto de Arquimedes, ou seja, não se pode imaginar um intérprete alheio ao seu objeto, alheio às intenções do autor, mas ele não poderá esquecer o papel da história para limitar as interpretações possíveis.

Para interpretarmos uma prática social, será preciso distinguir entre interpretar os atos e pensamentos individuais (interpretação conversacional), e interpretar a prática em si, ou seja, o que se faz coletivamente. Em outras palavras, é saber distinguir o que outros membros pensam que a prática exige daquilo que ela realmente requer.

O cientista social deve interpretar o ato coletivo como um participante virtual das práticas que deseja descrever a sua versão competirá com a versão dos demais membros da comunidade. Aqui vemos a influência de Habermas ${ }^{63}$, já que para Dworkin o intérprete deve “participar do espírito de seus participantes”, “aderir à prática” que pretende compreender, desta forma os resultados não serão relatos neutros.

\footnotetext{
${ }^{63}$ Dworkin afirma que para Habermas há uma diferença entre a ciência social e a natural. No caso dos cientistas sociais, os dados já estariam pré-interpretados e, portanto, não é neutra como pretende um fenômeno natural. "Os cientistas sociais já encontram seus dados pré-interpretados. Devem compreender o comportamento do modo que este já é compreendido pelas pessoas que têm tal comportamento; um cientista social deve ser pelo menos um participante "virtual” das práticas que pretende descrever. Deve estar pronto a julgar, bem como a reportar, as afirmações que fazem seus sujeitos, pois, a menos que possa julgá-los, não poderá compreendê-los”. (ID: 78, nota 14).
} 
A interpretação construtiva é constituída de três etapas: a pré-interpretativa, interpretativa e pós-interpretativa. Na etapa “pré-interpretativa” identificamos as regras e os padrões que podem nos dar o conteúdo da prática. Mesmo nessa fase se exige algum grau de interpretação. Dworkin considera que nesta fase é preciso um alto grau de consenso para que a atitude interpretativa floresça. A segunda etapa é a interpretativa, nesta o intérprete deve apresentar uma justificativa geral para os principais elementos da prática identificada na etapa anterior. Essa justificativa não precisa se ajustar perfeitamente à prática, basta que o intérprete considere que está interpretando e não inventando uma nova prática.

A terceira etapa é a pós- interpretativa, ou reformuladora, que consiste no ajuste da idéia do intérprete àquilo que a prática realmente requer para melhor servir à justificativa que ele aceita na etapa interpretativa.

Dworkin resume as três etapas tomando emprestado de Rawls a idéia equilíbrio entre a justificativa da prática e suas exigências pós-interpretativas. Rawls, ao contrário, busca um equilíbrio entre intuições sobre a justiça e uma teoria formal que une essas intuições ${ }^{64}$. Aliás, em um texto mais recente, afirma que a contribuição de Rawls para a filosofia do direito está na idéia da interpretação pelo equilíbrio reflexivo:

"So Rawls recommended that philosophers of justice engage in the interpretative enterprise he called seeking reflective equilibrium. We try to generate principles of some general scope and to match those general principles to the concrete judgments about what is just and unjust with which we begin, shifting our views about either principles or concrete judgments, or both, as becomes necessary to achieve an interpretative fit. We can restate this interpretative exercise as a method for legal philosophy.(...) That interpretative design provides the best way of understanding the arguments that leading legal philosophers have actually made. (...) So Rawls's work is, right from the start, a major contribution to legal philosophy's selfunderstanding.” Dworkin (2006a:246-47).

${ }^{64}$ ID: 82, nota 17. 
Veremos que a crítica de Dworkin está na estrutura da razão pública, que exclui do processo interpretativo as doutrinas abrangentes. A interpretação justamente cumpre o seu papel mantendo-as presentes. Muitas vezes a interpretação seria um ato de "ver” um propósito ou objetivo da prática e depois partir para a fase pós-interpretativa. Obviamente abre terreno para inúmeras controvérsias.

As pessoas precisam de certas convicções ou crenças para interpretar, caso contrário serão incapazes de dizer o que será válido para uma etapa pré-interpretativa de uma determinada prática social. Também serão necessárias convicções, para definirem até que ponto a justificativa da fase interpretativa se ajusta às características da prática. Ou seja, nos dizer se está realmente interpretando a prática ou inventando algo novo. Se houver muita discrepância sobre essas convicções, não será possível fazer o ajuste. A história poderá nos dizer se a discrepância é excessiva ou não. Por último, vamos precisar de convicções, chamadas de substantivas, sobre que tipos de justificativas mostram a prática na sua melhor luz, mas estas não precisam ser tão compartilhadas como as anteriores. Esse último tipo de convicção deve ser independente do segundo grupo de convicções, as de adequação. Segundo Dworkin, se não houver independência, as últimas não poderão exercer coerção sobre as primeiras, impedindo a identificação entre o que é interpretação de invenção ${ }^{65}$.

Como seria a interpretação do conceito de justiça? Também neste caso podemos ser alvo do aguilhão semântico e, como com a cortesia, tem uma história quando desenvolvemos nossa atitude interpretativa. Em QP ${ }^{66}$, Dworkin ressalta que a justiça deve ser a nossa crítica, não nosso espelho, visto que sempre podemos questionar e discutir se algum esquema institucional é justo, independente das tradições que estão sendo contestadas. A atitude interpretativa da justiça parece sempre viva.

\footnotetext{
${ }^{65}$ Dworkin define que certas exigências de uma prática social, como no caso da cortesia os homens devem levantar-se quando uma mulher entra na sala são consideradas paradigmas numa certa época. Uma interpretação plausível deve ser capaz de ajustar-se aos paradigmas. Os paradigmas fixam as interpretações, mas não estão livres de uma contestação por uma nova interpretação que melhor se ajuste a outros paradigmas. Ver (ID: 89).

${ }^{66}$ Ver (QP: 326-27).
} 
Uma observação importante é que Dworkin não considera que interpretar a justiça seja igual à cortesia. A primeira é muito mais complexa e usar a cortesia como analogia também não é tão útil como é para o direito. Em uma longa nota de rodapé, ele afirma que a justiça tem um alcance global. Para entendermos a justiça como um conceito interpretativo precisamos considerar as concepções de justiça de diferentes indivíduos e essa interpretação servirá de base para criticarmos as práticas de justiça de outras pessoas, de outras comunidades. A interpretação sofre uma modificação porque uma teoria de justiça deve se ajustar a convicções abstratas e elementares de cada intérprete e não a práticas sociais de uma comunidade específica. Ainda, não podemos usar o conceito de justiça para interpretar a justiça, como a usamos para o direito.

“(...) é natural que nos voltemos para uma justificativa de idéias inicialmente não políticas, como a natureza humana ou a teoria do eu, e não para outras idéias políticas que não parecem mais importantes ou fundamentais que a própria justiça.” (ID: 91, nota 20).

Mas a justiça tem uma história como a cortesia, e suas interpretações têm ficado mais complexas com o tempo. Nós temos nossas concepções de justiça sem pensar que são interpretações e que passamos pelas três etapas interpretativas anteriores. Assim, o filósofo político deverá encontrar a melhor concepção ${ }^{67}$ para o conceito de justiça. Deve tentar partir de uma proposição abstrata para definir o conceito de justiça e assim tomar os argumentos sobre a justiça como pertencentes à melhor concepção sobre o conceito.

Chegar à melhor interpretação de justiça não é tarefa fácil porque os filósofos precisam chegar a uma formulação do conceito que seja suficientemente abstrata para sua aceitação na comunidade. Dworkin chega a afirmar que o trabalho dos filósofos da justiça “(...) consiste não em tentar formular o conceito de justiça, nem em redefinir

\footnotetext{
${ }^{67}$ Dworkin explica a diferença entre conceito e concepção da seguinte forma: o respeito oferece um conceito de cortesia, as visões antagônicas desse conceito são concepções do mesmo. (ID: 86-87).
} 
os paradigmas, mas em desenvolver e defender teorias polêmicas que vão bem além dos paradigmas e chegam à esfera política” (ID:93). Pareceria indicar que os filósofos não arriscam uma atitude interpretativa mais séria já que não questionam os paradigmas de sua época com novas interpretações? Ele não é claro. Mais adiante no texto ele não nega que as concepções de justiça existentes não sejam interpretações, mas afirma que não são neutras e seu valor está no compromisso da defesa de suas concepções. Como apresentado anteriormente, os filósofos da justiça sabem que estão escolhendo lados.

Para Brown (2009), o método de Dworkin é superior porque, entre outras coisas, busca fazer do objeto o melhor possível e permite, ao interpretar os dados, encontrar várias explicações e valores para as instituições ou práticas.

\begin{abstract}
"The aim is to render more explicit these existing ideas whilst at the same time being faithful to the intentions of the creators of these institutions. The ambition of constructive interpretation, by contrast, is to make its subject the best it can be and where necessary to impose an interpretation of its point or value. So what makes the interpretation successful is not that it explains what is already widely supposed to be the case, but that it shows its subject in its best light." Brown (2009:15).
\end{abstract}

Mas podemos garantir que uma interpretação é melhor que outra? Como Dworkin responde a esta questão?

Podemos iniciar a resposta dizendo que Dworkin ${ }^{68}$ não é um cético moral, ele acredita que possamos encontrar respostas certas e erradas para as questões normativas. $\mathrm{O}$ cético interno se apóia na força de sua interpretação em relação às demais como a certa. A preocupação de Dworkin é com um ceticismo interno global, ou seja, que questiona todas as interpretações acerca do direito. Essa posição é diferente do cético externo, que não se apóia em nenhuma interpretação ou questão moral para contestar

\footnotetext{
${ }^{68}$ Ver sua discussão sobre ceticismo em Dworkin (1996).
} 
um argumento. Apenas afirma que as opiniões são "projetadas na realidade”, e não descobertas nela.

Realmente não é possível demonstrar que uma afirmação moral é verdadeira ou falsa como se faz nas ciências naturais, no entanto isso não quer dizer que não podemos encontrar as respostas certas. O que vai nos ajudar a comprovar as nossas questões morais é um argumento autônomo às afirmações que fizemos.

A linguagem vai nos ajudar a reforçar o conteúdo de nossas afirmações e esclarecer que se trata de um juízo moral e não de uma mera opinião. Quando a divergência é genuína, ela somente poderá ser contestada por outros argumentos morais. Assim, no ceticismo interno o plateau comum é a moralidade e não a metafísica. Em uma nota de rodapé ele esclarece a questão:

\begin{abstract}
"Um ponto de visa moral só pode ser prejudicado por um argumento moral. Assim o ceticismo que tememos é o ceticismo interior, e o argumento da causalidade ${ }^{69}$ não acarreta em si nenhum prejuízo. Sei que minhas opiniões seriam diferentes se eu tivesse vivido numa época muito diferente. Mas acho que minhas opiniões são melhores, $e$ também diferentes, e nenhuma explicação causal pode obrigar-me a abandonar esse ponto de vista, ainda que um argumento moral certamente pudesse fazê-lo." (ID: 105, nota 27).
\end{abstract}

Quando afirmamos que algo não é verdadeiro ou que não existe uma resposta para a questão, se falamos que a primeira é uma opinião moral, a segunda também o é. Como no ceticismo externo, não podemos afirmar o certo ou o errado, também não podemos dizer o mesmo sobre a segunda afirmação. Portanto, as afirmações acima são internas à moral. Isso é para confirmar que a interpretação não pode ser ameaçada pelo ceticismo externo.

\footnotetext{
${ }^{69} \mathrm{O}$ argumento da causalidade se refere a como as nossas crenças são formadas. Dado que elas são
} fruto da cultura, poderíamos questionar sua procedência ou mesmo dar força para o ceticismo externo. 
Portanto, o perigo está no ceticismo interno e precisamos mostrar como a interpretação trata dessa ameaça.

Um ponto fundamental é que não podemos ver a prática sem as lentes da moralidade. Os fatos que tratamos na primeira etapa pré-interpretativa estariam lá apenas por conta do seu status moral, eles são proposições morais na atitude interpretativa.

"Interpretation for Dworkin therefore represents something close to the end product of moralizing with others who are largely in agreement and who endorse true propositions of morality; that means his theory of law derives from direct moral proposals- of universal application - concerning equality and freedom”. Guest (2009:354)

Dworkin busca um “terreno comum” para a discussão dos temas, e faz isso nos levando para um patamar mais abstrato com o método interpretativo. Como se ele "limpasse o terreno" e deixasse apenas o essencial para que as partes numa disputa política pudessem argumentar com os mesmos parâmetros.

"The abstract nature of interpretation is appealing because it abstracts from the substantial arguments about what is the best interpretation and shows that two participants, offering rival interpretations, can have a plateau of agreement, namely that they are arguing about what amounts to the best interpretation." Guest (1997:24)

Mas então como devemos aplicar a interpretação na prática social como o direito?

\subsection{O Direito como Integridade e a Verdadeira Comunidade}

O conceito de direito para Dworkin foi construído juntamente com um conceito de comunidade, porque o direito como integridade nos diz que os direitos e deveres devem ser vistos como criados por um único autor, a comunidade personificada. Será 
da comunidade, das associações fraternais, que emergirão as obrigações e não de um acordo implícito sobre os princípios de justiça.

As teorias gerais do direito devem ser abstratas, já que sua finalidade é interpretar o ponto essencial e a estrutura da jurisdição e não uma parte específica dela. As interpretações construtivas sobre o direito vão mostrá-lo à sua melhor luz, para termos um equilíbrio entre a jurisdição atual e a melhor justificativa dessa prática. Assim, Dworkin sugere que a discussão sobre o direito se dá em como ele guia e restringe o poder do governo. Isso somente será permitido pelos direitos e responsabilidades individuais originários de decisões políticas anteriores, ou seja, a coerção é autorizada desde que façam parte de decisões anteriores do tipo adequado. Para o autor, essa é uma forma distinta de tratar o direito e a moral, já que busca estabelecer uma relação de justificação entre as decisões políticas anteriores e a coerção atual.

“(...) o direito de uma comunidade é o sistema de direitos e responsabilidades que respondem a esse complexo padrão: autorizam a coerção porque decorre de decisões anteriores do tipo adequado. São, portanto, direitos e responsabilidades jurídicas.” (ID: 116).

Essa seria a estrutura necessária para a interpretação do direito. É desse patamar comum mais abstrato do qual deveremos partir. Para Dworkin, uma concepção de direito vai utilizar alguma descrição de como as práticas jurídicas que, por sua vez, definem as decisões do passado, justificam a coerção do estado. Ainda, deve tentar responder por que há uma relação entre uma decisão do passado e sua obediência no futuro. Vê-se que o precedente jurídico ganha uma posição importante nessa atitude interpretativa. Uma concepção do direito não precisa justificar todas as práticas políticas, poderá inclusive dizer que algumas são incoerentes e não válidas. Essa avaliação poderá ser feita na etapa pós-interpretativa e exatamente nesta fase poderemos ter várias interpretações. Aqui, os casos difíceis seriam importantes para verificar a eficácia de cada interpretação. As questões que irão emergir durante a 
atitude interpretativa nos levarão para além do direito, até a moral política e a metafísica $^{70}$.

Em “O Império do Direito” temos 3 concepções de direito: o convencionalismo, o pragmatismo e o direito como integridade. Para fins desse trabalho, vamos discutir diretamente o que nos interessa. $\mathrm{O}$ direito como integridade se propõe a responder o que as demais teorias gerais não fazem: como os cidadãos devem se comportar e como os juízes devem decidir os $\operatorname{casos}^{71}$. Mas para discutirmos o direito como integridade precisamos definir dois conceitos: a integridade e a comunidade personificada.

Segundo Dworkin, na vida política real as pessoas atuam dentro de e sobre uma estrutura política e não como no caso de estados de natureza, no qual, a priori, não estamos comprometidos com nenhum governo ou constituição. Mas alguns ideais entre os dois modelos são compartilhados: a estrutura política imparcial, justa distribuição de recursos e oportunidades e um "processo equitativo de fazer vigorar as regras e os regulamentos que os estabelecem.”72 Estamos falando, respectivamente, de: equidade, justiça, e o “devido processo legal adjetivo”. Mas para ele falta tratar de outro conceito, a integridade política, ou seja, a idéia de que o estado tenha uma só voz e aja de forma coerente com seus cidadãos baseado-se em princípios, ou, de forma mais simplista, de que devemos tratar os casos semelhantes da mesma maneira. Nas três virtudes acima tal questão não é abordada. A integridade aparece como um ideal distinto da justiça e da equidade. Podemos respeitar o critério da integridade mesmo que tenhamos uma divergência sobre o que é justo.

A integridade está no centro de sua concepção do direito e é aplicada às demais virtudes, por exemplo, a integridade da concepção de justiça exige que os princípios

\footnotetext{
${ }^{70}$ ID: $125-26$.

${ }^{71}$ Dworkin diz que uma teoria do direito é composta de duas partes: a parte dos fundamentos do direito, que são as circunstâncias nas quais as proposições jurídicas são verdadeiras, e a força do direito, que é relativa ao poder que essas proposições verdadeiras têm em justificar a coerção. O direito como integridade se preocupa em tratar prioritariamente da força do direito. Uma teoria sobre os fundamentos do direito não assume uma posição sobre a utilização da força do direito.

${ }^{72}$ ID: 200.
} 
morais para justificar as decisões do legislativo sejam reconhecidos pelo restante do direito. A integridade também nos dá princípios mais práticos, como a integridade de legislação e de julgamento. Este último é que nos diz que o juiz deve ver o direito de forma integrada e não como uma colcha de retalhos, sem preocupações com o todo. A integridade na legislação pede que a criação do direito por legislação leve em conta a coerência com os princípios.

Segundo Dworkin, ao aceitarmos a integridade política como um ideal distinto, personificamos a comunidade. Esta estabelece relações com os três ideais acima, da mesma forma que nós, como membros dessa comunidade assumimos nossas conviç̧ões pessoais. Portanto, sem cair numa "metafísica ruim",73, a comunidade assumiria o papel de uma entidade especial distinta de seus membros, podendo obedecer ou não a seus princípios, agir com integridade ou não. No entanto, ela não estaria “descolada”, mas seria uma criação das práticas nas quais se inscreve.

Dworkin, portanto não assume que a comunidade é uma somatória de agentes que buscam seu auto-interesse. Ele se aproxima de uma noção comunitarista que dá valor ao coletivo. A comunidade dworkiana não é uma pessoa real, mas seu conceito está vinculado à relação complexa entre responsabilidades de cada um de seus membros e das autoridades. Um exemplo de personificação é o caso de uma empresa que é responsabilizada por um defeito num de seus produtos. Quem pode ser responsabilizado? Os acionistas? Cada um dos empregados que participaram do processo de produção? Deveremos avaliar a conduta moral de cada um dos envolvidos? Nesse caso, surge a figura da empresa como agente moral e responsável por seus erros. Por exemplo: o nazismo gerou um sentimento coletivo de vergonha e culpa dos alemães em relação aos judeus. Mesmo considerando que os alemães de hoje não foram responsáveis pelo holocausto, a responsabilidade coletiva existe porque os nazistas eram alemães. Mas isso não significa negligenciar as responsabilidades

\footnotetext{
${ }^{73}$ ID: 204.
} 
individuais. Aliás, essa responsabilidade individual faz parte dos princípios de dignidade que apóiam o princípio abstrato da igual consideração e respeito.

A questão é que não podemos exigir das autoridades de estado a mesma moral que exigimos de um indivíduo, porque há a necessidade do elemento da imparcialidade. Elas, diferente de nós, têm a obrigação de tratar a todos como iguais, e cada um com uma concepção de bem. Por isso, o autor afirma que, quando a imparcialidade das autoridades não é obedecida, estamos no terreno da corrupção ou improbidade. As autoridades não devem buscar atender às suas preferências, mas obedecer a um princípio abstrato da igualdade.

\begin{abstract}
“(...) compartilhamos o ponto de vista de que as nossas autoridades devem tratar como iguais todos os membros da comunidade que governam porque acreditamos que é assim, e não de outra maneira, que eles [as autoridades] devem comportar-se. Portanto, não podemos explicar as responsabilidades especiais da função política se tentarmos extraí-las diretamente de princípios correntes da moralidade privada. Precisamos de uma idéia que não se encontra ali: a de que a comunidade como um todo tem obrigações de imparcialidade para com os seus membros, e que as autoridades se comportam como agentes da comunidade ao exercerem essa responsabilidade. Aqui como no caso da empresa, precisamos tratar a responsabilidade coletiva como logicamente anterior às responsabilidades de cada uma das autoridades. (...) Ao aceitarmos que nossas autoridades agem em nome de uma comunidade na qual somos todos membros, tendo uma responsabilidade que portanto compartilhamos, isso reforça e sustenta o caráter de culpa coletiva, o sentimento de que devemos sentir vergonha e ultraje quando eles agem de modo injusto." (ID:212).
\end{abstract}

As nossas autoridades agem em nosso nome e têm como responsabilidade tratar a todos como iguais. Esta é a origem da virtude soberana do estado de tratar a todos com igual consideração e respeito.

A preocupação de Dworkin é mostrar que a integridade pode ser um ideal independente da justiça e da equidade ${ }^{74}$, sobretudo porque ela poderá ser o fiel da balança quando aqueles entrarem em conflito. Em prol da integridade poderemos optar por decisões injustas. O exemplo mais utilizado no ID é um caso difícil, o caso

\footnotetext{
${ }^{74}$ Como salienta no texto, essas são as virtudes que ele dá mais peso na discussão sobre integridade.
} 
McLoughlin que trata se uma senhora tem direito à indenização porque parentes próximos morreram num acidente e ela alega que, ao saber da notícia, sofreu danos emocionais e, por isso, deveria ter o direito a uma indenização. O detalhe é que ela estava em casa e não presenciou o acidente. Dados os precedentes de indenização nesses casos, pela integridade, a decisão poderia ser favorável a ela, mas podemos argumentar que, por uma questão de justiça, não caberia.

A integridade aparece como ideal independente porque não podemos aceitar que o Estado aja sem obediência aos princípios. Aqui a atenção é para as soluções conciliatórias $^{75}$, que de forma simplista, seriam aquelas tratadas caso a caso, sem uma preocupação com as conseqüências das mesmas para o direito e para a própria sociedade. Ainda, em soluções conciliatórias podemos ter casos semelhantes tratados distintamente, e isso nega o direito de ser tratado igualmente perante a lei. E não haveria razões de justiça e equidade para as rejeitarmos. A integridade, como ideal independente, rejeita a incoerência de princípio entre os atos do Estado. Um exemplo são as decisões num estado federado, que deve manter uma unidade nacional, mas respeitar a autonomia limitada outorgada aos estados.

A força da integridade está no conceito de comunidade personificada. Daí a complexidade do argumento de Dworkin. A comunidade que aceita a integridade como ideal independente se transforma numa forma especial de comunidade, um agente moral, já que ela promove sua autoridade moral para assumir o monopólio do poder coercitivo. Ainda, a integridade nos protege da parcialidade, da corrupção oficial e da fraude.

Mais importante é a interpretação sobre o conceito de direito, que nos traz uma nova forma de ver a relação entre os indivíduos e a comunidade, ponto de maior choque entre os liberais e os comunitaristas. Para estes, os liberais ignoram o papel da comunidade e trazem uma concepção de indivíduo independente, buscando seu auto-

\footnotetext{
${ }^{75}$ Segundo Dworkin, são "leis que mostram incoerência de princípio e que podem ser justificadas - se é que o podem - somente com base numa distribuição equitativa de poder político entre as diferentes facções morais”. ID: 217, nota 6.
} 
interesse, alheio a seu entorno social. Dworkin parece estar no "meio do caminho" entre liberais mais conservadores e os comunitaristas. Isso pode parecer para os liberais um falso liberalismo e para os comunitaristas, um liberalismo que se diz preocupado com a comunidade, mas que mantém seus pressupostos sobre o indivíduo. Na sua concepção de liberalismo, a comunidade liberal apresentada no livro "A Virtude Soberana" não parece tão bem fundamentada como no ID. Estamos antecipando uma discussão que será explorada adiante, mas é importante notar como a comunidade tem seu lugar na teoria do direito. Podemos usar o mesmo conceito? Qual a concepção de comunidade para Dworkin? Nosso argumento é que a concepção de comunidade de princípios de sua interpretação sobre o conceito de direito é compatível com o liberalismo abrangente e complementa o que ele define como comunidade liberal.

Voltando ao ponto, diante da integridade os cidadãos passam a compreender as normas de forma mais coesa e não como fruto de soluções negociadas para fins específicos. Os cidadãos precisam ver a legislação guiada por uma concepção pública de justiça, com compromisso.

\begin{abstract}
"A integridade, pelo contrário, insiste em que cada cidadão deve aceitar as exigências que lhe são feitas e pode fazer exigências aos outros, que compartilham e ampliam a dimensão moral de quaisquer decisões políticas explícitas. A integridade, portanto, promove a união da vida moral e política dos cidadãos: pede ao bom cidadão, ao decidir como tratar seu vizinho quando os interesses de ambos entram em conflito, que interprete a organização comum da justiça à qual estão comprometidos em virtude da cidadania. A integridade infunde às circunstâncias públicas e privadas o espírito de uma a outra, interpenetrando-as para o benefício de ambas." (ID: 230).
\end{abstract}

Essa relação implica uma noção de fidelidade a esse sistema de princípios, bem como de responsabilização ${ }^{76}$ diante do sistema de sua comunidade. Assim muda o próprio

\footnotetext{
${ }^{76}$ Dworkin usa um conceito de auto-legislação no qual seríamos autores das decisões tomadas pelas autoridades. Tal conceito precisa da idéia de integridade visto que, segundo ele, ninguém referendaria um sistema que não respeita a coerência de princípios.
} 
conceito de obrigação política como trataremos posteriormente. Dworkin não fala nestes termos, mas a integridade evidencia limites para a atuação dos cidadãos, legisladores e juízes. Se o método interpretativo adota a continuidade entre ética e moralidade, a integridade como ideal político parece exercer o equilíbrio fundamental entre o que é interesse próprio e os interesses da comunidade. No seguinte sentido: a aceitação viria não da exclusão das doutrinas abrangentes, mas justamente porque elas estariam presentes.

Mas a integridade apenas é um conceito suficiente para a justificação da coerção do Estado? Entramos no tema importante que é a questão da legitimidade e das obrigações políticas. A legitimidade do Estado, de exercer o poder coercitivo e as obrigações morais provenientes das decisões, são questões distintas.

O direito precisa de uma justificação para o exercício do poder coercitivo do Estado. Este precisa ter legitimidade e seus cidadãos devem obedecer à coerção que lhes é imposta. Portanto, o Estado é legítimo quando suas práticas constitucionais e estrutura são aquelas que geram obrigações junto aos cidadãos de tal sorte que eles obedeçam às decisões políticas que impõem deveres. A hipótese de Dworkin é que o Estado que aceita a integridade tem um argumento melhor em favor da legitimidade.

Mas temos algumas alternativas para discutir a legitimidade, uma delas é dada pelo uso do contrato social. Ele estabelece, de comum acordo, como os cidadãos apoiariam as instituições públicas. Dworkin afirma que o dever de apoiar as instituições justas, que passaram pela posição original não têm a legitimidade necessária, pois não ofereceria uma ligação estreita entre obrigação política e a comunidade, ou "não mostra por que os ingleses têm o dever especial de apoiar as instituições da Inglaterra” (ID: 234). Segundo Rawls, as pessoas reconheceriam esse dever natural de apoiar as instituições que passam pelos testes de justiça. Mas ele falha em nos mostrar por que as pessoas têm uma obrigação política para com aquelas instituições. 
As obrigações políticas podem ser vistas como obrigações associativas ou comunitárias? Estas são responsabilidades especiais que temos por pertencer a algum, grupo, família, ou nação. Estes grupos, por sua vez, não são definidos por decreto, pela própria atitude interpretativa. Nesse exercício, Dworkin afirma que não conseguimos ir adiante se considerarmos que as obrigações são provenientes de escolhas. A amizade, por exemplo, acaba por se formar com eventos e atitudes que nem sempre são percebidas. As obrigações que são frutos de uma "história de eventos e atos que atraem obrigações, e raramente nos damos conta de estar assumindo um status especial à medida que a história se desenrola."77 (ID: 239).

Se a escolha não faz sentido, onde vamos sustentar o dever natural de honrar essas responsabilidades especiais? Vamos fazê-lo num conceito mais abstrato de reciprocidade, que precisará das idéias de integridade e interpretação.

Não precisamos compartilhar exatamente todas as responsabilidades, basta uma "idéia geral e difusa dos direitos e das responsabilidades especiais que os membros devem pôr em prática entre si, uma idéia do tipo e do nível de sacrifício que suas relações mútuas devem pressupor.” (ID: 241).

Para que as responsabilidades especiais sejam vistas como verdadeiras obrigações associativas (ou fraternais) devem atender a quatro condições:

1. As obrigações do grupo são especiais porque são devidas aos seus membros e não a pessoas que não pertençam a ele;

2. As responsabilidades são pessoais, ou seja, vão de um membro a outro;

3. As responsabilidades são decorrentes de uma responsabilidade mais geral, o interesse geral de cada membro pelo bem-estar dos demais. O interesse vai

\footnotetext{
${ }^{77}$ As relações familiares entre pais e filhos, entre irmãos não dão menor chance de escolha ainda, o que não elimina as obrigações associativas entre eles.
} 
variar de acordo com as relações que mantivermos: como filhos, como amigos, como chefe etc.;

4. Os membros devem pressupor que as práticas do grupo mostram igual interesse por todos os membros, ou seja, essas associações fraternais são igualitárias.

A esse tipo de responsabilidade denominamos "obrigações fraternais", porque são aquelas ligadas à verdadeira comunidade.

"As responsabilidades que uma verdadeira comunidade mobiliza são especiais $e$ individualizadas, e revelam um abrangente interesse mútuo que se ajusta a uma concepção plausível de igual interesse." (ID: 243).

Uma verdadeira comunidade deve ser também uma comunidade básica, ou seja, deve satisfazer às condições geográficas, genéticas ou históricas identificadas pela prática social $^{78}$. Significa que uma verdadeira comunidade não pode forçar uma pessoa a ser membro dessa comunidade se não atender aos requisitos de uma comunidade básica. As pessoas não podem ser forçadas a serem membros de uma comunidade involuntariamente. Mas existem diferentes formas de tratamento entre os membros de uma comunidade. Dworkin nos apresenta três delas:

1. o modelo de fato, os membros da comunidade tratam sua associação apenas como um acidente de fato da história e da geografia, como uma comunidade associativa que nada tem de verdadeira;

2. o modelo das regras - os membros de uma comunidade política aceitam o compromisso geral de obedecer a regras estabelecidas de um certo modo que é específico dessa comunidade. Como se fosse um contrato. A concepção

\footnotetext{
${ }^{78}$ Brown (2009) afirma que essa definição de verdadeira comunidade limitaria a aplicação da teoria de justiça de Dworkin entre nações afinal, o compromisso das obrigações fraternais se dá somente entre os membros daquela comunidade. $\mathrm{O}$ autor tenta contornar essas limitações e apresentar a igualdade de recursos como uma alternativa para a justiça distributiva entre as nações.
} 
convencionalista do direito é a companheira natural desse modelo de comunidade. O convencionalismo se ajusta às pessoas que tentam promover sua própria concepção de justiça e equidade, através da negociação e acordo.

3. o modelo de princípios - as pessoas são membros de uma comunidade política genuína apenas quando aceitam que seus destinos são fortemente ligados da seguinte maneira: aceitam que são governadas por princípios comuns, e não apenas por regras criadas por um acordo político;

Pelo que foi apresentado anteriormente, podemos afirmar que para a interpretação de Dworkin, o modelo de princípios é o que melhor se encaixa. As regras são insuficientes para explicar a relação entre seus membros, pois estes são governados por princípios comuns. São governados por um sistema coerente de princípios e não apenas por decisões particularistas. Portanto, aceitam que a integridade é um ideal político e sua aceitação é um dos componentes da comunidade política.

Dentre os três modelos de comunidade, precisamos saber qual atende às quatro condições para ser uma verdadeira comunidade. $\mathrm{O}$ modelo de fato pode ser facilmente descartado porque seus membros não se interessam pelos demais. O modelo de regras deve ser descartado porque os membros podem se comportar de maneira egoísta, visto que suas obrigações se encerram com o conteúdo das regras. Estamos buscando uma relação que transcende a formalidade. O ideal de justiça e de equidade não são suficientes para definir essa comunidade. A preocupação de Dworkin é com a forma do interesse mútuo que as práticas políticas geram. Numa comunidade de princípios, as pessoas aceitam que são governadas por princípios comuns e não apenas por regras.

"Para tais pessoas, a política tem uma natureza diferente. É uma arena de debates sobre quais princípios a comunidade deve adotar como sistema, que concepção deve ter de justiça, equidade e justo processo legal e não a imagem diferente, apropriada a outros modelos, na qual cada pessoa tenta fazer valer suas convicções no mais vasto território de poder ou de regras possível.” (ID:254). 
Cada membro, portanto, aceita a integridade como ideal distinto, mesmo que esteja em desacordo sobre a moral política. Por isso, a comunidade de princípios satisfaz as condições de uma verdadeira comunidade. O interesse é genuíno, exige da integridade que cada um deve ser tratado com o mesmo interesse. Essa comunidade não é automaticamente justa, mas é aquele modelo que satisfaz as condições da verdadeira comunidade melhor do que qualquer outro modelo no qual as pessoas divergem sobre o conceito de justiça e equidade, ou seja, é adequada para uma sociedade plural. É preciso “engajamento” para que a comunidade política seja uma verdadeira comunidade, para que o direito desenvolva, seja alterado, interpretado de forma global e fundado em princípios. Se pensarmos em indivíduos atomizados que pensam apenas no auto-interesse, não faz sentido falar numa comunidade de princípios.

"Se podemos entender nossas práticas como apropriadas ao modelo de princípios, podemos sustentar a legitimidade de nossas instituições, e as obrigações políticas que elas pressupõem, como uma questão de fraternidade, e deveríamos portanto tentar aperfeiçoar nossas instituições em tal direção.” (ID: 258).

A comunidade que aceita a integridade apresenta a melhor defesa da legitimidade política. Torna as obrigações políticas um tipo de obrigação associativa sem cair no erro de pensar que as relações entre as pessoas devam envolver sentimentos que temos com familiares e amigos. A comunidade é política e seus laços são estabelecidos por uma noção moral de que ela é uma entidade especial baseada em princípios. Sem essa noção de sistema de princípios, os membros não estabelecerão um interesse mútuo genuíno para além de regras.

Finalmente, após um longo argumento sobre o conceito de comunidade e a tentativa de mostrar que a integridade é um ideal distinto, Dworkin afirma que a integridade é a melhor interpretação construtiva das práticas jurídicas.

Mas a integridade nas decisões jurídicas não é apenas coerência, ou seja, decidir casos semelhantes da mesma forma. Dada sua exigência, o juiz precisa ser mais abrangente para alcançar a coerência com os demais princípios. 
"A integridade exige que as normas públicas da comunidade sejam criadas e vistas na medida do possível, de modo a expressar um sistema único e coerente de justiça e equidade na correta proporção. Uma instituição que aceite esse ideal às vezes irá, por essa razão, afastar-se da estrita linha das decisões anteriores, em busca de fidelidade aos princípios concebidos como mais fundamentais a esse sistema como um todo.” (ID: 264).

O Estado que aceita a integridade deve ter uma só voz quando se manifestar sobre a natureza dos direitos mais fundamentais. O direito como integridade é a melhor interpretação construtiva, assim os juízes passam a vê-lo como criado por um único autor, a nossa comunidade personificada. Diferente das demais concepções, no direito como integridade, os juízes continuam seu processo interpretativo mesmo depois de proferida a decisão. O mesmo material interpretado deverá continuar a sê-lo. Uma comparação útil que Dworkin faz é do direito com a literatura, na qual afirma que o primeiro pode ser visto como um romance em cadeia. O juiz deve interpretar o direito, imaginando que é um romance escrito por vários autores, à medida que a história se desenrola mais limitada vai ficando a sua liberdade. Mas, mesmo assim, o juiz poderá dar a sua contribuição. Essa é uma maneira de ver o direito de forma integrada e ampla. Para Dworkin, a interpretação oferecida “deve fluir ao longo de todo o texto” e “possuir um poder explicativo geral”79. A interpretação tem duas dimensões, a da adequação e a que exige que julguemos quais das leituras de ajusta melhor à obra em desenvolvimento.

\footnotetext{
"O direito como integridade pede que os juízes admitam, na medida do possível, que o direito é estruturado por um conjunto coerente de princípios sobre a justiça, a equidade e o devido processo legal adjetivo, e pede-lhes que os apliquem nos novos casos que se lhes apresentem, de tal modo que a situação de cada pessoa seja justa e equitativa segundo as mesmas normas.” (ID:291).
} 
O direito como integridade responde que os fundamentos do direito estão na integridade, na melhor interpretação construtiva das decisões jurídicas do passado e se aplica aos casos difíceis.

\begin{abstract}
"Aceitamos a integridade como um ideal político porque queremos tratar nossa comunidade política como uma comunidade de princípios, e os cidadãos de uma comunidade de princípios não têm por único objetivo princípios comuns, como se a uniformidade fosse tudo que desejassem, mas os melhores princípios comuns que a política seja capaz de encontrar. A integridade é diferente da justiça e da equidade, mas está ligada a elas da seguinte maneira: a integridade só faz sentido entre as pessoas que querem também justiça e equidade." (ID: 314).
\end{abstract}

Portanto, a interpretação construtiva nos apresentou a integridade como um ideal político complementar à justiça e à equidade, e mais importante, a uma concepção de comunidade que poderemos integrar com as concepções de igualdade e liberdade que discutiremos a seguir. Evidentemente, nossa discussão não é sobre o direito, mas no seu método interpretativo construtivo e na definição de comunidade personificada. No ID ele fala sobre o conceito de liberalismo que defende e questiona a noção de que as pessoas sob o liberalismo não se importam com as demais.

Nos capítulos seguintes vamos discutir a interpretação de Dworkin para o liberalismo abrangente, chamado de igualdade liberal. Mais importante, veremos como sua obra apresenta uma unidade de pensamento sobre o papel da filosofia política. Assim como em Rawls, a obra está sujeita às mais variadas e contundentes críticas, no entanto, é fundamental "juntar as pontas” da argumentação dworkiana para conhecer suas origens. Dworkin não é apenas um liberal igualitário que usa como métrica a igualdade de recursos, ele nos apresenta uma nova forma de interpretar e defender o liberalismo, considerando como direito fundamental que todos devem ser tratados com igual consideração e respeito. 


\title{
1.4 Por onde começamos a interpretação? O Plateau Igualitário
}

Já apresentamos a forma como devemos tratar os conceitos políticos, agora vamos apresentar a idéia mais abstrata a partir da qual Dworkin interpreta os conceitos de igualdade, liberdade e comunidade para compor o que ele chama de igualdade liberal.

A virtude soberana do Estado é tratar a todos com igual consideração e respeito e a versão de liberalismo defendida pelo autor assume que a liberdade, igualdade e a comunidade não são virtudes políticas distintas, mas aspectos de um único ideal político. Não há como compreendê-las de forma independente. A essas virtudes ele chama de "tecido emocional do liberalismo" ${ }^{\text {"80 }}$.

Mas de onde ele extrai esse princípio mais abstrato e por que precisamos partir dele para tratarmos daqueles conceitos?

Em LDS, Dworkin menciona pela primeira vez a idéia de que as pessoas têm o direito de serem tratadas com igual consideração e respeito. Para ele, grande parte das diferentes teorias políticas são interpretações desse direito. Por isso, chamou-o de "a kind of plateau in political argument”81. Essa é uma tentativa de encontrar um terreno comum que as pessoas possam compartilhar.

\begin{abstract}
“(...) the common ground we need in order to sustain a genuine largescale argument about what divides us cannot be found in principles of that level of concreteness. We must look much further back; we must look not to principles that are distinctly political or even moral but rather to principles that identify more abstract value in the human situation.” Dworkin (2006b:9).
\end{abstract}

A partir dessa idéia mais abstrata é que devemos buscar a sua melhor interpretação. Esse solo comum para a análise das diferentes interpretações é uma oportunidade de

\footnotetext{
${ }^{80}$ VS:331.

${ }^{81}$ Dworkin (1983c:25).
} 
discussão interna ao campo da filosofia política. Como se estivessem falando a mesma língua de forma a compreender um ao outro, libertarianos, utilitaristas e liberais igualitários $^{82}$. Dworkin, assim como Rawls, se coloca como autor de uma versão do que é tratar a todos com igual consideração e respeito.

Vamos entender melhor em quais circunstâncias devemos tratar a todos com igual consideração e respeito. Estamos no campo da política, das relações com as instituições e autoridades de Estado. Esse princípio não se aplica da mesma forma para nossos amigos, parentes e desconhecidos. No entanto, estamos falando de esferas avaliativas distintas, do privado e do público. É na esfera pública, de nossa relação com o Estado, que o princípio de tratar a todos sob seu domínio com igual consideração e respeito precisa ser obedecido. ${ }^{83}$ Um Estado legítimo é aquele que trata a , sob seu domínio, com igual consideração e respeito.

"A legitimate government must treat all those over whom it claims
dominion not just with a measure of concern but with equal concern. I
mean that it must act as if the impact of its policies on the life of any
citizen is equally important. On this account political legitimacy is not
an all-or-nothing matter but a matter of degree". Dworkin
(2006b:97). Portanto, o conceito de verdadeira comunidade política somente é legítimo se tratar a todos com igual consideração e respeito. Em trabalhos mais recentes, Dworkin toma como common ground os dois princípios de dignidade ${ }^{84}$ para discutir temas que dividem a sociedade norte-americana: ensino religioso, aborto, impostos. Ele não explicita a forma na qual esses dois princípios se relacionam com o da igual consideração e tão pouco porque eles ganham mais peso nesses textos mais recentes. Apenas afirma que os princípios de dignidade são aceitos por uma sociedade como a americana, foco de sua análise. Podemos dizer que eles complementam o que ele entende de common ground para a interpretação dos conceitos normativos. Na

\footnotetext{
82 Brown (2009), capítulo 4.

${ }^{83}$ Dworkin (2006b:94-5).

${ }^{84}$ Ver capítulo 1 de Dworkin (2006b). Em VS, Dworkin chama de princípios do individualismo ético.
} 
discussão sobre a igualdade de recursos, sua maior queixa é que as teorias alternativas não aprofundam a questão da responsabilidade pessoal pelas escolhas. A concepção do liberalismo abrangente, ao contrário, não pode abrir mão dos dois conceitos de dignidade.

Esses dois princípios também dominam a resposta ao desafio da igual consideração, uma teoria liberal abrangente.

O primeiro princípio é o da igual importância ou o princípio do valor intrínseco ${ }^{85}$ e o segundo é o da responsabilidade especial. O princípio do valor intrínseco nos diz que a vida humana tem um tipo especial de valor objetivo. Seu valor está ligado a uma potencialidade a partir do momento em que nascemos, ou seja, o valor objetivo está ligado ao fato de que a vida humana é importante por si e não apenas porque queremos que seja um sucesso. Todos nós temos uma razão para querer o sucesso da vida e outra para lamentar se ela falhar.

O segundo princípio da responsabilidade especial afirma que cada um de nós é responsável pelo sucesso de nossa vida. Essa responsabilidade incluiria também a nossa convicção sobre que tipo de vida seria boa para nós. Significa que ninguém ou quaisquer instituições podem impor um modelo de vida a ser seguido sem o nosso consentimento.

Os dois princípios definem, segundo Dworkin, as bases e as condições da dignidade humana, por isso são chamados de princípios de dignidade. Esses princípios são suficientemente gerais para ocuparem o posto de terreno comum para uma disputa política entre diferentes interpretações. Esses princípios podem ser acusados de individualistas, mas Dworkin não aceita a idéia de que a vida de uma pessoa pode ser

\footnotetext{
${ }^{85}$ Em VS, Dworkin usa a primeira denominação, mas em “Is Democracy is Possible Here?” passa a chamar de principle of intrinsic value. Isso porque está incorporando a idéia de que é possível ter um valor objetivo desenvolvido em Dworkin (1996). Também neste livro os dois princípios do individualismo ético passam a ser denominados princípios de dignidade, tomando forma para a construção de uma unidade entre ética e moralidade.
} 
concebida independentemente da sua comunidade ou tradição a qual pertence ${ }^{86}$. Esses princípios também não apóiam a noção de que a responsabilidade em identificar o tipo de vida que desejamos exige que neguemos os valores da comunidade. Veremos na exposição sobre a comunidade o papel fundamental que ela exerce na defesa de valores políticos como a igualdade e a liberdade e como é compatível com eles.

Os dois princípios de dignidade nos remetem àqueles dois valores políticos: a igualdade e a liberdade. O primeiro nos remete à igualdade e o segundo à liberdade. Aqui Dworkin já antecipa que sua concepção de igualdade, a igualdade de recursos, não entra em conflito com a liberdade.

"I do not accept this supposed conflict between equality and liberty; I think instead that political communities must find an understanding of each of these virtues that shows them as compatible, indeed that shows each as an aspect of the other. That is my ambition for the two principles of human dignity as well.” Dworkin (2006b:11).

Dworkin desenvolve com o princípio do valor intrínseco sua tese de que as pessoas com diferentes concepções de boa vida aceitam que é objetivamente importante como sua vida é vivida, e que a maioria das pessoas não tem razão para pensar que sua vida é menos importante que a dos demais. Não somente tem valor objetivo, mas que é igualmente valiosa. Significa que queremos uma boa vida, nos importamos com isso e que esse "padrão de qualidade" de uma vida é objetivo e não subjetivo. Mas o que significa subjetivo? Significa dizer que não existem fatos objetivos que tornam a vida boa, mas haveria apenas projeções de nossas emoções. Essa tese é defendida pelos céticos ou por teorias arquimedianas de justificação moral.

As pessoas se importam se sua vida é bem vivida porque esta tem um valor objetivo e não é uma projeção de nossas emoções. Quem não se importa com sua vida comete um atentado à dignidade.

\footnotetext{
${ }^{86}$ Na sua concepção de comunidade, o autor avalia a importância da mesma para o florescimento e sucesso da vida de seus membros. Ver mais em VS, cap. 5 e em ID, cap. 6.
} 
Se aceitarmos o primeiro princípio devemos também aceitar que o sucesso da vida das outras pessoas é igualmente importante, visto que não temos julgamentos que nos leve a uma conclusão distinta. Da avaliação que fazemos sobre a nossa vida, estamos caminhando para considerar que as demais vidas também são igualmente importantes. Isso traz conseqüências políticas e morais fundamentais. $\mathrm{Na}$ atualidade, uma das grandes tragédias humanas é justamente a menor importância que damos pelas vidas das outras pessoas. Para Dworkin, não podemos separar o auto-respeito (pelas nossas vidas) do respeito pela vida dos outros.

\begin{abstract}
“ (...) as I am now supposing you think, that objective importance cannot be thought to belong to any human life without belonging equally to all, then it is impossible to separate self-respect from respect for the importance of the lives of others. You cannot act in a way that denies the intrinsic importance of any human life without an insult to your own dignity. That point is a familiar insight in moral philosophy. It is at the center of Immanuel Kant's claim that respect for our own humanity means respect for humanity as such; Kant insisted that if you treat others as mere means whose lives have no intrinsic importance, then you are despising your own life as well." Dworkin (2006b:16-7).
\end{abstract}

Mostrar respeito pelos demais assim como conosco pode revelar as bases para a continuidade entre ética e a moralidade. Esse princípio de igualdade ajudará nosso autor a buscar a melhor interpretação para justiça, igualdade e liberdade. Mas Dworkin tem uma preocupação importante: o princípio do valor intrínseco não pode nos levar a pensar que existe um modelo de boa vida e que esse modelo deve ser seguido por todos nós. Isso violaria o princípio de tolerância ou da neutralidade do Estado em relação às concepções de boa vida. Por isso, o princípio da responsabilidade especial tem um papel relevante. De acordo com ele, temos responsabilidade pelo sucesso de nossa vida e isso significa também que nós devemos ser responsáveis pelas nossas decisões, ou seja, cada indivíduo vai escolher seu plano de vida racional ${ }^{87}$. Portanto, o

\footnotetext{
${ }^{87}$ A idéia de plano de vida racional na justiça como equidade assume uma série de pressupostos em relação à pessoa. Aqui apenas tomamos emprestada a noção de um plano de vida a ser seguido pelos indivíduos.
} 
segundo princípio condena quaisquer imposições sobre como devemos levar a nossa vida $^{88}$.

Mas aqui estamos falando de decisões pessoais como escolha de uma profissão, quando e para onde viajar: decisões sobre relações de propriedade, regras de trânsito, quanto devemos pagar de imposto de renda, etc são decisões de responsabilidade do Estado. Nosso dever é obedecê-las. Essa diferença entre decisões é a diferença entre a ética e a moralidade:

\begin{abstract}
"Our ethical convictions define what we should count as a good life for ourselves; our moral principles define our obligations and responsibilities to other people. The principle of personal responsibility allows the state to force us to live in accordance with collective decisions of moral principle, but it forbids the state to dictate ethical convictions in that way.” Dworkin (2006b:21).
\end{abstract}

Para Dworkin, assumindo esses dois princípios estamos definindo um terreno comum para tratarmos dos conflitos que sempre existem na vida política. Quando as controvérsias são travadas em “mundos completamente diferentes”, chegar a um acordo ou consenso pode ser impossível. Sobre esse ponto Brown (2009) apresenta uma abordagem importante. Ele diz que o que realmente importa para o debate político são os dois princípios de dignidade e não nossa aceitação do princípio abstrato da igual consideração e respeito. Mas essa conclusão pode estar ligada ao seu projeto de aplicar da teoria de Dworkin para uma justiça global. O direito abstrato de igual consideração e respeito está atado ao conceito de comunidade, ou seja, apenas os membros da comunidade teriam esse direito.

Os princípios que servem de base para um liberalismo mais abrangente abrem a possibilidade de uma continuidade entre a ética e a moralidade nos levando a um

\footnotetext{
${ }^{88}$ Dworkin (2006b) faz uma rápida análise sobre o papel da cultura no processo de decisão dos indivíduos alertando que cultura não é subordinação e que não resolvemos o que fazer de nossas vidas apenas com nossos próprios recursos, como seres isolados de qualquer influência. Outro ponto é o papel da religião, que para o autor é absolutamente tolerável e não significa violação de direitos. A tolerância religiosa seria mais uma virtude do Estado liberal: "Personal responsability does not mean scientism or even rationalism.” Dworkin (2006b:19).
} 
“equilíbrio” mais amplo. Na passagem a seguir podemos entender como o equilíbrio de sua teoria seria mais abrangente do que o “equilíbrio reflexivo” de Rawls:

\begin{abstract}
"Political philosophy that aims better to understand the political values must fold its own work into a large structure. It must aim, first to construct conceptions or interpretations to each of these values that reinforce the others - a conception of democracy, for example, that serves equality and liberty, and conceptions of each of these other values that serves democracy so understood. It must aim to construct these political conceptions, moreover, as part of an even more inclusive structure of value that connects the political structure not only to morality more generally but to ethics as well. (...) My recommendation is similar to Rawls's method of reflective equilibrium, which aims to bring our intuitions and theories about justice into line with one another. The difference with Rawls's methodology is more striking than the similarities, however, because the equilibrium I believe philosophy must seek is not limited, as his is, to the constitutional essentials of politics, but embraces what he calls a "comprehensive" theory that includes personal morality and ethics as well. If political philosophy is not comprehensive in its ambition it fails to redeem the crucial insight that political values are integrated, not detached." Dworkin (2006a: 161).
\end{abstract}

A igualdade liberal ou o liberalismo abrangente é um exemplo da sua interpretação de igualdade. A interpretação é holística na sua estrutura, por isso é o método que o autor considera essencial. Somente com a interpretação poderemos tratar os conceitos políticos um sob a luz dos outros, sem hierarquizá-los, mas dispô-los na forma de uma “abóbada",

89 “Geodesic dome” em Dworkin (2006a:160). 


\section{Capítulo 2 \\ O Liberalismo Abrangente de Dworkin}

As bases do que estamos chamando de "liberalismo abrangente" de Dworkin é sua versão de liberalismo, denominada "igualdade liberal” que foram apresentadas no seu texto “Foundations of Liberal Equality” (FLE), de 1988 e, bem antes, em "Liberalism” de 1978. A proposta de igualdade de recursos que ele desenvolve no início dos anos 80, passa a fazer parte do seu livro mais recente, A Virtude Soberana, que reúne sua teoria de justiça distributiva e uma versão de liberalismo que integraria a igualdade, liberdade e comunidade. Seu projeto unificador tem como um dos objetivos mostrar que aqueles conceitos não entram em conflito e que devemos buscar uma continuidade entre a ética e a moralidade para encontrarmos um terreno comum para o debate. Esta continuidade não é incompatível com a tolerância liberal, mas, ao contrário, seria sua melhor interpretação.

John Rawls buscou apresentar uma teoria da justiça alternativa ao intuicionismo e ao utilitarismo, este último visão filosófica influente que, segundo ele, deveria ser questionada. Sua teoria passou a ser chamada de "liberalismo igualitário”, concepção que sofrerá mudanças ao longo da produção intelectual de Rawls. Ele afirma que a sua teoria tem limitações, porque se aplica apenas ao que ele vai chamar de "estrutura básica da sociedade”. Essa estrutura básica reúne as instituições políticas e sociais juntas num sistema de cooperação social, com direitos e deveres básicos e regula a divisão das vantagens que aparecem da cooperação social ao longo do tempo. Ela não foi concebida para outra estrutura, como a família, fonte histórica de desigualdades.

Para Rawls, era preciso encontrar uma alternativa teórica e objetiva para definir critérios de justiça. As teorias intuicionistas apelam para “as nossas intuições” a fim de escolher o critério de justiça mais adequado. Elas podem estar alicerçadas em qualquer arcabouço ético presente, ou ainda em ideologias e religiões. Claramente, para os 
liberais, elas não se apresentam como solução para encontrarmos uma métrica para definir que critério nos leva a resultados mais justos. Mas será o utilitarismo que tomará conta dos esforços de Rawls na TJ.

Para Rawls, os dois princípios de justiça escolhidos por pessoas racionais, livres e iguais, sob o "véu de ignorância”, serão aceitos por uma sociedade plural com as mais diversas concepções de boa vida. É a definição da “posição original”, ou seja, a situação hipotética na qual as pessoas escolhem os princípios de justiça sem qualquer informação relevante como sexo, habilidade, características físicas, emocionais que possam influenciar a decisão das partes naquela situação hipotética. Por isso podemos afirmar que as partes naquela situação são conservadoras, ou seja, elas querem tornar a pior posição a melhor. Rawls recupera a tradição contratualista, a partir da posição original, e as partes estabelecem um acordo em torno dos princípios de justiça escolhidos.

Será justamente o contrato que Dworkin vai questionar como forma de garantir o estabelecimento e obediência aos princípios numa sociedade plural, respeitando a neutralidade do estado em relação às concepções de boa vida. As partes no contrato não têm informação alguma sobre seus talentos, preferências, status social e não têm o pressuposto de justiça a priori, apenas querem tornar a pior das posições na escala social a melhor possível.

O utilitarismo ou welfarismo diz que todo ato é moralmente correto se produzir mais felicidade ou bem-estar para os membros da sociedade. As teorias da justiça rawlsiana e dworkiana foram construídas como concepções de justiça que não estivessem presas justamente a conceitos de dor ou prazer ou a concepções religiosas, morais e filosóficas ${ }^{90}$.

\footnotetext{
${ }^{90}$ Essa afirmação será feita em Justice as Fairness: a restatement, porque Rawls considerou que não havia deixado isso claro nas edições de A Theory of Justice.
} 
A partir de Rawls vários autores passam a apresentar “novas teorias de justiça” ou com diferentes equalizanda ${ }^{91}$, ou seja, o que deveria ser igualado. Em Rawls deveríamos ter a igualdade dos bens primários, em Amartya Sen, a igualdade de capacidades e em Ronald Dworkin, a igualdade de recursos. Além destes, temos os libertarianos (Nozick), comunitaristas (Kymlicka, Taylor), pluralistas (Waltzer) etc. Qualquer intelectual que busque compreender o debate na filosofia política normativa irá, de alguma forma, se deparar com essas diferentes visões do que é justo ou o que deve ser igualado.

Dworkin, como já assinalamos, é classificado como um liberal igualitário seguindo a tradição de Rawls, mas ele apresenta uma concepção de liberalismo, a igualdade liberal, que conciliaria duas virtudes aparentemente em conflito, a liberdade e a igualdade, que também aparece como um objetivo da TJ, além da continuidade da moralidade e as nossas concepções de boa vida. Isso significa que Dworkin não apresenta apenas uma nova métrica, os recursos no lugar dos bens primários, mas um liberalismo abrangente $^{92}$ que assume a continuidade entre a ética e a moralidade. Dworkin emprega o que ele chama de “estratégia de continuidade” para mostrar que nossas convicções éticas pessoais não estão separadas das nossas concepções políticas, como os liberais desde Locke assumem, e isso nos levaria a um liberalismo sem o trade-off de igualdade e liberdade, já que uma virtude não poderá ser definida sem a outra. Acrescenta que não faz sentido considerar as concepções de boa vida separadas das nossas concepções políticas se o objetivo for uma sociedade justa.

A crítica interna que Dworkin faz ao liberalismo tornaria este mais fortalecido ante a crítica dos comunitaristas ${ }^{93}$, principais críticos dos liberais igualitários, bem como

\footnotetext{
${ }^{91}$ Significa aquilo que deve ser igualado. Ver Cohen (1989) sobre tipos de equalizandum.

92 Rawls utiliza o conceito de liberalismo abrangente no Liberalismo Político justamente para diferenciar de sua versão que exclui as doutrinas abrangentes.

93 A igualdade liberal de Dworkin apresentará a neutralidade não como um axioma, mas a qual chegamos de forma natural dada a estratégia que ele propõe. Essa é uma das críticas dos comunitaristas de fazer a conexão entre a auto-determinação, ou seja, o que vamos fazer da nossa vida e a neutralidade do Estado em relação a esta escolha. Sobre as concepções de boa vida e a relação com a ética, outro autor importante para a discussão é Charles Taylor que, ao contrário de Sandel ou
} 
diante daqueles que consideram o liberalismo insuficientemente comprometido com a igualdade. O seu liberalismo, ao contrário, se diz baseado na igualdade.

Precisamos compreender primeiro o que Dworkin entende por liberalismo e por que é necessário pensar numa nova versão ${ }^{94}$. A preocupação do autor é mostrar que o liberalismo é uma teoria moral na qual a igualdade e a liberdade são virtudes de um mesmo ideal político e que não estariam em conflito. Podemos entender o liberalismo como uma doutrina que tem como princípio a neutralidade do Estado em relação às nossas concepções de boa vida ou tolerância. Isso significa dizer que o Estado não deverá estabelecer direitos e deveres de acordo, por exemplo, com nossa orientação sexual ou dieta alimentar. Assim, ser homossexual não poderá ser considerado crime, assim como ser vegetariano.

Em O Império do Direito quando Dworkin discute a personificação da comunidade, como uma entidade especial, mas não metafísica, define o lugar das nossas concepções pessoais, da comunidade e como devemos buscar uma conciliação entre esses conceitos.

“Cada um de nós defende um ponto de vista pessoal, ambições e
compromissos próprios que temos liberdade de perseguir, livres das
reivindicações dos outros por igual atenção, interesse e recursos.
Insistimos em uma esfera de soberania moral individual dentro da
qual cada um pode preferir os interesses da família e dos amigos,
dedicando-se a projetos egoístas, ainda que grandiosos. Qualquer
concepção de justiça no comportamento pessoal, qualquer teoria
sobre o modo como a pessoa justa se comporta com relação aos
outros, limitará essa esfera da soberania pessoal, mas nenhuma
concepção aceitável à maioria de nós será capaz de eliminá-la por
inteiro.” (ID, 211).

MacIntyre, não nega por completo o liberalismo. Taylor afirma que os seres humanos não podem ser interpretados sem considerar sua concepção de boa vida derivada da comunidade. Diferente de Kant, o "eu" para Taylor está inserido e não separado da comunidade.

${ }^{94}$ Ver Dworkin, (1983a) "What Liberalism Isn't”, NYRB, vol. 29; Dworkin (1983b) "Why Liberals Should Believe in Equality”, NYRB, vol. 30 e "O Liberalismo” em QP. 
Mas o que o liberalismo tem a ver com igualdade? O liberalismo ungido pela Revolução Francesa estabelecia igualdade, liberdade e fraternidade como direitos dos homens contra a tirania do Rei. O Estado secular daria lugar ao Estado tolerante. A pobreza $^{95}$ passa a ser vista de outra forma, não como o destino dos pecadores, mas como injustiça. Rousseau, que influenciou os revolucionários franceses e assim como Kant, que, por sua vez, influenciou Rawls e Dworkin, coloca, nas mãos dos cidadãos, o dever de resolver os problemas da sociedade e a solução estaria na política e não na religião ou filosofia. Mais ainda, a desigualdade seria um obstáculo à democracia:

"For Rousseau a fair system of justice can only arise out of a democratic polity, one in which the very process of making laws expresses the equality of all citizen." Fleischacker (2004: 61).

Precisamos entender o liberalismo de outra forma porque Dworkin considera que a igualdade é um ideal preterido pela liberdade, numa falsa idéia de que ambos estariam em conflito. Ou seja, para alcançarmos plenamente um, teríamos que abrir mão de outro. Mas para ele, liberdade e igualdade são dois lados da mesma moeda e o liberalismo deve ser baseado na igualdade. A forma como interpretamos o liberalismo e conceituamos essas virtudes determinará ou não o conflito.

Dworkin classifica as teorias contratualistas como descontínuas, ${ }^{96}$ já que há uma separação ou quebra na conexão entre as nossas convicções pessoais, ou ética, e a moralidade, ou nossas convicções políticas. Em outras palavras, nossa ética pessoal seria dada pelo contrato e não pelo que realmente achamos que deveria ser. O ponto central das teorias contratualistas é que os direitos e deveres derivam desse arranjo institucional, o contrato, mas há razões independentes para a aceitação dele. Dworkin quer dizer que, segundo o contratualismo, nossos deveres e direitos, portanto, derivam

\footnotetext{
${ }^{95}$ Adam Smith contribuiu para a idéia moderna de justiça distributiva. Ele recomenda a redistribuição de riqueza de três formas: a primeira por transferências diretas dos ricos para os pobres, a segunda, taxando os mais ricos com uma porcentagem superior a dos pobres e a última, usando as receitas dos impostos, para gerar serviços que beneficiem principalmente os pobres. Ver Fleischacker (2004).

${ }^{96}$ Discussão baseada em Guest (1997).
} 
do contrato e não das nossas convicções privadas. Por isso lhe falta uma força categórica para que o aceitemos. Se antes do contrato não havia direitos e deveres, não podemos usar o contrato como fonte independente daqueles mesmos direitos e deveres. Precisamos de uma justificação moral para aceitá-lo. Um exemplo que pode nos ajudar a compreender a questão é imaginar novamente as partes na "posição original”. Uma vez escolhidos os princípios de justiça, o contrato irá reger a vida pública de cada um de nós. As circunstâncias nas quais eles foram escolhidos, sob o véu de ignorância, não se repetem e teremos que seguir o que foi determinado em contrato, mesmo que nossa situação pudesse ser melhor se não o seguisse ${ }^{97}$.

Outro exemplo da descontinuidade entre ética e moralidade é dado pelo consenso sobreposto (overlapping consensus) ${ }^{98}$. Os princípios liberais estariam conectados com as convicções pessoais, mas ainda assim de uma forma descontínua.

"The overlapping consensus idea is nevertheless a discontinuous one since peoples' rights and duties arise from the different personal moral convictions of each other. That means that Rawls's liberalism must be endorsed for reasons independent of private ethics." Guest (1997:239).

Para Dworkin, os princípios do liberalismo deverão emergir das nossas convicções pessoais. Ele deverá nos mostrar como podemos ter um liberalismo que não apele para a separação da ética da moralidade. Ele acredita que sua versão vai conseguir mostrar que tem força categórica sem a necessidade do contrato. O problema que se apresenta

\footnotetext{
${ }^{97}$ Quanto à discussão sobre interesses antecedentes na posição original, ver “Justiça e Direitos” em LDS. Nesse texto, Dworkin descreve a teoria de Rawls como construtiva e baseada no direito abstrato da igual consideração e respeito.

${ }^{98}$ Rawls modificou o texto da teoria da justiça, já que ela precisava garantir sua superioridade em relação ao utilitarismo e não aparecer apenas como mais uma doutrina. No seu livro Political Liberalism, ele faz suas alterações, por exemplo, dotando a posição original com uma função mais modesta na determinação dos princípios liberais de justiça e apresentando o consenso sobreposto que seria, de forma muito simplificada, o processo que determinaria quais questões ou não estariam na agenda política, "consists of all the reasonable opposing religious, philosophical, and moral doctrines likely to persist over generations and to gain a sizable body of adherents in a more or less just constitutional regime, a regime in which the criterion of justice is that political conception itself" (PL: p. 15). Significa dizer que não é modus vivendi, que seria outra forma de chegarmos a um acordo com relação a uma concepção política, mas uma concepção moral que não se baseia integralmente no autointeresse.
} 
é garantir a neutralidade em relação às nossas concepções de boa vida e ao mesmo tempo não nos separarmos delas para alcançar aqueles princípios do liberalismo na sua versão contínua. Mas não podemos confundir essa neutralidade com relação às concepções do bem como uma suposta neutralidade sobre os princípios de justiça que o liberalismo, considerado como uma teoria de justiça, deve rejeitar ${ }^{99}$. De forma distinta, Dworkin também busca um consenso entre a comunidade e as convicções morais de cada um. Em que esse liberalismo deverá se apoiar?

Estamos aqui diante das questões centrais para este trabalho: o liberalismo visto como uma teoria contínua entre a ética e a moralidade e o liberalismo baseado na igualdade, onde esta não entra em conflito com a liberdade. Podemos apresentar um resumo dos objetivos de Dworkin:

"In brief summary, he says that the metric for distribution must be
economic resources, first because that assumption lies behind any
judgment about the comparative worth of human lives and second,
because treating people as equals means allowing them to live their
lives freely within the resources available to them. For him, equality is
therefore inseparable from liberty. Further, since a person's right to
liberty is "parametered" by this just distribution it means, according
to Dworkin, that people living ethically conflicting different lives
within equality of resources can each approve the political scheme
from each individual ethical perspective". Guest (1995:182).

Ele nos propõe um novo lugar para a igualdade no liberalismo partindo do direito mais abstrato, que as pessoas devem ser tratadas com igual consideração e respeito, do qual derivamos o direito de serem tratadas como iguais. Esse princípio ético abstrato norteará a filosofia política de Dworkin e será, a partir dessa base moral, que se discutirão questões de liberdade, igualdade, democracia e justiça.

Nesse contexto de defesa da igualdade, Dworkin não usa o contrato como forma de dar legitimidade e estabilidade aos princípios de justiça, mas as próprias concepções de boa vida de cada indivíduo que serão realizadas em igualdade de condições, que

${ }^{99}$ ID:328, nota 19. 
significa dizer que partirão de uma igualdade de recursos, meios para alcançar seus objetivos. Mas antes vamos analisar a teoria política e moral sob a qual está a defesa da igualdade, o liberalismo.

Mas o que é liberalismo? No seu texto "Liberalism”100, Dworkin apresenta uma teoria sobre o que é liberalismo, acreditando que ele existe como uma teoria política e não como um conjunto de causas liberais ${ }^{101}$. Para construir seu argumento, ele analisa a política dos Estados Unidos e a diferença entre liberais e conservadores. Será a partir dessa análise que podemos entender porque a igualdade é o valor constitutivo do liberalismo.

Segundo Dworkin, na política americana, os liberais estariam em posições opostas aos chamados “conservadores”, mas a guerra do Vietnã teria descortinado outra realidade, de que a linha que separava os liberais e conservadores era muito tênue. Na verdade não é fácil discernir entre idéias liberais ou conservadoras, como a proteção ambiental ou a defesa dos consumidores. Nos anos 1970, os políticos americanos não se preocupam em ser identificados com uma ou outra posição e acabavam por fazer um mix das idéias dos dois pensamentos ${ }^{102}$.

Foram os governos de Ronald Reagan (1981-1989) e Margaret Thatcher (1979-1990) que acabaram evidenciando as diferenças entre conservadores e liberais. Foram dois governos paradigmáticos no que se referem a reformas tidas como liberalizantes (conservadoras no sentido americano) e, que consistiam, basicamente, na redução da intervenção do Estado na economia, traduzidas em privatizações de serviços, redução de impostos dos mais ricos e desregulamentação dos mercados.

\footnotetext{
${ }^{100}$ Texto que faz parte do livro Uma Questão de Princípio.

${ }^{101}$ Os conceitos de liberalismo, liberal e conservador são usados no contexto norte- americano e não no sentido usualmente empregado no Brasil. Liberais nos Estados Unidos são mais de esquerda e os conservadores, da direita. Aqui liberal é de direita e o conservador seria mais à direita ainda, mas podemos ter a mesma visão de que as diferenças entre os dois também são tênues.

${ }^{102}$ Exemplo utilizado por Dworkin foi o posicionamento de Jimmy Carter, ex-presidente dos Estados Unidos entre 1977 e 1981: era liberal na sua posição sobre os direitos humanos e conservador quando insistia no equilíbrio orçamentário do governo.
} 
Dworkin afirma que o ponto central do liberalismo é uma certa concepção de igualdade que ele chama de “concepção liberal de igualdade”. Mas isso, supondo que o liberalismo seja uma "moralidade política autêntica e coerente"; no entanto, a história parece nos dizer que não é. Para ele, o liberalismo é visto como um conjunto de posições políticas que foram surgindo em várias épocas, e que foram denominadas

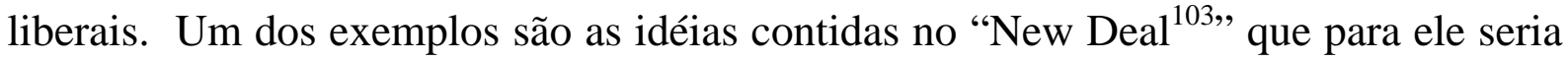
a origem do que chamamos das nossas posições liberais mais recentes. Esse programa, afirma Dworkin

\begin{abstract}
“(...) combinava uma ênfase na redução da desigualdade e no aumento da estabilidade econômica com liberdade política e civil mais ampla para os grupos que faziam campanha por esses objetivos. Nossa noção contemporânea de 'liberal' é formada a partir desse conjunto específico de metas políticas”. (QP: 272).
\end{abstract}

Existem pessoas que não acreditam no liberalismo como uma força política. Para Dworkin, um programa político possui pelo menos dois elementos: as posições políticas constitutivas e as posições derivativas. As primeiras têm valor intrínseco e as últimas, têm seu valor atrelado como meios para atingir as primeiras. Os céticos acreditam, portanto, que o liberalismo não possui elementos constitutivos, apenas derivativos e reunidos por acidente histórico e mantidos por auto-interesse. Para aqueles que acreditam no liberalismo como força política, existem as posições constitutivas, mas é pouco claro quais seriam as derivativas. Isso explicaria, segundo ele, que a “quebra” do "liberalismo do New Deal” foi uma conseqüência das mudanças de opiniões sobre as posições derivativas e não das posições políticas fundamentais.

Será preciso identificar quais as posições derivativas e constitutivas para afirmar se o liberalismo é uma "moralidade política autêntica e coerente”, mas tanto os críticos como os partidários discordam quais seriam elas. Ainda será preciso analisar as conexões teóricas entre, por exemplo, o liberalismo e o capitalismo. Ou ainda,

\footnotetext{
${ }^{103}$ O programa de estímulos econômicos para a recuperação da economia americana após a grande depressão, que se inicia com a quebra da bolsa americana em 1929. O programa foi implementado durante a presidência de Franklin Roosevelt, entre 1933 e 1938.
} 
entender se a liberdade de expressão é um valor constitutivo ou um meio para a democracia.

A pergunta inicial sobre o que é liberalismo, passa a ser: qual a moralidade constitutiva, em particular, do pacote do New Deal?

O argumento para mostrar quando uma posição é constitutiva na teoria política é complexo e controverso e, depende da visão que se tenha do papel da teoria política na política. Para Dworkin, o liberalismo consiste em alguma moralidade política constitutiva que se mantém praticamente a mesma ao longo do tempo e continua influente na política. A moralidade política constitutiva do liberalismo é suficientemente distinta e influente, capaz, portanto, de fazer-nos acreditar na existência do liberalismo, para os liberais e para seus críticos. Isso não significa dizer que são elementos necessários e suficientes para a formação das idéias liberais, mas que possuem essa característica. Em outras palavras:

“Meu projeto adota certa opinião acerca do papel da teoria política na política. Ela pressupõe que o liberalismo consiste numa moral política constitutiva que permaneceu a mesma, em linhas gerais, ao longo de certo tempo e que continua a ser influente na política. Supõe que acordos liberais distintos são formulados quando, por uma razão ou outra, os que são movidos por essa moral constitutiva consideram um esquema particular de posições derivadas como adequado para compor uma teoria política liberal prática, e outros, por seus próprios motivos tornam-se aliados na promoção desse esquema. Tais acordos se desfazem, e também o liberalismo, por conseqüência, quando essas posições derivadas se mostram ineficazes, ou quando as condições econômicas e sociais mudam, tornando-as ineficazes, quando os aliados necessários para formar uma força política efetiva não são mais atraídos pelo esquema. Não quero dizer que a moralidade constitutiva do liberalismo seja a única força atuante no estabelecimento de acordos liberais, ou mesmo que seja a mais poderosa, mas apenas que é suficientemente distinta e influente para dar sentido à idéia, compartilhada pelos liberais e seus críticos, de que o liberalismo existe, e para dar sentido à prática popular de discutir o que ele é." (QP, 278) 
Para encontrar as posições constitutivas, Dworkin nos apresenta uma lista de idéias liberais que seriam as pedras fundamentais para definirmos quão liberais ou conservadores nós somos. A lista foi formulada usando como critério as posições que são incontroversamente liberais:

1. Redução da desigualdade de riqueza via políticas redistributivas baseadas em algum esquema de taxação progressiva;

2. Intervenção do governo na economia para garantir a estabilidade, controlar a inflação, reduzir desemprego;

3. Oferta de serviços pelo governo caso o setor privado não ofereça;

4. A igualdade racial e as políticas para garantia desse direito, impedindo a discriminação no acesso a educação, moradia e emprego;

5. Oposição a formas de regulação da decisão individual controlando a liberdade de expressão, bem como a regulação da literatura sexual e de conduta, mesmo que isso tenha o apoio da maioria;

6. Reservas em relação à legislação criminal e apoio a limites para os procedimentos adotados, sobretudo em casos de confissões.

Dada a lista, Dworkin propõe que uma concepção particular de igualdade pode ser constitutiva daquelas posições liberais e ajudaria a determinar se uma posição é realmente liberal. Mas existem alguns ideais constitutivos independentes que poderiam estar nas listas de conservadores e de liberais. Os mais importantes seriam: a liberdade e a igualdade, ou seja, valores das democracias modernas. Liberdade e igualdade muitas vezes estão em conflito e o governo deverá estabelecer políticas que podem favorecer um ou outro valor democrático. Mais adiante veremos que, para ele, esses 
conceitos não estão em conflito, ao contrário, são inseparáveis e fazem parte de um único ideal político.

A diferença entre liberais e conservadores estaria no peso dado para a liberdade e a igualdade. Os liberais são identificados como aqueles que dão mais importância à igualdade em detrimento à liberdade e os conservadores, o contrário. Mas quanto de um e de outro, é uma questão em aberto ${ }^{104}$.

"Liberalism has often been said to be incoherent as well as outmoded, just a rag bag of positions developed by different politicians who chose to call themselves liberals." Dworkin (1983a:1).

Se o ponto central da teoria é uma competição entre liberdade e igualdade como podemos chegar ao liberalismo? Não podemos quantificar a liberdade. Não conseguimos medir um conservador ou um liberal pela "diferença” entre os pesos de cada um para liberdade e igualdade. A solução viria pela métrica da igualdade? Em parte sim, mas apenas se conseguirmos identificar que, para o liberal, o que a igualdade requer é distinto do que o é para um conservador.

Para dar continuidade ao segundo, Dworkin utiliza o conceito de direitos, bastante importante para suas discussões sobre a interpretação da constituição americana. Existem dois direitos básicos ${ }^{105}$ que podem ser tomados como princípios que tornam a

\footnotetext{
${ }^{104}$ Para Dworkin, o liberalismo pensado numa relação entre liberdade e igualdade deixa espaço para aqueles que preferem muito mais igualdade que liberdade, se afastando do que seria um liberal. $\mathrm{O}$ liberal, portanto, é um homem "in the middle", ou seja, no meio termo entre as duas posições e por isso, o liberalismo muitas vezes é considerado uma teoria "wishy-washy", uma teoria indecisa, fraca. 105 Ele explica que o conceito mais abstrato de igualdade é defendido pela $14^{\mathrm{a}}$. Emenda da Constituição americana, na qual nenhum estado da federação poderá negar a qualquer pessoa o direito à igual proteção da lei. A emenda acima foi usada como argumento para o caso DeFunis versus Odegaard de 1974. Em 1971, um jovem judeu se candidatou para a Escola de Direito da Universidade de Washington, mas foi recusado. Se ele fosse mexicano, filipino ou negro, teria nota suficiente. Sua alegação era que a universidade violava seu direito expresso na $14^{\mathrm{a}}$ emenda, porque as notas requeridas pelas outras minorias eram menores. Em 1945, Sweatt (Sweatt versus Painter), um jovem negro, candidatou-se para a Escola de Direito da Universidade do Texas e foi recusado porque era negro. A mesma emenda foi usada em sua defesa. Ver cap. 9 em LDS.
} 
igualdade um ideal político: o primeiro é o direito a um tratamento como iguais, que significa que temos o direito a igual consideração e respeito, não significando que recebemos a mesma distribuição de algum bem ou recurso, e o segundo é ser tratado igualmente na distribuição de algum recurso ou oportunidade. É a idéia mais abstrata de tratar as pessoas como iguais, em que ele busca evidenciar a força da igualdade na sua filosofia política e na sua filosofia do direito.

Segundo Dworkin, se considerarmos apenas as controvérsias político-econômicas podemos dizer que os liberais querem mais igualdade na forma do primeiro direito, de ser tratado igualmente, se comparados com os conservadores. Para o autor, tratar como igual é o mais fundamental porque supõe que liberais e conservadores consideram que o primeiro direito é constitutivo e o segundo, derivativo ${ }^{106}$. Tratar todos igualmente não garante que as pessoas sejam tratadas como iguais. Um exemplo são as cotas nas universidades, que não tratam as pessoas como iguais, dadas as desigualdades passadas das minorias beneficiadas por essa política.

Para Dworkin, devemos desconsiderar que o liberalismo é uma disputa entre liberdade e igualdade e assumir que o primeiro princípio, de tratar a todos com igual consideração e respeito, é amplamente aceito pelas democracias modernas. O que significa tratar a todos com igual consideração e respeito ou como iguais? Podemos responder de duas formas. A primeira supõe que o governo seja neutro em relação ao que consideramos ser uma boa vida ou ao que damos valor na vida. A segunda forma diz que o governo não pode ser neutro em qualquer aspecto, já que não se pode tratar as pessoas como iguais sem uma teoria de como as pessoas devem ser.

O liberal é aquele que defende a neutralidade do Estado em relação às concepções de boa vida. Isso é o que a teoria liberal da igualdade requer. O liberal deverá encontrar formas de satisfazer o tratamento igual, dada a pluralidade de valores que cada um tem, bem como suas preferências. Aqui já é uma pista sobre o que o autor nos 
apresentará como sua alternativa tanto ao bem-estar dos utilitaristas quanto aos bens primários de Rawls. Para Dworkin se um liberal fosse chamado para construir um novo Estado, ele deveria propor uma teoria geral de distribuição de bens ou oportunidades. Ele chegaria à idéia de que esses bens e oportunidades devem ser distribuídos igualmente para a satisfação das preferências de cada um. O autor chama essa idéia inicial de "princípio de igualdade bruta”. A primeira crítica poderia vir daqueles com gostos dispendiosos que pediriam por mais recursos ${ }^{107}$. Mas a resposta dele seria que gostos não são como doenças ou deficiências, eles são cultivados de acordo com o que cada um concebe como uma boa vida. E a neutralidade é alcançada da seguinte forma:

\begin{abstract}
"A neutralidade mais eficiente, portanto, exige que a mesma parcela seja destinada a cada um, de modo que a escolha entre gostos dispendiosos e gostos menos dispendiosos seja feita por cada pessoa, sem nenhuma noção de que a parcela que lhe cabe será aumentada se escolher uma vida mais dispendiosa ou que, seja o que for que escolher, sua escolha subsidiará os que escolheram viver mais dispendiosamente." (QP: 288).
\end{abstract}

A neutralidade está em instituir uma distribuição de recursos que deverá ser igualitária e cada um terá a liberdade de fazer o que quiser com eles ${ }^{108}$. Se todas as pessoas tivessem o mesmo talento, ambição, o mesmo acesso à educação e demais serviços públicos de qualidade, se cada um começasse a vida com os mesmos recursos, essa forma bruta de igualdade de tratamento seria suficiente. Mas a realidade não é essa e o liberal precisará de mecanismos que satisfaçam o princípio de igual tratamento levando em conta as diferenças entre as pessoas.

\footnotetext{
107 No capítulo sobre a distribuição de recursos vamos apresentar de forma mais completa como Dworkin resolve a questão dos gostos dispendiosos e de como eles são o ponto fraco do utilitarismo como teoria da justiça. Sobre a questão discutida no texto, as deficiências, apesar de serem um argumento mais forte que os gostos dispendiosos, não invalidam o "princípio de igualdade bruta", mas sinalizam para a necessidade de correções na sua aplicação. É o que ele apresenta adiante como um mercado hipotético de seguros. Ver em Dworkin (1985:409, nota 5).

${ }^{108}$ Esses são pressupostos fundamentais da tese de Dworkin: a igual consideração e respeito e a responsabilidade individual. Quando tratarmos do modelo hipotético de distribuição de recursos, vamos entender melhor as implicações desses pressupostos em relação a outras teorias como a igualdade de bem-estar, de bens primários e de capacidades.
} 
As instituições escolhidas pelo liberal para fazer essa repartição de recursos entre pessoas com diferentes concepções de boa vida serão o mercado e a democracia representativa $^{109}$. O mercado tem uma função de alocação de recursos, nossas decisões de produção, consumo e investimento. A defesa aberta de Dworkin do mercado pode causar espanto para aqueles que acreditam que ele é fonte geradora de desigualdade. Mas deve ser vista como uma tentativa de conciliar o mercado com a justiça ${ }^{110}$, já que para ele a desigualdade distributiva é fruto de uma ordem jurídica, ou seja, das leis que governam a propriedade, contratos, crimes, a previdência, as políticas fiscais, a proteção ambiental, os direitos políticos entre outras ${ }^{111}$. Numa situação em que as diferenças estão apenas nas preferências, o mercado é mais igualitário do que outra alternativa.

Mesmo diante das deficiências do mercado real, Dworkin acredita que podemos nos valer de sua função como mecanismo alocativo. Se o mercado funcionasse de forma eficiente, poderíamos alcançar uma distribuição igualitária, ou seja, o custo de satisfazer as preferências das pessoas deveria ser o mais próximo possível do custo de satisfazer as preferências dos outros. Esse custo seria dado pelo mercado ${ }^{112}$.

"O mercado, se for possível fazê-lo funcionar com eficiência, determinará para cada produto um preço que reflita os custos em recursos de material, trabalho e capital que poderiam ser aplicados para produzir algo diferente que alguma outra pessoa queira. Esse custo determina, para qualquer um que consome o produto, quanto se deve debitar de sua conta no cálculo da divisão igualitária dos

\footnotetext{
109 A necessidade dessas instituições, sobretudo de uma democracia representativa pode ser questionada por governos cujas formas de poder não se encaixariam neste modelo. Observa-se pelos dados que os países que adotam a democracia representativa são os mais ricos, mas alguns ainda são desiguais, como Brasil, Estados Unidos, por exemplo. As instituições acima podem ser consideradas como necessárias, mas não suficientes para garantir a igualdade entre os indivíduos.

${ }^{110}$ Macleod (1998) afirma que o mercado estaria longe de atender às demandas da justiça igualitária e que a conciliação do mesmo com a justiça não foi alcançada por Dworkin. Para o autor, o uso de instrumentos como o mercado poderá distorcer nosso entendimento da justiça. Mas, ao contrário do que afirma, Dworkin não assume um mercado ideal, senão seria o mecanismo suficiente para chegarmos a uma distribuição igualitária e poderíamos prescindir da democracia representativa. Para Dworkin, a ordem jurídica é a fonte das desigualdades e não apenas o mercado.

${ }^{111}$ Dworkin (2000: IX -X).

112 Já tivemos exemplo na história em que economias planificadas eram ineficientes e produziam menos recursos. Além disso, a igualdade prometida também nunca foi comprovada.
} 
recursos sociais. Oferece uma medida de quanto mais se deve debitar de sua conta em vez de um livro, e por um livro em vez de outro. $O$ mercado também fornecerá, para o trabalhador, uma medida de quanto se deve creditar em sua conta por ter escolhido a atividade produtiva ao lazer, e por uma atividade em vez de outra. (...) Essas medições tornam a própria distribuição de um cidadão uma função das preferências pessoais de outros, bem como das suas, e é a soma das preferências pessoais que fixa o verdadeiro custo para a comunidade de satisfazer as preferências por bens e atividades. A distribuição igualitária, que exige que o custo de satisfazer as preferências de uma pessoa deve ser igual, tanto quanto possível, ao custo de satisfazer as de outra, não pode ser imposta a menos que sejam feitas essas medições.” (QP: 289-90)

Somente o mercado, na visão de Dworkin, poderá nos fornecer as medidas a serem igualadas, quais sejam, os custos de satisfação de uma pessoa serem iguais a dos demais. O mercado nos dará o custo (ou valor) de bens, do trabalho e do capital e sem isso, não seria possível contabilizar as preferências pessoais que, por sua vez, é o custo para a comunidade das escolhas pessoais de trabalho (e lazer) e bens ${ }^{113}$.

Algumas desigualdades serão produzidas pelo mercado, parte delas serão moralmente aceitas pela concepção liberal de igualdade, mas outras diferenças não.

"O legislador liberal enfrenta uma tarefa difícil. Sua concepção de igualdade exige um sistema econômico que produza certas desigualdades (as que refletem os custos diferenciais verdadeiros de bens e oportunidades), mas não outras (as que decorrem de diferenças de capacidade, herança, etc). O mercado produz as desigualdades exigidas e as proibidas, e não há nenhum sistema alternativo no qual se possa apoiar para produzir as primeiras sem as segundas.” (QP: 292)

As diferenças que serão intoleráveis para um liberal serão aquelas relacionadas com deficiências físicas, mentais e emocionais que trazem uma desvantagem para essas pessoas no mercado. Podemos ver que o autor novamente nos apresenta sua teoria de

\footnotetext{
${ }^{113}$ O conceito de custo para Dworkin é fundamental para que entendamos qual o papel do mercado como forma de alcançar a melhor alocação possível de recursos. Veremos que no capítulo seguinte esse custo será chamado de custo de oportunidade.
} 
justiça distributiva ressaltando que há desigualdades imerecidas e que o liberal não poderá aceitar.

Além do mercado, o liberal tem os mecanismos oferecidos pela democracia representativa. A democracia permitirá que cada pessoa tenha o direito de ser tratada com igual consideração e respeito. Mas as decisões políticas, assim como o mercado, estão longe da perfeição. Elas são influenciadas não apenas pelas nossas preferências pessoais, mas pelas preferências externas ${ }^{114}$ também. Esse último tipo de preferência é aquele que nós temos sobre o que outros devem fazer ou ter. Dado que as preferências externas poderão invadir a nossa liberdade e desrespeitar o princípio da igualdade, Dworkin nos aponta o lugar da democracia na sua concepção de liberalismo. Ela será fundamental para garantir os nossos direitos e deveres fundamentais. ${ }^{115}$

Mais uma vez o liberal deverá tratar de uma questão complicada: como separar as preferências pessoais e externas? Muitas vezes é impossível, como no exemplo do autor a seguir. Dworkin lembra o caso das preferências associativas, que são aquelas que as pessoas têm por oportunidades iguais como o acesso à educação pública, mas apenas para aquelas com o mesmo “background”. Tal oportunidade, porém, viola claramente o direito das pessoas serem tratadas como iguais.

Dworkin aponta a solução de forma complexa. O liberal deverá ter em mãos direitos civis que nos levem a decisões políticas que incorporem as preferências externas, mas que as removam das instituições políticas majoritárias. Ou seja, as preferências externas não deverão estar na formulação daquelas instituições. Nos Estados Unidos, a “Bill of Rights” da Constituição seria um exemplo desses direitos.

\footnotetext{
${ }^{114}$ Sobre os tipos de preferências, ver LDS, capítulo 9.

${ }^{115}$ Vita (2007) considera que a distinção de Dworkin sobre as preferências é problemática porque alguns podem argumentar que a preferência pela justiça possa ser tida como externa, mas considera que é pertinente quando falamos de preferências desprezo ou preconceito em relação a um grupo de pessoas ou seu modo de vida. Ver discussão de Vita (2007: 288-90).

Nesse trecho faz menção da discussão de Dworkin com Lord Devlin sobre um relatório que sugeria a descriminalização dos atos homossexuais. Esse texto de Dworkin está em LDS.
} 
"O esquema de direitos necessário para isso dependerá das características gerais dos preconceitos e de outras preferências externas da maioria em qualquer época dada, e liberais diferentes discordarão quanto ao que é necessário em qualquer época determinada.” (QP: 294).

Considerando que o mercado e as instituições democráticas podem gerar desigualdades inaceitáveis moralmente, os cidadãos precisam ser protegidos por um conjunto de direitos individuais. Dessa forma, eles poderão resistir a determinadas decisões mesmo que elas tenham sido fruto do mercado e da democracia. Esses direitos garantem o que a igualdade requer, isto é, que as pessoas sejam tratadas com igual consideração e respeito. Por isso, Dworkin fala que esses direitos individuais são como um trunfo (trumps cards) que cada cidadão pode dispor. Daí a importância que Dworkin dá à estrutura jurídica quando discutimos a justiça distributiva.

Uma ressalva que ele faz é que, apesar da relevância dos direitos individuais para a garantia do princípio mais abstrato de igualdade, eles não devem ser entendidos como representando a igualdade em competição com outros objetivos independentes como a eficiência. Os direitos têm a ver com a moralidade política de forma independente, ou seja, o autor não coloca esses direitos, que buscam a salvaguarda da igual consideração, em oposição a algum critério de eficiência.

“Para o liberal, os direitos são justificados não por algum princípio
que se opõe a uma justificativa independente das instituições políticas
e econômicas que eles modificam, mas para aperfeiçoar a única
justificativa de que se podem valer essas outras instituições. Se os
argumentos liberais a favor de um determinado direito são bem
fundamentados, então o direito é um fator de aperfeiçoamento da
moralidade política sem alterá-la, não uma transigência necessária,
mas lamentável, com algum outro objetivo independente, como a
eficiência econômica." (QP: 296). E se o conservador fosse chamado para fazer o mesmo exercício de nos apresentar uma constituição? Sem titubear ele também teria o mercado e a democracia como instituições políticas, mas o papel delas seria distinto. O mercado também alocaria os recursos, premiando os mais talentosos e capazes, e a democracia garantiria as oportunidades para os membros da comunidade. A maior diferença entre os dois seria 
o papel dos direitos individuais para a correção das decisões provenientes daquelas instituições. O mercado, para o liberal, irá gerar as desigualdades imerecidas que devem ser compensadas de alguma forma, para o conservador, ele premiará os mais talentosos. Na democracia, o conservador não encontrará os mesmos problemas que o liberal tentará resolver e, por isso, não tentará excluir as preferências externas que possam ferir o princípio da igualdade, sobretudo as preferências moralistas. Para o conservador, a democracia deverá defender os mais virtuosos, com um sistema de direitos de propriedade para proteger tudo que for adquirido com talento e esforço pessoais. Os conservadores, em geral, serão contra quaisquer políticas de ação afirmativa, já que eles condenam a igualdade de oportunidade que busque a igualdade de resultado. Se recordarmos a lista de idéias liberais que apresentamos no texto, podemos ver que os conservadores acham que o sexo é mais perigoso que as armas, ao pedirem o controle da pornografia e a liberação do comércio de armas para os civis (exemplo do próprio autor).

Para Dworkin, o liberalismo é forte e consistente quando podemos identificar uma agenda, ou quais seriam suas posições políticas derivadas do que ele chama de moralidade constitutiva. É preciso estudo e análise para a definição dessa agenda; apenas evidenciar que a moralidade constitutiva é a igualdade, e que requer neutralidade entre as concepções de boa vida, não resolve todo o problema. Dworkin afirma que o liberalismo não pode se basear no ceticismo porque define o que é errado e certo ao enunciar seu princípio constitutivo, a igual consideração e respeito por todos. Também não é contraditório, porque precisamos entender que o princípio da igualdade é requerido pela justiça e não uma forma de viver.

Sobre a idéia de que o liberalismo pode ser um sistema injusto que se auto-alimenta, o autor diz que isso faria sentido se ele se baseasse em alguma versão do utilitarismo. $\mathrm{O}$ liberalismo busca um sistema de distribuição justo e não que seja testado pelas preferências que este sistema produz. É por isso que o liberal se preocupa com as instituições e direitos individuais como forma de obedecer ao princípio da igualdade. As preferências não são parâmetros para julgarmos o liberalismo em questão. 
Em resumo, o liberalismo tem, como posição constitutiva, a igualdade, e o meio de alcançarmos o que ela requer será o mercado e a democracia, mesmo imperfeitos, mas essenciais para a correção das desigualdades moralmente inaceitáveis. Ainda, o liberalismo requer a neutralidade por parte do Estado em relação às concepções de boa vida.

Do ponto de vista de Dworkin, o liberalismo não é baseado no ceticismo, ou seja, posição filosófica de que não é possível identificar o que é bom para a vida. A moralidade constitutiva nos diz que devemos tratar a todos como iguais, não porque não existe certo ou errado, mas porque isso é o correto. Essa será a base para a nossa discussão sobre como o liberalismo de Dworkin permite que tenhamos uma relação contínua entre a ética e a moralidade fugindo da esquizofrenia do contratualismo que quer separar essas esferas. O indivíduo está livre para buscar seu interesse próprio, desde que respeite as regras de um Estado que vai tratar a todos como iguais.

\subsection{Tipos de Liberalismo}

Vamos discutir uma classificação de tipos de liberalismo apresentada por Dworkin em dois textos publicados nos anos $1980^{116}$. Mesmo não utilizando essa mesma nomenclatura, podemos entender as diferenças mais importantes da sua versão para o liberalismo e a versão, digamos, utilizada por Rawls e outros liberais.

\footnotetext{
116 Dworkin publica no mesmo ano de 1983 dois artigos na New York Review of Books ("What Liberalism Isn't" e "Why Liberals Should Believe in Equality"). No primeiro texto ele aponta as fraquezas da versão do liberalismo baseada na neutralidade e no segundo texto, faz uma defesa do liberalismo baseado na igualdade. Depois Dworkin não utilizará mais essa forma de classificar o liberalismo, já que no seu livro A Virtude Soberana complementará sua tese de que a igualdade e a liberdade fazem parte de um único ideal político. No entanto, será muito útil entender como ele conecta os conceitos de igualdade e neutralidade para assumir um liberalismo do tipo contínuo.
} 
O ponto central do autor nesses textos é demonstrar que se o liberalismo não se “ancorar” na igualdade, ele estará vulnerável a políticas que promovem a desigualdade econômica ao invés de combatê-la.

Para demonstrar o seu argumento, Dworkin afirma que o liberalismo tem dois aspectos que estão sob ataque, a neutralidade do Estado em relação à moralidade pessoal e a responsabilidade do Estado perante a desigualdade econômica. Como esses dois aspectos estariam relacionados?

Existem duas versões de liberalismo em oposição uma com a outra. A primeira é o liberalismo baseado na neutralidade, ou seja, que o Estado não interfere nas escolhas morais de seus cidadãos, e a igualdade seria uma conseqüência dessa posição neutra. Os liberais acreditam na igualdade porque a neutralidade a requer, portanto a igualdade deixa de ser o objetivo primário do liberalismo, sob essa ótica. Alguma forma de igualdade emergirá do compromisso com a neutralidade.

A segunda versão é o liberalismo baseado na igualdade, para o qual a neutralidade é conseqüência do compromisso com a igualdade, que não é uma virtude derivada, mas a essência do liberalismo. Para Dworkin, se aceitamos esse tipo de liberalismo, podemos rejeitar qualquer tentativa de imposição de uma concepção de bem, já que se isso ocorrer, não estaríamos sendo tratados com igual consideração e respeito.

O liberalismo baseado na neutralidade, por sua vez, não é forte o bastante para questionar políticas como as da "Nova Direita" americana que deseja suprimir os programas de redistribuição de renda. O argumento desta é utilitarista, ou seja, propõe sacrifício aos beneficiários desses programas, a fim de que a economia tenha desempenho melhor no futuro. Supostamente em prol da comunidade como um todo, esses programas deveriam acabar.

Mas o que é ser liberal nesse sentido? 
"Liberals argue, against the moral majority and another moral fundamentalists, that politics must be neutral in one particular way: among conceptions of the good life. Whatever we may think privately, it cannot count, as a justification for some rule of law or some political institution, that a life that includes reading pornography or homosexual relationships is either better or worse than the life of someone with more orthodox tastes in reading or sex. Or that a life suffused with religion is better or worse than a wholly secular life." Dworkin (1983a: 4).

A citação anterior apresenta o que é fundamental para um liberal, a neutralidade em relação às concepções de boa vida, mas isso não significa dizer que eles são neutros em relação ao que seria uma boa sociedade, ou seja, que preferem que as pessoas vivam bem a serem miseráveis, que não sejam conformistas, mas criativas e pujantes. Ainda, também não significa que a política deva ser neutra entre princípios de justiça, já que o próprio liberalismo é uma teoria de justiça com suas controvérsias. Assim, segundo Dworkin, o liberalismo apenas deveria rejeitar as teorias de justiça que assumem um modelo de boa vida como melhor que outro.

Se assumirmos que a neutralidade é independente da igualdade, não há argumentos para defender uma intervenção do Estado quando as pessoas sofrem uma perda nos seus negócios dada uma tragédia natural, ou ainda, pessoas com necessidade especiais. Para esses liberais, também não há como justificar políticas de redistribuição de renda ou de compensação. Esse é um argumento usado pela direita norte-americana (exemplo o governo Reagan). Podemos dizer então que a neutralidade, deste ponto de vista, nos leva à desigualdade. Dworkin quer mostrar que a neutralidade, assim concebida, não tem força diante do argumento contra a igualdade econômica.

O liberalismo baseado na igualdade insiste que o governo deve tratar a todos com igual consideração, ou seja:

"It must impose no sacrifice or constraint on any citizen in virtue of an argument that the citizen could not accept without abandoning his sense of his equal worth." Dworkin (1983b:1). 
O liberalismo baseado na igualdade tem como princípio que as pessoas devem ser tratadas como iguais e a neutralidade moral é requerida apenas quando a igualdade a requerer. Em termos econômicos, tratar as pessoas como iguais é provê-las de uma parcela justa de recursos:

"For treating people as equals requires that each be permitted to use,
for the projects to which he devotes his life, no more than an equal
share of the resources available for all, and we cannot compute how
much any person has consumed, on balance, without taking into
account the resources he has contributed as well as those he has taken
from the economy." Dworkin (1983b:2).

Nossas escolhas entre lazer e trabalho, uma clássica forma de explicar os trade-offs da economia, vão determinar quanto cada um poderá ter dos recursos ${ }^{117}$. Portanto, para aqueles que decidiram investir mais em atividades produtivas e tiveram um resultado positivo, multiplicando seus recursos, não há razão para retirar qualquer parcela de recurso para ser dado a outrem. Para Dworkin, não existe a punição dos talentosos, e de outro lado, também não há a benemerência com os preguiçosos.

Isso não significa dizer que as pessoas sempre terão a mesma parcela de recursos o resto da vida. Ao longo da nossa existência, o governo comprometido com essa teoria da justiça irá tomar medidas para reduzir as desigualdades geradas pelo mercado. Nem todas as circunstâncias serão passíveis de intervenção, justamente para que se garanta a igual consideração. Somente em circunstâncias não escolhidas pelas pessoas serão compensadas, como deficiências físicas, por exemplo ${ }^{118}$.

\footnotetext{
${ }^{117}$ Vamos ver que a igualdade de recursos de Dworkin, que propõe uma distribuição igualitária inicial, não deve ser confundida com a teoria de Harsanyi ou com as teorias da linha de largada. A principal distinção está justamente que Dworkin identifica que há desigualdades imerecidas a ser compensadas por algum sistema de redistribuição de recursos. Isso Harsanyi nem de longe vislumbra, já que os talentosos devem ser premiados.

${ }^{118}$ Vamos discutir esse tempo fundamental quando falarmos da igualdade de recursos. Importante é a distinção feita por Fleurbaey (2008) sobre responsabilidade: um grupo de autores aponta que as pessoas devem ser responsáveis apenas pelo que está em seu controle (Arneson, Cohen e Roemer) e outro grupo afirma que as pessoas devem ser responsáveis pelas suas preferências e as escolhas que provém delas, no qual temos Dworkin e Rawls.
} 
Dworkin acredita que por isso os liberais assumem o mercado como um mecanismo de alocação de recursos. Com um mercado eficiente, se cada um começasse com uma igual parcela de recursos, além de um acesso igualitário à educação e informação, ninguém iria questionar as parcelas obtidas no mercado após suas decisões de consumo, investimento, trabalho e lazer. Mas o mercado não é eficiente e sabemos que não começamos com parcelas iguais de recursos. Essa disparidade pode ainda aumentar se consideramos outro elemento: a sorte, ou o azar, como queiram. As pessoas são diferentes em várias dimensões e o mercado irá evidenciá-las. Portanto, um liberal não deverá aceitar que os resultados do mercado são igualitários e algum tipo de redistribuição deverá ser feito. Dworkin sabe que nenhum programa de redistribuição de renda é perfeito, mas mesmo assim ele insiste que um governo não poderá deixar de lado esse tipo de política.

\footnotetext{
"We must be content to choose whatever programs we believe bring us closer to the complex and unattainable ideal of equality, all things considered, than the available alternatives, and be ready constantly to reexamine that conclusion when new evidence or new programs are proposed."119 Dworkin (1983b:3).
}

O autor também busca responder à questão: a igualdade de recursos deve ser buscada independente do custo para uma economia como um todo? Mesma questão apresentada de outra forma por Dworkin em Calabresi (1979):

"The question is not whether redistribution inhibits efficiency or whether a great decline in efficiency hurts the poor. It is whether justice is better served by some redistribution at the cost to some efficiency.” Calabresi (1979:558).

Ele apresenta a questão porque vários economistas, sobretudo neoclássicos, julgam que reduzir a desigualdade por meio da redistribuição de recursos tem efeitos negativos sobre o crescimento de longo prazo. Para Dworkin, o argumento é

\footnotetext{
${ }^{119}$ Aqui ele já está falando do seu modelo de seguro hipotético, sobre o qual acabava de escrever.
} 
duvidoso $^{120}$ e utilitarista, porque nega o benefício de uma política redistributiva para alguns em prol da sociedade como um todo. Aqui não está em questão a eficiência, mas a igualdade que requer que todos sejam tratados com igual consideração e respeito. Ele assume que essas políticas não irão resolver todos os problemas, mas vão mitigar parte das desgraças sociais que presenciamos.

“... people must not be condemned, unless this is unavoidable, to lives in which they are effectively denied any active part in the political, economic, and cultural life of the community. So if economic policy contemplates an increase in unemployment it must also contemplate generous public provision for retraining or public employment. The children of the poor must not be stinted of education or otherwise locked into positions at the bottom of society. Otherwise their parents' loyalty to them acts not as a bridge but as a bar to any identification with the future these parents are meant to cherish.” Dworkin (1983b: $6)$.

Dworkin apenas delineia o que um governo preocupado com a igual consideração poderá fazer. Um governo real deverá priorizar as políticas públicas, mas nunca deixar de lado as políticas redistributivas. O que faltou à agenda liberal para o período da crise de 30 até os anos 60 foram justamente os direitos econômicos em períodos difíceis, ou seja, quando o crescimento está deprimido, que tipo de política deve ser garantido em nome da justiça? Aqui Dworkin destaca a importância dessas políticas para a sociedade ao usar as palavras de Lyndon Johnson, "social justice would make the society great”. Ele nos dá a resposta para a pergunta inicialmente feita. O governo deve buscar a igualdade, priorizando recursos, visto que sempre eles são finitos, mas nunca abrindo mão das políticas redistributivas. O argumento utilitarista deverá ser rejeitado por completo. Dworkin diz que o importante são os cidadãos do presente, os vivos, que não devem aceitar a justificativa para uma política baseada num retorno no futuro. Se esta é a proposta de um governo para o presente, devemos rejeitar, também, esse futuro.

${ }^{120}$ Não há comprovação empírica na literatura pertinente de que políticas redistributivas afetam negativamente o desempenho de longo prazo da economia. 
A seguir vamos apresentar a versão de Dworkin para o liberalismo baseado na igualdade, a igualdade liberal.

\subsection{A Igualdade Liberal e a Métrica do Valor da Vida}

A proposta de Dworkin é dotar o liberalismo de uma justificativa moral, para isso é preciso recuperar as suas bases éticas em oposição ao liberalismo que distingue a perspectiva pessoal, ou seja, nossas concepções de boa vida, da perspectiva política, onde cada um de nós trata das questões políticas e sociais.

Em outras palavras, o liberalismo separa a ética, que contem convicções sobre quais tipos de vida são boas ou ruins para um indivíduo, da moralidade, que contém os princípios sobre como a pessoa deve tratar as demais e como deve alcançar a boa vida. Essa separação para Dworkin é esquizofrênica. Seriam as nossas convicções pessoais que nos dariam os princípios do liberalismo ${ }^{121}$. Sem essa base moral, o liberalismo passa a ter que justificar questões como a separação entre comunidade e indivíduo ou entre o justo e o bem, alvos das mais fortes críticas. Ele apresenta essa idéia de forma mais sistemática na sua Tanner Lecture "Foundations of Liberal Equality"122 e, com algumas pequenas mudanças, publica no seu livro A Virtude Soberana. A sua versão ele chama de “igualdade liberal” e representa uma alternativa à “justiça como equidade” de Rawls como uma concepção política de justiça.

"Now liberal equality requires individuals to assess whether they are disadvantaged compared to others in the light of their own distinctive comprehensive convictions. (...) In an environment in which there exist divergent conceptions of the good life, Dworkin supposes that his critic would advocate 'a special, made-for-politics morality', a morality which all can accept and refer to in adjucating their

\footnotetext{
${ }^{121}$ Guest (1995:239).

122 Sobre a Tanner Lecture ver em Darwall org. (1993) Equal Freedom que também reúne artigos de Quentin Skinner, Thomas Scanlon, John Rawls, Amartya Sen e G.A. Cohen.
} 
competing claims when acting as political agents, even if various individuals or groups reject that morality as an appropriate guide to their own ethical lives." Clayton (2002:11).

A sua versão do liberalismo quer que as nossas convicções garantam a "força categórica”123 para sua aceitação e apoio, por isso esse tipo de versão seria chamada de teoria contínua. As teorias contratualistas têm como força categórica o contrato e são chamadas de descontínuas, já que não pretendem partir das nossas convicções. Essas teorias não teriam força categórica porque, se não existem direitos e deveres antes do contrato, como pode existir um contrato independente como fonte de direitos e deveres que o liberalismo requer? É muito mais fácil endossar uma estrutura política que surge das nossas próprias convicções sem a necessidade de um contrato. O que precisamos é de uma força moral independente que tenha apelo junto a diferentes convicções pessoais. Uma forma de fazer isso é a abordagem interpretativa para unir a perspectiva pessoal e a política. Se estivermos buscando algum consenso sobre os princípios de justiça, e se tivermos duas interpretações, ambas plausíveis, como poderemos decidir? Precisamos de um julgamento independente para saber qual a interpretação correta e saber o que aquele consenso significa.

"That independent judgment must be provided for within a theory of
justice which is more abstract than the theory that says that the
principles lie within the consensus. That further theory of justice,
Dworkin says, must be the one that supplies the categorical force:
At some point we must rely on what (we believe) is true about matters
of justice in order to decide which interpretation of our own traditions
- which way of telling our story - is best." Guest (1997: 243).

O liberalismo concebido como igualdade liberal define a igualdade em termos de recursos, a liberdade é aquela na qual tomamos atitudes e ações, respeitando os direitos do próximo e não fazendo o que bem entendemos e, finalmente, a comunidade deve se basear no respeito compartilhado e concreto por aquela liberdade e pelas responsabilidades individuais. Isso é o que ele chama de "tecido emocional” do

${ }^{123}$ Ver capítulo 11 de Guest (1997). 
liberalismo $^{124}$, ou seja, concebermos os três ideais - liberdade, igualdade e comunidade, daquela forma.

Na igualdade de recursos não determinamos uma lista de bens, ou bens primários, que devem ser distribuídos igualmente, ao contrário, cada pessoa escolhe a cesta de bens que deseja, dada uma parcela justa de recursos que lhe cabe. A igualdade é determinada ex ante a uma cesta de bens que é determinada de acordo com as convicções ou concepções de boa vida de cada um.

Dworkin identifica três acusações ao liberalismo. A primeira diz que uma vida genuinamente boa não é possível sob o liberalismo; a segunda acusa o liberalismo de subordinar a busca pela vida boa à justiça social, que é posta em primeiro lugar, e a terceira é que o liberalismo é eticamente neutro, ou seja, dá demasiada importância aos princípios de justiça e pouca atenção à qualidade e o valor da vida que as pessoas levam. A neutralidade em relação às concepções de boa vida é a base do pensamento liberal e Dworkin não tenta evitá-la, como vimos nas seções anteriores. A neutralidade para ele existe no nível que a igualdade de recursos requerer, ou seja, enquanto obedecer ao princípio da igual consideração e respeito. O que ele diz é que o Estado pode e deve ser neutro em alguns níveis relativamente concretos da ética, mas não nos níveis mais abstratos com relação ao caráter, à força e à postura de como viver ${ }^{125}$. Mas as respostas que daremos às questões abstratas têm seu efeito sobre as mais concretas.

Dworkin afirma que o liberalismo consiste numa moralidade política e acha que é possível mostrar que há uma concepção de igualdade que é constitutiva das chamadas “posições liberais”, como vimos na seção anterior. O liberalismo partilharia dos mesmos princípios constitutivos que outras teorias políticas, mas a diferença estaria na importância relativa de diferentes princípios, como a liberdade e a igualdade. A pergunta não seria se os conservadores dão menos valor à igualdade que um liberal, 
mas qual a sua concepção do que a igualdade requer. Para os liberais, a concepção do que a igualdade requer é que todos sejam tratados com igual consideração e respeito, base de toda a discussão de Dworkin sobre os fundamentos éticos do liberalismo.

A igualdade liberal expressa dois princípios amplamente aceitos: toda a vida deve ser bem sucedida e não desperdiçada e cada um de nós tem responsabilidade especial sobre esse êxito ${ }^{126}$.

Neste mesmo texto, ele apresenta qual seria a concepção correta do valor de uma vida boa, ou seja, como definir o que é uma vida boa, sua métrica, que ele chama de "modelo do desafio" e expõe os pressupostos da justiça distributiva derivada da sua versão de liberalismo, a "igualdade de recursos".

Ele buscará então apresentar os fundamentos do liberalismo e como ele está relacionado com as nossas concepções do que é uma boa vida.

A maioria das críticas ao liberalismo diz que dá demasiada atenção aos princípios de justiça (o correto) e pouca para o valor da vida que as pessoas podem ter (o bem). $\mathrm{O}$ liberalismo não se comprometeria com nenhuma concepção de boa vida, mas com os princípios de justiça que regeriam essas vidas, ou seja, que definem as instituições políticas e econômicas nas quais tomamos as nossas decisões. Para Dworkin é natural essa separação, já que o traço definidor do liberalismo é que o governo de uma comunidade seja neutro em relação a diferentes concepções de boa vida, obedecendo à idéia de que todos devem ser tratados com igual consideração e respeito independente do seu plano de vida. Ele, assim como os demais liberais, não acredita em teorias perfeccionistas, que estabelecem modelos de vida a serem seguidos.

${ }^{126}$ VS: XV. 
O liberalismo também quer ser aceito pelo maior número possível de pessoas ao não escolher entre nenhuma concepção de boa vida, deixando o caminho aberto para mais e mais adeptos.

A busca de Dworkin é pela motivação da teoria do ponto de vista filosófico, onde se questiona se o liberalismo poderia considerar uma teoria mais geral de como devemos viver. Neste ponto ele identifica que a questão a ser respondida está no campo da ética e da conexão desta com a política, e que seu objetivo é evidenciar os antecedentes do liberalismo, primeiro na ética e depois na biologia, filosofia, psicologia, história e na teoria econômica ${ }^{127}$.

Para entender a essência do liberalismo, ele enuncia que:

"Liberalism is social and exciting because it insists that liberty, equality, and community are not three distinct and often conflicting political virtues, as other political theories both on the left and right of liberalism regard them, but complementary aspects of a single political vision, so that we cannot secure or even understand any one of these three political ideals independently of the others" (FLE: 194).

A sua versão do liberalismo, a igualdade liberal, expressaria essas virtudes. Ao definir que poderíamos ter um liberalismo conectando o pessoal com o político, ou seja, que deveríamos considerar a pluralidade dos indivíduos na formulação de princípios de justiça, torna-se necessário dizer como podemos medir o valor de uma vida. Precisamos de uma métrica.

A métrica a ser utilizada por Dworkin será escolhida entre dois modelos, o modelo de impacto e o do desafio. O primeiro modelo afirma que o valor de uma vida é definido pelo impacto que ela causa no mundo. O modelo do desafio determina que o valor de uma vida é determinado pela forma como cada um de nós lida com os desafios postos na vida. Aqui não interessa o resultado, mas o processo, qual seja, o processo de

\footnotetext{
${ }^{127}$ FLE: 192.
} 
enfrentamento das questões. Para Dworkin o maior desafio é viver, portanto o valor da vida é que ela seja vivida. Habilidade de lidar com o desafio de viver a vida.

Ele começa a nos apresentar a sua versão de liberalismo, com a definição que estamos familiarizados, pelo menos na sua definição norte-americana. Dworkin afirma que o liberalismo reúne algumas idéias políticas cruas e pouco refinadas. A primeira é que os liberais são "modestamente” ou moderadamente igualitários, ou seja, criticam as desigualdades e até são favoráveis a políticas de redistribuição de renda, mas impõem limites ao governo para esse tipo de política. A segunda idéia é que os liberais sacralizam alguns direitos acima de todos os demais, como o de liberdade, principalmente a liberdade de expressão, credo, direito de ser livre da discriminação e de atividade política. Isso significa que estes não podem ser sacrificados em função de qualquer outro direito. A terceira idéia é que os liberais são tolerantes em relação à moralidade pessoal, ou seja, nossas escolhas de vida. No entanto, esse conjunto de idéias soltas não constitui uma filosofia política, para isso será necessário identificar mais precisamente a igualdade, a liberdade e a tolerância expressas nas idéias acima. Que é a mesma questão levantada anteriormente. Essa busca nos leva a ter que responder perguntas como: igualdade de quê? Quais são os limites para a liberdade e tolerância? Estas perguntas, segundo o autor, estão no primeiro eixo de interpretação do liberalismo, que é o eixo político.

A teoria da justiça de John Rawls, por exemplo, busca apresentar princípios gerais de justiça política que definam o lugar da igualdade, liberdade e tolerância. O primeiro determina que certas liberdades sejam protegidas para todos e o segundo que a desigualdades toleráveis serão aquelas que melhorarem a situação do pior posicionado na escala social. Mesmo sendo abstratos, eles definem “as regras do jogo” para a intervenção do Estado. Para Dworkin,

“(t)his is a political interpretation, because the principles, though more general and abstract and systematic than the unrefined ideas, are nevertheless plainly political principles. They state comprehensive standards for the use of coercive political power." (FLE: 198). 
Um segundo grupo de questões são aquelas que buscam encontrar o vínculo dessa concepção de justiça com nossas outras crenças, ou seja, que tenham coerência com a economia, psicologia e metafísica. Este seria o eixo de interpretação filosófico da teoria. Dworkin desenvolverá a interpretação filosófica para construir, reformar e ajustar a interpretação política.

Os dois eixos estão conectados e juntos formam uma filosofia política. Em FLE ele vai fazer uma interpretação filosófica do liberalismo em busca dos seus fundamentos. Mas esta busca se concentrará no ramo da ética, conforme definimos anteriormente, e não da economia ou psicologia porque, segundo ele, é naquele campo que os "problemas fundacionais do liberalismo são mais evidentes e urgentes”. ${ }^{128}$

Esses problemas viriam da tensão entre a perspectiva pessoal e a perspectiva política, ou entre a ética e a filosofia política. Ele define perspectiva como um conjunto de idéias ou atitudes específicas para determinadas circunstâncias, não aplicáveis em outras. A pessoal é quando essas idéias e atitudes são aplicadas à nossa vida pessoal. A política, como já podemos imaginar, são aquelas idéias para a comunidade política quando decidimos em quem votar, qual política apoiar, e não decisões em qual faculdade estudar, por exemplo. A questão é que o liberalismo exige que estas "idéias e atitudes” sejam distintas para as duas esferas da nossa vida.

A ética nos ensina que ideais ou projetos deveríamos possuir e estariam, volta e meia, submetidos à moralidade. Do outro lado, a filosofia política é o resultado da perspectiva política, já que a moralidade nos dá quais as regras que devemos aceitar como parte de uma comunidade política. Aqui Dworkin afirma que a nossa perspectiva política não deveria se chocar com a pessoal, ao contrário, deveria levar em conta a forma como agimos na vida privada, ou ainda, derivar dela.

${ }^{128}$ FLE: 199. 
Mas como compatibilizar as duas perspectivas se a pessoal não é imparcial e neutra como a política deve ser e o liberalismo exige?

"Only a zombie, we think, would be neutral about the good life in the decisions he made for others as well as himself, and only a monster would find no more demand in the pain of his child than the cry of a stranger.” (FLE: 201).

O liberalismo entendido desta forma é para Dworkin uma esquizofrenia moral e ética porque exige que sejamos pessoas diferentes numa esfera e na outra. Exige que sejamos neutros numa decisão política que favoreça minhas convicções e meus afetos.

Em seu livro mais recente, Dworkin (2006a) ${ }^{129}$ discute várias questões controversas à luz dos princípios da igualdade liberal que ele chama neste trabalho de "princípios ou dimensões de dignidade”. No capítulo sobre a religião, ele destaca que alguns americanos não separam suas convicções religiosas das políticas:

\begin{abstract}
"Americans of that opinion cannot separate these religious convictions from their political principles. Their religious convictions are political principles. They do not accept private observance as a substitute for public religious endorsement; they want to celebrate their god not just as private worshipers but as citizens. They want to pour their faith into their patriotism so that the two commitments are one” Dworkin (2006a: 64).
\end{abstract}

Todo o argumento de Dworkin é que o projeto de Rawls de um liberalismo político, que separa as convicções políticas das convicções éticas, religiosas e morais é

\footnotetext{
${ }^{129}$ Este livro é para um público mais amplo e tem como objetivo levar a mais pessoas como os princípios de dignidade podem ser aplicados em várias questões que ocupam espaço no debate político americano. Sua preocupação é com uma sociedade cada vez mais polarizada (entre democratas e republicanos) e cada vez mais desigual. O argumento no capitulo citado é que o principio da responsabilidade pessoal requer um estado secular tolerante e não um estado religioso tolerante. No primeiro, é tolerante com as religiões, mas não endossa nenhuma delas e é neutro em relação a qualquer religião. $\mathrm{O}$ estado é laico e não há referências religiosas nas suas cerimônias oficiais. $\mathrm{O}$ estado religioso tolerante endossa a religião como uma força positiva para a sociedade.
} 
limitado. Seu projeto é encontrar um debate genuíno que não exclua essas convicções do debate político.

Como resolvemos esse impasse? Ele propõe analisar as críticas dirigidas a esta exigência do liberalismo vindas dos comunitaristas como forma de começarmos a identificar os fundamentos do liberalismo. Dworkin não acredita na existência desse conflito entre a ética e o liberalismo, mas os comunitaristas seriam um atalho mais rápido, já que nos aproximariam da política e não da metafísica.

Existem duas estratégias que podemos utilizar para a reconciliação entre as duas perspectivas: a contínua e a descontínua. A estratégia utilizada por Rawls e outros filósofos liberais é a descontínua. Esta estratégia nos diz que a perspectiva política é artificial, ou seja, uma construção social e suficientemente geral para permitir que a pluralidade das perspectivas pessoais não impeça que seja aceita por todos. É como um contrato, artificial, no qual as pessoas, mesmo com diferentes visões de mundo, concordam em alguns termos gerais. O contrato deriva da perspectiva pessoal, mas não deve ser entendido como um espelho da mesma, daí a descontinuidade. O contrato de Rawls é o exemplo dessa estratégia.

Para Rawls, prossegue Dworkin, a teoria da justiça é uma concepção política da justiça na qual as divergências de concepções de vida e de ética não afetam, e parecem não influir, na construção da estrutura básica das instituições políticas. Uma boa vida para Rawls deve estar comprometida com a justiça, no entanto o argumento de Dworkin é que a justiça é ad hoc, ou seja, não se origina das concepções éticas de uma comunidade em particular, mas é determinada pelo filósofo que a concebe. Seria uma grande coincidência ter a justiça como valor em todas as perspectivas. Podemos complementar dizendo que o contrato é um acordo que se dá entre pessoas livres, iguais e com perspectivas pessoais distintas.

A segunda estratégia é a contínua, que oferece diferentes fundamentos para o liberalismo. Nesta estratégia as nossas convicções políticas estariam à altura das 
convicções pessoais ou éticas. A estratégia contínua busca construir a "ética liberal" através da integração das duas perspectivas e, ao mesmo tempo, manter a neutralidade do liberalismo em relação às concepções de boa vida. A forma de se fazer isso é termos uma ética liberal abstrata, que nos dá uma estrutura, e não detalhar o que seria uma boa vida.

Dado que a abordagem de Dworkin é o ponto de vista filosófico, essa ética deverá ter esse caráter estruturante e filosófico, e não substantivo, como ele mesmo alerta. Este é um ponto importante porque ajuda a entender o que mais adiante será apresentado como métrica do valor ético de uma vida. Para que o liberalismo mantenha sua neutralidade, o autor vai oferecer uma ética abstrata que vai se basear não no resultado, mas na habilidade e na realização de seus objetivos. A ética proposta deve ser liberal de modo que a pluralidade de indivíduos da comunidade tenha maior probabilidade de adotar um ponto de vista político liberal. A ética liberal deverá ser capaz de passar pelos dois testes acima, o de abstração e da capacidade discriminante.

As duas estratégias têm um ponto comum, o de mostrar como pessoas com concepções de vida distintas podem estar de acordo com uma estrutura política liberal única. Mas na estratégia contínua não "deixamos de lado” as nossas convicções pessoais quando estamos tratando do campo da política. Quando as incorporamos é que surge a política liberal na sua plenitude, daí que a ética e a política se interelacionam e se conectam de tal forma que certas questões ${ }^{130}$ sobre a boa vida também são políticas. Outra diferença entre as duas estratégias é que, para a estratégia da descontinuidade, a neutralidade é um axioma que é incorporado desde o início, mas na estratégia da continuidade, a neutralidade é alcançada na construção do argumento.

\footnotetext{
${ }^{130}$ Estas questões não são definidas, mas podemos inferir que seriam as mais abrangentes e filosóficas sobre o que é a boa vida.
} 
"It hopes that the liberal ethics it constructs will not only appeal to people who have very different substantive views of good life, but also provide reasons why each of them should be tolerant of the others" (FLE: 209).

Portanto, a escolha entre as duas estratégias é a escolha entre duas formas de liberalismo.

O contrato social é um exemplo da estratégia da descontinuidade e as pessoas buscam adotá-lo porque desejam alcançar algum acordo sobre as instituições políticas básicas. Quais as razões para se deixar as conviçcões pessoais de lado para aceitar esse tipo de contrato?

Se entendermos a perspectiva pessoal como uma combinação de instintos, intuições e convicções de dois ramos da ética, o bem-estar e a moralidade, podemos dizer que nos contratos comerciais as pessoas perseguem seu próprio bem-estar, mas no contrato social isso também seria verdade? Segundo Dworkin, a teoria de Rawls se desviaria das teorias contratualistas clássicas de Locke e Hobbes porque, além de interesses no sentido estreito, de busca de seu próprio bem-estar, incluiria outro ramo da ética, a moralidade, ou uma concepção do que é uma boa vida. Acredito que Dworkin esteja evidenciando aqui a diferença importante que o contrato de Rawls tem em relação ao de Hobbes. Na construção da teoria da justiça, Rawls recuperou a tradição contratualista que estava esquecida. Na teoria do contrato de Hobbes as pessoas aceitam o contrato baseadas no interesse próprio e não existe nenhum constrangimento moral como os direitos dos outros.

"The Hobbesian social contract is a rational compromise among essentially conflicting interests, where all parties agree to cooperate by observing certain reasonable constraints on condition that others abide by them too, in order that all may effectively pursue their own interests." Freeman (2007:15).

Rawls incorpora parte da teoria de Hobbes ao assumir que as partes na "posição original” fazem uma escolha racional baseadas no interesse próprio, mas o "véu de 
ignorância” também incorpora algumas condições morais. Ou seja, na escolha dos princípios as partes não serão influenciadas pelo interesse próprio, já que não sabem o que serão, qual posição social, suas habilidades, etc. Essas partes agirão da forma mais avessa possível ao risco, por isso chegam ao "princípio da diferença”. O autor não aceita que as pessoas são motivadas apenas pelo interesse próprio que é uma diferença importante em relação a Hobbes. Se ele conseguir evidenciar uma razão moral, estaria avançando sobremaneira em relação às demais teorias contratualistas, que apelam apenas para o bem-estar individual e o interesse próprio.

Dworkin afirma que para que o contrato social seja aceito é preciso uma "força categórica”, mais do que um consenso. Significa dizer, as pessoas reais teriam uma razão moral para aceitar as decisões que endossam uma concepção liberal de justiça, mesmo que não o tenham endossado de forma coletiva.

Ao considerarmos a moralidade como uma razão para adotarmos um contrato, como ela vai permitir a parcialidade na vida pessoal e não na vida coletiva? O autor diz que não há nada de injusto ou errado em ajudar as pessoas que são mais próximas ou que compartilham os mesmos valores. Ou ainda votar por políticas públicas que vão ao encontro de minhas convicções. Para ele, na vida ética cotidiana, a moralidade da equidade vai refletir os compromissos com a vida boa ${ }^{131}$.

Para Rawls, as instituições, princípios e ideais estão implícitos ou latentes na cultura de uma sociedade democrática e, a partir dai, agrupamos essas idéias numa concepção coerente de justiça. Com este perfil, afirma Rawls, a concepção liberal de justiça formada terá mais chances de alcançar o consenso. Ela não aparece desgarrada da vida privada de cada um, ao "pinçar" aquilo que já adotamos na nossa vida pública. Dworkin se preocupa com a idéia de que o conceito de princípios "latentes” sejam suficientes para dar força categórica ao contrato social rawlsiano. Segundo ele, podemos dizer que princípios latentes nas tradições de uma comunidade são aqueles

${ }^{131}$ Ver Scanlon (1982). 
que melhor interpretam os acontecimentos da história da mesma. Mas o problema é que parece pouco provável que consigamos considerar todas as tradições e idéias de uma comunidade, e a conseqüência seria que o utilitarismo poderia se encaixar melhor em algumas situações que a justiça como equidade. O que Rawls e o próprio Dworkin combatem. As controvérsias na cultura continuarão a existir, por isso Rawls propõe que as concepções políticas de justiça equivalentes se enfrentem para que possamos escolher a que melhor se ajusta àquela comunidade. Dworkin é taxativo e afirma que esse tipo de solução não tem nada a ver com força categórica. Como decidir entre duas concepções? A mais justa? Neste caso, precisaríamos de uma terceira concepção ou teoria da justiça. Portanto, a solução de Rawls não é útil para responder como uma concepção política de justiça eleita através da estratégia da descontinuidade possui força categórica, ou, em outras palavras, como a pluralidade das pessoas nos levaria a um contrato social.

Dworkin afirma que o problema de escolher o que está latente já exige que tenhamos em mente alguma concepção de justiça tal que sua força categórica seja defendida de outra forma. Assim, o liberalismo de Rawls não consegue reconciliar as duas perspectivas, já que a moralidade não é independente da ética, ao contrário, está integrada a ela. A estratégia da descontinuidade nos exige uma perspectiva política especial e austera para a política, separada da nossa perspectiva pessoal, o que para Dworkin não faz sentido. Diante deste resultado, seu objetivo é nos oferecer uma versão do liberalismo capaz de oferecer essa força categórica, a igualdade liberal, que apresentamos a seguir.

Ele afirma que a igualdade liberal se diferencia em vários aspectos da justiça como equidade. Na igualdade liberal, a distribuição ideal da propriedade se dá quando os recursos que as pessoas controlam são iguais nos custos de oportunidade, ou seja, no valor que teriam nas mãos de outras pessoas. A igualdade é alcançada quando ninguém 
inveja $^{132}$ a cesta de recursos que cada um possui, onde os custos de oportunidade são iguais. Chegaríamos a esta situação via leilão no qual cada uma das pessoas teria a mesma quantidade de "fichas" ${ }^{133}$ para serem utilizadas. O leilão ocorreria até que todos chegassem a um cesta de recursos e não invejassem a de outrem.

O leilão não será perfeito porque temos recursos que não podem ser leiloados ou transferidos. Os recursos pessoais como talento, habilidades, cor dos olhos, altura, metabolismo $^{134}$ são características que não estão disponíveis para redistribuição. As impessoais, como terras, casas, objetos, são os únicos recursos que podem participar do "mercado". Ao fim do leilão, ${ }^{135}$ quando começarmos as trocas e a interação, os talentos e demais recursos pessoais eliminarão qualquer igualdade nos recursos impessoais. Dworkin afirma que a igualdade liberal não pode prescindir de uma compensação para as desigualdades pessoais. Ele acrescenta que as pessoas estão sujeitas a situações de sorte ou azar. O meu negócio pode não prosperar e falir, pondo a perder meus recursos impessoais. Diante dessas situações, fora de controle das pessoas, a igualdade propõe que sejamos compensados, mas o princípio da responsabilização das nossas decisões permanece e, neste caso, não teríamos o benefício da redistribuição de recursos.

\footnotetext{
132 A inveja aqui não é utilizada no seu sentido psicológico, mas no sentido econômico ao fazer referência às preferências das pessoas. Quando as preferências estiverem satisfeitas, ou seja, os custos de oportunidade estiverem igualados, a distribuição de recursos é a ideal.

${ }^{133}$ Neste texto sobre a igualdade de recursos, Dworkin não utiliza a metáfora das pessoas isoladas numa ilha com a mesma quantidade de conchas. Isso é feito no texto anterior "What is Equality" que foi reunido na VS. Na Tanner Lecture, sua preocupação é com os fundamentos da sua versão do liberalismo e menos em explicitar os detalhes do leilão ou das suas criticas ao utilitarismo. Na seção seguinte, vamos nos deter no leilão e na distribuição dos recursos.

${ }^{134}$ Amartya Sen apresenta sua crítica às teorias de justiça distributivas afirmando que elas dão muita atenção aos meios e não aos fins, e que justamente muitas pessoas possuem diferentes capacidades de conversão dos recursos em bem-estar ou satisfação pessoal. Ele propõe que busquemos a igualdade nas capacidades como forma de reduzirmos a desigualdade.

${ }^{135}$ Dworkin utiliza o mercado para alcançar a igualdade de recursos. Ele mesmo afirma que ele não é perfeito, visto que temos os recursos pessoais que não podem ser comercializados, mas é o melhor instrumento de alocação de recursos, desde que sujeito à regulação e ajustes.
} 
A liberdade está implícita na forma como os recursos são distribuídos, visto que todos devem entrar em condições iguais e livres no mercado. Para Dworkin, não poderia ser diferente:

\begin{abstract}
"Since liberal equality depends on economic and political devices that reveal the true opportunity costs of impersonal resources, an egalitarian society must be a free society. Invasions of liberty criminal laws prohibiting activities or ways of life some people might wish to take up, for example - are invasions of equality as well, unless they can be justified as necessary to protect an egalitarian distribution of resources and opportunities by providing security of person and property or in some other way." (FLE: 224-5).
\end{abstract}

O estado não pode criar leis que proíbam atividades ou comportamentos baseando-se na moralidade pessoal, já que também atingiria a igualdade e principalmente o princípio de que todos devem ser tratados com igual consideração e respeito. Portanto, a igualdade liberal preserva um dos pilares do liberalismo mencionado anteriormente, que é a tolerância.

Podemos dizer que as características da igualdade liberal são quatro: a primeira é que pressupõe a separação clara entre personalidade e circunstância. A igualdade liberal busca a igualdade nas circunstâncias, ou seja, nos recursos, sejam pessoais ou impessoais. No entanto, cada indivíduo é responsável pelas suas decisões e escolhas, pelos projetos e desafios que deseja enfrentar, portanto o bem-estar não é igual. A igualdade liberal não tenta igualar as personalidades ou concepções de boa vida, mas os meios passíveis de distribuição, para alcançá-las. A conseqüência disso é que nossas escolhas não podem ser usadas como justificativa para termos mais recursos. Se gostarmos mais de champanhe do que de suco de maçã é uma questão pessoal e os demais não deverão pagar por isso, ou seja, não haverá via impostos distribuição de mais recursos para esse gosto caro ${ }^{136}$.

\footnotetext{
${ }^{136}$ A não compensação de gostos caros e o caso de deficiências serão explorados mais adiante já que é um dos pontos mais importantes da teoria de Dworkin e que o distingue da justiça como equidade de Rawls. Adicionalmente, há a questão, não totalmente respondida por Dworkin, dos casos em que, na verdade, não necessariamente controlamos nossos gostos e que podemos apenas gostar de coisas caras.
} 
A segunda idéia, derivada da primeira, é que a igualdade liberal não utiliza o bem-estar como métrica para a justiça. A métrica utilizada são os recursos, mas não podemos imaginar que desejamos os recursos por si mesmos. Eles têm uma função clara, qual seja, permitir que realizemos nossas concepções de boa vida. Por isso, não faz sentido igualar as pessoas no resultado, ou seja, o bem-estar, mas nos recursos que cada um possui. Para entendermos o papel dos recursos, vale mencionar a crítica que Dworkin faz à concepção de Amartya Sen, a igualdade de capacidades. Segundo Sen, Dworkin estaria confundindo meios com fins ${ }^{137}$. Mas a resposta de Dworkin é que as pessoas sãs desejam os recursos para atingir seus objetivos e satisfazer seus desejos e não os recursos em si. Se os recursos são confundidos com os fins, as pessoas seriam fetichistas patológicas. ${ }^{138}$

A terceira é que a justiça não é apenas uma questão de recursos, mas de igualdade de recursos. A quarta é a tolerância, já citada anteriormente, na qual o governo deve ser neutro e não basear-se em nenhuma concepção de vida boa. Diferente da estratégia da descontinuidade, da qual derivamos facilmente a neutralidade, na estratégia contínua isso se torna mais difícil. Como explicar que a neutralidade surge do compromisso ético sem a necessidade de um contrato?

Para responder essa questão, Dworkin apresenta dois tipos de interesses: os volitivos e os críticos. Somente poderemos inferir o quão boa é uma vida se tivermos uma métrica e será por este caminho que vamos apresentar a forma como a estratégia contínua resolverá a questão.

O nosso bem-estar (do tipo) volitivo aumenta quando conseguimos o que desejamos. O bem-estar (do tipo) crítico aumenta se conseguimos aquilo que deveríamos desejar caso contrário a vida fica pior. O exemplo dado pelo autor para o primeiro tipo é

Dado que a compensação se dá em situações não escolhidas pelos indivíduos, a igualdade liberal não responde exatamente à linha divisória dos gostos cultivados e os involuntários.

${ }^{137}$ Ver capítulo 7 de Dworkin (2005).

${ }^{138}$ FLE: 227. 
quando desejamos velejar bem. O fato de não saber velejar tão bem não faria nossa vida pior objetivamente. ${ }^{139}$ Mas se eu não conseguir ter um bom relacionamento com meus filhos, isso pioraria a minha vida, sendo então um interesse crítico e não volitivo.

Para encontrarmos uma ética liberal como fundamento para a política devemos nos concentrar no bem-estar crítico e precisamos, portanto, de uma descrição de como as pessoas partem de seu próprio bem-estar para a política na sua forma liberal. A razão é que os princípios políticos são normativos como os interesses críticos. Queremos saber, afirma Dworkin, se aqueles que levam a sério seus interesses críticos seriam motivados a adotar a perspectiva política liberal.

Os modelos de valor ético são interpretações da experiência ética e formas de organizar nossas intuições éticas, mas nos ajudarão a responder alguns dos quebracabeças que surgem em torno do caráter da ética.

O primeiro é o modelo de impacto, onde o valor de uma vida consiste no seu produto final, nas suas conseqüências sobre o mundo. Ele tenta ligar o valor ético com o valor de situações objetivas do mundo, e a vida é mais valiosa pelas conseqüências dos nossos atos.

O outro modelo é o de desafio, no qual o valor da vida está não no resultado, mas no processo, no ato de lidar com os desafios da própria vida da forma mais habilidosa possível. Viver bem é responder da forma correta ao desafio correto. Para Dworkin, esse modelo adota o ponto de vista aristotélico de que uma boa vida tem seu valor no exercício de viver com destreza.

"The model of challenge holds that living a life is itself a performance
that demands skill, that it is the most comprehensive and important
challenge we face, and that our critical interests consist in the
achievements, events, and experiences that mean that we have met the
challenge well." (FLE: 244).

${ }^{139}$ Aqui não assumimos que ele seja um atleta da vela. Se fosse, não velejar tão bem realmente tornaria sua vida pior. 
Mas o que significa viver bem na concepção dworkiana? Significa que nós devemos nos identificar com os objetivos, desafios e planos. A isso ele denomina "integridade ética”:

\begin{abstract}
"Someone has achieved ethical integrity, we may say, when he lives out the conviction that his life, in its central features, is an appropriate one, that no other life he might live would be a plainly better response to the parameters of his ethical situation rightly judged. A person who identifies with a different feasible lifestyle to the one he leads lacks ethical integrity, and, no matter how well he pursues the activities of his life, they fail to benefit him, because ethical integrity is a necessary condition of living well." Clayton $(2002,15)$.
\end{abstract}

Segundo, não basta se identificar com o desafio é preciso que cada um de nós o tenhamos escolhido, caso contrário a vida não terá valor. Dworkin é um filósofo americano que tem participação ativa nos debates sobre questões controversas da vida de seu país, um exemplo é sua análise sobre o que deve ser ensinado para as crianças sobre a criação do mundo: evolucionismo ou o creacionismo. A base da sua argumentação é justamente o conceito de viver bem, qual seja, que não podemos ser obrigados a acreditar em algo que não queremos e que para a escolha ser livre e voluntária, precisamos ter as informações necessárias para exercê-la.

"But the dignity we should try to preserve for all citizens does not
simply command that no one be forced to recite what he does not
believe. It assigns each of us a positive responsibility to choose ethical
values for ourselves, and though we know we are influenced by
thousands of dimensions of culture in making those choices, we must
nevertheless refuse to accept subordination to a government that
deliberately and coercively manipulates our choices". Dworkin
(2006c) Uma das razões apontadas para a adoção do modelo de desafio é que, ao contrário do de impacto, que estaria ligado ao valor de situações objetivas do mundo, ele desvinculado desses valores objetivos. Parece dar mais liberdade para a concepção de 
boa vida, já que podemos pensar em qualquer coisa que julgamos ser bem viver sem necessariamente esperar que tenham algum valor objetivo. ${ }^{140}$

Uma forma de justificar a escolha é a maneira como esses modelos respondem as questões colocadas a seguir:

Qual o significado da vida? Os interesses são transcendentes ou indexados a uma cultura, comunidade, etc? Podemos julgar nossa vida segundo uma concepção aditiva ou constitutiva?

Para a primeira questão, a resposta crítica dada ao modelo de impacto é que ele produziria uma ética utilitarista, de forma que o valor da vida estaria no prazer gerado para o indivíduo e para os outros. Já no modelo de desafio, o valor ético não depende de nenhum valor objetivo pessoal ou coletivo. Este modelo, ao evitar o valor das conseqüências de algum êxito, como uma pintura, evita que a vida tenha valor apenas para gênios das artes ou grandes atletas como faz o modelo de impacto. Só no fato de enfrentar as circunstâncias corretas, da melhor forma possível, a vida já tem o seu valor.

\footnotetext{
"What matters then is a particular kind of performance and not merely the outcome, considered independently of the performance, that is produced by one's life. And Dworkin insists that the motives from which one acts are relevant to the evaluation of that performance." Clayton (2002:15).
}

Poderíamos questionar que o modelo de desafio exige que sejamos heróis, façamos coisas dignas de manchetes de jornal, mas, ao contrário, ele não pretende tal coisa. Ele apenas afirma que devemos encarar a vida como um desafio, um exercício, e vincular o seu valor ao processo de enfrentamento e não ao produto final.

\footnotetext{
${ }^{140}$ Arneson in Burley (2004) afirma que a implausibilidade do modelo de impacto não significa a plausibilidade e aceitação do modelo do desafio. Para o autor, nenhum dos dois modelos seria suficiente como modelo de valor ético, por deixarem uma série de situações de fora, ao não capturarem a noção de uma vida verdadeiramente boa. Para ele, a escolha pelo modelo do desafio como o melhor não é clara.
} 
"Seeing ethical value as the value of a performance rather than as tied to the independent value of a product allows a further range of considerations and beliefs to enter ethical judgment, though it does itself select among any particular set of these as more appropriate than others" (FLE: 249).

O trecho acima mostra como Dworkin começa a desenhar a sua versão do liberalismo que também é neutra em relação a quaisquer concepções de boa vida. O modelo de impacto parece não garantir essa neutralidade, uma vez que é preciso definir o que tem valor objetivo. Nisso o modelo de desafio não interfere, ao apenas indicar que o plano de vida escolhido e enfrentado terá valor. Adiante ficará mais claro, porém já foi citado no início que um dos pontos fundamentais da igualdade liberal é a responsabilidade dos indivíduos na escolha de seus desafios. Cada um escolherá um objetivo de vida, o que ele considera importante e o que o fará feliz e realizado. Para a busca desses objetivos vamos enfrentar circunstâncias que poderão nos ajudar ou nos prejudicar. O papel da igualdade liberal será nos igualar nas circunstâncias, mas teremos que assumir as escolhas feitas, seja por uma vida frugal ou uma vida dispendiosa e perdulária. Para essas escolhas a teoria, como já foi dito, não oferece compensação.

Na segunda questão, o modelo de impacto nos diz que o valor ético é transcendente visto que, ao vincular-se um valor objetivo, torna-o independente do contexto em que se encontra. O valor deve ser o mesmo em quaisquer situações, época ou comunidade. Já no modelo de desafio o contexto, tempo, cultura, influenciarão o nosso plano de vida, dando fortes indicações que o valor ético é indexado.

O autor usa a arte para nos explicar melhor essa relação. A arte não tem um valor artístico em todas as épocas, não existe apenas uma forma de criá-la. Para o valor da vida seria a mesma coisa. Uma vida pode ter valor numa época, num determinado contexto. Outra razão para pensarmos que o valor ético é indexado é que os parâmetros que enfrentamos na vida, sejam eles legais, culturais, variam com o tempo, e por isso, o nosso desafio pode se tornar maior ou menor em virtude dessas mudanças. 
Antes de continuarmos a responder as questões colocadas, precisamos definir o que estamos querendo dizer com circunstâncias da vida ou circunstâncias corretas.

Podemos dizer que existem dois tipos de circunstâncias: os parâmetros e as limitações. Os parâmetros podem ser nossos talentos, recursos, gostos, regras, desejos sob os quais vamos nos orientar para viver. Eles descrevem as condições para o êxito de um exercício. Ainda, os parâmetros podem ser classificados entre duros e brandos. A violação de um parâmetro duro aniquila a execução de uma ação: usando o exemplo do autor, quando não usamos a estrutura correta para um soneto, este deixa de sê-lo. No caso do parâmetro brando, não aniquilamos a execução da ação, apenas reduzimos o valor da ação. O exemplo agora são os movimentos obrigatórios de uma competição de ginástica, não executá-los não impede que a apresentação seja bela e ganhe pontos, mas é uma falha. Dworkin afirma que para a maioria de nós os parâmetros que definem o êxito da vida são os brandos.

Existem também os parâmetros normativos que definem a "situação ética" de execução dos desafios escolhidos por cada um. Podemos incluir como parâmetros normativos a religião, os hábitos da comunidade, entre outros.

As limitações, de outra parte, são todas as situações que dificultam ou impedem a realização de um objetivo ou tarefa podem ser a falta de recursos, deficiência física, etc ${ }^{141}$. Como ficam os modelos diante dos parâmetros e limitações?

No modelo de impacto todas as circunstâncias da vida de uma pessoa são consideradas limitações, já que, segundo Dworkin, nesse modelo, a vida real é sempre a mesma, o valor é o mesmo. Se o objetivo é o máximo valor que uma vida pode alcançar, as circunstâncias são sempre limitadoras. No entanto, no modelo do desafio podemos dizer que temos parâmetros e limitações, dada a própria definição de valor ético que o

\footnotetext{
${ }^{141}$ Questões sobre deficiência, gostos dispendiosos, talentos, são temas que exploraremos com mais profundidade quando apresentarmos a igualdade de recursos de Dworkin com seus mecanismos de distribuição e compensação.
} 
modelo nos apresenta. O valor ético está no desafio de uma tarefa, assim, circunstâncias diferentes produzem desafios diferentes.

Essa discussão é apenas para dizer que se aceitamos o modelo de desafio, não podemos deixar de classificar a justiça como um parâmetro normativo, ou seja, a vida não será virtuosa se for injusta. Significa dizer que viver bem é responder da maneira correta o desafio correto e, se não considerarmos a justiça como parâmetro, não teremos uma vida boa, já que o desafio não é correto. A justiça entra como um parâmetro ético brando para viver bem, porque uma vida poderá ser boa mesmo assim. Um dos exemplos do autor é o caso de uma criança muito doente cujo tratamento é financiado pela renda elevada injusta que os seus pais possuem. A vida da criança foi salva e ela vive muito bem.

Dworkin incorpora à teoria a idéia de Platão de que não há vida boa sob bases injustas $^{142}$, assim não haveria um conflito entre a justiça e o interesse próprio, porque não podemos ter uma boa vida cometendo atos injustos. Ele avança dizendo que não temos outra alternativa senão considerar que uma boa vida é aquela na qual enfrentamos as circunstâncias adequadas, estas entendidas como uma distribuição justa de recursos. Não faz sentido deixarmos de lado o papel dos recursos, já que definimos que uma boa vida é responder de forma adequada a um objetivo adequado. O ponto é importante porque reforça que os recursos são meios para se alcançar objetivos que foram definidos pelos indivíduos e não fins em si mesmos.

A idéia platônica de que não há conflito entre justiça e interesse próprio também é usada por Dworkin para responder à pergunta se as pessoas não poderiam ter uma vida melhor com mais recursos. A resposta de Platão, e de Dworkin, seria que a vida de nenhum cidadão poderá melhorar se ele possuir mais recursos do que aquela quantidade definida como justa.

\footnotetext{
${ }^{142}$ Arneson in Burley (2004) diz que não podemos assumir que sempre teremos uma vida pior sob situações injustas. "What I find unpersuasive is the claim that living circumstances of injustice is always per se a grave misfortune for any person, regardless of such contingencies and quite independently of that person's own evaluative convictions on these matters.” (Burley, 2004: 85)
} 
"So once we identify the conditions of a really good life for us, in a clearhead way, we will have some sympathy with Plato's view that justice is a hard parameter of ethics, that nothing can redeem a life spoilt by the misfortune of living in an unjust state." (FLE: 261)

A idéia platônica de que não podemos ter uma vida melhor se tivermos circunstâncias injustas é, para o autor, a forma de defesa mais forte da igualdade liberal. No seu texto original não está explícito, mas no seu livro mais recente, ele declara a importância daquela idéia:

“(...) quero demonstrar o apelo ético da tese platônica de que a justiça e a bondade não podem entrar em conflito, e como essa tese proporciona uma defesa especialmente forte, não só do liberalismo em geral, mas da igualdade liberal como a melhor concepção do liberalismo." (VS:337)

A discussão sobre parâmetros e limitações é fundamental para entendermos o liberalismo de Dworkin, já que se alguém possuir recursos numa quantidade injusta estará enfrentando o desafio errado, e nada que ele alcançar na vida poderá compensar esse erro.

Mas o uso da justiça como parâmetro garante que a igualdade liberal, expressa na igualdade recursos, seja a melhor alternativa de justiça?

Clayton (2002) questiona como a noção de viver bem, que requer uma quantidade de recursos justa, apóia a idéia de que a igualdade liberal é a melhor versão para a justiça. Ele entende que, ao definirmos a justiça como parâmetro da ética, não podemos ter uma boa vida sem fazer referência à justiça. É a idéia platônica mencionada anteriormente. A posse de recursos pode não nos trazer uma vida boa se a parcela for injusta, para mais ou para menos.

"Thus conceptions of justice that proceed from a conception of wellbeing defined without reference to norms of justice, and then theorize justice as, say, equal access to well-being, mistakenly suppose that 
our interests can be defined independently of an assessment of what justice demands. Similarly, our humanist's proposal, that we can distribute resources in a manner that encourages individuals away from unworthy pursuits into worthy ones, errs in supposing that we can identify what would be good for people independently of identifying what a fair share of resources would be." Clayton (2002:19).

Viver bem não está separado da noção de justiça e, ao tornar a justiça um parâmetro da ética, a igualdade liberal apela a intuições sobre o que é a justiça sem definir o que é bem-estar. Veremos mais adiante as razões de Dworkin para não aceitarmos o bemestar como métrica da justiça. O modelo do desafio tem uma noção abstrata de bemestar $^{143}$, que pede por uma distribuição igualitária de recursos como parâmetros. Para Dworkin, a neutralidade ética é importante para sua noção de justiça e a igualdade de recursos é a melhor alternativa, visto que não nos atrela a nenhuma concepção de boa vida, e muito menos a uma concepção de bem-estar. Os recursos aparecem como parâmetros para o desafio que cada um deverá escolher e se identificar. A justiça se encaixaria no problema de como esses parâmetros serão definidos e não como aquilo que determinará o tipo de vida que deveremos levar.

"Justice connects continuously with our personal ethics by limiting
the amount of resources a person may have to live a critically good
life. It achieves that connection by respecting others as equals since
the measure of resources is its true cost to other people. (...) Justice
affects my private space by setting major parameters around that
space and the way I live is colored by the justice of the freedom that is
distributed to me." Guest (1997: 250)

Outra forma de garantir a qualidade do desafio é entender que as convicções devem passar por análise e reflexão e não devem ser “implantadas” ou recortadas e colocadas

\footnotetext{
${ }^{143}$ Clayton (2002) é mais cético em relação à afirmativa de Dworkin que devemos ter uma noção altamente abstrata de bem-estar quando estamos falando de justiça. Ao colocar a justiça como parâmetro ético, não há razão para termos a métrica da justiça igualitária como eticamente neutra. Um perfeccionista poderia pedir pela igualdade de oportunidade para poder enfrentar os desafios, utilizando o que o próprio Dworkin diz sobre os desafios, de que estes teriam mais valor se a vida for mais excitante, diversa, complexa e criativa, via igualdade no acesso a educação e informação. Isso poderia nos levar a subsidiar formas de vida. Ou seja, a ideia de que a justiça é um parâmetro não garantiria que a igualdade de recursos seria a melhor alternativa.
} 
numa lista finita de escolhas. Novamente, esse seria um tipo de paternalismo nocivo ao modelo de desafio que Dworkin adota. Devemos poder inclusive revisar as nossas convicções se acharmos que elas são inadequadas, daí o papel da educação e do acesso às informações.

Ainda nos resta responder a relação entre as nossas convicções e a boa vida, se é aditiva ou constitutiva. No modelo de impacto a relação é mais aditiva do que constitutiva, ou seja, uma somatória de situações objetivas da vida que têm valor independente das nossas convicções. No modelo do desafio, a resposta é inversa, são as nossas convicções que determinam se algo tem valor para a vida ou não, portanto a relação é constitutiva ${ }^{144}$. Como podemos enfrentar um desafio ou um projeto se não achamos que tenha valor? As nossas convicções possuem um papel fundamental no modelo do desafio, mas no modelo de impacto elas parecem ser apenas acessórias e não determinantes do valor da vida.

A última questão a ser respondida é sobre a unidade do valor ético, se é pessoal ou coletiva. No modelo de impacto o valor está no impacto do indivíduo no mundo e na comunidade como um todo, portanto o valor ético é pessoal. No modelo de desafio, as nossas convicções fazem parte de um exercício coletivo, elas são influenciadas pela comunidade na qual estamos inseridos. Significa dizer que neste modelo de desafio não podemos estar descolados da comunidade, por isso o valor ético é coletivo. Mais adiante veremos como Dworkin trata da relação entre o indivíduo e a comunidade. ${ }^{145}$

\footnotetext{
${ }^{144} \mathrm{O}$ modelo do desafio parece negar o paternalismo, mas Dworkin responde que o paternalismo coercitivo do Estado não seria de caráter critico, mas do tipo volitivo. O exemplo clássico é a obrigatoriedade do uso de cinto de segurança que ele chama de "paternalismo superficial”. Ele não concorda com a idéia de que o Estado é obrigado a atuar também contra as nossas convicções, num sentido critico. O modelo de desafio, nas suas próprias palavras, desconfia do paternalismo crítico justamente porque este acredita que uma vida pode ser melhorada forçando uma situação que o individuo não crê que tenha valor. Ele não exclui todo o tipo de paternalismo apenas requer que a aceitação seja genuína e não forçada. O tema paternalismo poderia ser discutido mais amplamente em outro texto. Sobre essa questão, ver Wolfe (1994) e o capitulo em VS sobre a comunidade liberal.

${ }^{145}$ Dworkin não apresenta uma explicação satisfatória para a relação ética e comunidade na Tanner Lecture, mas no seu texto "Comunidade Liberal” na VS ele estabelece que o sucesso da vida de cada indivíduo não está separado da comunidade.
} 
Para Dworkin, a melhor métrica para o valor de uma vida está baseada no modelo de desafio, no qual a vida de cada um de nós tem o seu valor no ato de viver, no enfrentamento das circunstâncias corretas. Estas significam que a vida terá menos valor caso os recursos não sejam distribuídos de forma igualitária segundo o parâmetro da justiça. Isso pode nos garantir uma boa vida e a neutralidade ética em relação a nossas convicções. O autor defende um liberalismo baseado na igualdade, por isso, alguns autores enfatizam que o nome de igualdade liberal é para dar força a esse argumento. Para Dall’Agnol (2005), Dworkin pretende defender o liberalismo de sua proteção excessiva dos interesses individuais em detrimento do bem-estar social. Mas, na realidade, quer mostrar justamente que a proteção dos direitos individuais não é incompatível com a defesa da igualdade e da comunidade. Podemos ter os direitos individuais garantidos numa concepção abrangente de liberalismo. Berkowitz (2000) define bem a proposta dworkiana em comparação à versão clássica do liberalismo:

\begin{abstract}
"Dworkin's liberalism is egalitarian, rights-based, procedural, and progressive. All American liberals affirm human equality, but Dworkin's liberalism declares it an imperative of justice that the state guarantee a substantial degree of social and economic equality through a generous welfare system, universal health care, and an agressive affirmative-action program. All liberals invoke individual rights, but Dworkin's greatest concern is with those that protect the freedoms of speech, sexual choice, and a dignified death. All liberals emphasize the rule of law and impartial administration of justice, but Dworkin's philosophy demands that government remain neutral toward competing conceptions of the good life, especially those grounded in traditional religious faith. And while it is an axiom for liberals that upholding the principles of freedom and equality promotes human progress. Dworkin's liberalism stands out for its resolute if unstated conviction that morality and law require a legislative agenda and a constitutional jurisprudence that, on virtually all important points, converge with the political program of the left wing of the Democratic party.” Berkowitz (2000:43).
\end{abstract}

Dworkin é um defensor mais radical da igualdade e da tolerância liberal, mas seu projeto até agora ainda não nos apresentou qual o lugar da comunidade e como esse liberalismo mais abrangente se apresenta diante das críticas dos comunitaristas, que afirmam que o liberalismo é excessivamente individualista e despreza a comunidade. Esse será o objeto da próxima seção. 


\subsection{O Lugar da Comunidade}

O capítulo 5 da VS é dedicado a nos apresentar o lugar da comunidade na igualdade liberal. Como o autor nos antecipa no prefácio do referido livro, o princípio de igual consideração e respeito está relacionado com dois princípios do individualismo ético: o da igual importância e da responsabilidade especial. Do primeiro não se deriva o "princípio da beneficiência" qual seja, de que as pessoas teriam obrigação moral de sempre agir com os outros da mesma forma que com seus entes queridos e com elas mesmas. Ele exige que as pessoas tenham igual consideração com um grupo de pessoas em determinadas circunstâncias. A comunidade deve ser imparcial com relação a seus governados e a igual consideração é a virtude do soberano.

O princípio da responsabilidade especial nos diz que somos responsáveis pelas nossas escolhas, pelos nossos projetos de vida e claramente não endossa nenhuma concepção de boa vida.

O papel da comunidade será o de garantir o pleno atendimento dos dois princípios, das leis e dispositivos que não dependam da origem, raça ou posição social, além de ser sensível às escolhas das pessoais. Quando expusermos os mecanismos de compensação que essa comunidade deverá utilizar, entenderemos como ela dará conta dessa exigência.

No igualitarismo liberal defendido por Dworkin a tolerância liberal não é incompatível com essa versão de liberalismo baseada na igualdade que, por sua vez, defende a continuidade entre ética e moralidade. Portanto, Dworkin apresenta uma proposta que ele chama de "uma terceira via" entre o liberalismo clássico e o comunitarismo.

Dworkin aborda a questão apresentando as principais objeções à tolerância liberal, chegando finalmente ao argumento da integração que ele considera mais interessante e promissor. Para ele, o liberal integrado não tem o mesmo comportamento do liberal 
não integrado. Este traça uma linha divisória nítida entre o que a justiça exige dele e o êxito crítico da sua vida, ou seja, não vai considerar que a sua vida é menos bemsucedida se a sua comunidade aceitar a desigualdade econômica, desde que ele mesmo não seja vítima.

"Essa fusão entre a moralidade política e o interesse próprio crítico me parece ser o verdadeiro ponto nevrálgico do republicanismo cívico, a maneira importante como os indivíduos devem fundir seus interesses e sua personalidade à comunidade política." (VS: 324).

Devemos então apresentar seu conceito de comunidade de tal forma que o liberalismo mais abrangente não seja incompatível com a comunidade, mas indispensável a ela.

Existem inúmeros argumentos para atacar a tolerância liberal e Dworkin vai tratar de apenas quatro. O primeiro relaciona a democracia com o direito da maioria, dizendo que a maioria teria o direito de impor uma determinada ética para todos os cidadãos. O segundo é um argumento com base no paternalismo, para o qual cada cidadão tem a responsabilidade pelo bem-estar dos outros membros da comunidade e deve empregar o poder político para “corrigir” comportamentos desviantes. O terceiro é o argumento chamado de interesse próprio, que condena o atomismo e a idéia de que os indivíduos são auto-suficientes. A comunidade é importante para a vida dos indivíduos. E, finalmente, o quarto argumento é o da integração, que alega que o valor da vida de cada indivíduo é reflexo ou função da vida da comunidade. Ele vai analisar cada argumento contra a tolerância liberal e mostrar como são interpretações equivocadas e, no caso do argumento da integração, mostrar que este argumento expressa, em parte o conceito de comunidade proposto pelo autor.

Dworkin é um liberal partidário da idéia de que as pessoas devem identificar seus interesses com os da comunidade política e que o liberalismo oferece a melhor interpretação do conceito de comunidade. Cada comunidade possui um ambiente ético que tem forte influência sobre as vidas dos indivíduos e disso não podermos escapar. 
O autor propõe que tratemos nosso ambiente ético da mesma forma que o ambiente econômico. Ele utiliza o primeiro argumento contra a tolerância liberal para defender essa questão. Quando a maioria é quem decide, o ambiente ético é do tipo "tudo ou nada”, que ele chama de majoritarismo substantivo. Significa dizer que, quando há controvérsias acerca do ambiente ético, não é justo que uma minoria dite a vontade para a maioria. $\mathrm{O}$ ambiente ético é decidido coletivamente. Mas numa outra esfera fundamental da vida, que é o ambiente econômico, essa forma "tudo ou nada” não é a mais adequada porque viola os preceitos de justiça e nem a democracia exige que decidamos desta forma em todas as esferas da vida. Segundo Dworkin, o ambiente econômico nos afeta de maneira mais clara que o ético, afinal estamos falando de distribuição de ativos.

"O ambiente econômico pode frustrar meus esforços de criar meus filhos com os valores que posso querer que tenham; não posso, por exemplo, educá-los para que tenham os conhecimentos e a experiência de colecionar as obras-primas do Renascimento.” (VS: 295).

A justiça requer que as parcelas distribuídas sejam justas, mesmo que tenhamos controvérsias em definir o que seriam essas parcelas. Mas para Dworkin, mesmo assim podemos dizer que qualquer teoria de justiça rejeitaria essa forma majoritária de decisão. Podemos rejeitar a idéia de que a decisão cabe sempre a uma maioria. Ele nos propõe, ao contrário, que o ambiente ético e o econômico sejam produtos de uma escolha pessoal e não de uma maioria que quer o tudo ou nada.

Evidentemente, ele não exclui que em determinadas situações as decisões não serão individuais, como a regulamentação do mercado para evitar o monopólio, por exemplo. Serão necessárias leis para proteger esse ambiente econômico e torná-lo o mais próximo de um ideal de justiça. O mesmo se exige para o ambiente ético, mas isso é totalmente diferente de impedir que uma minoria não tenha qualquer tipo de impacto no ambiente ético.

As decisões individuais nos dois ambientes estarão assentadas numa distribuição justa de recursos, proporcionando o impacto de cada um nesses ambientes igual ao das 
demais pessoas. Dworkin completa afirmando que se o ambiente econômico for tratado da mesma forma que o ambiente ético, ou seja, que seja formado por decisões individuais baseadas numa distribuição justa de recursos, não faz sentido falarmos de uma decisão por maioria. Cada um vai viver no ambiente que a justiça permite. Não há motivo para tratarmos o ambiente ético de modo diferente do ambiente econômico.

Essa forma de tratamento igual para os dois ambientes resgata sua idéia de integridade desenvolvida em ID. ${ }^{146}$ Para ele, não devemos tratar os dois ambientes com diferentes regimes de justiça porque não se trata de dois ambientes diferentes, mas aspectos interdependentes de um só ambiente. A integridade exige que algumas questões de princípio sejam decididas da mesma maneira para todos.

"Integridade exige que as normas públicas da comunidade sejam criadas e vistas, na medida do possível, de modo a expressar um sistema único e coerente de justiça e equidade na correta proporção.” (ID: 264).

No entanto, as razões que nos levam a decidir algumas questões coletivamente não podem ser usadas para decidirmos as questões do ambiente ético. Não faz sentido essa exigência. Como decidimos as questões nos dois ambientes de diversas maneiras, não estaremos ferindo a integridade.

Assumindo que os dois ambientes são unificados, é preciso considerar a tolerância liberal em questões de ética, caso contrário estaríamos negando essa unidade. Mas esse primeiro argumento rebatido pelo autor tem seus limites e serve apenas para negar que a maioria deve decidir questões no ambiente ético.

O segundo argumento contra a tolerância liberal é o do paternalismo, no qual temos uma comunidade cujos membros se preocupam verdadeiramente, com o bem-estar dos demais de forma desinteressada. Isso significa que a comunidade teria o mesmo

${ }^{146}$ Ver mais no capítulo 6 de ID. 
interesse pelo bem-estar crítico e pelo volitivo de seus membros. Relembrando o capítulo anterior, são tipos de interesse que todos temos e que podem melhorar ou piorar a nossa vida. O bem-estar crítico é quando alcançamos aquilo que devemos desejar, aquilo que tornaria nossa vida criticamente melhor. Já o bem-estar volitivo é quando alcançamos o que queremos. Nesse aspecto, Dworkin alerta para o fato que podemos ter julgamentos errados acerca dos interesses críticos, do que é realmente importante na vida; no entanto, ele afirma que isso não significa que os interesses volitivos não sejam genuínos. Ao contrário, são genuínos e não apenas reflexos do que queremos hoje. Podemos querer algo que não necessariamente vai melhorar a nossa vida. Ter apenas interesses críticos tornaria a nossa vida "triste e ridícula"147. Vamos considerar os dois tipos de interesses para definir dois tipos de paternalismo.

O paternalismo crítico afirma que a coação pode oferecer uma vida melhor do que a que os indivíduos pensam ser boa e, por isso, ela estaria entre seus interesses críticos. O paternalismo volitivo afirma que a coação oferece uma vida que as pessoas querem alcançar e estaria, também, entre seus interesses volitivos. O segundo argumento contra a tolerância liberal se apóia no primeiro tipo de paternalismo.

Dworkin aceita a tese de que o valor crítico de uma vida é do tipo constitutivo, ou seja, dependerá do endosso de cada um, sem ele não há valor algum. Assim, o paternalismo crítico não melhora a vida de quem não endossa ${ }^{148}$ suas restrições. O segundo argumento, assim, não se sustenta.

O terceiro argumento analisado pelo autor é a idéia de que as pessoas necessitam da comunidade e que a vida social é um elemento fundamental para os indivíduos. Podemos dizer que a comunidade tem algumas vantagens fundamentais: ela dá segurança e um ambiente econômico organizado para as atividades de produção e consumo. Além disso, Dworkin acrescenta as necessidades intelectuais e as de

\footnotetext{
${ }^{147}$ VS: 300 , nota 12.

148 Aqui Dworkin considera formas legítimas de endosso, caso contrário uma lavagem cerebral tornaria o paternalismo aceitável.
} 
objetividade. As necessidades intelectuais estão ligadas, principalmente, à cultura e à língua, ambos fenômenos sociais. Mas disso não decorre que precisamos de uma homogeneidade moral, ao contrário, sociedades mais tolerantes podem ser muito mais ricas culturalmente.

Dworkin afirma que Sandel (1998) ${ }^{149}$ apresenta mais uma razão para não prescindirmos da comunidade, que é a nossa busca pela identidade e auto-referência. Como saber se somos brasileiros e nos identificar como tais? Ou como ser católico sem estar conectado ao seu grupo ou igreja? Mas o argumento não é suficiente para apoiarmos a tese de que a tolerância destrói a comunidade. A tolerância não abala as nossas convicções, mas permite que cultivemos algumas que não são necessariamente as mais populares. Não há razão para imaginar que por isso a nossa personalidade se desintegraria.

As necessidades de objetividade dizem respeito ao argumento de que as pessoas precisariam da comunidade moralmente homogênea como fundamento para sua vida moral e ética, como se fosse uma âncora. Âncora, isto é, como se fosse um apoio externo para as convicções pessoais, ou seja, apoio representado pelas convicções comuns não questionadas da comunidade. Quase uma justificação arquimediana. Para Dworkin faz sentido o apoio, mas a comunidade não é o único apoio disponível.

O quarto e último argumento é para o autor mais atraente, o da integração. Este argumento é contra a idéia de que há uma diferença entre o bem-estar do indivíduo e o bem-estar da comunidade a qual pertence. Dworkin denomina aqueles que referendam essa idéia de republicanos cívicos.

“Eles (os republicanos cívicos) adotam, com relação à saúde moral e ética das comunidades, a mesma atitude que adotam com relação a si mesmos. Os liberais entendem a questão de se a lei deve tolerar ou

\footnotetext{
149 Sandel (1998) faz uma crítica ao liberalismo na versão apresentada por Rawls. Sua crítica é a prioridade da justiça derivada da prioridade do direito sobre o bem de Kant. No capítulo final analisaremos a crítica de Sandel que corrobora para a versão de liberalismo abrangente de Dworkin.
} 
não o homossexualismo como uma pergunta sobre se as pessoas têm o direito de impor às outras suas próprias convicções éticas. Os republicanos cívicos compreendem-na como uma pergunta sobre se a vida normal da comunidade, da qual depende o valor essencial da vida de seus próprios membros, deve ser saudável ou degenerada." (VS: 309-10).

Para Dworkin, o problema não está em considerar que a comunidade é importante para o êxito ou fracasso de nossa vida, mas em não compreender o caráter que a vida comunitária de uma comunidade política pode ter. A nossa vida não é a da comunidade, ou seja, a vida comunitária não tem todas as nossas nuances e angústias, não tem os afetos, a vida sexual, etc. A vida da comunidade não é a soma das vidas de todos os seus membros. Porém, a premissa de que a comunidade tem um papel importante nas nossas vidas permanece, e será preciso oferecer um conceito menos antiliberal para a vida comunitária. Para isso, o autor vai trabalhar com conceitos de agência para definir melhor a idéia de integração.

O cidadão integrado tem interesse na sua própria vida e, devido a isso, se volta para a comunidade. Isso é bem diferente de afirmar que as pessoas se interessam apenas altruisticamente pelo bem-estar dos demais membros de sua comunidade.

As diferenças entre o paternalismo, o altruísmo e a integração podem ser mais bem entendidas se usarmos os conceitos de unidade de agência e de unidade de preocupação. Quando eu tomo alguma decisão ou ação, eu serei a unidade de agência das ações, quando faço algo para meu próprio bem-estar, a unidade de agencia e a unidade de preocupação são as mesmas. Porém, o altruísta tem como unidade de preocupação da agência algo mais do que ele próprio. O paternalismo, segundo Dworkin, é um caso de altruísmo.

A integração considera que a unidade apropriada da agência, para ações que afetem o bem-estar do indivíduo, é a comunidade e não o indivíduo. 
"Ele [membro da comunidade] pertence eticamente a essa unidade da agência [a comunidade]: participa do êxito ou do fracasso de atos, dependentes de qualquer coisa que ele mesmo, considerado como indivíduo, tenha feito.” (VS: 312).

Um exemplo usado por Dworkin é emprestado de Rawls, que é a orquestra. Uma orquestra é uma unidade de agência, e seu êxito ou fracasso os são também de seus músicos. Na integração, a comunidade é a unidade de agência e não há uma explicação privada de êxito ou fracasso. O paternalismo e o altruísmo são exemplos de unidade de agência individuais, em vez de coletivos.

Mas podemos ter duas interpretações da integração, uma que considera a comunidade como uma estrutura metafísica, acima dos indivíduos, a perspectiva metafísica, e outra que estaria ligada às práticas sociais, a perspectiva prática. Ou seja, os indivíduos compreendem, nesse caso, que são componentes dessa unidade de agência. No entanto, novamente é importante destacar, a comunidade não é uma somatória dos êxitos e fracassos individuais, ao contrário, tem interesses e preocupações próprios.

Dworkin quer mostrar que as práticas sociais efetivamente criam uma unidade de agência, ou seja, precisamos de alguma teoria que determine como elas se formam e como participamos delas. A vida comunitária de uma comunidade é constituída de atos coletivos que o são devido às práticas por ela (a comunidade) criadas.

Esses atos coletivos têm como características: devem ser identificados como atos de toda a comunidade e não dos membros; os atos individuais que constituem os atos coletivos são combinados, ou seja, são realizados em prol do coletivo, por exemplo, a execução da orquestra não é apenas uma somatória de músicos, estes executam a música de acordo com um ritmo compartilhado e, por último, os membros da comunidade se adaptam aos atos da comunidade, ou seja, dado que a orquestra é uma unidade comum da agência para a produção de música, os seus componentes são, portanto, músicos. 
A orquestra como exemplo é útil para evidenciar os limites da vida comunitária. Para os músicos, a vida musical, não envolve, por exemplo, a vida sexual de quem participa da orquestra. A frase de Dworkin é instrutiva: "Sua integridade (da orquestra) moral não é prejudicada pelo adultério do percussionista.” (VS: 316).

Considerando a perspectiva prática do conceito de comunidade, quais atos então fazem parte da vida comunitária? Dworkin argumenta que além dos atos formais como as decisões do legislativo, judiciário, executivo, nossa participação por meio do voto, manifestações públicas, poderia pensar que a comunidade tem mais do que isso. Se assumirmos a interpretação metafísica, ela nos diz que a comunidade tem, inclusive, uma vida sexual. No entanto, destaca o autor, as nossas convenções não reconhecem essa “atividade sexual coletiva”. Além disso, a definição da comunidade política não requer tal pressuposto.

\begin{abstract}
"Podem nascer pessoas de todas as raças, credos e aspirações dentro da mesma comunidade política, e é bem implausível que a caracterização de vida comunitária que melhor se encaixe em tal comunidade seja a que presume que se deve escolher um credo, um conjunto de aspirações pessoais ou afiliação étnica, ou um conjunto de padrões de responsabilidade sexual, como deve uma pessoa individual sadia. Essa caracterização, além de não se encaixar nos critérios de cidadania, torna-os quase sem sentido.” (VS: 319).
\end{abstract}

Obviamente, isso não significa que as pessoas não pertençam a grupos, comunidades que tenham algum tipo de comportamento sexual compartilhado, mas é diferente de se afirmar que uma comunidade tem uma vida sexual. Esse é um argumento antiliberal da integração que não é defendido por Dworkin. O argumento pela integração toma outra direção.

Para Dworkin, há uma premissa correta no argumento da integração, qual seja, de que a integração política tem importância ética e não é incompatível com os princípios liberais. A vida comunitária tem importância para a vida de seus membros, mas isso não significa que há uma homogeneidade entre a minha vida e a da comunidade, vista então, erroneamente, como uma super-pessoa. O argumento de Dworkin é que os 
indivíduos se identificam com a comunidade quando reconhecem que ela tem uma vida comunitária, e que o êxito e o fracasso de sua vida pessoal dependem eticamente do êxito e fracasso da vida da comunidade ${ }^{150}$.

Para que tenhamos uma interpretação da vida comunitária que não ameace os princípios liberais, parece sensato dizer que a versão utilizada deve ser menos abrangente, ou com limitações. O conceito segue:

\begin{abstract}
“É um conceito completo, genuíno, intenso, exatamente porque é discriminador. Os que argumentam que a identificação com a comunidade requer leis iliberais não defendem um nível mais profundo de identificação do que o permitido pelo liberalismo. Defendem apenas uma visão diferente do que a vida coletiva da comunidade realmente é. Se a tese liberal estiver correta, e a deles equivocada, o liberalismo proporciona uma forma mais genuína de identificação do que seus críticos conseguem oferecer.” (VS: 322).
\end{abstract}

Portanto, o autor quer nos apresentar sua interpretação da comunidade liberal. A vida comunitária da comunidade liberal está limitada ao campo político ${ }^{151}$, ou seja, aos atos políticos formais. Assim, os membros da comunidade se sentirão integrados com esses atos, e sentirão seus efeitos sobre suas vidas. À primeira vista pode ser uma definição decepcionante, mas para Dworkin o conceito defendido não amplia o que os liberais já aceitam, apenas reforça que a tolerância é importante para o êxito das decisões políticas. Portanto, a integração não representa uma ameaça aos princípios liberais.

"Se a vida da comunidade circunscreve-se a decisões políticas
formais, se o êxito crítico da comunidade, por conseguinte, só
depende do êxito ou do fracasso de suas decisões legislativas,
executivas e adjucativas, então podemos aceitar a primazia ética da
vida da comunidade sem abandonar ou comprometer a tolerância
liberal e a neutralidade acerca da vida boa. Simplesmente repetimos
que o êxito nas decisões políticas requer a tolerância.” (VS:323).

\footnotetext{
${ }^{150}$ VS: 321-22.

${ }^{151}$ Questão interessante para discutirmos com o Liberalismo Político de Rawls, que também limita a comunidade ao campo político.
} 
O que há de novo? Para Dworkin, o novo é que o cidadão integrado faz uma fusão entre a moralidade e o interesse próprio já que não separa o seu bem-estar do da comunidade. Sua vida será afetada por uma sociedade injusta e que permite desigualdade de renda e preconceito. Mais do que isso, o cidadão integrado acredita que as pessoas devem ser tratadas com igual consideração e respeito.

Essa integração defendida por Dworkin revela o interesse comum, sem comprometer os princípios liberais. O interesse comum é o da justiça para si, porque está nos seus interesses críticos, e para os demais. Isso dá o que ele chama de estabilidade e legitimidade diante da pluralidade das concepções da boa vida. Ainda, ninguém se achará fazendo sacrifício para um bem comum quando se almeja a justiça. Dworkin não diz textualmente, mas é claro que exclui teorias de justiça com a métrica do bemestar.

O que garante que as pessoas aceitem essa forma integrada? Dworkin não nos dá uma resposta definitiva, como ele mesmo repara, mas aqui ele traz o que discutimos no capítulo anterior, qual seja, a tese platônica de que se não vivemos com o quinhão justo de recursos, o valor ético da nossa vida está comprometido. Quando falamos no princípio abstrato de igual consideração e respeito, nos deparamos com um dilema ético: o primeiro ideal ético domina a nossa vida pessoal na qual não tratamos as pessoas da mesma maneira que nossos filhos e parentes. O segundo ideal está na nossa vida política, na qual um cidadão justo trata os demais com igual consideração. $\mathrm{O}$ desafio é a integração ética desses dois mundos, e a forma de se fazer isso é a política conseguir distribuir os recursos da forma exigida pela justiça, caso contrário, sociedades desiguais serão prisioneiras do dilema ético, e considerarão que devem fazer uma escolha trágica entre os dois ideais éticos. O autor, pelo contrário, reforça que uma sociedade justa é pré-requisito para a conciliação de ambos os ideais, daí a primazia ética da comunidade nas nossas vidas. 


\section{Capítulo 3 \\ A Teoria de Justiça de Dworkin: A Igualdade de Recursos}

Depois de apresentarmos como os dois modelos propostos por Dworkin respondem ou tentam responder a algumas questões da filosofia política, o autor afirma que ainda não definimos o que tem valor ou que tipo de desafio é valioso ${ }^{152}$.

Aqueles que adotam o modelo de desafio e que consideram seus interesses críticos, são chamados de "liberais éticos" e escolheriam uma concepção de liberalismo denominada "igualdade liberal". Segundo ele, a igualdade liberal seria a mais adequada para nos confirmar que o liberalismo se une com a ética no modelo do desafio.

Os liberais éticos têm todas as informações necessárias, seus interesses e convicções, situação diferente das partes na posição original de Rawls. Estes têm como função determinar os princípios de justiça considerando que podem estar pior posicionados, enquanto que para Dworkin a divisão dos recursos é feita considerando um critério de justiça na qual todos compartilham: as pessoas devem ser tratadas com igual consideração e respeito.

Os liberais éticos escolherão a teoria correta da justiça porque somente essa terá valor para a sua vida, e isso não é um problema, já que é de interesse de cada um que a justiça prevaleça. Aqui a ética se conecta com a política, portanto, à comunidade liberal.

"I mean only that the challenge view supports equality of resources directly, as flowing from people's sense of their own best interests critically understood. When we have reached that point, the argument becomes reciprocal, for the fact that equality is a natural theory of justice on the challenge model in turn supports the idea with which we

\footnotetext{
${ }^{152}$ Mesma questão tratada em Clayton (2002).
} 
begin, that justice is a parameter of ethics. Living well has a social dimension, and I live less well if I live in community with others who treat my efforts to lead a good life as unimportant." (FLE: 290).

Os liberais éticos e seu modelo do desafio nos mostram que cada indivíduo definirá seu plano de boa vida. Os recursos serão os meios para que as pessoas possam enfrentar o desafio de viver. Visto que a boa vida é aquela que é justa e entendemos a justiça, como distribuição igualitária de recursos, temos que os liberais tomam a justiça como parâmetro.

Outro ponto fundamental é que a tolerância é uma característica da igualdade liberal, visto que o Estado não determina o que é a boa vida, mas participa da definição das circunstâncias sob as quais vamos poder seguir nossos planos de vida. A igualdade liberal ou a versão do liberalismo de Dworkin quer nos igualar nas circunstâncias e nos recursos e, se aceitamos isso, devemos aceitar a tolerância liberal. A liberdade, a igualdade e a comunidade não estão em conflito.

Como vimos no capítulo sobre o método de Dworkin, estamos tratando de uma teoria moral com forte ligação com a teoria do direito. A igualdade é central na filosofia política de Dworkin assim como na filosofia do direito.

"The connection with law is that making the best sense of the law means making the best moral sense of it and that means making the best sense of it in terms of equality." Guest (1997:209).

Sem determinar o que é a igualdade, não há como determinar nossos direitos e deveres. Assumindo o conceito abstrato de que todos devem ser tratados como iguais, precisamos então mostrar como alcançar esse ideal. A partir daí é possível definir o aparato legal para a vida em comunidade. 
A seguir, vamos apresentar a forma como os recursos são distribuídos, o leilão, o seguro hipotético, por que a igualdade liberal é uma teoria sensível às ambições dos indivíduos e qual o lugar da liberdade na igualdade de recursos.

\subsection{A Igualdade de Bem-estar versus Igualdade de Recursos}

Segundo Dworkin, a igualdade absoluta é um valor político fraco e facilmente derrotado. Mas, como filósofo político, é justamente a igualdade a maior das suas preocupações. A partir do conceito de igualdade é que determinaremos nossos direitos e deveres, por isso a filosofia política de Dworkin está firmemente conectada a sua filosofia do direito. ${ }^{153}$

Para Clayton \&Williams (2009), há uma divisão na filosofia anglo-americana entre dois tipos de princípios de justiça distributiva: os princípios estritamente igualitários e os prioritários. O primeiro grupo afirma que não é justo que alguns estejam em pior situação que outros. Já o último grupo favorece os piores posicionados. Podemos dizer que os estritamente igualitários estão preocupados com a desigualdade e os prioritários, com as necessidades mais urgentes. Ambos precisam de um padrão de comparação interpessoal, ou como diria Cohen (1999), “a currency of egalitarian justice”. A igualdade de recursos, proposta por Dworkin, é uma das teorias preocupadas com a desigualdade.

Dworkin decide contrapor dois tipos de igualdade a fim de definir qual seria a melhor métrica de justiça, exatamente para que tenha força política suficiente para ser alcançada ${ }^{154}$.

\footnotetext{
${ }^{153}$ Guest (1997:209).

${ }^{154} \mathrm{O}$ próprio autor afirma que essa escolha não esgotaria outros tipos de igualdade, nem mesmo uma combinação entre elas, mas para ele seria suficiente afirmar que a igualdade de bem-estar não é a melhor métrica se comparada à igualdade de recursos.
} 
Ele começa com o conceito de bem-estar, que foi criado para atribuir valor aos recursos, estes têm valor se gerarem bem-estar. Quando usamos o bem-estar como medida de igualdade, temos algumas conseqüências importantes. Pessoas com necessidades especiais (deficiências físicas ou mentais) demandarão mais bens para alcançarem o mesmo nível de bem-estar dos demais, assim como o caso de pessoas de gostos dispendiosos e extravagantes. Para Dworkin isso não está correto, e vai mostrar que a igualdade de bem-estar não deve ser considerada como métrica da igualdade porque nos leva a resultados contra-intuitivos e injustos.

Temos diferentes tipos de teoria de bem-estar, principalmente, as de êxito e as de estado de consciência ${ }^{155}$. O primeiro grupo presume que o bem-estar individual depende do êxito na satisfação de preferências, metas ou aspirações. Neste caso, a transferência de recursos deve ocorrer até que nenhuma parcela adicional reduza as diferenças de êxito da vida das pessoas.

As pessoas possuem preferências distintas, desta forma teremos inúmeras versões de igualdade de êxito. Temos as preferências políticas, que têm a ver com a forma como achamos que a distribuição de bens e oportunidades deve ser realizada na comunidade. As preferências impessoais, por outro lado, são aquelas que tratam de preferências em relação a coisas que não nos pertencem ou à vida de outras pessoas. Por exemplo, preferência por descobertas científicas que curem doenças como o câncer, ou ainda, que o presidente dos Estados Unidos tenha sucesso em acabar com a guerra no Iraque. Por último, temos as preferências pessoais, que se relacionam com o que queremos para as nossas vidas. Um adolescente que quer passar no vestibular ou nosso plano de construir uma família, por exemplo.

\footnotetext{
${ }^{155}$ Existiria uma terceira classe, que são as teorias objetivas, mas que Dworkin não irá analisar tão profundamente. Importante destacar que ele não espera esgotar todas as teorias de bem-estar com esses três grupos, mas enumerar as mais influentes e analisar se elas são uma alternativa para o conceito de igualdade que está buscando.
} 
O segundo tipo, as teorias de estado de consciência, afirma que a distribuição deve tentar deixar as pessoas num nível máximo de igualdade em algum aspecto de sua vida. Jeremy Bentham afirmava que o bem-estar é um balanço entre o prazer e a dor, e, claro, quanto maior o prazer e menor a dor, maior será o seu bem-estar.

"Bentham achava que todo ato e toda a decisão humanos eram motivados por alguma estimativa de prazer e de dor e acreditava que toda decisão política deveria ser tomada com base nessa mesma estimativa, isto é, maximizando o resultado líquido tão somente do prazer e da dor para a comunidade como um todo.” (LDS: 402).

Mas Dworkin ${ }^{156}$ prefere utilizar os conceitos de satisfação e insatisfação para designar os diferentes estados de consciência, pensando num conceito mais amplo do que o conceito benthamita de dor e prazer. Seu objetivo é que eles possam identificar nossos desejos e que sejam passíveis de identificação. Assim como nas teorias de êxito, temos diferentes preferências (políticas, pessoais e impessoais) e teremos, portanto, versões que podem incluir uma ou mais preferências.

Primeiro vamos analisar se as diversas versões das teorias do êxito são um tipo de métrica de igualdade a ser alcançada. Consideramos a versão mais irrestrita das preferências políticas. Essa versão de igualdade somente faria sentido se as pessoas de uma comunidade compartilhassem as mesmas preferências políticas, já que sempre haverá alguém que discordará de alguma teoria política formal ou informal. Ou ainda, podemos ter casos em que há concordância com relação à teoria política, como o caso de castas na Índia. Mesmo que tenha o apoio geral, não significa que seja justo. Devemos rejeitar teorias políticas não igualitárias.

Essa versão mais ampla da igualdade de êxito somente é possível quando as preferências políticas, nas palavras de Dworkin, são bem fundadas, e não apenas populares. Bem fundadas no sentido de que alguma teoria política formal já seria endossada numa versão mais restrita de igualdade de êxito.

\footnotetext{
${ }^{156}$ Segundo o autor, a dor, por exemplo, não captaria situações como o tédio e a depressão.
} 
A versão das preferências impessoais parece ainda mais complicada. Como o governo pode garantir que todas as nossas preferências, assim como a de todos, sejam atendidas igualmente? Será preciso definir quais preferências impessoais são razoáveis ou não, se, entre as minhas preferências seja acabar com a fome no mundo, com a corrupção no Brasil etc. São situações complicadas de igualar por essa métrica.

Segundo Dworkin, faz sentido dizer que devemos ter uma versão mais restrita ainda de igualdade de êxito, pessoal, mas que tenha elementos das outras duas num sentido distinto. A idéia é igualar as pessoas do ponto de vista pessoal, sem igualar no grau de aceitação que a sociedade terá e nossas convicções políticas, como era na versão das preferências políticas, nem igualar no grau de realização das visões que temos do mundo, como no caso das preferências impessoais.

As teorias de êxito baseadas nas preferências pessoais buscam igualar as pessoas no grau de realização das preferências das pessoas, e a distribuição de recursos deve obedecer a esta demanda.

As pessoas decidem o que fazer de suas vidas vislumbrando quanto de recursos terão disponíveis. Sem essa informação, elas não poderão elaborar seus planos de vida, algo que esse conceito de igualdade de êxito espera que as pessoas já tenham formulado. Ainda, devemos considerar que o valor que damos ao êxito e ao fracasso pessoais pode variar entre os indivíduos. As escolhas dos indivíduos são afetadas pelo hábito, sorte e oportunidade. Assim, os indivíduos definem suas preferências e, a partir daí, é possível perguntar se eles tiveram êxito em relação ao que planejaram para suas vidas. A este êxito Dworkin denomina êxito relativo.

“As preferências representam o resultado de uma decisão, de um processo de realizar o que a pessoa quer de mais concreto." (VS: 29).

Dworkin define o juízo do êxito total de uma vida como o valor que alguém atribui à sua vida. São as nossas conviç̧ões sobre o que dá sentido à vida, sem necessariamente 
uma articulação perfeita, mas de alguma forma, todos seríamos capazes de pensar sobre a questão.

A questão da divisão entre êxito relativo e total é que podemos dar pesos diferentes a eles. O exemplo dado é a escolha de uma pessoa entre ser um artista e ser um advogado, com a probabilidade grande de ser um brilhante jurista ou de um artista mediano. Alguém pode preferir ser advogado, dando um peso maior ao êxito relativo, mas outra pessoa pode querer ser artista pensando que a arte é mais importante que advogar. Aqui está a atração pela igualdade de bem-estar, já que o que realmente importa é o bem-estar e não bens. Estes atuariam como meio para se alcançar o bemestar. A definição que temos de igualdade de bem-estar é que "equipara as pessoas no que todas valorizam do mesmo modo e fundamentalmente, contanto que envolvam suas próprias situações e circunstâncias pessoais”. ${ }^{157}$ Diante disso, temos que os recursos poderão ser distribuídos de forma desigual para atender as preferências pessoais distintas. Para aqueles que não gostam de desafio ou buscam uma vida frugal, certamente receberão menos recursos ou bens que um jovem desbravador e que quer enriquecer no competitivo mercado financeiro.

As teorias de bem-estar continuam sendo atraentes porque igualam as pessoas no que realmente é importante, seu bem-estar, e os recursos ou bens são apenas os instrumentos para alcançá-lo. Adicionalmente, são teorias que dão tratamento diferenciado às pessoas com deficiências, exigindo que estas tenham mais recursos. Por isso, a teoria é atraente e dificulta a tarefa de apresentar uma alternativa, no entanto padece da sua imprecisão, já que não temos uma métrica que nos sirva de referência para distribuir os recursos. Não existe um teto máximo ou mínimo, apenas a "sensação" revelada de cada indivíduo. Na teoria de igualdade de êxito total, temos que perguntar como distribuir, dados juízos de valor distintos sobre o que fazemos da nossa vida. A resposta de Dworkin é que as pessoas podem "lamentar-se razoavelmente” em relação a situações normais da vida. Então, por exemplo, eu não 
poderia exigir mais recursos e me lamentar porque eu não tenho a capacidade de voar, mas posso lamentar razoavelmente se não consegui passar no vestibular de direito.

Assim, nossas solicitações de novos recursos estariam baseadas no grau de lamento razoável. Mas continuamos com um problema, como definir o que é razoável? Precisamos que a definição da teoria da igualdade de êxito total nos diga o que seria uma distribuição justa e, para evitar a circularidade do argumento, não podemos usar a lástima para definir o que é justo.

"A métrica da lástima razoável para decidir o êxito total faz assunções sobre qual é a distribuição justa, a qual distribuição as pessoas têm direito.” (VS:44).

Ainda é preciso encontrar uma métrica para a distribuição de recursos. Mas ela estará inserida na teoria de bem-estar?

Para o segundo tipo de teoria de igualdade de estado de consciência, encontramos as mesmas dificuldades para suas versões irrestritas de preferências políticas e impessoais. A satisfação, como já apontamos, é definida de forma mais ampla que sentimentos de prazer e dor. A igualdade de satisfação, portanto, busca uma distribuição de recursos de tal sorte que as pessoas sejam igualadas na satisfação de preferências pessoais. Mas assim como no bem-estar, os pesos dados para cada estado de consciência variam de pessoa para pessoa. Continuamos com os mesmos constrangimentos anteriores.

Uma alternativa às duas versões subjetivas, chamadas assim justamente porque não têm uma métrica, seria uma versão objetiva da igualdade do êxito total. Igualar as pessoas na quantidade de lástima que deveriam ter em relação a sua vida atual, sendo que ela presume uma teoria independente da distribuição.

Dworkin rejeita qualquer versão de igualdade de bem-estar como teoria de igualdade distributiva, porque ela ainda pode ser usada para a redistribuição de recursos para 
pessoas com gostos dispendiosos, cultivados ou não. Esse é um constrangimento que não é possível evitar se levamos adiante o projeto de teoria de bem-estar como nossa teoria de igualdade. É o argumento que Dworkin utiliza para mostrar que não é a nossa solução. Aqueles que têm gostos mais caros não podem ser considerados imorais. Não é isso. Apenas que, sob a teoria do bem-estar, outras pessoas serão afetadas negativamente pelos gostos de outrem. Ele usa como exemplo Louis, que tem gostos dispendiosos, como o consumo de champanhe. A igualdade de bem-estar recomendaria uma maior quantidade de recursos para ele. Esse é um resultado ineficaz, porque reduz o bem-estar total da sociedade, uma vez que o princípio utilitarista nos diz que a média do bem-estar deve ser a maior possível. Mas o princípio utilitarista apenas nos diz que é ineficaz, e não porque o ideal de igualdade não recomendaria essa redistribuição. Para Dworkin, as pessoas devem ser livres para viver a melhor vida possível com seu quinhão justo dos recursos sociais, mas não deve ser livre para invadir o quinhão justo dos outros, pois seria injusto com eles.

Portanto, a definição da teoria independente de parcelas justas não pode estar inserida na teoria de bem-estar, pois é a esta que se recorre para a redistribuição de gostos dispendiosos. Em outras palavras, parcelas justas não podem significar parcelas que geram bem-estar.

A alternativa que Dworkin nos apresenta como uma teoria de igualdade é a "igualdade de recursos”. Para uma sociedade justa devemos buscar a igualdade de recursos, sendo recursos tudo que os indivíduos possuam privadamente e que possam ser trocados ou transferidos. Os recursos podem ser pessoais ou impessoais, os primeiros seriam nosso talento, características físicas, mentais e emocionais e que, portanto, não podem ser transferidos ou comercializados. Os recursos impessoais seriam os nossos bens, ativos em geral. Mais especificamente, a igualdade de recursos vai buscar igualar os recursos impessoais, e compensar, por meio do mecanismo do seguro hipotético, as diferenças nos recursos pessoais. Não se inclui nessa hipótese, a divisão de poder político, que envolveria também os recursos públicos cuja posse permite aumento de riqueza e ainda mais poder. 
A igualdade de recursos deverá resolver alguns dos constrangimentos da igualdade de bem-estar, bem como ser tão atraente quanto. Dworkin vai tratar de forma especial os casos de deficiências e de talentos (ou a falta dele), situações que poderão ser compensadas ou não dependendo das escolhas de cada um. Ele está buscando as regras de redistribuição de recursos que obedeçam a algum princípio de justiça.

Para o autor, a distribuição igualitária de recursos pressupõe alguma forma de mercado como ferramenta analítica e como instituição política. O mercado é louvado pela sua capacidade de gerar prosperidade, eficiência e como condição necessária para a liberdade individual. Cada um de nós poderá ir ao mercado tentar realizar suas vontades e projetos, e será o mecanismo usado por ele para distribuir os recursos.

Mas o mercado também é visto como fonte das desigualdades. Dworkin não ignora as falhas de mercado, bem como não aceita a idéia de que eficiência é a justiça ${ }^{158}$. A diferença está que o mercado exacerba diferenças que existem entre os indivíduos quando as circunstâncias são distintas. Essas diferenças que os indivíduos não têm controle, ou que não foram escolhidas, serão compensadas pela igualdade de recursos. O mercado, assim como a posição original de Rawls, têm a mesma função, definir qual o quinhão justo a que cada um terá direito, mas adicionalmente, a posição original define quem será compensado pelo princípio de diferença. Veremos que a compensação para Dworkin não depende da posição na pirâmide social, mas de ter sido ou não produto de escolha ou circunstância. Segundo Dworkin, o mercado deverá estar no "núcleo de qualquer elaboração teórica atraente de igualdade de recursos”.

"Isto é, defende-se o mercado tanto por argumentos de prudência política, que enfatizam os ganhos gerais que esse mecanismo produz

\footnotetext{
${ }^{158}$ Dworkin não é um defensor dos princípios da economia neoclássica de que o mercado é autoregulado, informação completa, sem custos de transação e perfeito. Ao contrário, é um forte crítico da Escola de Chicago de economia e direito, berço dos economistas neoclássicos, e que assume a idéia de uma justiça baseada no critério de maximização da riqueza. Um dos seus mais importantes adversários é Posner, que usa aquele critério como medida de como um juiz deve julgar um caso. "This criterion states that a decision, or policy, is wealth- maximizing if the amount of wealth created by the decision is enough to compensate those who are left with less wealth after the decision. Importantly, there is no requirement that those who lose wealth in the process should be compensated. It is just cost/benefit analysis.” Guest (1997: 191).
} 
para toda a comunidade, e por argumentos de princípio, que apelam, pelo contrário, para um suposto direito à liberdade.” (VS:80).

Rawls em TJ também louva a capacidade alocativa do mercado perfeito sem ignorar suas imperfeições. Ele acrescenta que o mercado "descentraliza o exercício do poder econômico"159 e aplica seu mecanismo também considerando uma economia socialista, com o cuidado para diferenciar as funções alocativas e distributivas. Portanto, na teoria de justiça rawlsiana, o uso do mercado é independente do regime político. Isso nos ajuda a ver o mercado como instrumento de definição de preços. Mas, para Dworkin, devemos rejeitar qualquer forma de distorção dos preços via controle estatal, visto que um mercado livre ${ }^{160}$ é indispensável para a igualdade. Aplicado à TJ, o mercado “é compatível com as liberdades iguais e com a igualdade equitativa de oportunidades. Os cidadãos têm liberdade de escolha de carreiras e ocupações. Não há motivo nenhum para haver um controle centralizado e coercitivo da força de trabalho.”161

Então, como o mercado poderá nos ajudar na distribuição igualitária de recursos?

Dworkin vai utilizar a metáfora dos imigrantes numa ilha deserta com recursos abundantes, na qual ninguém tem a posse prévia de nada na ilha visto, que todos chegaram nas mesmas condições. Esses imigrantes decidem que precisam distribuir os recursos igualmente e criam um teste para se saber se a divisão é mesmo igualitária, o teste de inveja. Se a divisão for igualitária ninguém invejará/desejará a cesta de recursos de outra pessoa. Como já ressaltamos o termo inveja não é usado no seu sentido psicológico, mas econômico. Este teste tem a mesma função da "lástima razoável” que vimos anteriormente, quando discutimos a igualdade de bem-estar.

\footnotetext{
${ }^{159}$ Rawls (2008: 339).

${ }^{160}$ Ele não descarta a regulação para evitar distorções como monopólios e externalidades. Mas uma economia igualitária é uma economia de mercado. Dworkin (2009:243).

${ }^{161}$ Rawls (2008:339). Na TJ, o autor se vale de um regime de cidadãos-proprietários. Ver mais no capítulo 5 da TJ.
} 
Assume-se que seja possível dividir os recursos em porções que atendam aos desejos dos imigrantes.

Existem dois tipos de recursos, os pessoais, nossas características físicas, mentais e emocionais que não podem ser trocadas ou transferidas, e os impessoais, que são os bens em geral e que, portanto, podem ser trocados. Os imigrantes dividirão os recursos impessoais em porções igualitárias.

Qual o método que esses imigrantes poderiam utilizar para chegarem a uma distribuição igualitária? Podem utilizar o método de tentativa e erro para a distribuição igualitária das porções, mas poderá não ser útil e será preciso algum tipo de coordenação já que poderemos ter situações em que o responsável pela divisão transforme os recursos em cocos e bananas. Isso seria arbitrário e injusto com quem não gosta desses alimentos. O teste de inveja poderá funcionar nessa situação, ou seja, não invejarmos a cesta de cocos e bananas de ninguém, mas muitos prefeririam que os recursos fossem tratados de outra forma e não trocados por cocos e bananas. Para evitarmos essas arbitrariedades e sistematizar as trocas, o responsável pela divisão precisa de um mecanismo de mercado, o sugerido por Dworkin é o leilão ${ }^{162}$.

Cada imigrante terá em mãos a mesma quantidade de uma "moeda”, no caso conchas, para fazer seus lances. Cada lote do leilão terá um preço determinado pelo leiloeiro ${ }^{163}$. Esse conjunto de preços atende a todos os mercados, ou seja, haverá apenas um comprador por cada preço e todos os lotes serão vendidos.

\footnotetext{
${ }^{162}$ O tipo de leilão é o walrasiano. O nome vem do economista Leon Walras (1834-1910) que criou um sistema de equações para a determinação dos preços de uma economia concebendo a "teoria de equilíbrio geral”. O leilão walrasiano é uma ferramenta analítica para investigar estabilidade e equilíbrio. Os preços são fixos e os agentes registram o quanto de cada bem eles gostariam de oferecer (oferta) ou comprar (demanda). Nenhuma transação e nenhuma produção é utilizada como preço de desequilíbrio. Em vez disso, os preços são reduzidos para os bens com excesso de oferta e elevados para bens com excesso de demanda.

${ }^{163} \mathrm{O}$ leilão tem como função identificar as parcelas igualitárias e o leiloeiro não está entre aqueles que receberão essa parcela. Também não se deverá pagar qualquer taxa ou compensá-lo pelos custos. Ao contrário do que o seguro como mecanismo hipotético nos pergunta, não precisamos perguntar se as pessoas participariam do leilão se tivessem que pagar pelos seus custos. Ver nota de rodapé 3 em Dworkin (2002).
} 
Para que o mecanismo do leilão seja efetivo, precisamos de dois princípios fundamentais: o de autenticidade e o de independência. O princípio de autenticidade garante que as preferências dos imigrantes na ilha deserta são autênticas e não foram impostas por nenhuma entidade ou indivíduo. O princípio da independência afirma que suas escolham não são influenciadas por preconceito. A conseqüência disso é que se desenvolve uma teoria num contexto no qual as desigualdades socialmente geradas ficam de fora, já que é uma sociedade sem preconceito, racismo, etc ${ }^{164}$.

Outra hipótese assumida é que todos possuem talentos iguais, hipótese que relaxaremos mais adiante, e veremos suas conseqüências para a igualdade de recursos.

Depois de vários lances, chega-se ao estado em que ninguém inveja a cesta de outrem. ${ }^{165}$ Se invejasse, a pessoa poderia fazer um lance pelo bem desejado. Nas palavras de Dworkin, os custos de oportunidade estão igualados. Essa linguagem econômica será bastante útil aqui: quando deixamos de comprar alguma coisa por outra, ou deixamos de fazer um investimento por outro, o custo de aquisição do bem ou do investimento é o custo de oportunidade daquilo que deixamos de adquirir ou investir. Quando igualamos os custos de oportunidade, ficamos indiferentes entre os bens, não invejamos a cesta de bens das outras pessoas. Então, quando passamos pelo teste de inveja, as pessoas estão sendo tratadas como iguais, com igual consideração e as diferenças entre elas estão refletidas nos bens que adquiriram, isto é, que cada um dá valor à vida. Cada indivíduo será responsável pelas escolhas que fez no leilão.

Existirão situações de azar para alguns, supondo que na ilha não haja algumas das coisas que preferimos, ou que poucos preferem, tornando-as raras e caras. Mas isso não seria razão para invalidar a divisão a que se chegou, após ter passado pelo teste de

\footnotetext{
${ }^{164}$ Pierik e Robeyns (2007:141).

165 Esse processo poderá ser muito demorado, mas mesmo assim é a forma que Dworkin adota. Também estamos assumindo que temos apenas um equilíbrio, uma cesta especifica para cada imigrante, mas isso não invalida a possibilidade de vários equilíbrios. O importante é que o teste de inveja ateste a distribuição alcançada.
} 
inveja. Se estivéssemos buscando a igualdade de bem-estar, seria motivo para redistribuição de recursos.

Uma diferença importante é que as pessoas, sob a igualdade de bem-estar escolhem o tipo de vida que desejam sem levarem em conta o efeito de suas escolhas sobre as demais pessoas, mas na igualdade de recursos a situação é diferente. Quando vamos ao mercado, sabemos do custo das nossas escolhas sobre as pessoas e qual o estoque de recursos que pode ser utilizado, de forma equitativa. Ou seja, as nossas escolhas estão "limitadas" por uma quantidade de recursos finita que é disponível de forma que a parcela seja equânime. Na igualdade de bem-estar não temos esse limite. Aqui compreendemos melhor o papel do mercado/leilão como um mecanismo informacional que na igualdade de bem-estar não aparece, ou, nas palavras de Dworkin:

“O leilão propõe o que o teste de cobiça ${ }^{166}$ de fato assume, isto é, que a verdadeira medida dos recursos sociais dedicados à vida de uma pessoa seja determinada indagando sobre a real importância desse recurso para os outros. Repito que o custo, avaliado desta forma, aparece na noção que cada pessoa tem do que é seu com justiça, e no juízo que cada um faz da vida que deve levar, dado aquele mesmo comando da justiça”. (VS: 86)

A real importância do recurso de que o trecho fala é dada pelos custos de oportunidade. O leilão somente terá exercido o seu papel se as pessoas entrarem em igualdade de condições, a hipótese usada inicialmente para os imigrantes. No mundo real sabemos que isso não ocorre, mas a proposta de Dworkin é que esse mecanismo poderia proporcionar um padrão para julgarmos o quão a distribuição de recursos de uma comunidade é injusta ou desigual. Ele poderia ser utilizado como modelo para a construção de instituições que exerceriam sua função. No capítulo três de VS, o autor faz observações sobre como seria a aplicação da igualdade de recursos num mundo real.

\footnotetext{
${ }^{166}$ Na tradução para o português usa-se cobiça, mas ficaremos com a tradução mais utilizada, teste de inveja.
} 
Quando nos deparamos com a realidade, percebemos que as questões políticas têm forte impacto sobre a busca por uma justiça distributiva. Primeiro, se o leilão ou a nossa ida ao mercado não se dá de forma justa, já começamos desobedecendo a idéia de entrada em condições iguais. Mas o objetivo de uma teoria ideal é justamente dar o norte para as nossas políticas, iluminar o caminho mais correto.

O teste de inveja é atraente para uma concepção liberal de igualdade: primeiro porque evidencia que a injustiça está relacionada a ter menos recursos dadas as circunstâncias em que se vive, como pessoas com terras menos férteis. Segundo, ele pode acomodar as diferentes escolhas de planos de vida das pessoas ${ }^{167}$, alguns podem querer uma vida de sucesso no mercado de ações, outros podem preferir cultivar verduras orgânicas.

Podemos perceber que, diferentemente da igualdade de bem-estar, da igualdade de bens-primários de Rawls ou a das capacidades de $\operatorname{Sen}^{168}$, as quais defendem uma lista de bens que as pessoas deveriam possuir, a igualdade de recursos não tem e não busca determinar uma lista. As pessoas escolherão os bens ou recursos impessoais no mercado, de acordo com uma parcela justa que lhes cabe, e de acordo com sua concepção de boa vida. Essa é uma diferença importante, já que não apela para uma concepção concreta de boa vida. ${ }^{169}$ Reforça-se aqui a preocupação de que a igualdade liberal é neutra em relação às diferentes concepções de boa vida.

"By avoiding an appeal to such a concrete conception of well-being as the basis of its account of advantage, Dworkin's resource egalitarianism respects a widely affirmed liberal constraint, that government must not prescribe any concrete conception of the good

\footnotetext{
${ }^{167}$ Clayton (2002).

${ }^{168} \mathrm{Na}$ realidade, Sen não fecha uma lista das capacidades mais importantes, apenas enuncia que as pessoas têm diferenças nos seus funcionamentos e isso afeta a forma como cada um poderá utilizar os recursos em algo para sua vida. Por isso, Sen critica a idéia de uma lista de recursos, sendo que o mais importante é avaliar se as pessoas estão em igualdade de condições físicas e mentais para realizar algo com os mesmos. A preocupação de Sen não é com os meios (recursos), mas com os fins. Demais entusiastas da igualdade de capacidades, como Martha Nussbaum, trabalham na determinação dessa lista de capacidades.

${ }^{169}$ Clayton (2002:10).
} 
life for individuals or rely on such an account in the defense of its principles and policies.” Clayton (2002:10)

Precisamos agora assumir outros cenários para esses imigrantes para verificarmos se esse modelo ideal tem coerência. O que podemos perceber é que, ao entrarmos no mercado precisamos saber o que queremos, nossas vontades e ambições. Os imigrantes, ao contrário das partes da posição original, não estão sob um véu de ignorância tão espesso ${ }^{170}$. A justiça é tomada como pressuposto quando as cestas são escolhidas no mercado. Na posição original, é o momento em que se definem os princípios de justiça, assumindo o menor risco possível. Significa dizer que as partes na posição original querem garantir o cenário menos ruim, já que não sabem quais serão seus gostos, talentos, características pessoais. São avessos ao risco justamente por conta do véu de ignorância; além disso, não levam em conta os custos de suas escolhas na vida dos demais. Apenas se assume uma teoria rasa do bem, na qual as partes preferem mais bens primários do que menos.

Após o leilão e a posse de recursos, os imigrantes provavelmente decidirão produzir e comercializar, alterando a distribuição de recursos que não passará pelo teste de inveja, visto que com a produção e o comércio a divisão inicial deixa de existir. Se desconsiderarmos a hipótese de talentos iguais, os mais talentosos para as atividades de produção e de comercialização terão vantagens sobre os menos capazes, assim como nos casos de deficiências. Como a igualdade de recursos responde a essas situações? A igualdade de bem-estar, como vimos, nos obrigaria a distribuir mais recursos a fim de retornarmos a uma situação de igualdade de bem-estar. No entanto a nossa métrica é outra.

A igualdade de recursos busca igualar as pessoas nas circunstâncias para que possam realizar seus planos de vida, ou seja, nas condições em que entram no mercado. Assim, parece razoável que essa teoria distributiva tenha algo a dizer sobre os talentosos e

\footnotetext{
${ }^{170}$ Veremos adiante que o véu de ignorância de Dworkin é mais fino, as partes têm todas as informações acerca de si, mas não têm como afirmar se terão êxito ou se sofrerão a sorte bruta.
} 
sobre os deficientes. É moralmente inaceitável as desigualdades originárias dessas situações. A completa igualdade de circunstâncias é impossível de ser alcançada, mas podemos tentar mitigar as desigualdades que surgirem. Como não sabemos se vamos nascer com deficiências, ou desenvolvê-las no futuro, bem como com quais talentos vamos ser brindados, a sorte ou azar têm um papel importante nas nossas vidas.

Dworkin diz que há dois tipos de sorte, por opção e a bruta. A sorte por opção é resultado de nossas escolhas voluntárias. A sorte bruta é resultado de situações não programadas e aleatórias. $\mathrm{O}$ autor apresenta a possibilidade de um seguro hipotético que faria o elo entre os tipos de sorte, já que "transformaria” a sorte bruta em sorte por opção, mas ele não elimina a diferença entre elas. A que tipo de sorte a igualdade de recursos deve ser sensível?

A resposta de Dworkin é que não há motivos para refutarmos uma distribuição de recursos alcançada pelos indivíduos que se arriscaram mais (apostando nos fundos variáveis das bolsas, por exemplo) e que ganharam mais dinheiro. Aquele que escolheu não apostar, prefere uma vida mais segura. Na igualdade de recursos, as pessoas devem pagar o preço da vida que escolheram. O preço da vida mais segura é abrir mão de ganhos extras, por isso não podemos ser sensíveis a diferenças de sorte por opção. A mesma conclusão chegamos no caso de um indivíduo que se arriscou e perdeu. Ele assumiu a probabilidade de perda e de ganho no momento de sua escolha. Essa é a acomodação que o teste de inveja permite. As diferenças resultantes da ambição de cada indivíduo não devem ser compensadas.

Outro argumento em defesa da não redistribuição nos casos de sorte por opção é que, se os ganhadores fossem obrigados a compartilhar seus ganhos, não haveria incentivo para apostar. Mas mesmo sem este argumento, podemos dizer que a igualdade de recursos não exige que sejamos sensíveis às nossas escolhas deliberadas. Cada um estará pagando o verdadeiro preço dessas escolhas e as diferenças, daí advindas, são autorizadas. Estamos assumindo, como antes, que as pessoas entram em igualdade de condições, por isso têm à disposição todas as apostas possíveis. 
Já nos casos de sorte bruta nos quais não houve escolha, a resposta é que a igualdade de recursos deverá buscar uma forma de compensá-los e a forma encontrada por Dworkin é a de um seguro hipotético. Cada um de nós compraria um seguro contra a sorte bruta (contra invalidez, incêndio, etc). Esse seguro seria uma forma do governo ter um fundo para a compensação daqueles que efetivamente sofrerem por conta das contingências.

A pergunta que surge: as pessoas que não decidissem pagar pelo seguro contra catástrofes ficariam ao Deus dará? Dworkin não chega a invalidar atitudes paternalistas ou de ajuda do Estado em situações de catástrofe. Ele afirma que há uma razão para um seguro obrigatório mínimo que é o "princípio de correção” para essas externalidades, como obrigar a pagar um seguro mínimo de saúde; e outra razão é paternalista, na qual o Estado se compromete a proteger as pessoas de erros que poderão se arrepender depois, como obrigar ao uso do cinto de segurança ou do capacete para as motos. Para Anderson (1999), a igualdade de recursos não justificaria um seguro obrigatório. Assim., alguns decidiram pelo seguro de sua casa, e ocorre uma situação como o furacão, fizeram uma aposta correta. Deixou de adquirir outras coisas para comprar o seguro. Da mesma forma, se a tragédia não ocorrer, quem comprou o seguro fez uma aposta errada. Sabendo da probabilidade desses acidentes, optou por não comprar o seguro, é uma situação de sorte por opção. Porém, a igualdade de recursos não prevê compensação para aqueles que não adquiriram o seguro, por isso que um seguro mínimo é necessário ${ }^{171}$.

O objetivo da igualdade de recursos não é eliminar as apostas ou mesmo a sorte das pessoas, mas fazê-las iguais em termos de recursos para enfrentarem as incertezas. ${ }^{172}$ Não estamos comparando estados de bem-estar, mas os recursos que as pessoas teriam

\footnotetext{
${ }^{171}$ Dworkin (2009:246) afirma que o seguro é probabilístico e não paternalista, ou seja, algumas pessoas podem não comprar, mas assume-se que comprariam.

${ }^{172}$ Com essa afirmação, Dworkin quer negar que a igualdade de recursos possa ser denominada de "luck egalitarianism”. Para G. A. Cohen a função da igualdade é remover a sorte bruta. As principais diferenças entre este e a igualdade de recursos está na relação entre a responsabilidade e a igualdade, e como resolvem o problema dos gostos dispendiosos.
} 
para alcançá-los. O instrumento que teremos na igualdade de recursos para que as pessoas tenham as mesmas oportunidades de lidar com o risco é justamente o seguro. Essa é uma diferença fundamental entre igualdade ex ante e ex post. A igual consideração requer que a igualdade de recursos seja ex ante, ou seja, antes das pessoas enfrentarem os riscos e não depois que aconteceram ${ }^{173}$ como as teorias utilitaristas ou a justiça como equidade. Nas primeiras, as instituições devem buscar maximizar a felicidade geral ou média das pessoas e a última quer que os piores posicionados sobrevivam com o maior estoque de bens possível.

“(...) equality of resources means that people should be equally situated with respect to risk rather than that they be equally situated after the uncertainties of risk had been resolved.” Dworkin (2002:121).

Em seu livro mais recente ainda não publicado ${ }^{174}$, Dworkin interpreta a idéia de igual consideração e respeito reforçando o princípio da responsabilidade especial. Tratar as pessoas com igual consideração é fazer as pessoas iguais nos meios e não nos fins a serem alcançados. Para isso é preciso separar recursos pessoais de impessoais, e somente esses poderão ser distribuídos pelo mecanismo de mercado. Mas para que a teoria distributiva seja consistente com a idéia de responsabilidade pessoal, os recursos devem ser iguais ex ante.

\begin{abstract}
"Members of a political community should ideally begin their lives with equal material wealth: they should be ex ante equal. But since they make different decisions about education, occupation, consumption, and investment, they should not be equal in wealth ex post these transactions. Some should then be richer impersonal resources than others. This design, to the extent it is feasible, embodies an attractive interpretation of equal concern. We collectively treat ourselves with equal concern when the political settlement we construct makes each person's wealth depend only on the choices he made from an equal starting point." Dworkin (2009: 243).
\end{abstract}

\footnotetext{
${ }^{173}$ Dworkin acha que esclarece melhor essa questão no capítulo 9 de VS.

${ }^{174}$ Justice for Hedgehogs, draft. Boston University School of Law Conference, September, 25-6, 2009.
} 
Essa é a virtude soberana da comunidade política, tratar todos com igual consideração e respeito, interpretada como igualdade de recursos (impessoais) ex ante.

A justiça como equidade de Rawls é ex post, já que argumenta que a estrutura econômica de uma comunidade política deve ser construída de forma a fazer os piores posicionados o melhor possível. Evidencia-se aqui mais uma diferença importante, a teoria de Rawls não é sensível à escolha, ao contrário, os piores posicionados serão compensados independente se estão naquela posição por escolha ou por circunstância. Adicionalmente, o talento e a sorte vão influenciar a posição na pirâmide social ${ }^{175}$.

"We collectively treat ourselves with equal concern when the political settlement we construct makes each person's wealth dependent only on the choices he made from an equal starting point.” Dworkin (2009: 243).

Em Dworkin (2002), ele responde à falsa afirmação de que uma vez que as pessoas fizessem escolhas ruins, a comunidade não deveria ajudá-las com transferências adicionais de recursos, ou ainda classificando a igualdade de recursos como uma teoria da "linha de largada", na qual uma vez feita a distribuição de recursos ou oportunidades, não haveria nenhuma forma de compensação.

Na igualdade de recursos, não assumimos que uma vida melhor é aquela com mais dinheiro e poder, presume-se apenas que tratar as pessoas como iguais é permitir que cada uma defina seu plano de vida.

"Equality of resources protects individuals from disastrous economic mistakes through a scheme of taxation and welfare provision that is modeled on insurance that the average person in the community, acting prudently, would choose to buy if such insurance were available to all on equal terms.” Dworkin (2002:114).

${ }^{175}$ Seria parcialmente “endownment sensitive”. Ver em Dworkin (2002). 
No entanto, existem situações as quais não temos a possibilidade de recorrermos ao mercado de seguros, como o caso das deficiências que temos ao nascer, a cegueira por exemplo. Impossível antecipar essa situação ${ }^{176}$. A igualdade de bem-estar nos diria que devíamos compensar essas pessoas, mas não nos diz qual seria o limite para essa compensação. A teoria de justiça de Rawls assume um sistema justo de cooperação entre pessoas livres e iguais, mas trata de forma diferente a compensação das deficiências. Rawls ${ }^{177}$ de fato recomenda uma reparação para casos especiais, como a deficiência, mas não faz parte de seus princípios de justiça. Essa reparação se dá após a definição das instituições justas da estrutura básica da sociedade, particularmente no “estágio legislativo”. Pelo princípio de reparação, devemos compensar as desigualdades imerecidas como talentos naturais, características físicas, etc. Para tratar as pessoas como iguais, a sociedade deveria tratar as pessoas com desvantagens naturais com mais atenção. Isso faz parte da concepção de justiça, mas são os dois princípios de justiça que definem os arranjos justos. Mais importante, o princípio da diferença ${ }^{178}$ não é o princípio de reparação. O princípio de reparação

\begin{abstract}
“(...) não exige que a sociedade tente contrabalançar as deficiências, como se se esperasse que todos competissem em igualdade de condições na mesma corrida. Mas o princípio de diferença alocaria recursos para a educação, digamos, para elevar as expectativas de longo prazo dos menos favorecidos.” (TJ:121).
\end{abstract}

Ainda, segundo Rawls a distribuição dessas contingências não é justa ou injusta, o que é justo ou injusto é como as instituições lidam com essas diferenças.

\footnotetext{
176 Alguém poderia argumentar que com os avanços da genética seria possível antecipar a probabilidade de desenvolvermos doenças, mas a teoria de Dworkin não discute essa possibilidade e ainda podemos dizer que essa previsibilidade não está ao alcance de todos. Evidentemente, podemos ter casos nos quais teríamos uma capacidade preditiva maior. Famílias com casos de câncer podem contratar um seguro saúde com acesso a exames mais sofisticados para a detecção precoce da doença. Mas isso está mais para a discussão sobre o seguro de saúde mínimo ao qual as pessoas teriam direito. ${ }^{177} \mathrm{TJ}, \S 17$.

${ }^{178} \mathrm{O}$ princípio da diferença fornece também uma interpretação do que Rawls chama de princípio da fraternidade. Este estaria mais ligado à idéia de não querer ter mais vantagens, a menos que seja para o bem de quem está pior posicionado. Ver mais em TJ, pp.126-7.
} 
No entanto, Dworkin considera o seguro hipotético como a melhor alternativa para a compensação nos casos de deficiência. Na distinção entre escolhas e circunstâncias, em Dworkin (2002) rebate o questionamento de Fleurbaey sobre um tipo de visão determinística da escolha. Na igualdade de recursos, não há qualquer justificativa para a compensação de pessoas que possuem gostos dispendiosos, visto que isso não poderia ser considerado uma deficiência. Eu não consigo comer outra coisa senão lagosta com champanhe. Para Dworkin, não escolhemos as nossas convicções, gostos e preferências mais básicas, no entanto, podemos escolher agir de uma forma ou de outra ${ }^{179}$. Ele assume que nem sempre é fácil distinguir as nossas deficiências das nossas ambições e gostos ${ }^{180}$. Um exemplo é a preguiça, se for causada por uma doença pode ser compensada, mas como apresentar isso para uma companhia de seguros? Ninguém está proibido de ter gostos excêntricos ou extravagantes, mas apenas se exige que pague pelos custos dos mesmos, medidos pelo impacto que suas escolhas geram nas outras pessoas.

\begin{abstract}
"Determinism is a thesis about action: it denies that choice is genuine. I said in Sovereign Virtue that the metaphysics I assume is not determinism but rather the metaphysics of freedom that underlies what I called "ordinary people's ethical experience". (...) Equality of resources does not suppose that people must somehow pay just for having expensive tastes or demanding ambitions. It supposes only that when they choose to satisfy those tastes or pursue those ambitions they should pay the cost of doing so, measured by the impact of their choices on others. They are not excused from that responsibility just because their choices are motivated rather than whimsical." Dworkin (2002:118-9)
\end{abstract}

Kymlicka (2006) afirma que a proposta de Dworkin se assemelha à proposta de Rawls na posição original, já que devemos imaginar as pessoas, nesse caso, sob um véu de ignorância modificado. Cada um de nós não sabe o seu lugar na distribuição de talentos ou de deficiências que podem surgir. Precisamos assumir a probabilidade diante de situações que nos desfavoreçam. Pergunta-se a cada um quanto estariam dispostos a pagar por um seguro contra serem desfavorecidos de alguma forma, ou por

\footnotetext{
${ }^{179}$ Ele exclui casos patológicos.

${ }^{180}$ Dworkin (2002:119).
} 
falta de algum talento ou por alguma deficiência. O seguro hipotético serviria de guia para um sistema de tributação que redistribuísse os recursos conforme os prêmios contratados de cada um. Os imigrantes da ilha são indivíduos com diferentes graus de aversão ao risco. Alguns se arriscarão mais em seus negócios e nas suas vidas, outros preferirão o aconchego de uma vida mais simples. Em Rawls, dado o véu de ignorância da posição original, todos são conservadores e avessos ao risco.

Aqui está mais uma das diferenças importantes entre Dworkin e Rawls, a existência de parâmetros que determinem compensações em situações imerecidas. Para o primeiro, o destino das pessoas deve ser determinado pelas suas ambições e não pelos seus dotes naturais. ${ }^{181}$ Para Rawls, essa questão está fora da discussão, visto que na lista dos bens primários ficaram fora os recursos pessoais, na linguagem de Dworkin. Rawls insiste que a sua teoria se preocupa com as desigualdades que afetam as oportunidades de vida das pessoas e não das provenientes das escolhas. Até aqui se parece muito com a igualdade de recursos, mas o princípio da diferença oferece uma forma de identificar o que foi escolhido e o que foi mero acaso.

\begin{abstract}
"Rawls himself claims that his list of primary goods is justified by means of an ideal-based account of citizen's needs rather simply an empirical description of the content of preferences. These needs are twofold. Each individual has an interest in developing and deploying a sense of justice and the mental and physical capacity to form, revise, and rationally to pursue a conception of the good life. More recently, he also stresses that the relevant ideal is a "political" conception of person's capacities and interests, which can be endorsed by individuals who told competing conceptions of well being." Clayton \&Williams (1999: 954)
\end{abstract}

Mas a decisão de uma pessoa para adquirir determinado seguro contra possíveis deficiências dependerá do que cada um planeja para sua vida. Cada um irá valorizar o que é importante para a realização desse plano ${ }^{182}$. Mas quem nasce com uma deficiência já parte dessa "limitação" para traçar seu plano de vida. As nossas

\footnotetext{
${ }^{181}$ Kymlicka (2006).

${ }^{182}$ Se a probabilidade de adquirir, ao longo da vida, uma deficiência fosse igual para todos, faria sentido falarmos num fundo comum de recursos que seria formado pelos prêmios pagos por todos os indivíduos, que por sua vez contratariam um seguro. Mas essa probabilidade é distribuída aleatoriamente pela loteria dos genes.
} 
faculdades físicas e mentais também não podem ser consideradas como parte dos recursos impessoais, afirma Dworkin, apesar de serem fundamentais para uso em conjunto com os demais recursos necessários aos planos de vida, fazem parte dos nossos recursos pessoais e não podem ser transferidos ou manipulados. Ainda que fossem, como determinar o padrão normal dessas faculdades para definirmos o montante da compensação? A forma de compensação será dada pelo seguro, mesmo que nenhum dinheiro do mundo seja capaz de compensar a deficiência de uma pessoa. É uma teoria do "segundo melhor"183, tentamos fazer o possível para compensar as circunstâncias imerecidas. Porque é melhor buscar uma forma de mitigar essas diferenças do que ignorá-las. A teoria das capacidades de Amartya Sen se aproxima de Dworkin quando estamos falando de compensações. Em Sem, sabemos que há uma preocupação com a capacidade de cada um realizar seus "funcionamentos", mas, segundo seu autor, sua preocupação está com os fins e não com os meios. Adicionalmente, Sen afirma que as diferenças entre as pessoas na teoria de capacidades é um objeto da discussão pública e no caso da igualdade de recursos está nas mãos de "operadores atomizados" do mercado de seguro ${ }^{184}$. Somos diferentes na nossa condição metabólica, emocional, física, que implicam sérias desigualdades imerecidas. Na igualdade de recursos elas também são moralmente inaceitáveis.

Otsuka (2002) afirma que a demanda da igualdade de recursos em casos de doença ou deficiências nos obrigaria a transferir recursos das pessoas saudáveis até elas ficarem famintas, e assim todas ficariam igualmente miseráveis, como exigiria o teste de inveja. Mas Dworkin afirma que há um erro de interpretação do teste de inveja. Ele não requer que fiquemos indiferentes entre as combinações dos seus recursos pessoais e impessoais e a combinação dos recursos pessoais e impessoais das outras pessoas, mas que as pessoas se coloquem na posição que provavelmente ocupariam se tivessem a chance de contratar um seguro contra doença, ou contra deficiências, em termos equânimes. Significa que a versão do teste de inveja, segundo Dworkin, toma essas

\footnotetext{
${ }^{183}$ Kymlicka (2006: 104)

${ }^{184}$ Sen (2009).
} 
desvantagens ex ante, por isso não faria sentido nivelar as pessoas por baixo. Ainda, o próprio princípio da igual consideração não permitiria transferências que levassem um grupo de pessoas à fome.

As pessoas podem considerar que alguns de seus desejos e preferências sejam deficiências. Para Dworkin, quem tem gostos excêntricos não tem nem mais nem menos recursos materiais que os outros. É o preço que se paga por esse bem no mercado.

Outra questão que a igualdade de recursos deverá responder é como ficam as diferenças de talento e se devemos redistribuir os recursos dos talentosos para os não tão talentosos. Dworkin afirma que alguém poderá ter um talento especial para produzir tomates e vender o excedente de produção. Esse talentoso produtor de tomates terá mais recursos materiais à sua disposição e os outros poderão invejar sua situação. Se algumas pessoas decidem trabalhar arduamente para satisfazerem suas preferências dispendiosas ou não, a igualdade de recursos não vê razão para negar. As pessoas pagarão o preço pelos recursos materiais que vão utilizar para esse trabalho árduo. Não há diferença entre isso e uma vida frugal, já que ambas foram escolhidas no mercado. Para essa conclusão, precisamos introduzir no mercado o tipo de ocupação que desejamos ter, assumindo que todos tenham o mesmo talento, assim as pessoas invejariam a vida de outrem como um todo e não apenas o que consomem. O teste de inveja requer "que ninguém deseje a parcela de ocupação e recursos à disposição de qualquer pessoa no decorrer do tempo, embora alguém possa cobiçar a parcela de outra pessoa em determinado momento.” 185

Faz todo o sentido, porque se as pessoas estão em igualdade de condições no mercado, elas poderão escolher as ocupações que desejar e poderão adquirir mais recursos para o consumo. Mas aqui estamos considerando a igualdade de talento, que não se verifica no mundo real. A igualdade de recursos busca nos igualar nos recursos externos, dadas 
as nossas características físicas e psicológicas. Isso não significa dizer que a distribuição de recursos precisa permanecer igual ao longo do tempo. Isso diferencia, por exemplo, a igualdade de recursos da igualdade de oportunidades. Esta alcançada, a prosperidade de um não afetaria as outras pessoas e dado que a igualdade inicial foi garantida, tudo o que vier depois é justo. Sabemos que na igualdade de recursos as nossas escolhas impõem custos aos outros. Se o talentoso produtor de tomates não fosse tão competente, outro menos competente poderia vender seus tomates e ter mais recursos $^{186}$.

A igualdade de recursos deve ser sensível às nossas escolhas (à ambição) e insensível às nossas características inatas provenientes da loteria genética. Se continuarmos a insistir que o teste de inveja é condição necessária para uma distribuição igualitária, o talento precisa ser neutralizado. Uma possível solução seria uma redistribuição periódica de recursos via algum sistema de taxação da renda. Importante destacar que é o imposto sobre a renda porque os demais recursos foram distribuídos de forma equânime e o que queremos são os recursos externos provenientes do trabalho, sem considerar a herança ou outros impostos. Mas como determinar a taxação na renda gerada pela diferença de talentos? Essa tarefa parece ser infrutífera, mas Dworkin assume que o problema dos talentos seria o mesmo das deficiências. Ou seja, a forma seria a do seguro hipotético, perguntando quanto cada um estaria disposto a pagar na eventualidade de não ter determinado talento ou habilidade e isso ser convertido nas taxações sobre a renda. A forma como o autor apresenta o seguro para o talento (ou falta dele) é complexa, por isso vamos resumir suas principais premissas.

Um mercado de seguro nos protege de situações sobre as quais não temos controle. Existem seguros de saúde, residência, carro, vida, etc, mas seguro para a falta de talento traz uma dificuldade adicional, não se sabe exatamente quanto uma pessoa

\footnotetext{
${ }^{186}$ A teoria de Dworkin não tem como meta eliminar a inveja no sentido psicológico do termo. As pessoas vão continuar invejando as outras, ou porque são mais bonitas, mais simpáticas, etc. Sobretudo em relação aos recursos pessoais.
} 
pode ter de rendimento econômico. É o mesmo véu de ignorância modificado que citamos anteriormente. Muitas vezes levamos a vida toda para aprimorar uma habilidade. Quantas obras magníficas foram realizadas por pessoas na meia idade ou no fim de sua vida? Bem, retomando nossa tarefa, a melhor forma de resolver esse ponto é assumir de forma simplificada uma curva média de seguro.

“Como no caso das deficiências, optei por fazer com que o pagamento
dos prêmios e, portanto, dos impostos ficasse no nível médio de
cobertura para simplificar. Eu poderia, naturalmente, ter escolhido a
mediana ou a modalidade de cobertura selecionada no mercado
hipotético, em vez da média. Optei pela média na suposição de que
nossa avaliação de probabilidade de erro em casos especiais
(probabilidade de que o prêmio extraído difira do que o indivíduo em
questão teria realmente pago no mercado hipotético) expressasse a
quantia e também o fato dessa diferença." (VS: 134, nota 14)

Obviamente, mesmo com o mercado hipotético de seguros não chegaremos à perfeição. O objetivo de Dworkin é criar algum mecanismo que oriente a sociedade na direção da igualdade. Como princípio econômico de um mercado de seguros, quanto maior a probabilidade daquilo contra o qual queremos nos proteger, maior será o valor pago pelo segurado, ou seja, o prêmio. As empresas seguradoras levam em conta uma série de características dos indivíduos para determinar as probabilidades de ocorrer o que estamos tentando evitar. Um exemplo típico é o caso do seguro de carros. Em geral, mulheres com filhos têm um seguro menor porque seriam mais cuidadosas no volante ${ }^{187}$.

Como ficaria o caso de talento? Cada um de nós poderia comprar um seguro contra a falta de talento para alguma ocupação, mas se ela gerar um retorno muito elevado, já que se trata de um talento raro, a probabilidade de não alcançarmos esse patamar é tão alto que, ou o prêmio será altíssimo, e ficaremos a vida toda tentando pagar, ou o mercado de seguros nem irá oferecer essa possibilidade já que o prejuízo é certo. Isso Dworkin chamou de “escravidão dos talentosos”. Portanto, usar uma “ocupação”

\footnotetext{
${ }^{187}$ Como isso é uma comprovação estatística média, as solteiras podem ficar revoltadas com essa “discriminação” no mercado.
} 
média faz sentido porque aproxima a maioria da população desse patamar e torna o cenário viável. Importante a destacar é que o seguro não é vantajoso financeiramente. As pessoas não irão ao mercado para adquirir seguro pensando em ganhar uma renda permanente maior do que a do fruto de sua ocupação. O seguro precisa ser pago e, quem contratar, abrirá mão de parte dos recursos para garantir, pelo menos, que sua renda não diminua. Dworkin imaginou o seguro hipotético pensando os seguros desemprego e contra acidentes existentes no mundo real. Ou seja, as pessoas levarão em conta os custos dessa contratação, que serão transformados numa estrutura de impostos. Não existe "almoço grátis”, portanto, para que o governo trate as pessoas com igual consideração e respeito, essa estrutura de impostos deverá servir para dar conta da tarefa.

"My claim is that theories of distributive justice should use a metric of resources rather than a metric of welfare to describe their goals and that a distribution is genuinely egalitarian only if it satisfies as well as possible the goals of equality of resources.” Dworkin (2002:130).

As pessoas então teriam a mesma oportunidade para se protegerem da falta de alguma habilidade ou talento e poderiam se proteger com acesso igualitário a um mercado hipotético de seguros. Esta é a maior preocupação da igualdade de recursos.

Continuarão existindo as pessoas que ganharão muito mais do que as outras, mas isso a igualdade de recursos não condena. Talvez porque o autor espere que seja a realidade de uma minoria, como os exemplos dados por ele: astros de cinema, jogadores de beisebol (ou um Ronaldo no futebol), empresários. Aqui não temos como passar no teste de inveja, visto que os grandes gênios sempre irão existir e não haverá seguro capaz de compensar.

O mercado de seguros como modelo para uma taxação redistributiva tenta unir dois mundos: o mundo daqueles sem talento que arcam com todas as conseqüências dessa desvantagem, e o mundo no qual se mantêm essas diferenças ou desvantagens 
relativas, mas todos podem se proteger, antecipadamente, para mitigá-las com o seguro. A igualdade de recursos dá preferência ao segundo mundo.

Dworkin não nos apresenta uma solução final e incontestável para os casos de disparidades de renda provenientes das diferenças de talento. Apenas aponta para o fato de que um ideal defensável de igualdade deve considerar um programa redistributivo para as diferenças de talento, visto que não são frutos da escolha, é a sorte ou azar bruto. No mundo real, a taxação progressiva, ou seja, à medida que aumenta a renda, a percentagem de tributação cresce, existe nos países mais desenvolvidos, chegando a tributos sobre fortunas de 90\%. Isso não tem desestimulado ou reduzido o crescimento desses países, ao contrário, permitem que toda a população tenha à disposição os melhores serviços públicos de saúde, educação, segurança, auxílio desemprego e toda a sorte de esquemas de proteção social. Outra questão que devemos abordar é que a igualdade de recursos não parece nos ajudar a resolver situações de extrema pobreza, as quais poderíamos classificar como tragédias e catástrofes. Amartya Sem, com sua abordagem de capacidades, parece oferecer uma alternativa mais adequada para essas situações extremas. De forma diferente, ele também aponta para um ideal de igualdade que se preocupe com as diferenças de "talento" ou dos funcionamentos. O que parece mais adequada para as deficiências de que falamos.

\footnotetext{
"For unlike many welfarist and capability views, the test provides an account of interpersonal comparison which does not rest on the truth of contested claims about personal well being. Instead individuals themselves decide what is to count as a valuable resource or opportunity, and what is to count as a limitation or a handicap. Because the widespread disagreement about the nature of personal well-being characteristic of our pluralistic societies, many liberals will applaud this feature." Clayton \&Williams (1999:457)
}

A igualdade de recursos também não nos dá resposta, como o próprio autor nos aponta, para casos de mudança do valor que damos para a vida. E se queremos começar tudo de novo, teremos direito a mais recursos? Também não considera o problema da herança, pessoas que já teriam uma vantagem dada pelos seus pais. 
Dworkin não espera responder a todas essas questões, mas apresentar uma teoria da justiça na qual a igualdade considere as diferenças entre os indivíduos na forma como apresentamos anteriormente, de sorte por opção e bruta. A sorte por opção levanta um princípio do individualismo ético importante que é a responsabilização especial. Devemos ser responsáveis pelas nossas escolhas e não podemos exigir que os outros paguem por nossas escolhas boas ou ruins. Do outro lado, a igualdade de recursos nos “protege”, pois também se baseia em outro princípio no qual toda a vida vale a pena e para isso devemos ter a liberdade de escolhermos no mercado o que consideramos de importante para o nosso plano de vida. Ou seja, como indivíduos, somos tratados como iguais.

Se a igualdade de bem-estar nos atrai porque dá importância ao que realmente desejamos, a igualdade de recursos também nos permite a mesma conclusão. As nossas aspirações comandam nossas decisões no mercado hipotético e essa carga informacional que os imigrantes da ilha deserta possuem, mas que poderia ser aplicada às pessoas do mundo real, será o núcleo da ética dessa igualdade. Saber o que desejamos implica saber o que vamos “adquirir” nesse “mercado da vida”, bem como os custos que vamos impor aos outros. Vale a pena a citação seguinte, que resume os objetivos de Dworkin ao apresentar a igualdade de recursos:

\footnotetext{
"Quando entendemos a importância, na igualdade de recursos, da exigência de que qualquer teoria da distribuição deva ser sensível às aspirações, e entendemos os efeitos gerais que qualquer programa de distribuição ou redistribuição na vida que quase todas as pessoas da comunidade querem e têm permissão para levar, devemos encarar com desconfiança qualquer afirmação categórica de que a igualdade de recursos precisa apenas ser definida de maneira a ignorar esses fatos. A igualdade de recursos é um ideal complexo. É, provavelmente (assim como afirmam os diversos argumentos que discutimos aqui), um ideal indeterminado que aceita, dentro de certa variação, uma série de distribuições. Mas esta parte parece clara: qualquer concepção defensável desse ideal deve estar atenta para as suas diversas dimensões, e não rejeitar de antemão a exigência de que seja sensível ao custo de vida de uma para outra pessoa. A presente sugestão de que as genuínas teorias de igualdade devem se preocupar somente com a quantidade de bens disponíveis ou ativos líquidos no poder das pessoas em determinado momento, é um dogma pré-
} 
analítico que não protege de fato as fronteiras do conceito de igualdade da confusão com outros conceitos, mas, pelo contrário, distorce a tentativa de exprimir a igualdade como um ideal político independente e poderoso." (VS: 141).

Ao aceitarmos a igualdade de recursos como parametrizada pelos efeitos que a nossa posse de recursos produzem sobre as demais pessoas, buscamos aquilo que Dworkin preconiza, de que os indivíduos dessa sociedade se importam, de alguma forma, com os demais. Guest (2009) explica, sinteticamente como a nossa vida moral é parametrizada por meio da sensibilidade de nossas escolhas sobre os outros e a métrica dessa sensibilidade é dada pelo leilão, pelo mercado e pelo seguro.

“ (...) he uses familiar economic devices to provide a metric of sensitivity in the form of moral conditions for ownership (the auction), transfer (the ideal market) and compensation (hypothetical insurance)." Guest (2009: 362).

Parece que Dworkin quer um habeas corpus preventivo para uma teoria que deixa algumas lacunas; porém, ao contrário, ele está plenamente consciente de que as pessoas, ao longo de sua vida, vão mudar suas preferências, e poderão se ver diante de dificuldades ou recompensas inesperadas. Termos vários equilíbrios não invalida a teoria. Na verdade, a igualdade inicial de recursos não basta, é preciso considerar o indivíduo em si, sua capacidade relativa de realizar projetos. Sendo que a vida não deve ser desperdiçada, que todos têm o direito às escolhas que busquem realizar esse plano, as circunstâncias não escolhidas devem ser mitigadas de alguma forma. Essa forma ainda a ser desenvolvida é a da redistribuição de renda via impostos progressivos. Os recursos são apenas um aspecto do ideal de igualdade proposto por Dworkin.

Para Kymlicka (2006), a teoria de Dworkin foi uma resposta aos problemas da teoria de justiça de Rawls, assim como esta foi uma resposta ao utilitarismo. Arrisco a dizer que foi muito mais do que isso, porque deseja integrar nossas concepções de 
igualdade, liberdade e comunidade com um arcabouço institucional para definir direitos e deveres dos cidadãos baseados no princípio abstrato da igual consideração.

Em VS, Dworkin propõe construir concepções daquelas várias virtudes políticas a fim de integrar a política com uma noção geral da ética, ou seja, mostrando porque é importante que a vida seja de sucesso e o que esse sucesso significa. ${ }^{188}$

A igualdade de recursos também foi construída de forma a não entrar em conflito, sobretudo, com a liberdade. Como vimos no primeiro capítulo, os conceitos são interpretativos e agora estamos aptos a utilizar o método de Dworkin para a liberdade e a igualdade.

\subsection{A liberdade e seu lugar na igualdade de recursos}

Nesta seção, vamos discutir como fica o lugar da liberdade na teoria distributiva de Dworkin, considerando que já apresentamos o seu modelo de justificação moral. Para enriquecer a apresentação, acrescentaremos alguns outros conceitos sobre direitos, especificamente para dar conta da liberdade como conceito interpretativo.

Em LDS, Dworkin afirma que a relação de conflito entre liberdade e igualdade precisa ser tratada, visto que ela molda a nossa vida como entes políticos.

"Com exceção dos extremistas, portanto, todos reconhecem a
necessidade de se chegar a um acordo entre a igualdade e a
liberdade. Qualquer parcela de legislação social importante, desde a
política tributária até os projetos de integração, é moldada pela
suposta tensão entre esses dois objetivos. Esse suposto conflito entre
igualdade e liberdade é que tenho em mente quando pergunto se
temos um direito à liberdade, como supunham Jefferson e tantos
outros. Trata-se de uma questão crucial. Se liberdade de escolher a
própria escola, os próprios empregados e o lugar onde se vai morar é

${ }^{188}$ Dworkin (2002). 
simplesmente algo que todos queremos, tal como ar-condicionado ou lagostas, então não temos o direito de nos apegar a essas liberdades em face do que aceitamos como os direitos dos outros a uma igual quota de respeito e recursos. No entanto, se pudermos dizer não simplesmente que desejamos essas liberdades, mas que também temos direito a elas, teremos pelo menos estabelecido uma base para exigir compromisso." (LDS: 410-11)

Todos querem ter o direito de escolher onde estudar, o que comer, por onde andar, mas a questão importante a ser tratada é se estamos qualificados ${ }^{189}$ para ter esse direito. Ele não acredita simplesmente que temos o direito à liberdade. Em resumo, ele acredita que estamos aptos a alguns direitos especiais e que seriam classificados como tais de acordo com o impacto que teriam sobre outras virtudes. Devemos encontrar uma forma de justificar esses direitos no campo da moralidade, dizendo que é errado privar as pessoas de certas liberdades, independente do impacto sobre o bem-estar geral.

Como diz a citação anterior, Thomas Jefferson acreditava que as pessoas tinham direito à liberdade. Para Dworkin, não existe esse direito geral à liberdade e essa forma de pensar nos leva a uma tensão entre liberdade e igualdade. Devemos pensar a liberdade de outra forma e precisamos começar a entender o que significa a palavra “direito”. Ela é utilizada de diversas formas no direito e na filosofia. Para ele o que vale é o direito no seu sentido forte, ${ }^{190}$ que tem a seguinte conseqüência:

"Se uma pessoa tem um direito a alguma coisa, então é errado que o governo a prive desse direito, mesmo que seja do interesse geral proceder assim.” (LDS: 414)

O governo não pode se valer de um argumento utilitarista para ferir a liberdade de nenhum cidadão. Com esse conceito, não existe a noção de um direito geral à liberdade, quer dizer, não significa que temos direito a toda liberdade possível, mas a

\footnotetext{
189 A tradução para português traduziu "entitled to them” como "ter direito a", mas creio que "qualificado para” traduz melhor o significado da discussão do autor. Temos que preencher alguns requisitos para justamente ter o direito à liberdade no sentido dworkiano. Ver LDS, p. 411 e no original, p. 267.

${ }^{190}$ Ver LDS, capítulo 7.
} 
algumas liberdades básicas ou importantes. Entre estas está a liberdade de expressão, por exemplo. Mas o que significa dizer que temos direito apenas a liberdades básicas? Vamos usar o exemplo do autor em duas situações: a primeira, o governo proíbe a liberdade de expressão nas questões políticas e a segunda, o governo institui mão única numa via. Nos dois casos, temos restrição à liberdade, mas há uma diferença que tem a ver com o caráter especial da liberdade envolvida no caso coberto pelo direito. Quando restringimos uma liberdade básica, o impacto dela vai além do efeito sobre a liberdade em si, ela também afeta outras virtudes envolvidas. Por isso precisamos abandonar a idéia de um direito geral à liberdade.

“A idéia de um direito à liberdade é um conceito equivocado que,
pelo menos em dois sentidos, presta um desserviço ao pensamento
político. Em primeiro lugar, a idéia cria a falsa noção de um conflito
necessário entre a liberdade e outros valores, naqueles casos em que
uma regulamentação social é proposta, como no programa de
transporte escolar compulsório. Em segundo lugar, a idéia oferece
uma resposta excessivamente fácil à questão de por que consideramos
certos tipos de restrições como especialmente injustas, como, por
exemplo, a restrição à expressão ou à liberdade religiosa. A idéia de
um direito à liberdade nos permite dizer que essas restrições são
injustas porque têm impacto especial sobre a liberdade enquanto tal”
(LDS: 417)

Se estamos desconsiderando esse direito geral à liberdade, como devemos justificar que nas democracias modernas os cidadãos têm direitos como de expressão, atividade política e religião? A resposta de Dworkin é que devemos encontrar a justificativa no terreno da moralidade e o argumento central não será o conceito de liberdade, mas de igualdade. Será a igualdade de recursos que nos dará a justificativa moral para defender as liberdades fundamentais. Não ficaremos com uma resposta utilitarista de que a sua defesa gera benefícios para o bem-estar geral e também não ficamos no terreno do dogmatismo vazio ao dizer que a liberdade tem valor intrínseco e, por isso, deve ser defendida.

Assumimos o postulado da moralidade política de que o governo deve tratar a todos com igual consideração e respeito, que irá formar o conceito liberal de igualdade. Ao 
conceito de igual consideração e respeito estão associados dois direitos, já descritos anteriormente, o de ser tratado igualmente e o de ser tratado como igual. Sabemos que Dworkin toma o direito de ser tratado como igual como o fundamental sob a concepção liberal de igualdade. O direito mais restritivo de tratar igualmente valeria apenas em algumas ocasiões especiais, mas sempre partindo do direito fundamental ${ }^{191}$. Os direitos individuais fundamentais devem ser reconhecidos quando o direito fundamental de que todos devem ser tratados como iguais assim demandar. Se isso estiver correto, ele diz, então não há razão para que essas liberdades entrem em choque com a igualdade. Vamos apresentar em seguida forma na qual se dará essa demanda ao esclarecer o lugar da liberdade na igualdade de recursos.

Em outro texto, Dworkin afirma que o conflito entre a liberdade e a igualdade é uma ilusão e tem um propósito político, o de apelar ao valor da liberdade como uma desculpa para ignorar a igualdade ${ }^{192}$. Ele também acredita, como veremos, que as pessoas não acham que a igualdade deva sempre ser preterida em nome da liberdade. Isso ocorre porque elas discordam a respeito do que a igualdade requer ou de seu conceito genuíno. Se a liberdade fosse tão importante que, em nome dela, abríssemos mão da igualdade, deveríamos saber dizer o por quê. A idéia de que a liberdade tem essa importância é repetida tantas vezes que se torna verdade, mas é uma ilusão. A causa principal do falso conflito, como salientado no primeiro capítulo, está na forma como definimos essas virtudes.

Dworkin pensa na liberdade utilizando a definição de Berlin de liberdade negativa:

\footnotetext{
${ }^{191}$ Ele cita os reapportionment cases. São casos que questionavam a forma como cada distrito dos Estados Unidos devia votar e a representação de seus cidadãos, que violava a $14^{\mathrm{a}}$. Emenda Constitucional, da igual proteção das leis para todos. Como resultado de um dos casos (Gray v. Sanders), a Corte formulou o princípio "one-person, one-vote" para a legislatura dos estados, determinando que cada pessoa tem o mesmo peso na votação de cada distrito. Esses casos foram reunidos com o nome de reapportionment cases nos anos 1960. Nesses casos, o direito mais restrito foi aplicado.

${ }^{192}$ Dworkin (2001).
} 
"Tenho em mente a definição tradicional de liberdade como a ausência de restrições impostas pelo governo ao que um homem poderia fazer, caso desejasse” (LDS: 411).

Dada essa definição, liberdade e igualdade estão em conflito. Essa concepção de liberdade é chamada por Dworkin de "license-neutral”, ou seja, é neutra em relação ao que os indivíduos desejam para suas vidas. A liberdade será afetada se impedirmos alguém de ter relações sexuais como gosta, assim como quando proibimos de roubar ou matar. Para esses últimos dois casos, encontramos uma justificativa para a restrição. Para Berlin, qualquer lei, mesmo as justificáveis, já que estão protegendo a vida ou a propriedade, são uma infração à liberdade.

No conceito de liberdade como licença, teremos o conflito com a igualdade porque não há uma distinção de comportamentos, qualquer lei diminui a liberdade de alguém, as boas e as ruins. Portanto, o que é importante saber, não é se a liberdade é atacada pela lei, mas se esse ataque é justificado por algum valor em competição, como a igualdade ou a preservação da vida ${ }^{193}$.

"Se um filósofo social atribui um valor muito alto à liberdade como licença, ele pode ser entendido como se estivesse argumentando que esses valores contrastáveis têm um valor relativo mais baixo. Se ele defende a liberdade de expressão, por exemplo, por meio de algum argumento geral em favor da licença, então seu argumento também apóia, pelo menos, pro tanto, a liberdade de formar monopólios ou de apedrejar vitrines de lojas.” (LDS: 405).

Dworkin não aceita a liberdade como licença, mas a liberdade como independência no sentido de Mill. Nesse sentido, a liberdade é o status de uma pessoa como independente e igual ao invés de subserviente. É um conceito que discrimina os comportamentos entre aqueles que protegem a vida e aqueles que a insultam e desrespeitam. $\mathrm{O}$ alcance desse conceito é ainda mais amplo:

\footnotetext{
${ }^{193}$ Ver capítulos 11 e 12 de LDS.
} 
"Mill via a independência como uma dimensão adicional da igualdade; argumentava que a independência de um indivíduo é ameaçada não simplesmente por um processo político que lhe nega voz igual, mas por decisões políticas que lhe negam igualdade de respeito." (LDS: 405).

A liberdade está relacionada com conceitos morais de dignidade, personalidade e insulto. Para Mill, a liberdade é mais complexa que a simples noção de licença. A independência da personalidade é uma condição para uma sociedade justa e não significa anarquia.

O que temos atualmente é uma confusão de conceitos que acaba favorecendo a liberdade e afetando outras virtudes. Dworkin sabe que essa confusão não é apenas entre os filósofos, mas na vida política em geral.

"Conservadores confundem estas idéias quando usam "permissividade" para descrever a independência sexual e a violência política e para sugerir que estas diferem apenas em grau. Os radicais confundem essas idéias quando identificam o liberalismo com o capitalismo e, portanto, supõem que os direitos individuais sejam responsáveis pela injustiça social. (LDS: 408)

\subsubsection{Tipos de Conceitos}

Mais do que um novo conceito de igualdade, a igualdade de recursos busca conciliar a liberdade com a igualdade e a moralidade com a ética.

Para Dworkin, o conceito de igualdade é um ideal que os governos devem almejar para seus cidadãos, mas é um conceito misterioso ${ }^{194}$. Somos iguais em uma dimensão, mas não em todas, assim, o que vamos igualar?

${ }^{194}$ VS: 3. 
O objeto da discussão será a igualdade distributiva e a definição da melhor teoria para alcançar nosso objetivo, que é a virtude soberana do Estado, tratar a todos com igual consideração.

A idéia de que os conceitos são interpretativos é fundamental para todo o trabalho de Dworkin não apenas para chegarmos a um ideal político atraente, mas para evitar conflitos entre valores políticos. A definição de igualdade como igualdade de recursos tem também como princípio evitar o conflito com a liberdade, mas antes de tudo é um conceito que captura o que é bom na virtude em questão, longe de ser apenas instrumental e vazio.

“(...) to help us to see why it is a cause for regret when people are cheated of liberty or equality.” Dworkin (2001:256)

O argumento é que se usarmos, por exemplo, a definição de Berlin de liberdade negativa, a ideia de podermos fazer o que quisermos sem a interferência dos outros e, se definirmos a igualdade como todos tendo a mesma riqueza, independente das escolhas que façamos entre trabalho e lazer e entre investimento e consumo, o conflito está dado. Com as definições acima, para garantir a igualdade de riqueza devemos proibir o roubo assim como o comércio, por exemplo, limitando a liberdade. A proibição do comércio se explicaria porque ele geraria desigualdades, uma vez que pessoas com talento para o negócio e com habilidades específicas terão um desempenho melhor, venderão mais e acumularão mais renda. No primeiro caso, a proibição é até aceitável, mas no segundo, não. Por isso, definir a igualdade e a liberdade propriamente é o primeiro passo para uma nova teoria liberal da igualdade.

As definições tradicionais, nas quais o conflito é inevitável, são chamadas de "rasas" (flat conceptions) e as definições nas quais liberdade e igualdade não estão em conflito, dinâmicas (dinamic conceptions) ${ }^{195}$. Para ele, esses conceitos são

${ }^{195}$ Dworkin (2001:254). 
interpretativos. Precisamos entender em que essas virtudes realmente consistem, seus limites, o que justifica uma análise filosófica para nos dizer o que realmente são e não o que poderiam ser. Dworkin utiliza uma comparação interessante, diferente do ouro, que tem a sua composição química e elementos fixos que definem o que é ouro, e as virtudes que sofrem influência dos nossos desejos e ambições. Diz ele:

"They [as virtudes] are what they are because we are what we are: we believe that a government that respects liberty and equality in some way improves the lives of those whom it governs. Liberty and equality are not natural kinds, like gold and dogs, but values, and we cannot understand a value unless we understand why it is important that we respect or seek out that value, unless we understand what is good about it." Dworkin (2001:255)

Para escolhermos entre as concepções rasas e dinâmicas, é preciso saber se ao nos comprometermos com alguma virtude, algo de ruim ocorreu, se algum valor foi perdido. Se considerarmos a igualdade independente das nossas escolhas entre trabalho e lazer, os que trabalham mais terão parte da sua renda transferida para os mais “preguiçosos”. Algo de ruim acontece ao preguiçoso se o Estado não faz essa transferência? Se não, então o conceito é do tipo raso. O mesmo pode ser feito com a liberdade. Se o Estado impedir alguém de me roubar, será prejudicial a mim? Não, então, da mesma forma, é um conceito raso de liberdade ${ }^{196}$.

A igualdade, definida dinamicamente, é satisfeita quando qualquer diferença nos recursos das pessoas for fruto dos custos diferentes das escolhas que as demais pessoas fizeram. Como já vimos, a igualdade de recursos é sensível às escolhas para que a responsabilidade individual tenha um papel importante nas questões de justiça. Ainda, a responsabilidade tem esse papel na teoria de Dworkin porque aspira a uma moralidade política que faça sentido para as pessoas, na sua ética pessoal ${ }^{197}$. Temos responsabilidade ética e moral pelas nossas escolhas, além de reforçar a idéia de que a política e a ética pessoal não estão isoladas. A liberdade, por sua vez, consiste em fazer o que desejamos com os recursos que foram distribuídos de forma justa.

\footnotetext{
${ }^{196}$ Dworkin lembra que Berlin também concorda que o Estado deve prevenir crimes, mas ainda assim considera que fere a liberdade.

${ }^{197}$ Ver mais em Dworkin (2002).
} 
A proposta de Dworkin evita o conflito entre a liberdade e a igualdade? Essa é a questão que procuramos responder.

\subsubsection{Qual o lugar da liberdade?}

Devemos analisar se a igualdade de recursos, se aceita como melhor alternativa para atender ao princípio abstrato de que todos devem ser tratados como iguais, entra em conflito com a liberdade, entendida como a liberdade negativa, liberdade de restrições legais.

Dworkin se propõe a defender uma parte da tese do liberalismo, de que as liberdades dos indivíduos nas questões mais pessoais, como escolhas sexuais, religião entre outras, não devem ser violadas. Ele vai refutar apenas aquelas teses do liberalismo que abrem mão da igualdade em nome de outras liberdades. Essa é a crítica ao liberalismo com base na neutralidade que vimos anteriormente. O que será apresentado aqui são as concepções de liberdade e igualdade que fazem parte do liberalismo baseado na igualdade.

A preocupação de Dworkin com a idéia de Berlin, de que os conflitos morais envolvem algumas vezes o embate de incomensuráveis, é que se torne o mote para que não façamos nada, sendo que uma distribuição de riqueza é algo necessário e urgente $^{198}$. Supor um conflito entre a liberdade e a igualdade e que são valores incomensuráveis, ${ }^{199}$ é supor que não há uma forma racional de fazermos uma escolha. Se começarmos a tratar esses conceitos propriamente, veremos que não existe conflito.

\footnotetext{
${ }^{198}$ Ver Crowder (2003).

${ }^{199}$ Williams em “The Legacy of Isaiah Berlin”, Mark Lilla, Ronald D. Dworkin, Robert B. Silvers (org.), 2001 afirma que a incomensurabilidade não levaria, necessariamente, a uma paralisia no processo de decisão. Ele quer apontar que este processo tem custos, ressaltando o pluralismo de Berlin. Os ganhos não serão sem custos.
} 
Se a igualdade de recursos é escolhida como a melhor versão para uma igualdade distributiva, então a liberdade não entra em conflito com ela, mas é parte constitutiva desse ideal. A liberdade, portanto, não é vista como um outro ideal independente, ou um valor isolado, como em outras teorias de igualdade que incorporam ou assumem ad hoc a importância da liberdade.

Nos conflitos políticos, a liberdade sempre parece ganhar da igualdade. Por que a liberdade tem esse privilégio? Se ela tem esse papel, precisamos saber responder pelo menos a razão de tal posição. Para o autor, se não temos uma resposta clara para explicar por que sempre a igualdade perde diante da liberdade, também não faz sentido pensar que a liberdade tenha um valor intrínseco, tal que justifique esse privilégio. E não podemos dizer que a liberdade é importante porque é.

A melhor resposta parece ser a seguinte: a liberdade é importante porque contribui para o valor da nossa vida. Não conseguimos identificar a importância da liberdade a não ser por esse motivo. A defesa da liberdade seguirá por um caminho diferente na teoria de Dworkin. A liberdade deverá ser defendida porque é necessária à igualdade. Se estamos aceitando a definição de igualdade como a igualdade de recursos, teremos que incorporar, na definição de igualdade, a liberdade. Para contrapor, pensemos na igualdade de bem-estar. Nesta, devemos buscar maximizar o bem-estar geral e, dada essa definição, nada nos garante que, para alcançar essa meta, algumas liberdades não sejam afetadas.

A igualdade de bem-estar simplesmente ignora, num primeiro momento, a liberdade. Provavelmente chegaríamos à conclusão de que algumas liberdades seriam fundamentais para o bem-estar, como a liberdade de expressão ou de associação política. Mas se o objetivo é alcançar o máximo de satisfação, não podemos afirmar que a liberdade não seria sacrificada para aumentar o bem-estar. Diferente da igualdade de bem-estar, a igualdade de recursos dá um lugar especial à liberdade: 
"Ela faz com que a distribuição igualitária não dependa exclusivamente dos resultados que possam ser avaliados de maneira direta, como preferência-satisfação, mas em um processo de decisões coordenadas no qual as pessoas que assumem responsabilidade por suas próprias aspirações e projetos, e que aceitam, como parte dessa responsabilidade, que pertencem a uma comunidade de igual consideração, possam identificar o verdadeiro preço de seus planos para as outras pessoas e assim, elaborar e reelaborar esses planos de modo que utilizem somente sua justa parcela dos recursos em princípio disponíveis para todos.” (VS: 160).

Ao contrário do que se possa pensar, o autor não quer transformar a liberdade num ideal de segunda ordem, ou preteri-lo no lugar da igualdade nos conflitos políticos. Mas então onde estaria a liberdade na igualdade de recursos? Ora, para que cada um dos indivíduos possa escolher seus planos de vida e proceder com as suas escolhas, é preciso um grau elevado de liberdade. Nossas convicções e aspirações devem ser autênticas e não impostas $^{200}$. O valor da liberdade está no seu papel na garantia da igualdade e não como algo instrumental ou secundário, ao contrário, ela está unida à igualdade. $\mathrm{O}$ argumento da igualdade de recursos para darmos valor à liberdade nos parece superior a simplesmente assumir que é importante per se.

Para Dworkin, as pessoas não acham realmente que a igualdade deve sempre ser preterida em relação à liberdade. Na verdade, estão discordando dos outros no que cada um acha que a igualdade requer. A rejeição é do conceito de igualdade que cada um assume como legítimo, por isso que a definição dos conceitos é tão relevante para essa discussão.

A liberdade e a igualdade admitem uma série de concepções, mas na disputa genuína entre essas duas virtudes, o governo deve agir para tornar a vida dos governados melhor e tratar a todos com igual consideração. Se a igualdade for preterida em nome da liberdade feriremos aquele princípio. As pessoas podem até negar o princípio

\footnotetext{
${ }^{200}$ A neutralidade do Estado em relação às nossas concepções de boa vida é essencial para que a igualdade de recursos cumpra seu papel. Como princípio básico do liberalismo, ela se mantém.
} 
abstrato, mas é difícil alguém aceitar que o Estado deve se preocupar mais com um grupo do que com os demais. ${ }^{201}$

Quais seriam as concepções mais adequadas para a liberdade e a igualdade? Para a liberdade, o autor considera que uma concepção aceitável é aquela que define certas liberdades como fundamentais e que não devem ser limitadas. Para fazê-lo, o governo deverá ter uma justificativa mais poderosa do que a necessária para outras decisões políticas. As liberdades essenciais seriam: liberdade de consciência, religião, expressão, liberdade de escolha para assuntos como opção sexual, carreira, tratamento médico. Estas últimas são de especial interesse do autor. Além disso, é em nome desses direitos, o de expressão, escolha de tratamento médico ou trabalho que as pessoas pedem proteção.

Sobre as concepções de igualdade, foi dito anteriormente que as pessoas não crêem que a igualdade tem tão pouca importância em relação à liberdade, mas que elas não a defendem porque a versão apresentada não é a genuína, ou seja, discordamos do que a igualdade requer. Se aceitarmos a igualdade de recursos como a melhor concepção de igualdade distributiva, será possível demonstrar que o conflito não existe. Nesta concepção, a liberdade é considerada um aspecto da igualdade, por isso teremos sua proteção sempre que a igualdade for alcançada. Como vimos na igualdade liberal, apresentada nos capítulos anteriores, o princípio mais abstrato, de que todos devem ser tratados com igual consideração e respeito, é o ponto de partida para Dworkin. Vai ficando mais claro que não há uma hierarquia lexicográfica de princípios de justiça como em Rawls, com a liberdade como prioridade, mas um ideal mais complexo que unifica a busca pela igualdade e liberdade. Também explica por que o autor não precisa utilizar o contrato como forma de garantir que os indivíduos escolham a liberdade e a igualdade como princípios de justiça.

\footnotetext{
${ }^{201}$ Estamos falando do princípio mais geral e legal de como o Estado deve tratar a todos como iguais, ou com igual consideração e respeito. Como vimos anteriormente, os deficientes serão tratados como iguais se tiverem em igual condição de se protegerem no mercado hipotético de seguros. Se tiverem formas de serem, mesmo que parcialmente, compensados pela sorte bruta.
} 
Para o problema filosófico de conflito entre a liberdade e a igualdade, Dworkin o aborda usando, novamente, ferramentas analíticas complexas. Ele vai elaborar duas estratégias de conciliação entre a liberdade e a distribuição ideal de recursos, e é a forma de conciliação entre elas que as diferenciará. A primeira estratégia é chamada de interesses e a segunda de constitutiva.

A estratégia de interesses nos apresenta uma explicação de como identificar os interesses das pessoas e como a distribuição ideal deve ser para atender esses interesses. Numa primeira etapa, essa estratégia não define a liberdade como parte desses interesses, mas, em seguida, define que sem ela, não podem ser propriamente alcançados. Como exemplos temos o utilitarismo e as teorias contratualistas. Primeiro, as pessoas definem os princípios de justiça, como se fossem seus interesses, dadas certas condições de escolha, e a distribuição ideal é aquela que atende aos princípios escolhidos. Supõe-se que entre os interesses estaria a liberdade.

A estratégia constitutiva tem uma abordagem completamente distinta ao incluir a liberdade na concepção de igualdade desde o início. Dworkin faz uma ressalva de que isso pode ser dogmático, mas ele afirma que é apenas uma primeira impressão que espera reverter e nos convencer de que essa é a melhor estratégia. A estratégia constitutiva é utilizada pelas teorias libertarianas como a de Nozick (1974), para quem a igualdade está garantida desde que as pessoas tenham liberdade de fazer o que desejarem com os recursos em sua posse, adquiridos de forma justa. O Estado deve garantir uma estrutura política que proteja as liberdades fundamentais. Nesse caso, não há conflito entre a liberdade e a igualdade. Obviamente, Dworkin não endossa a concepção de justiça de Nozick.

Para que não tenhamos conflito entre a liberdade e a igualdade, a igualdade de recursos deve adotar a estratégia constitutiva, visto que a estratégia de interesses causa problemas para esse princípio. Primeiramente, esta considera que as pessoas são diferentes nas suas convicções, personalidade e preferências e nas suas circunstâncias, como nos recursos, talentos e capacidades. 
A igualdade de recursos quer igualar as pessoas nas suas circunstâncias. Nesse caso, se usássemos a estratégia de interesses, teríamos que a liberdade pertenceria às circunstâncias das pessoas e não a sua personalidade. Isto posto, a liberdade seria tratada como um recurso como outro qualquer e seria, portanto, leiloado. Assim, teríamos que as pessoas escolheriam no leilão as liberdades que desejariam, mas cada uma vai escolher um tipo e uma quantidade que serão, com toda a certeza, distintos, já que estão atrelados às escolhas pessoais dos imigrantes. Seria impraticável termos alguns cidadãos com liberdade de expressão e outros não, por exemplo. A liberdade não poderia sobreviver desta forma e, por isso, não faria sentido usar a estratégia de interesses para conciliar a liberdade e a igualdade. Mais ainda, quando vamos para um leilão, já está implícito um sistema de liberdades/restrições, ou seja, não se pode ir ao leilão sem sabermos o que podemos fazer com os recursos adquiridos. Exemplo: se comprarmos um terreno para cultivar milho, devemos saber se podemos fazer isso, caso contrário podemos decidir dar um lance menor ou mesmo não adquirir esse terreno. Alteram-se completamente os custos de oportunidade. Portanto, antes de iniciarmos o leilão é preciso definir os parâmetros de um sistema de liberdades $e$ restrições.

Esse sistema deverá conter uma especificação das liberdades que são essenciais à equidade, em nosso caso, que melhor servir à igualdade de recursos e, uma vez definido esse sistema, o leiloeiro não poderá fazer leilões que modifiquem aqueles parâmetros.

Para fazermos uma defesa mais consistente da estratégia constitutiva, vamos usar a chamada versão da ponte, evitando assim a circularidade que, é dizer que a liberdade já está na definição da igualdade e, por essa razão, não entrariam em conflito. Dworkin propõe partirmos do princípio mais abstrato da igual consideração para chegarmos à igualdade de recursos, para que esta não seja a base do argumento.

A versão da ponte da estratégia constitutiva endossa o princípio de abstração, que diz que a distribuição ideal somente é alcançada se as pessoas forem legalmente livres 
para agirem como quiserem, salvo os casos de restrição de liberdade nos casos previstos como proteção da pessoa, da propriedade privada ou outros mecanismos importantes para o melhor funcionamento do mercado. O princípio de abstração quer nos mostrar qual o papel da liberdade para a garantia da igualdade.

Um aspecto fundamental do princípio de abstração é que ele não trata a liberdade como permissividade, mas como algo a ser limitado para a proteção da pessoa e da propriedade previstos nos sistemas legais modernos. Ele chama essas proteções de princípio de segurança.

A versão da ponte quer encontrar o verdadeiro custo de oportunidade de um conjunto de recursos, já que leilões com parâmetros diferentes geram resultados distintos, mas que, mesmo assim, podem passar pelo teste de inveja. O que buscamos é o verdadeiro custo de oportunidade. Precisamos encontrar os parâmetros do sistema de liberdades e restrições que contribuem para encontrarmos esse custo. Dworkin busca resolver o problema deixado na seção anterior, a igualdade de recursos como uma teoria indeterminada com múltiplos equilíbrios, daí a necessidade de construir uma teoria adequada para o verdadeiro custo de oportunidade.

A igualdade de recursos tem como métrica da equidade dos custos de oportunidade, ou seja, o valor de um bem adquirido por uma pessoa é o valor que outras pessoas renunciaram visto que deixaram de comprá-lo. Quando decidimos por um bem, estamos deixando de lado outros e o valor que pagamos pelo bem é chamado de custo de oportunidade. Então vamos selecionar as liberdades para chegarmos na melhor ponte entre o princípio igualitário abstrato e o teste de inveja, desde que elas nos apresentem o verdadeiro custo de oportunidade.

Lembrando que a igualdade de recursos exige que as pessoas tenham liberdade para colocar em prática, no mercado, suas preferências e convicções, quanto mais flexível for o leilão, mais opções serão oferecidas aos imigrantes e maior a probabilidade de atendermos às distintas concepções de boa vida. Isso significa dizer que os recursos 
devem ser postos à venda nas porções que os imigrantes desejarem. O limite para a divisibilidade é a capacidade do recurso ser utilizado. Se se vendessem apenas terrenos para plantar uma horta, aquele que quisesse fazer um campo de futebol seria prejudicado. Ou seja, precisamos que o leilão tenha flexibilidade suficiente para a adaptação aos planos de vida dos imigrantes.

O princípio de abstração tem um papel importante na definição de como os lotes de recursos serão oferecidos no leilão, além de apresentar o lugar da liberdade na igualdade de recursos. Como já foi dito, os limites a essa liberdade são definidos pelo princípio de segurança.

Uma questão importante que surge na discussão do sistema de liberdades e restrições, é como Dworkin analisa um pressuposto básico do liberalismo, a neutralidade do Estado em relação aos planos de vida das pessoas. Veremos que o conceito é diferente de outras teorias liberais de justiça.

Sabemos que quando se define um sistema de liberdades e restrições, estamos alterando os custos de oportunidade. Mas, dado o princípio de abstração, precisamos definir esse conjunto de liberdades que afetará as escolhas de cada um. Algumas formas de vida serão mais fáceis e outras mais difíceis de serem contempladas. Portanto, não há, na igualdade de recursos, essa neutralidade que vemos na teoria de justiça rawlsiana em relação a todas as concepções de boa vida. A neutralidade na igualdade de recursos tem outro sentido:

“(...) pretende que os recursos que as pessoas têm à disposição, com os quais realizarão planos, projeto ou modos de vida, sejam definidos pelos custos de terem esses e não outros, e não por qualquer juízo coletivo sobre a importância comparativa das pessoas ou o valor comparativo dos projetos ou das moralidades pessoais.” (VS: 209).

Portanto, a igualdade de recursos não endossa, no sistema de liberdades e restrições, quaisquer restrições baseadas na moralidade pessoal ou religiosa. É um argumento radical de Dworkin, visto que parece dizer que alguns planos de vida não serão possíveis, sejam pelas restrições legais do princípio de segurança, ou pelos custos de 
oportunidade. Em outras palavras, os planos de vida possíveis serão aqueles que respeitam a igualdade de recursos. A neutralidade está na importância dada às convicções de todas as pessoas de forma que continuemos a garantir a obediência à igual consideração e respeito. Ninguém deverá ter vantagem em relação ao outro na busca pela realização de suas preferências.

“A neutralidade nesse sentido não garante nenhum tipo de vida que
alguém possa querer que lhe seja disponível. Alguém que queira uma
vida de connoisseur imperial, reunindo enormes coleções de obras-
primas em um depósito particular, descobrirá que é impossível na
igualdade de recursos: não poderá pagar os custos de oportunidades
desse modo de vida, pois eles serão julgados em um leilão em que
todos tenham os mesmos recursos para os lances, mesmo que ele
sacrifique todo o resto. A igualdade de recursos tem essa
conseqüência, não porque deixa de ser neutra com relação ao
connoisseur, mas em virtude de ser neutra entre ele e os outros que
também querem estudar e desfrutar das obras de arte.” (VS: 209).

Esse sentido da neutralidade da igualdade de recursos amplia seu escopo porque inclui, não apenas as nossas preferências estampadas em nossos planos de vida, mas as circunstâncias que encontramos para realizá-los. É justamente essas circunstâncias que a igualdade de recursos busca igualar, sempre baseada no princípio igualitário abstrato de igual consideração.

Um dos aspectos fundamentais para a realização completa de nosso plano de vida é que tenhamos a formação de nossas preferências de forma autêntica, ou seja sem serem determinadas por outrem. Para isso, os indivíduos dessa sociedade, sob a igualdade de recursos, deverão ter acesso às atividades que permitam moldar a sua personalidade, em planos de vida, ou os modificar, se assim desejarem. Entre as liberdades que o princípio de abstração deve considerar como fundamentais estão justamente as que se relacionam com a autenticidade das preferências. Seriam elas: a liberdade de expressão com acesso à ampla informação, a religiosa, de associação e também de não-expressão (liberdade contra a vigilância). O leilão estará comprometido se a autenticidade não for garantida, ou seja, se essas liberdades sofrerem restrições, a não ser em casos extremos como a proteção da vida. 
Podemos dizer, enfim, que o alicerce da construção teórica de Dworkin para um novo liberalismo e uma nova teoria de justiça distributiva parte da idéia de igual consideração e respeito. Este princípio abstrato implica dois direitos, um mais amplo, que é ser tratado como igual e, outro mais restritivo, que é tratar a todos igualmente. O direito a ser tratado como igual, define que nenhum indivíduo poderá ter vantagens ou poderá se apropriar de um quinhão de recursos que não seja igualitário. Esse mesmo indivíduo terá a liberdade de buscar o seu plano de vida cujo valor estará associado ao seu exercício de viver de forma justa. O modelo do desafio irá medir o valor de uma vida de acordo com os desafios que se apresentam, sem cair na armadilha de que todos devamos ser heróis ou grandes artistas. O valor das nossas ações está relacionado com as circunstâncias, contexto, tempo e lugar e não a um fim objetivo transcendente. A cultura, o estado e a comunidade fazem parte desse contexto no qual medimos o valor da vida. O liberalismo baseado na igualdade é uma teoria moral contínua, na qual não há uma separação das concepções de boa vida e as escolhas políticas. O véu de ignorância é mais fino, a sociedade assume que os recursos devem ser distribuídos de forma igualitária, e que o Estado deverá zelar pela condução das relações econômicas a fim de coibir ações que firam a liberdade e a igualdade. A comunidade liberal de Dworkin é, portanto, fundamental para que se alcance o ideal da igualdade. 


\section{Capítulo 4 \\ Ronald Dworkin e John Rawls: A Prática e a Razão Pública ${ }^{202}$}

John Rawls e Ronald Dworkin são liberais igualitários, suas teorias de justiça se preocupam com a igualdade, liberdade, com os direitos individuais e com a tolerância para que os cidadãos busquem suas concepções de bem. O Estado não interfere nas decisões pessoais de cada indivíduo, apenas regula as instituições responsáveis por salvaguardar aqueles direitos. Ambos, segundo Dworkin, partem do direito abstrato de que todos devem ser tratados com igual consideração. A igualdade e a liberdade são virtudes políticas fundamentais para uma sociedade justa.

Numa primeira análise, a diferença parece estar na melhor interpretação para o conceito de igualdade. Para Rawls, devemos buscar a igual distribuição de bens primários, regida pelos dois princípios de justiça, e para Dworkin temos uma métrica distinta, a igualdade de recursos, cuja distribuição se dá por um leilão hipotético estabelecendo os custos de oportunidade de cada escolha. No entanto, Rawls recupera a tradição contratualista, e Dworkin coloca o desafio de não utilizar uma teoria desse tipo, vista como “arquimediana”, e endossar a continuidade entre ética e moralidade.

Da TJ, Rawls evolui para uma preocupação distinta em LP, o da estabilidade com da concepção de justiça, dado que o pluralismo moral é uma realidade e produto de uma sociedade democrática. Ele passa a chamar a sua teoria de concepção política de justiça, o liberalismo político. Dworkin oferece um liberalismo que chamo de abrangente e engajado. Engajado porque ele quer buscar um patamar comum, um common ground para o debate público e para recuperar o valor da democracia. Isso é particularmente importante na sua última obra publicada, até o momento em que esta tese foi escrita, “Is Democracy Posible Here?", onde ele defende como common ground os dois princípios de dignidade: o princípio do valor intrínseco e o princípio da

${ }^{202}$ Para as obras de Rawls, Uma Teoria da Justiça (TJ) e Liberalismo Político (LP). 
responsabilidade especial. O primeiro é uma representação abstrata da igualdade e o segundo da liberdade. Aqui poderíamos novamente fazer uma comparação com os dois princípios da justiça como equidade. Em Rawls há a hierarquia lexical entre os princípios, no caso da liberdade sobre a igualdade (esta última expressa no princípio de diferença). Com a razão pública, Rawls busca um patamar comum para tratar do pluralismo de uma democracia deliberativa, mas neste caso estamos num ambiente que restringe a participação das doutrinas abrangentes. A razão pública tem como conteúdo apenas convicções políticas. Na discussão do patamar comum, em Dworkin, ele quer salvar a democracia, salvar não do pluralismo, mas do fundamentalismo religioso e da divisão política profunda que tem ocorrido na sociedade americana. As questões são aplicadas àquela sociedade, mas são também temas universais.

Estamos explorando questões menos discutidas na literatura da teoria de justiça, assim como procuramos “juntar as pontas” da obra de Dworkin. Ele se opõe aos arquimedianos, propõe uma nova forma de pensar os conceitos normativos, garantindo uma continuidade entre a ética e a moralidade. O resultado é um liberalismo abrangente baseado na igualdade, com concepções de igualdade e liberdade que não entram em conflito, mas fazem parte de um único ideal político. Propõe-nos uma nova concepção de comunidade, a comunidade liberal, que diria que é sua definição moral de comunidade, na qual os indivíduos estão integrados, já que se importam com os destinos dos demais. Sua concepção "legal” de comunidade ele nos apresenta em sua teoria do direito.

Diante desse cenário, temos um liberal muito mais próximo dos comunitaristas, ao apresentar a comunidade como fonte de legitimidade para a aplicação dos princípios de justiça e de valor moral para os planos de vida de cada um de seus cidadãos. A tolerância liberal é garantida pela legitimidade das decisões das autoridades, que devem tratar a todos com igual consideração e respeito.

Como afirma Vita (2007), uma forma de lidar com o pluralismo é reduzir o conjunto de questões para as quais esperamos chegar a um acordo razoável. Quanto a isso, creio 
que Rawls e Dworkin estão de acordo. Evidentemente, os objetivos pessoais estão fora de uma teoria de justiça, já que cada indivíduo irá escolher seu plano de vida de acordo com sua concepção de bem. Para Rawls, a imparcialidade só entra para solucionar os conflitos nos "fundamentos constitucionais" e nas “questões de justiça básica”. Somente assim teríamos o endosso dos princípios de justiça, ou na linguagem de Vita (2007), chegaríamos a um acordo razoável. Dworkin não questiona o “espaço” de interferência do Estado, mas os instrumentos que utilizaremos a fim de chegarmos a um patamar comum para a resolução dos conflitos. Rawls quer se valer apenas das concepções políticas, enquanto Dworkin, inclui também a ética, por isso o liberalismo abrangente.

Neste capítulo final nosso objetivo é analisar a razão pública, e como Rawls nos apresenta um liberalismo, digamos mais estreito, o liberalismo político, que tem como objetivo a estabilidade da justiça como equidade, a concepção política de justiça. Nosso foco principal está na formulação da razão pública ${ }^{203}$ como instrumento garantidor da legitimidade, na forma de debate proposto por Rawls em contraposição ao common ground de Dworkin, baseado nos princípios de dignidade. Vamos apresentar de forma sucinta as características e conceitos principais do liberalismo político para em seguida discutirmos mais pormenorizadamente o papel da razão pública.

Apresentamos nos capítulos anteriores, de forma sistemática, o modelo de interpretação de Dworkin como alternativa às teorias arquimedianas de justificação moral. Em seguida, discutimos as suas interpretações sobre justiça, igualdade, liberdade e comunidade.

Nesta seção, estamos preocupados em tratar por que a separação do político das doutrinas abrangentes é fundamental para o liberalismo político de Rawls. Isso se

\footnotetext{
${ }^{203}$ Estamos considerando que nosso leitor conhece a teoria da justiça de Rawls, portanto não vamos apresentar toda a estrutura da teoria, especificar conceitos, a não ser aqueles essenciais para esta discussão.
} 
verifica não apenas na definição dos princípios de justiça, mas no que o autor define como razão pública, que deixaria de lado as doutrinas abrangentes para considerar apenas os valores políticos. Essa versão mais restrita de razão pública foi substituída por uma visão mais ampla que ele apresenta em "The Idea of Public Reason Revisited”. Essa mudança de Rawls parece atender a críticas à “camisa de força” então imposta. A busca do common ground, para ele, passa pela separação entre ética e moralidade que para Dworkin não faz sentido. Ou ainda, como afirma O’Neill (1997), a versão de liberalismo de Rawls é menos ambiciosa em dois sentidos, o primeiro porque as questões normativas substantivas ficam confinadas ao domínio do político, e o segundo porque dispensa fundamentos metafísicos e morais, sendo a concepção liberal de justiça política e não metafísica ${ }^{204}$.

"Since the publication of Political Liberalism, the term 'political liberalism ' has increasingly been used to indicate this quite specific version of liberalism, whose normative claims are merely political, and which purports not to draw on "comprehensive moral doctrines", or on unsustainable metaphysical claims”. O’Neill (1997:411).

Essa versão de liberalismo, bem específica e menos ambiciosa, é sustentada em grande parte pela idéia de razão pública. Daí nosso interesse voltar-se para essa questão. Mais do que isso, como afirma o próprio autor, “o conteúdo dessa razão [pública] - a forma como ela é entendida pelos cidadãos e como eles interpretam sua relação política - é parte da própria democracia”. ${ }^{205}$ A própria definição de democracia passa pelo entendimento do que é a razão pública.

Antes de iniciarmos a discussão, é importante ressaltar estamos tratando de dois autores, Dworkin e Rawls que não devem ser vistos como opositores, mas como competidores. Dworkin foi muito influenciado por Rawls e ambos defendem o liberalismo e a democracia. São interpretações diferentes de um mesmo tema que pode ser melhor explicitadas quando colocadas frente a frente.

\footnotetext{
${ }^{204}$ O’Neill (1997:411). Rawls apresenta um texto que toma a concepção liberal como política e não metafísica. Ver Rawls (1985).

${ }^{205}$ Tradução livre de trecho em Rawls (1997: 765).
} 
Como bem afirma Ripstein (2007), a proposta dworkiana é mais ambiciosa em duas frentes. Primeiro, Rawls confina, nos seus trabalhos posteriores, o equilíbrio reflexivo no campo político. Mas para Dworkin, uma interpretação cuidadosa dos argumentos da prática moral revela uma continuidade entre a moralidade pessoal ou ética e a moralidade pública. Segundo, o equilíbrio reflexivo deve ser tomado como um tipo de interpretação mais geral, que tenha em mira como os nossos julgamentos sobre vários domínios do valor podem estar $\operatorname{corretos}^{206}$. Por isso, a justificação moral, como apresentamos no capítulo 1, é um caso especial do exercício interpretativo.

Dworkin dá continuidade à tradição liberal, mas sua origem, como vimos, está no estudo do direito, no entanto de forma menos idealizada e mais pragmática. A sua defesa do liberalismo é a defesa da própria democracia. Ele parte dela para garantir a estabilidade de uma concepção de justiça, seu principal temor é com a estabilidade da própria democracia. Isso fica mais evidente nos trabalhos mais recentes nos quais aplica a concepção abrangente de liberalismo para engendrar um debate sério e genuíno sobre as questões que dividem uma sociedade democrática. Não é possível questionar que o pluralismo faz parte do exercício da liberdade de expressão e política, mas essa mesma liberdade está sendo ameaçada. De forma semelhante a Rawls, Dworkin nos alerta para esta estabilidade. Em Is Democracy Possible Here? Principles for a New Political Debate, ele afirma que os Estados Unidos passam por um período político perigoso e que os tópicos tratados são de importância geral. O debate partiria de princípios pessoais e de moralidade política profundos que todos respeitam. As sociedades democráticas avançadas ou seriamente comprometidas com o desenvolvimento:

“(...) must find ways to choose among rival convictions about the nature and force of human rights, the role of religion, in politics, the distribution of the community's economic wealth, and the character and forms of the politics through which those decisions are made. (...) I concentrate rather on issues on which people's apparent self-interest and personal commitments appear antagonistic, and the question arises

${ }^{206}$ Ripstein (2007:8) 
whether they share even deeper interests and commitments that can shape an argument, not just fuel a war.” Dworkin (2006a: xi-xii)

Por isso, a agenda dele é buscar um patamar comum para o debate e que isso é possível, conforme apresentamos no capítulo um. Um liberalismo com uma agenda positiva e que nos faça tratar as controvérsias de forma mais filosófica. A essa proposta, vamos contrapor o liberalismo político de Rawls a ser apresentado a seguir. Para Rawls, não podemos chegar a nenhum acordo se nos basearmos numa doutrina abrangente, por isso sugere uma razão pública cujo conteúdo seja apenas de valores morais. Como afirma Larmore (2003) ${ }^{207}$, Rawls também busca esse patamar comum, mas apenas de outra forma e separando a ética da moralidade.

A mudança mais importante apresentada em LP é a independência da concepção política de justiça em relação às doutrinas filosóficas, morais e religiosas abrangentes, mas uma concepção auto-sustentada (freestanding). Esse livro trata de um tema diferente da TJ: para Dreben (1999) o tema deste é a justiça, enquanto que em LP é a legitimidade, tema pouco tratado pela tradição liberal. Freeman (2007) compartilha dessa afirmativa, mas reforça que o LP pode ser interpretado de forma independente da TJ justamente porque trata do tema da legitimidade, como o exercício do poder político na sociedade liberal, que nem aparece na obra anterior. Quando tratamos da natureza da justiça, não temos apenas uma teoria da justiça, mas é preciso dizer por que essa teoria é estável.

No construtivismo kantiano, os princípios de justiça devem ser vistos como princípios de razão prática e devem ser construídos, não estão lá disponíveis para serem descobertos, ou designados por Deus. O construtivismo também se opõe ao ceticismo moral, já que podemos encontrar a verdade para questões morais. Trata-se de encontrarmos os princípios resultantes de um procedimento puro de justiça no seu maior nível.

${ }^{207}$ In Freeman (2003:368). 
A posição original representa os agentes morais que possuem os dois poderes morais e os considera como livres e iguais. Essas pessoas são racionais e razoáveis, distinção crucial para Rawls. Estamos buscando um acordo razoável e não a verdade, ou o que é correto, senão nunca chegaremos a um acordo. Debren (1999) resume por que a distinção é importante:

“(...) if you wish to have a coherent conception of constitutional liberal democracy, then one the most basic political questions concerning that society the notion of truth or the notion cof right cannot the governing notion. It must be replaced by a notion of reasonableness, where reasonableness does not entail truth or right. Otherwise you could not possibly hope for agreement between people who hold conflicting comprehensive doctrines; conflicting comprehensive doctrines will have different concepts of truth connected to them." Dreben (1999: 324).

As pessoas são racionais porque podem conceber um plano de vida baseadas nas suas doutrinas abrangentes, e são razoáveis porque tem senso de justiça, ou seja, podem entender e aplicar os princípios de justiça.

Em Rawls, assim como em Dworkin, as pessoas são livres para escolher a sua concepção de bem, devem ser responsáveis pelas suas escolhas e podem exigir seus direitos perante às instituições da estrutura básica da sociedade ${ }^{208}$. Dworkin afirma que parte de um “direito natural” de que todos devem ser tratados com igual consideração e respeito e dos dois princípios de dignidade.

Na posição original, modela-se uma concepção de pessoa e de sociedade para que tenhamos esse procedimento de construção dos princípios de justiça. Pessoas racionais, razoáveis, livres e iguais sem motivações pessoais quando escolhem os princípios de justiça. Para isso, devemos instituir o "véu de ignorância” a fim de

\footnotetext{
${ }^{208}$ Estamos nos referindo a idéia da autonomia para viver a própria vida que é diferente de dizer que a concepção de bem é a prática da autonomia individual. Nesta dá-se muita ênfase na capacidade de cada indivíduo de escolher os próprios fins, desvalorizando-os em detrimento da capacidade de escolhê-los. Ver Vita (2007: 275-76). Interessante é que Dworkin afirma que o importante é o desafio de viver a vida, e não os seus fins, ou o impacto que podemos ter no mundo.
} 
garantir que os interesses sejam os mais elevados. Portanto, na estrutura da posição original excluem-se motivações pessoais, mas eles sabem que possuem uma concepção de bem e os poderes morais. As partes, portanto, se situam simetricamente na posição original.

A idéia da razão pública, tão importante no LP pode ser derivada do papel social ou prático da concepção de justiça que aparece pela primeira vez em "Kantian Construtivism and Moral Theory” (KC). Ela tem seu papel social quando oferece uma justificativa para aceitação da concepção de justiça para todos os membros da sociedade, mesmo considerando as profundas diferenças entre as concepções de bem. A essas diferenças Rawls chama de pluralismo razoável. A justificativa deve se apoiar em parte das crenças compartilhadas, as quais seriam apenas aquelas do campo da política, deixando de fora as doutrinas abrangentes. Por isso Freeman (2007) afirma que as sementes para a concepção de razão pública já existiam em KC e nas revisões a serem feitas no próprio construtivismo kantiano. Para os propósitos deste trabalho, nos interessa sua construção de razão pública e por que Rawls passa a chamar essa visão de construtivismo político.

Rawls chega à conclusão de que a idéia de sociedade bem-ordenada é irrealista porque não podemos assentar uma concepção de justiça numa doutrina abrangente, dado o pluralismo razoável. As pessoas podem até aceitar os princípios de justiça, mas dificilmente compartilharão as doutrinas morais, religiosas e filosóficas.

\subsection{O Liberalismo Político}

Em LP, Rawls vai questionar a idéia de sociedade bem-ordenada apresentada na TJ. Uma das premissas é que os cidadãos endossam a "justiça como equidade” com base numa doutrina filosófica abrangente. Os dois princípios de justiça escolhidos na posição original estão fundamentados nessa doutrina, mas o que temos é uma 
pluralidade de doutrinas abrangentes e razoáveis, que ele chama de pluralismo razoável. Por isso, não faz sentido falar numa sociedade bem-ordenada. O autor vai reformular a justiça como equidade que passa a ser uma concepção política de justiça, o liberalismo político. Para garantir que ela não seja mais uma concepção abrangente, que seja aceita voluntariamente e tenha legitimidade, mesmo diante do pluralismo razoável, deveremos tratá-la como auto-suficiente em relação às doutrinas abrangentes. Isso significa, nas palavras de Dworkin, a separação entre ética e moralidade.

Como coloca Anderson (2000), ${ }^{209}$ o objetivo da concepção política de justiça é uma doutrina de termos justos de cooperação para regular as instituições desenhadas para “desviar” das controvérsias filosóficas, éticas e religiosas. Uma concepção política de justiça é bem sucedida se atrair um consenso sobreposto das visões razoáveis abrangentes dos membros da sociedade. A concepção política de justiça faz emergir ideais latentes na cultura política e trata desses ideais de forma que possam ser aceitos por todos após reflexão.

A forma como os princípios são selecionados e a estrutura da concepção de justiça são, em essência, os mesmos. O que muda é o foco que Rawls dá nessa segunda obra, qual seja, garantir a estabilidade da concepção política de justiça, isolando-a de quaisquer doutrinas abrangentes. Será sobre essa mudança que se encontra a nossa (e a de Dworkin) maior crítica, a separação que ele faz entre ética e moralidade, tanto na definição dos princípios de justiça, com o uso do véu de ignorância, quanto no conteúdo da razão pública, que deve conter apenas o político.

A posição original continua exercendo um papel fundamental na definição dos princípios, mas, uma vez escolhidos, devem ser aceitos. Nela as partes, que estão sob o véu de ignorância, estão posicionadas de forma equânime, simétrica, já que há um desconhecimento em relação à classe social, gênero, gostos etc, por isso Rawls chama sua teoria de “justiça como equidade”. É uma situação hipotética que segue a tradição

${ }^{209}$ Anderson, R. , in Davion \&Wolf (2000:245). 
contratualista de Locke, Rousseau e Kant. A posição original é, por assim dizer, equivalente ao estado de natureza da teoria do contrato social. Como bem define Rawls, a posição original é o status quo apropriado para a escolha dos princípios de justiça. Os princípios escolhidos na posição original são aceitos por pessoas livres e iguais, e são aplicados somente à estrutura básica da sociedade.

"Idealmente, justificar uma teoria da justiça para alguém consiste em oferecer-lhe uma prova de seus princípios com premissas que ambos aceitamos, tendo esses princípios, por sua vez, conseqüências que estão de acordo com nossos juízos ponderados.” Rawls (2008:716).

Os dois princípios de justiça estão em ordem lexical, portanto, as liberdades devem ser garantidas antes de aplicar o princípio de diferença, como na TJ.

A posição original nos dá o que chamamos de ponto arquimediano, conforme explicitado no capítulo 1. No §41 da TJ, Rawls explicita sua preocupação em mostrar que a perspectiva contratualista define um ponto de vista arquimediano. A questão que se coloca é que a escolha das instituições que regularão a vida das pessoas deve se basear em alguma concepção de bem. O sistema social exerce essa influência sobre o que as pessoas querem ser e o tipo de pessoas que são. Então, diante disso, pode parecer que a teoria da justiça se baseia nos objetivos de indivíduos existentes e os princípios seriam escolhidos com base nesses objetivos. Mas a posição original e sua interpretação kantiana apenas fazem suposições genéricas sobre os objetivos das partes. Definir que as partes desejam os bens primários não é vincular a escolha dos princípios de justiça a um determinado padrão de interesse da pessoa. O que temos é uma teoria rasa do bem:

“A teoria de justiça pressupõe, de fato, uma teoria do bem, mas dentro de limites amplos isso não prejulga a escolha do tipo de pessoa que os homens querem ser.” Rawls (2008:324).

No LP, as partes na posição original têm "o mais alto interesse" em exercer e desenvolver seus poderes morais, quais sejam a capacidade de ter senso de justiça e a 
capacidade de ter uma concepção do bem. É isso que torna as pessoas iguais. Somente com esses poderes morais desenvolvidos, elas serão efetivamente livres e iguais. Desse mais alto interesse derivamos a lista dos bens primários sociais (direitos e liberdades em geral, oportunidades, riqueza, e o auto-respeito). Sem os bens primários, os dois poderes morais não poderão ser exercidos e desenvolvidos. Daqui derivamos o interesse das partes no contrato de Rawls:

"For Rawls the fundamental interests that motivate the parties to his social contract, and which explain their desire to obtain maximal or at least adequate primary goods, are the two moral powers and their determinate conception of their good." Freeman (2007:298).

Freeman (2007) complementa afirmando que esse interesse não é pessoal, mas baseado numa concepção ainda mais rasa de bem. Os interesses, portanto, não são objetivos finais dos agentes, mas regulam a forma como vão conduzir suas ações em busca de seu plano de vida.

A posição original, para Rawls, tem a clareza necessária na forma das condições gerais e no véu de ignorância, permitindo que a justiça requeira de nós mais do que a simples preocupação com os nossos próprios interesses. A neutralidade em relação às concepções de bem está vinculada à forma da posição original. Partimos, para a definição dos princípios de justiça, de uma base equitativa, sob o véu de ignorância, para impedir que as contingências influenciem aquela escolha. Dessa maneira, a posição original faz parte do método arquimediano de Rawls, separando a ética da moralidade. É com esse procedimento que podemos encontrar um ponto focal para um consenso sobreposto:

"Isso sugere que deixemos de lado a forma pela qual as doutrinas abrangentes das pessoas se relacionam com o conteúdo da concepção política de justiça, e consideramos esse conteúdo como resultante de várias idéias fundamentais retiradas da cultura da política pública de uma sociedade democrática. Uma forma de expressar isso é colocar as doutrinas abrangentes das pessoas por trás de um véu de ignorância. Isso nos possibilita encontrar uma concepção política de justiça que 
pode constituir o ponto focal de um consenso sobreposto e, desse modo, servir de base pública de justificação numa sociedade marcada pelo fato do pluralismo razoável.” Rawls (2000: 68).

O próprio autor admite que uma das formas de preservar a clareza da posição original é evitar atribuir às partes qualquer motivação ética (pessoal). No entanto, Rawls percebe que a idéia de uma sociedade bem-ordenada é irrealista e que os princípios de justiça não podem se basear numa doutrina abrangente ${ }^{210}$. O problema do liberalismo político é:

“(...) compreender como é possível existir, ao longo do tempo, uma sociedade estável e justa de cidadãos livres e iguais profundamente divididos por doutrinas religiosas, filosóficas e morais razoáveis, embora incompatíveis. Em outras palavras: como é possível que doutrinas abrangentes profundamente opostas, embora razoáveis, possam conviver e que todas endossem a concepção política de um regime constitucional?” Rawls (2000:25-6).

A posição original é vista como um caso de justiça procedimental pura, na qual as partes não se vêem obrigadas a aplicar nenhum princípio de direito e justiça determinado previamente ou limitadas por ele.

"Em outras palavras, não reconhecem nenhuma opinião externa a seu próprio ponto de vista, enquanto representantes racionais, pela qual sejam limitados por princípios anteriores e independentes de justiça. Isso leva à idéia de que, quando os cidadãos estão equitativamente situados uns em relação aos outros, cabe a eles especificar os termos equitativos de cooperação social, à luz do que cada um considera seu benefício pessoal, ou bem.” Rawls (2000: 118).

O objetivo das partes é chegar a um acordo sobre os princípios de justiça permitindo que os indivíduos possam realizar suas concepções de bem, além de desenvolver suas capacidades morais.

\footnotetext{
${ }^{210}$ As doutrinas abrangentes razoáveis têm três características essenciais. A primeira é que dizem respeito aos principais aspectos religiosos, filosóficos e morais da vida. Como elas organizam esses aspectos é um exercício de razão prática. As doutrinas não são fixas, mas fazem parte de uma tradição de pensamento e doutrina. O próprio autor considera que a sua definição é vaga. Ver Rawls (2000:103).
} 
Os princípios de justiça vão nos dar os termos equitativos da cooperação entre os cidadãos e são aplicados à estrutura básica da sociedade ${ }^{211}$. Após essa etapa, a questão é saber como a sociedade bem-ordenada vai estabelecer e manter a estabilidade dessa concepção de justiça. Como a unidade não pode ser garantida por uma doutrina abrangente e razoável, nem ser o conteúdo do que Rawls chama de razão pública sobre questões políticas fundamentais, ele introduz a idéia de consenso sobreposto. Neste consenso, as doutrinas abrangentes razoáveis endossam a concepção política de justiça. Portanto, em relação à TJ, a unidade não se baseia em uma doutrina, mas num consenso de doutrinas abrangentes. Ele pressupõe, portanto, que a concepção endossada não conflita fortemente com as convicções pessoais.

Para Rawls, ao aceitarmos o pluralismo razoável, presumimos um consenso sobreposto ideal, que todo indivíduo endossa uma doutrina abrangente e uma concepção política focal, relacionadas de alguma forma. O que ele quer é separar os elementos da concepção política de justiça dos das doutrinas abrangentes em busca de uma neutralidade. O liberalismo deverá fazer uma distinção entre a razão pública e as razões não públicas, além disso, ser imparcial em relação às doutrinas abrangentes e razoáveis. A questão que se discute no liberalismo político é o da tolerância diante da pluralidade de concepções do bem.

"As lutas mais difíceis, pressupõe o liberalismo político, são reconhecidamente travadas em nome das coisas mais elevadas: da religião, das visões filosóficas de mundo e das diferentes concepções morais do bem. Pode parecer surpreendente que, com oposições tão profundas assim, a cooperação justa entre cidadãos livres e iguais seja possível.” Rawls (2000:46)

A concepção política de justiça deve ser compartilhada pelos cidadãos como base de um acordo político razoável, bem-informado e voluntário. Para isso, ela precisa ser independente de doutrinas filosóficas e religiosas conflitantes. Desta forma, o liberalismo político aplica o princípio da tolerância à filosofia. Percebemos que a

${ }^{211}$ Rawls (2000:179). 
separação da ética da moralidade é fundamental para que o liberalismo político seja auto-suficiente, estável e legítimo. A cooperação é guiada por regras e procedimentos publicamente reconhecidos e aceitos pelos indivíduos. Por isso,

“(...) é desejável renunciar às visões filosóficas e morais abrangentes que estamos habituados a usar para debater questões políticas fundamentais na vida pública. A razão pública - o debate dos cidadãos no espaço público sobre os fundamentos constitucionais e as questões básicas de justiça - agora é mais bem orientada por uma concepção política cujos princípios e valores todos os cidadãos possam endossar. Essa concepção política deve ser, por assim dizer, política e não metafísica." Rawls (2008:52-3)

É desta forma que o autor consegue apresentar o liberalismo político como autosustentável (free-standing) e se refere a ele como um módulo, separado das doutrinas abrangentes, mas que se "encaixa” nas mesmas. O seu conteúdo é expresso por idéias fundamentais implícitas na cultura política de uma sociedade democrática. Essa cultura de fundo é formada, por sua vez, pelas doutrinas abrangentes.

Vemos que a preocupação de Rawls é isolar a ética da moralidade para garantir a estabilidade da concepção política de justiça. Esta deve estar limitada ao "domínio do público”.

Essa separação entre o privado e o público também se reflete na forma como Rawls trata da identidade dos indivíduos, composta por duas partes. Temos uma identidade institucional e outra não-institucional ou moral, já que além de objetivos políticos teríamos outros objetivos. Nossa função é ajustar e reconciliar os dois aspectos da identidade. Em outras palavras, as visões globais dos cidadãos têm duas partes, a concepção de justiça publicamente reconhecida e outra é uma doutrina abrangente, à qual a doutrina política está ligada de alguma forma.

Em resumo, a estrutura básica da sociedade é regulada por uma concepção política de justiça, essa concepção é objeto de um consenso sobreposto entre doutrinas 
abrangentes e razoáveis e a discussão pública é conduzida nos termos da concepção política de justiça.

Retomemos dois outros conceitos importantes que compõem do cenário no liberalismo, as idéias de razoável e racional. O razoável, segundo Rawls, está ligado a agir moralmente, porque pessoas razoáveis levam em conta as conseqüências de suas ações sobre a felicidade dos outros ${ }^{212}$. Mais ainda, compõe a idéia de que a sociedade é um sistema de cooperação equitativa, e os termos equitativos devem ser razoáveis para receber o endosso. A cooperação equitativa está relacionada a outro conceito que é o de reciprocidade, que diz que todos envolvidos na cooperação que fazem a sua parte, respeitando as regras, devem beneficiar-se dela.

O racional é uma idéia distinta do razoável e aplica-se a um agente único e unificado, dotado das capacidades de julgamento e deliberação ao buscar realizar fins e interesses próprios. O racional aplica-se à forma como podemos alcançar nossos objetivos.

São duas idéias básicas, independentes e complementares na justiça como equidade. $\mathrm{Na}$ cooperação equitativa, essas idéias conectam-se com a capacidade de ter um senso de justiça e de ter uma concepção do bem. À primeira se associa a idéia de razoável, e à segunda, a idéia de racional.

\footnotetext{
"Agentes puramente razoáveis não teriam fins próprios que quisessem realizar por meio da cooperação equitativa; agentes puramente racionais carecem do senso de justiça e não conseguem reconhecer a validade independente das reivindicações de outros”. Rawls (2000: 96).
}

Podemos dizer que o razoável é público de uma forma que o racional não o é. É pelo razoável que entramos como iguais no mundo público dos outros. Colocamo-nos e reconhecemos os demais como iguais na esfera pública. Para Rawls, não temos uma sociedade razoável apenas de santos ou de egoístas. Rawls tenta corrigir a idéia de que

\footnotetext{
${ }^{212}$ Ver Rawls (2000:92), nota 1.
} 
a justiça como equidade seria parte de uma teoria da escolha racional. Não se busca derivar o razoável do racional, seria uma interpretação errada da posição original.

Outro aspecto importante do razoável é a disposição de reconhecer os limites do juízo e aceitar suas conseqüências para o uso da razão pública na condução do exercício legítimo do poder político num regime constitucional. As pessoas podem discordar no exercício de sua razoabilidade, o desacordo razoável. A isso acrescentamos que essa discordância entre pessoas razoáveis nos leva a uma análise das razões para as mesmas, ou como visão das fontes, ou limites do juízo.

Podemos discordar por conta de preconceitos, predisposições, interesses de grupo ou pessoais, mas estas seriam fontes de discordância não razoáveis. Considerar o limite do juízo é garantir a tolerância, já que, mesmo que os nossos juízos sejam razoáveis, não podemos garantir, nem obrigar que todos concordem com eles. Esse limite do juízo daria consistência para a razão pública.

A consequiência dos limites do juízo é que nem todas as pessoas razoáveis professam a mesma doutrina abrangente. Não é porque as outras pessoas não concordam com a nossa doutrina que podemos dizer que não são razoáveis. O pluralismo razoável faz parte de uma sociedade com instituições justas. As pessoas razoáveis aceitam os limites do juízo, por isso, endossam alguma forma de liberdade de consciência e autonomia de pensamento.

Nenhum cidadão tem o direito de empregar a coerção do Estado para impor as diretrizes de sua doutrina abrangente. Todos são igualmente representados no poder coletivo.

“(...) quando igualmente representados na posição original, nenhum representante dos cidadãos pode outorgar a qualquer outra pessoa, ou associação de pessoas, a autoridade política de fazer isso.” Rawls (2000:106) 
As características que atribuímos aos cidadãos, a disposição de propor e sujeitar-se a termos equitativos de cooperação, o reconhecimento dos limites do juízo, a aceitação apenas das doutrinas abrangentes razoáveis e o desejo de ser cidadãos completos, proporcionam a base para lhes atribuir uma psicologia moral razoável. Rawls nos apresenta uma psicologia moral baseada na concepção política de justiça como equidade. É uma concepção política de pessoa e um ideal de cidadania.

Precisamos entender como funciona e qual o conteúdo da razão pública a fim de evidenciarmos o quão importante é a separação entre ética e moralidade para Rawls.

\subsection{A Razão Pública}

Segundo Rawls, as pessoas divergem não apenas por desconhecimento ou preconceito, mas também devido aos "limites da razão" ou do julgamento, por isso a justiça como equidade, da forma como foi apresentada antes não garante a estabilidade. Então Rawls se afasta da tradição de Kant e de Mill de liberalismo abrangente para conceber o liberalismo político. Era preciso aplicar o princípio da tolerância à filosofia em si $^{213}$. O liberalismo político não é apenas um compromisso baseado num denominador comum, apesar das divergências, mas baseado em princípios que as pessoas têm razões para aceitar. Por isso, podemos dizer que Rawls também busca um patamar comum.

“(...) their reasons for embracing the principles must not spring simply from their different perspectives but must also draw upon a common point of view (grifo nosso). Only so, as we have seen, can these principles represent fair terms of cooperation that express mutual respect. The shared understanding of principles of justice must therefore be at once reasoned and neutral with regard to the comprehensive conceptions of the good on which citizens disagree." Larmore (2003: 380).

${ }^{213}$ Ver Larmore (2003: 379). 
Na conferência sobre a razão pública no LP, o autor afirma que todo agente razoável, único ou coletivo, possui uma forma de articular os seus planos e de definir uma forma de tomar as decisões. A forma de uma sociedade política fazer isso é sua razão.

Uma cidadania plenamente exercida deve passar pela razão pública, que é característica de um povo democrático. O objeto da razão é o bem público.

Segundo Rawls, devemos ser capazes de justificar uma forma limitada de liberalismo e somente no domínio do político esta poderá ser justificada para todos. Ou seja, visto que as concepções de bem são irreconciliáveis, era preciso encontrar uma alternativa seja aceita por todos. Em outras palavras, limitar-nos aos valores políticos e deixar de fora as doutrinas filosóficas, morais e religiosas abrangentes. Ou, como afirma Dreben (1999), se Rawls busca uma concepção coerente para a democracia liberal constitucional, não devemos tratar as questões políticas mais básicas sob uma noção de verdade ou de correção. Devemos substituí-la por uma noção de razoabilidade, que não inclui verdade ou correção. Se seguíssemos por aquele caminho, não poderíamos encontrar nenhum acordo entre pessoas com concepções de bem conflitantes.

"I propose that in public reason comprehensive doctrines of truth and right be replaced by an idea of the politically reasonable addressed to citizens as citizens." Rawls (1997:766).

A razão pública não é um valor como outro qualquer, é a relação política que os cidadãos estabelecem entre si, quando tratamos da nossa razão perante a razão dos demais, expondo um ponto em comum para estabelecer os termos da vida pública. Ela estabelece a forma como as instituições se relacionam com seus cidadãos e eles entre si. É a forma como a democracia efetivamente se realiza e inclui esse conceito de reciprocidade. A razão pública busca identificar princípios de cooperação por meio de 
um processo de justificação ${ }^{214}$. Embute um ideal de equidade e questões relacionadas com os termos justos de cooperação social, que pertencem à deliberação política.

Tem uma estrutura definida e não se aplica a uma "cultura de fundo"215, ou seja, a cultura da sociedade civil que inclui igrejas, universidades, associações. Ela não se aplica a todas as questões políticas, mas apenas aquelas no fórum político público. No discurso dos juízes, do governo e dos candidatos a cargo público.

A razão pública apresenta-se de três formas: 1) como razão de cidadãos livres e iguais, é a razão do público; 2) seu objeto é o bem público relacionado a questões de justiça, que são de dois tipos, constitucional e de justiça básica ${ }^{216}$; e 3) seu conteúdo e natureza são públicos, expressa por uma família de concepções políticas de justiça.

Para Rawls, idealmente, os cidadãos deveriam se comportar como legisladores ideais, repudiando aqueles que violam a razão pública. Assim, eles estariam fortalecendo a democracia e assumindo seu “dever de civilidade” em relação aos demais. Esse dever, assim como outros direitos e deveres políticos, é moral e não legal.

Quando os cidadãos participam de um debate sobre questões políticas fundamentais, vão recorrer a esta razão, cujo conteúdo é dado pelos princípios e valores das famílias das concepções políticas de justiça. Essas concepções devem possuir as seguintes condições $^{217}$ : ser aplicadas à estrutura básica da sociedade; devem ser apresentadas de forma independente de quaisquer doutrinas abrangentes; e podem ser tratadas a partir

\footnotetext{
${ }^{214}$ O’Neill (1997:416).

${ }^{215}$ A "background culture", "(...) includes, than, the culture of churches and associations of all kinds, and institutions of learning at all levels, especially universities and professional schools, scientific and other societies. In addition, the nonpublic political culture mediates between the public political culture and the background culture. This comprises media - properly so named - of all kinds: newspapers, reviews and magazines, TV and radio, and much else.” Rawls (1997:768), nota 13.

${ }^{216}$ A parte constitucional - constitutional essentials - diz respeito às liberdades e direitos políticos (constituição) e as questões de justiça básica, diz respeito à estrutura básica da sociedade, às questões de justiça social e econômica básicas e outras não tratadas por uma constituição.

${ }^{217}$ Ver Rawls (1997:776).
} 
da concepção de pessoas livres e iguais e da sociedade como um sistema justo de cooperação.

A principal diferença da definição da razão pública em relação ao que foi apresentado em LP é que em Rawls (1997), temos uma versão menos restritiva. Na versão revista Rawls admite que mesmo que o conteúdo da razão pública obedeça aos requisitos acima, quando do debate de questões políticas fundamentais, podemos introduzir nossa doutrina abrangente, cujos princípios e valores estão, eles próprios baseados numa razão pública.

"This requirement still allows us to introduce into political discussion at any time our comprehensive doctrine, religious or nonreligious, provided that, in due course, we give properly public reasons to support the principles and policies our comprehensive doctrine is said to support. I refer this requirement as the proviso, and consider it in detail below”. Rawls (1997: 776).

A justificativa de Rawls é que todo o debate público deve ocorrer sob uma concepção política de justiça, mas os valores políticos também incluem outros tipos de valores. Ele utiliza como exemplo o fato de que, sob a justiça, temos equidade de liberdades básicas, igualdade de oportunidade, etc. Considero que ele não é claro o suficiente nesse aspecto, mas posso afirmar que ele parece sugerir que os valores políticos, muitas vezes, não podem ser isolados de outros valores quando no debate de questões políticas fundamentais. Mais adiante, ele afirma que estamos preocupados apenas com as concepções políticas que são razoáveis para um regime democrático constitucional, ou seja, concepções políticas liberais razoáveis. As concepções políticas da razão pública devem responder a todas as questões constitucionais e de justiça básica ${ }^{218}$.

\footnotetext{
${ }^{218}$ Vita (2008) questiona as interpretações sobre a razão pública que a consideram muito restritiva. Se a razão pública pertencer ao que ele chama de argumentação moral, nada seria excluído do debate público, visto que isso não está em seu poder. Na deliberação política, diferente da argumentação moral, fatalmente nos defrontaremos com as doutrinas abrangentes. O próprio autor afirma que essa interpretação da razão pública, como argumentação moral, não está explícita em Rawls, trata-se de uma interpretação de Vita. A razão pública é uma modalidade de razão ideal para justificação dos arranjos institucionais, no entanto, para Dworkin, mesmo na situação ideal, devemos considerar a
} 
O que não pode ocorrer é partirmos diretamente das nossas doutrinas abrangentes, mas sim trabalhar com as idéias básicas de uma concepção política de justiça, e, a partir delas, derivar princípios.

“(...) we are required first to work to the basic ideas of a complete political conception and from there to elaborate its principles and ideals, and to use the arguments they provide. Otherwise public reason allows arguments that are too immediate or fragmentary". Rawls (1997:778)

Rawls relaciona o conceito de razão pública com cidadania ou civilidade. Existe apenas uma razão pública e várias razões, a estas Rawls denomina de cultura de fundo. A razão pública é uma forma de argumentação, sobre o que deve ser feito pelos órgãos coletivos e pelos indivíduos. Para ser uma argumentação precisa incorporar os princípios da razão, incluir critérios de correção e de justificação.

Nossa aceitação das doutrinas abrangentes, que são de livre escolha, faz parte dos direitos constitucionais que os indivíduos possuem. Que o Estado ser guiado pela razão pública não altera esse cenário. Os limites para a razão pública somente se aplicam para “os elementos constitucionais essenciais” e de justiça básica. Ficamos então apenas com os valores políticos.

O conceito de razão pública deriva da concepção de cidadania de uma democracia constitucional, já que, como foi dito, trata da relação entre os cidadãos livres e iguais e da relação destes com a estrutura básica da sociedade. A questão que emerge, portanto, é como essas pessoas com concepções de bem tão distintas podem aceitar justificar suas decisões políticas perante os demais? A resposta de Rawls é que cidadãos razoáveis são capazes de oferecer termos equânimes de cooperação, irão aceitar as diferentes visões de mundo de cada um. 
"Citizens are reasonable when, viewing one another as free and equal in a system of social cooperation over generations, they are prepared to offer one another fair terms of cooperation according to what they consider the most reasonable conception of political justice; and when they agree to act on those terms, even at the cost of their own interests in particular situations, provided that other citizens also accept those terms." Rawls (1997:770).

No construtivismo político, o conceito de razoável é fundamental para a busca de um patamar comum. Cidadãos razoáveis, ao aceitarem que todos são livres e iguais, também são capazes de aceitar as diferentes concepções de bem. O’Neill (1997) argumenta que Rawls caracteriza a razoabilidade como “política e não psicológica”, correspondendo com a sua visão de que a justiça não é metafísica mas política. Assim, ele coloca a base do acordo razoável entre agentes que são concebidos como cidadãos livres e iguais. Isso faz toda a diferença e é onde está a força da concepção de razão pública de Rawls, da conexão que ela faz com os cidadãos. Não são apenas indivíduos movidos por interesses próprios, mas que vêem os demais como livres e iguais.

"Being a citizen with a sense of political identity is much more than being one of the plurality of beings capable of rational and reasonable justification, and cognizant of the limits placed on reasonableness by the burdens of judgment: it is constitutive of reasonableness." O'Neill (1997:418).

É fundamental que a razão pública, portanto, seja neutra em relação às diferentes doutrinas abrangentes. Esse é o objetivo do liberalismo político, ser o mais neutro possível em relação a todas as doutrinas abrangentes ${ }^{219}$. Por isso, se pode afirmar que a questão mais importante em LP é a da legitimidade.

O conceito de razão pública está relacionado com a reciprocidade e a publicidade. A publicidade é um elemento fundamental para a aceitação de todos dos princípios de justiça e a reciprocidade diz que podemos encontrar uma razão para aceitá-los na aceitação dos outros. São elementos importantes para a estabilidade de uma concepção de justiça.

219 Dreben (1999:326). 
"When citizens adopt certain principles of justice for reasons they understand one another to acknowledge, their joint endorsement of the principles amounts to showing one another respect. Their grounds for embracing them do not lie solely in their own, but in a shared point of view." Larmore (2003: 373)

Somente com os princípios de justiça, através dos quais as pessoas encontram uma base comum de acordo, poderão elas demonstrar respeito uma pelo outra. Assim, a comunidade política de Rawls se baseia nesse respeito mútuo.

Para Larmore (2003), o conceito de publicidade evoluiu desde a TJ e não pode ser tomado apenas como a idéia de que todos devem conhecer os princípios de justiça. É mais do que isso. A concepção de justiça satisfaz a condição de total publicidade quando se justifica de forma que todos a aceitem. Por isso, segundo o autor, Rawls conectaria publicidade com o ideal da equidade de forma direta sem utilizar a metáfora do contrato 220 .

Mas as pessoas devem trazer para a deliberação apenas convicções que podem fazer parte de um ponto de vista compartilhado, assim não podemos incluir nossas convicções morais, religiosas ou filosóficas. Nas questões públicas devemos buscar esse patamar comum nos nossos valores políticos e não nas doutrinas abrangentes. Daqui derivamos o conceito de “consenso sobreposto”:

\begin{abstract}
"The basic sense in which principles of justice ought to be the object of consensus is that each person should have both sound and identical reasons to embrace them, for only then does their publicity give expression to mutual respect. Consensus so understood is therefore hardly identical to the extent of agreement about justice that actually obtains in a society.” Larmore (2003:377)
\end{abstract}

\footnotetext{
${ }^{220}$ Larmore (2003) compartilha com Dworkin a discussão sobre a validade do contrato conforme texto de LDS. Mas, para ele, a validade do contrato não está apenas ligada à aceitação das partes, mas a que os princípios sejam públicos, ou seja, nossa razão para aceitá-los se torna a razão para os demais aceitarem. Ver pp. 370-71. Para O’Neill (1997) que, como Rawls não apresenta hipótese sobre a motivação individual, a sua concepção de justificação se mantém formalmente contratualista. "His account of public justification is an account of the basis for the convergence of wills among fellow citizens. As in A Theory of Justice, Rawls seeks to rework the theory of the social contract." Ver O’Neill (1997:421).
} 
A razão pública, portanto, é a arena de debate de uma democracia deliberativa e deve ser capaz de reconhecer e aceitar os diferentes valores políticos. Ela não requer que sempre cheguemos a um acordo geral, mas que o debate nos leve a um entendimento das diferentes visões das pessoas acerca dos valores políticos. As decisões provenientes da razão pública não podem ser classificadas como corretas ou verdadeiras, mas como razoáveis e legítimas. São legitimas porque são apoiadas por cidadãos razoáveis, de um regime político cuja escolha está de acordo com a idéia de razão pública. A legitimidade para Rawls está ligada a essa forma de argumentação. Ele, inclusive, faz uma comparação entre a razão pública e a atuação dos juízes:

\begin{abstract}
"Recall that public reason sees the office of citizen with its duty of civility as analogous to that of judge with its duty of deciding cases. Just as judges are to decide cases by legal grounds of precedent, recognized canons of statutory interpretation, and other relevant grounds, so citizens are to reason by public reason and to be guided by the criterion of reciprocity, whenever constitutional essentials and matters of basic justice are at stake." Rawls (1997: 797).
\end{abstract}

Ele prossegue na comparação, dizendo que quando estamos diante de um impasse, ou usando as palavras de Dworkin, num hard case, os juízes não podem apelar para suas convicções pessoais, e o mesmo serve para a razão pública. Mas por que nos comparar a juízes? Por que devemos ser imparciais quando estamos diante das nossas escolhas? Em hard cases, Dworkin responde que devemos interpretar o caso à sua melhor luz, vendo o direito como um romance em cadeia. E a resposta que ele nos dá para o debate é mantermos uma continuidade entre ética e moralidade. Rawls afirma que se apelarmos para as nossas convicções pessoais o princípio da reciprocidade seria violado. Por quê? O argumento: devemos escolher o que é mais razoável. Na razão pública, assim como na posição original, as vemos como iguais, mas isso não quer dizer que precisamos deixar do lado de fora da "sala do júri” nossos valores. Os cidadãos são vistos por Rawls através de uma concepção política de pessoa. Acredito que Rawls não apresenta argumentos suficientes para imaginarmos que a razão pública garante a legitimidade do debate público. 
A limitação imposta pela razão pública, segundo Rawls, se faz necessária porque é preciso estabelecer uma base para a argumentação política que todos possam compartilhar como cidadãos livres e iguais. A noção de verdade das doutrinas abrangentes é substituída por uma idéia politicamente razoável de cidadãos para cidadãos. Assumir as doutrinas abrangentes violaria o critério de reciprocidade da razão pública, ou seja, de aceitação mútua.

\subsubsection{A Crítica de Sandel}

A questão de Dworkin sobre a separação entre ética e moralidade também foi tema em Sandel (1994) que a abordou sob outra perspectiva. Este destaca que uma terceira onda de trabalhos sobre o LP teve por foco a relação entre o correto e o bom. Muito desse debate tratou de tipos diferentes de concepções da pessoa e como devemos entender nossa relação com nossos fins. Na TJ, a prioridade do correto se conecta com uma concepção kantiana de pessoa ${ }^{221}$, na qual somos livres, independentes, sem amarras morais antecedentes e capazes de formular objetivos. Esta concepção adere perfeitamente à neutralidade do Estado em relação às concepções do bem. Mas no LP Rawls afirma que não depende dessa concepção kantiana de pessoa, nem de qualquer outra concepção. Essa mudança ocorre porque a idéia de que as pessoas compartilhariam os princípios de justiça com base numa doutrina abrangente é irrealista dado o pluralismo razoável. Ele deixa de lado um possível "liberalismo abrangente” na TJ, para defender o "liberalismo político".

Sandel (1994) questiona: por que Rawls insiste que as nossas reflexões sobre a justiça não devem fazer referência aos nossos objetivos e propósitos?

\footnotetext{
${ }^{221}$ Segundo Sandel (1994:1770), a concepção de pessoa independe da posição original, requer apenas a formulação feita na parte III da TJ.
} 
"Why must we "braket", or set aside, our moral and religious convictions, our conceptions of the good life? Why should we not base the principles that govern the basic structure of society on our best understanding of the highest human ends?" Sandel (1994: 1772-3)

A resposta que temos no LP é que o que justifica o desenho da posição original é a concepção política de pessoa, que não está presa a nenhum dever ou obrigação anteriores. A nossa identidade como cidadãos não é definida pelos nossos objetivos mais pessoais e não é afetada por mudanças na nossa concepção de bem. Temos, assim, uma identidade pública e uma identidade pessoal, mas a primeira, como entes públicos, deve estar separada de quaisquer concepções de bem. É essa concepção política de pessoa que nos leva a abstrair dos nossos objetivos na posição original.

A separação entre as duas identidades é tratada por Rawls no LP, quando ele afirma que tal dualismo é da natureza da cultura política democrática. Nas sociedades democráticas, faz-se a distinção entre as duas identidades, o que é bem diferente de sociedades tradicionais que moldam sua vida política baseadas em doutrinas abrangentes $^{222}$.

Para Sandel, ao afirmar que as virtudes liberais estariam restritas aos propósitos políticos, abre-se um espaço para algumas críticas ao liberalismo político. A primeira é que nem sempre seria razoável deixar de fora, por razões políticas, questões provenientes das doutrinas abrangentes. Ainda, que o ideal da razão pública seria uma restrição muito severa que empobreceria o discurso político e atacaria dimensões da deliberação política.

No caso da primeira crítica, a questão é que para o LP essa separação entre identidade pública e privada, ou, na linguagem dworkiana, entre ética e moralidade, é uma

\footnotetext{
${ }^{222}$ Sandel (1994) cita a análise de Rorty, que afirma que Rawls não está comprometido com uma concepção do eu, mas com uma descrição histórico-sociológica de como vivemos hoje.
} 
condição necessária para assegurar a cooperação na base do respeito mútuo. Para Sandel, essa condição necessária implica a prioridade dos valores políticos sobre os demais quando estamos tratando de controvérsias políticas. Quando estamos discutindo o direito ao aborto, Sandel afirma que não se pode ser neutro em relação às convicções morais e religiosas. Essa relação entre estas convicções e aborto é questionada pelos liberais, porque não respeita a prioridade do correto sobre o bem, mas nesse debate não é possível a separação. Se a questão é quando a vida começa, na concepção ou depois da formação da consciência, cairemos nessa armadilha.

O segundo exemplo é o debate sobre a escravidão entre Abraham Lincoln e Stephen Douglas em 1858. O argumento de Douglas é que a questão sobre a escravidão não deveria ser tratada pelo Estado, mas deixada a cargo dos territórios É o mesmo argumento, segundo Sandel, que alguns liberais utilizam ao afirmar que a mulher deveria decidir sobre o aborto. Uma forma de isolar as doutrinas abrangentes e deixar o problema para outro resolver. Mas Lincoln era contra essa resolução, considerava que se tratava de uma controvérsia moral. Como o liberalismo responderia a essa questão? Se considerasse a concepção kantiana de pessoa, argumentaria contra a escravidão já que estaríamos tratando as pessoas como meios e não como fins. Mas esse argumento o liberalismo político não poderia utilizar; naquela época, ele apoiaria a posição de Douglas. Claramente, com a cultura de hoje, nossos avanços, ele teria força para se contrapor à escravidão.

Rawls (1997) questiona Sandel, afirmando que seu argumento não foi entendido, que a razão pública não apoiaria Lincoln contra Douglas. Ele afirma que não faz sentido, já que eles estavam debatendo "rights and wrongs of slavery"223. A visão de Lincoln não estaria sendo sustentada por uma doutrina abrangente e, portanto, a razão pública daria conta do debate.

${ }^{223}$ Rawls (1997:802) 
"Since the rejection of slavery is a clear case of securing the constitutional essential of the equal basic liberties, surely Lincoln's view was reasonable (even if not the most reasonable), while Douglas's was not. (...) What could be a better example to illustrate the force of public reason in political life?” Rawls (1997:802)

Numa nota de rodapé, Rawls afirma que não podemos considerar que concepções políticas não seriam morais, ao contrário, são intrinsecamente idéias morais e um tipo de valor normativo. Ele está em desacordo com a afirmativa de que as concepções políticas são determinadas pelo que as instituições são hoje, ou que o político (the political) seria determinado pela política (the politics). Se assim fosse, não faria parte da razão pública, porque seria determinado pela política pessoal.

"To say that the political is determined by a people's politics may be a possible use of the term political. But then it ceases to be a normative idea and it is no longer part of public reason. We must hold fast to the idea of the political as a fundamental category and covering political conceptions of justice as intrinsic moral values.” Rawls (1997:802, nota 91).

Para Sandel, nos dois casos seria preciso apelar para as nossas convicções pessoais, e o liberalismo político não nos ajudaria a negar a escravidão ou mesmo a debater sobre o aborto.

Mais adiante, Sandel afirma que a limitação imposta para a razão pública prejudicaria o debate. O argumento é que, no LP, há a proteção da liberdade de expressão, mas, de outro lado, limita outros tipos de argumentos para aquele debate. Essa limitação refletiria a prioridade do correto sobre o bem. A forma de saber se estaríamos cumprindo o ideal da razão pública é nos comportarmos como juízes. Essas restrições deveriam prestar um serviço para alcançarmos a tolerância, mas deixar de fora a doutrina moral da igreja católica nos debates sobre o aborto, ou mesmo sobre os direitos civis, parece ter efeito contrário. Já Dworkin argumenta que a democracia e um debate genuíno podem ser resgatados justamente com uma visão mais ampla, partindo de um patamar comum, mas permitindo, já que seria impossível, não apelarmos para as nossas convicções mais profundas. 
Poderíamos argumentar que a forma como Rawls formulou a razão pública inicialmente segue sua trajetória de teoria ideal. Mas mesmo numa teoria ideal é possível dizer que questões políticas como o direito ao aborto leva-nos necessariamente a uma tentativa de “consenso" das nossas doutrinas abrangentes. O instrumento da razão pública seria então desnecessário, no entanto vimos que a base da reciprocidade e da civilidade no liberalismo política está na forma da razão pública. A neutralidade do Estado em relação às concepções de boa vida foi “modelada” pela razão pública. O contra-senso evidenciado por Sandel (1994) é que a liberdade de expressão é um dos direitos fundamentais para um liberal, mas, nesse caso, ela não poderia ser totalmente exercida. Não é possível afirmar que a idéia do proviso, que “permite” a presença das doutrinas abrangentes, quer responder às críticas com relação à razão pública feitas por Sandel, mas enfraquece sua estrutura. O próprio Rawls (1997) admite que a democracia e suas instituições são ameaçadas por doutrinas abrangentes não razoáveis ao impedirem que o ideal da razão pública se realize na sua completude. Mas é possível argumentar de outra maneira; é precisamente porque não temos um debate genuíno, amplo e baseado em princípios comuns que a democracia é ameaçada. Esperamos aprofundar esse argumento na seção seguinte.

Sandel (1994) vai na mesma linha de Dworkin (2006b) sobre como o debate público norte-americano está dividido e que um certo discurso liberal de neutralidade apenas dificulta o consenso.

“ (...) American political discourse in recent decades has come to reflect the liberal resolve that government be neutral on moral and religious questions, that fundamental questions of public policy be debated and decided without reference to any particular conception of the good. But democratic politics cannot along aside a public life as abstract and decorous, as detached from moral purpose, as Supreme Court is supposed to be. A politics that brackets morality and religion too completely soon generates its own disenchantment. (...) its vision of public reason is too spare to contain the moral energies of a vital democratic life. It thus creates a moral void that opens the way for the intolerant and the trivial and other misguided moralisms”. Sandel (1994: 1793-4) 
Para Sandel, a razão pública nos leva à intolerância, mas Dworkin usa outro argumento que vamos apresentar em seguida. Para ele, o debate somente é possível quando não temos como objetivo o ideal da razão pública.

\subsection{Dworkin e a Razão Pública}

Dworkin faz uma análise direta da razão pública em textos mais recentes ${ }^{224}$. Ele admite que a sua idéia de interpretação foi inspirada no conceito de equilíbrio reflexivo de Rawls, mas a sua crítica está na doutrina da razão pública. Ele faz essa ressalva num curto ensaio, "Rawls and the Law", 25 como uma tentativa de mostrar como o equilíbrio reflexivo poderia ser utilizado para chegarmos a algum conceito de direito. Dworkin até aceita, em seu argumento principal, que as doutrinas religiosas estejam fora do debate público, mas não que as demais também sejam excluídas. Entende que a razão pública tem dois requisitos: o primeiro é da reciprocidade, que aceita apenas justificações que todos os membros razoáveis possam aceitar. O outro requisito é que as justificações oferecidas somente podem se basear em valores políticos da comunidade e não em doutrinas abrangentes razoáveis.

Parece, para ele, que a reciprocidade não exclui as doutrinas abrangentes. No caso das religiosas poder-se-ia dizer que é um caso especial, já que parece mais complicada a aceitação da fé alheia. É possível considerar que a religião é algo mais difícil de ser compartilhado. Adiante, completa que não compreende a distinção feita entre as convicções políticas, que são permitidas no debate, e as demais convicções morais abrangentes. O próprio Rawls, insiste Dworkin, baseia seu princípio da diferença em pressupostos morais que são controversos, por exemplo, a irrelevância moral da

\footnotetext{
${ }^{224}$ Ver Dworkin (2006a) e Dworkin (2006b).

${ }^{225}$ Dworkin (2006a).
} 
responsabilidade pessoal. Quando se coloca a razão pública em operação, a limitação se torna mais clara.

Nas discussões que Rawls faz sobre o aborto, Dworkin afirma que é impossível não incluir as doutrinas abrangentes. Dizer que o feto não tem interesses e direitos é assumir uma posição, e não se pode discutir a questão sem decidir se o feto tem ou não direitos. Essa é uma questão moral e não política.

Ao contrário do equilíbrio reflexivo, a razão pública não pode ajudar na questão legal e podemos dizer o mesmo para a questão da justiça. Com o método de interpretação, não há necessidade de uma doutrina como a razão pública. Segundo Dworkin, pedir para um juiz deixar de lado suas convicções pessoais é impossível e isso independe da teoria sobre o direito sobre a qual estamos discutindo.

"A judge's intellectual biography is not a legal argument. But if it means that a judge may not give any place to controversial moral opinions in his judgment, because he would then be citing the moral opinions that he but not others think right, then it states an impossible demand. On no conception of law- positivist or interpretivist - can judges in complex pluralistic community acquit their institutional responsabilities without relying on controversial moral convictions”. Dworkin (2006a:254).

Novamente, Dworkin quer nos convencer de que não é preciso haver essa separação entre convicções políticas e demais doutrinas abrangentes. Do nosso ponto de vista, faltou a Dworkin explicitar como essa abordagem nos protege das arbitrariedades e de pessoas ou grupos que buscam apenas seu interesse próprio. Parece-nos coerente dizer que a resposta se encontra no direito e não na sua teoria da justiça, o que revela sua incompletude. O liberalismo abrangente quer tornar a igualdade, a liberdade e a comunidade elementos de uma única virtude. Rawls está preocupado com a estabilidade da justiça como equidade, já que é irreal pensar que os indivíduos compartilham princípios de justiça sob uma doutrina abrangente. Mas a necessidade de isolar o político do pessoal com a razão pública vem da própria estrutura de escolha dos princípios de justiça. A posição original é a formulação em que se parte de uma situação equitativa. É fundamental para a justiça como equidade, partirmos de uma 
situação equitativa ex post. Em Dworkin, o véu de ignorância é muito mais fino e a igualdade a que ele quer chegar é ex ante. Isso entendido parece, ele parece liberado de uma tradição contratualista.

O argumento de Dworkin é que mesmo nas questões de "fundamentos constitucionais" e de “justiça básica” devemos ter a continuidade entre ética e moralidade, diferente da proposta de Rawls. $^{226}$

\subsection{A Filosofia Prática de Dworkin: Um debate abrangente}

Como salientamos no primeiro capítulo, Dworkin quer buscar um patamar comum para tratar dos conflitos políticos que dividem uma sociedade. O seu entendimento acerca de um liberalismo abrangente, com as virtudes como liberdade, igualdade e comunidade como parte de um único ideal político, integra a sua teoria normativa. $\mathrm{O}$ que vamos apresentar é como podemos aplicar o conceito mais abstrato da igual consideração e respeito para questões polêmicas e, a princípio, irreconciliáveis.

"We are no longer partners in self-government; our politics are rather a form of war”. Dworkin (2006b:1).

\footnotetext{
${ }^{226}$ Vita (2007:281) afirma que a razão pública não seria tão restritiva quanto se afirma. Rawls não seria "obcecado pelo valor da não-interferência na autonomia individual”, assim como não veria com "desconfiança as deliberações coletivas". A neutralidade do contratualismo ralwsiano que se pretende garantir é a neutralidade de justificação e não de resultados. Para Vita, essa é uma distinção importante que o próprio Rawls já faz, entre neutralidade de propósito e neutralidade de efeito. Significa que a neutralidade decorrente do ideal da legitimidade política que se busca no liberalismo político se aplica às justificações para os fundamentos constitucionais, e não para os resultados ou tipo de políticas. As críticas dirigidas ao liberalismo político de Rawls normalmente confundem esses dois tipos de neutralidade. Mas Dworkin, na sua distinção entre tratar as pessoas como iguais e tratá-las igualmente, sugere que ele não quer uma justificação dos resultados, mas do processo como um todo, com base na igual consideração e respeito. Creio que Dworkin compartilha dessa visão de que o impacto será distinto e que seu objetivo é também uma neutralidade de justificação, mas que não é invalidada ao permitir que a ética e a moralidade estejam presentes no conteúdo de uma razão pública - vista exatamente como ideal do argumento moral, e não apenas da deliberação política concreta.
} 
O argumento de Dworkin é que pessoas que compartilham um patamar comum em princípios políticos básicos debatem quais as políticas melhor refletem esses princípios compartilhados. Ele acredita que é possível encontrar princípios compartilhados para engendrarmos um debate político profícuo, sem apelar para uma concepção de razão pública. O que ele oferece é um patamar comum para os norte-americanos, mas que podemos pensar para outras democracias constitucionais. Segundo ele, os liberais não foram capazes de criar um estatuto de seus princípios e defendê-los. Por isso, ele quer apresentar uma forma de liberalismo baseada nesse patamar comum. Diferentemente de Rawls, que tem um projeto mais idealizado, Dworkin quer “construir" uma versão do liberalismo a partir da crise da democracia, e não partir dela para construir princípios de justiça.

"I hope to persuade enough people that this popular opinion is wrong that it is profitable to study our most heated political controversies at a more philosophical level - to help begin a process that might later reinvigorate the argumentative dimension of our politics". Dworkin (2006b:8).

Para isso, o autor propõe que esse patamar comum seja alcançado não em questões concretas, mas em princípios abstratos. Segundo ele, a maioria de nós compartilha o que ele chama de princípios de dignidade: o princípio do valor intrínseco e o princípio da responsabilidade especial, já descritos no primeiro capítulo. Importante notar que os princípios são individualistas, mas não pressupõem que a vida de cada indivíduo deva ser independente do sucesso da sua comunidade ${ }^{227}$. Os dois princípios se referem aos valores políticos da igualdade e da liberdade, respectivamente.

Duas questões polêmicas serão discutidas: o papel da religião na política e o imposto. No primeiro caso, Dworkin aponta que a religião sempre teve um papel relevante na política americana e a controvérsia é justamente saber até onde ela pode participar. Questões como aborto, casamento gay, o ensino das teorias sobre a origem do homem,

\footnotetext{
${ }^{227}$ Dworkin não explicita no texto os conceitos sobre indivíduos integrados, mas, como vimos, toda a sua obra, seja no direito ou na filosofia política, defende a noção de uma comunidade personificada.
} 
passam a ser questões religiosas. Como podemos discutir essas questões diante da controvérsia que as envolvem? Devemos ter uma nação religiosa tolerante com os agnósticos ou uma nação secular que tolere a religião? Na prática, a América tem uma mistura dos dois tipos de Estado, o primeiro endossa uma religião, e a considera uma força positiva para a sociedade, o último é tolerante com todas as religiões e até mesmo com os agnósticos. Quaisquer cerimônias, rituais públicos não fazem menção a qualquer religião, ou seja, não permitiria que suas instituições fossem palco de prática religiosa.

A liberdade religiosa para um Estado religioso tolerante não está relacionada com o direito a fazer um aborto ou a casamentos homossexuais. Estas não são questões religiosas, essas práticas serão proibidas, mas não violam a liberdade religiosa. Já um Estado secular tolerante não considera a religião um fenômeno tão especial para encontrarmos uma justificação para o direito à liberdade religiosa. Assim, esse Estado secular deve buscar uma justificativa para a liberdade religiosa num princípio mais básico de liberdade, como um caso especial de liberdade ética. Esse princípio deverá dar conta de todo o tipo de escolha que podemos fazer para as nossas vidas.

O modelo secular tolerante não é o modelo histórico americano e a Suprema Corte, na análise do autor, está tentando resgatar o Estado religioso tolerante. De qualquer forma, seguimos com a tentativa de encontrarmos um patamar comum para a o debate que será o oposto à estratégia da razão pública, conforme ele explicita claramente:

"For some time many liberal academic philosophers in America have
tried to insulate their discussion of political policy from more general
issues of ethical and moral philosophy and in particular from issues of
theology. That political community will wish to live together on terms of
mutual respect and accommodation and will therefore accept the
constraints of what the very influential philosopher John Rawls called
public reason." Dworkin (2006b:64)

O debate de Dworkin é justamente se devemos aceitar essa restrição imposta pela razão pública. Primeiramente, ele afirma que parte da população não separa suas 
convicções religiosas dos princípios políticos, porque elas também as consideram princípios políticos. A celebração de seu Deus se faz, não apenas privadamente, mas como cidadãos. Fé e patriotismo são inseparáveis. Apesar de ser recomendável a separação, como cidadãos eles não estariam sendo sinceros e autênticos se o fizessem. Para Dworkin, a questão da liberdade religiosa mostra como o projeto do liberalismo político de Rawls apresenta limitações ao tentar insular as convicções políticas das demais doutrinas abrangentes.

A estratégia de Dworkin será distinta porque vai tentar encontrar um debate genuíno a partir dessas convicções mais profundas. É preciso responder que modelo de Estado é compatível com o princípio da responsabilidade especial. Ele quer nos mostrar que o princípio de responsabilidade especial exige um Estado secular tolerante, e não um Estado religioso tolerante. Buscar a melhor interpretação de um princípio que compartilhamos.

A escolha entre os dois modelos de Estado é uma escolha entre duas teorias da liberdade ${ }^{228}$ : o Estado religioso tolerante nos apresenta uma definição estreita de liberdade religiosa, que não inclui questões como escolha sexual, direito a aborto, entre outros, e o Estado secular tolerante apresenta uma definição mais ampla, que inclui aquele tipo de escolha. Assumindo que a maioria dos americanos têm alguma religião e que também acreditam no princípio da responsabilidade especial, qual dos Estados é mais apropriado?

Para responder a essa questão, os dois modelos devem apelar para uma concepção mais geral de liberdade. Como justificar a importância especial da liberdade religiosa em dois tipos de Estados tolerantes? A tolerância do Estado religioso também se

\footnotetext{
${ }^{228}$ Dworkin faz um esclarecimento sobre o uso das palavras "liberty” e "freedom”. "Liberty” é usada para descrever um conjunto de direitos que o governo deve estabeler e fazer cumprir para proteger a responsabilidade ética individual. "Freedom" é usada de forma mais neutra, sempre que o governo impede alguém de agir conforme seus desejos, está limitando esse tipo de liberdade. Esta não é um valor político. O primeiro tipo de liberdade é um valor político, porque define quando os limites impostos pelo governo à minha conduta não é violação de liberdade.
} 
estende aos ateus, portanto também não há um lugar especial para a religião. É preciso responder a uma questão filosófica sobre o que a liberdade realmente significa.

Dworkin vai utilizar as interpretações que já apresentamos em capítulos anteriores para encontrarmos a resposta. Precisamos, de alguma forma, compatibilizar a responsabilidade especial com a liberdade que ela requer. Ele começa apresentando uma formulação que deve ser familiar, de que a liberdade (liberty) é o direito de fazermos o que desejamos com os recursos que são justos. Quando temos os recursos provenientes de uma distribuição justa, então não podemos considerar que a nossa liberdade é violada se o governo restringir nossa liberdade (freedom), se tiver razões distributivas plausíveis. Um exemplo, que veremos mais adiante, é que a taxação justa não fere a liberdade, mas a injusta sim.

Aqui o autor está utilizando os conceitos de liberdade e igualdade que tratamos no capítulo 2 e 3. São conceitos complementares e um deve ser tratado sob a luz do outro. Portanto, essa concepção de liberdade nos diz que as pessoas têm o direito de escolher e viver uma vida no espaço permitido pela distribuição justa de recursos adotada por aquela sociedade.

\begin{abstract}
“(...) if we accept the two principles of human dignity, we must work out the implications of each in the light of the other. If I accept both that everyone's life is of equal intrinsic value and that everyone has the same personal responsibility for his life as I do, then these assumptions must shape my definition of my own responsibility". Dworkin (2006b:70).
\end{abstract}

Assim, a definição da responsabilidade pessoal é moldada pela aceitação dos dois princípios de dignidade. O que é preciso agora é diferenciar as justificativas distributivas que são aceitas, e que não restringem a liberdade (freedom) das demais. A distinção se faz entre as justificativas de julgamento pessoal e as justificativas de julgamento impessoal. A primeira se baseia em uma teoria sobre qual vida é intrinsecamente boa, mas a última apela para valores que não são pessoais, relacionados com um determinado de estado de coisas. Ele dá o exemplo de regulação 
sobre as fábricas para a proteção de florestas. A justificativa impessoal é que as florestas são tesouros naturais.

Essa distinção é útil para afirmar que o princípio da responsabilidade está relacionado apenas com as responsabilidades referentes aos valores éticos pessoais. Desta forma, devemos analisar se as leis violam a dignidade ao usurpar a responsabilidade individual por nossos valores éticos, ou se são leis que exercem a responsabilidade da comunidade como agente moral. Portanto, a liberdade será prejudicada se uma determinada lei somente pode ser justificada no terreno do julgamento pessoal, como leis que determinam que o homossexualismo é crime. Do ponto de vista de Dworkin, e acredito, da maioria, tais questões deveriam ser decididas no campo da ética pessoal e não comunitária ${ }^{229}$. Assim, a aceitação do modelo de Estado secular tolerante é compatível com os princípios de dignidade.

Para reforçar essa questão, Dworkin aborda o papel da cultura para o controle de nossas vidas. Muitos argumentam que a cultura tem aval para fazer esse controle. No entanto, o autor argumenta que a cultura é determinada por uma série de ações individuais, assim como pela lei, quando se define algum tipo de política econômica, por exemplo. O discurso dos conservadores é que a cultura religiosa deve ser uma determinação do Estado, se a maioria assim desejar ${ }^{230}$.

\begin{abstract}
"The phrase is code for the culture that conservatives hope to create not through individual choice but through legal compulsion. The secular model insists, on the contrary, that our collective religious culture should be created not through the collective power of the state but organically, through the separate acts of conviction, commitment, and faith of people drawn to such acts.” Dworkin (2006b:76)
\end{abstract}

\footnotetext{
${ }^{229}$ Algumas leis não podem ser justificadas apenas do ponto de vista pessoal como a obrigatoriedade do cinto de segurança. Para Dworkin esse tipo de lei não ofende o princípio da responsabilidade individual porque poderia ser justificada de forma plausível, mas aquelas que são justificadas afirmando que a maioria sabe melhor o que é bom para o indivíduo, ofendem aquele princípio. De novo, Dworkin reforça sua crítica ao paternalismo através da sua versão de liberalismo,

${ }^{230}$ Dworkin faz referência a um discurso de George Bush que usava a frase "culture of life” para dar poder a uma maioria para determinar por meio legal qual cultura sua comunidade deve adotar.
} 
Parece que o modelo de Estado secular tolerante é o que melhor respeita nosso ideal de dignidade representado pelos princípios do valor intrínseco e da responsabilidade especial. Este último princípio não aceita qualquer tipo de subordinação, mas não nega a possibilidade da influência cultural. Também não nega leis que podem ser justificadas por uma razão distributiva plausível ou por julgamentos impessoais. Leis que são justificadas baseando-se numa determinada concepção de bem não podem ser aceitas.

"It [a dignidade] assigns us a positive responsibility to choose ethical values for ourselves, and though, as I said, we know we are influenced by a thousand dimensions of culture in making those choices, we must nevertheless refuse to accept subordination to a government that deliberately and coercively manipulates our choices. " Dworkin (2006b: 85)

Para Dworkin, justificativas baseadas em questões distributivas aceitas e em julgamentos impessoais não violam a responsabilidade especial e, portanto, não violam a dignidade. Por isso, o modelo secular tolerante respeita aquele princípio. Isso vale mesmo para os Estados cuja população é na maioria adepta de alguma religião. Essa mesma análise pode ser utilizada para discutir uma série de questões: aborto ${ }^{231}$, eutanásia, casamento gay, “compromisso de fidelidade pública”232, entre outros. Dworkin faz uma discussão interessante sobre o papel da ciência, relacionada com o ensino das diferentes teorias sobre a origem da vida ${ }^{233}$. Uma controvérsia entre o

\footnotetext{
${ }^{231}$ A proibição do aborto, segundo Dworkin, é baseada numa justificativa de julgamento pessoal. Em O Domínio da Vida, ele dedica sua discussão das questões éticas acerca do aborto e da eutanásia. Um de seus argumentos é que devemos analisar se o feto ou a pessoa inconsciente tem ou não interesses, e, portanto, direito de proteger esses interesses. $\mathrm{O}$ feto não teria esses interesses porque não tem uma vida mental para isso. As pessoas inconscientes, ao contrário, os têm.

232 "Pledge of allegiance" é o pronunciamento oficial de fidelidade política recitado em escolas e em algumas cerimônias. É voluntário e, a princípio, ecumênico.

${ }^{233}$ Essa discussão sobre ensino, assim como o casamento homossexual e o "pledge of allegiance" foram temas de Dworkin (2006c). Danis Rose (2006) na mesma publicação questiona Dworkin porque ele trata o darwinismo como uma teoria que é ditada, não por uma religião, mas por cientistas (materialistas). A resposta de Dworkin é que há uma diferença fundamental entre religião e ciência: "The conception of science I defended does suppose that explanations of phenomena that rely on supernatural assumptions are not scientific explanations, and must not be taught to students as such. But, as I emphasized, it does not follow that scientific explanations are the only respectable explanations or that nothing exists except what science can demonstrate or that Darwin proved that
} 
creacionismo e a teoria evolucionária. Para ele ambas as teorias devam ser ensinadas assim como devem ensinar a diferença entre ciência e razão.

\begin{abstract}
"We need a defensible conception of science not only for the intensely practical reason that we must prepare our children and youth to advance knowledge and to compete in the world's economy, but also to protect the personal responsibility of our citizens to their religious faith. We need to account of science, in our public philosophy of government, that does not make its authority depend on commitment to any set of religious or ethical values." Dworkin (2006b:83-4).
\end{abstract}

Dworkin se propõe a tocar em outra questão controversa sob as lentes da filosofia: os impostos. Segundo ele, os impostos têm uma função fundamental que é ser o principal mecanismo de redistribuição de renda. Os Estados Unidos vêm piorando sua posição entre os países mais desiguais do mundo desenvolvido, e as reduções de impostos que beneficiaram os mais abastados apenas aumentou o abismo entre ricos e pobres. Os mais conservadores querem redução dos impostos para reduzir ou eliminar as políticas redistributivas. Segundo eles, o nível atual de impostos da economia norte-americana é injusta com aqueles que produzem. Os liberais, por sua vez, acham injusto justamente a redução de impostos, penalizando as políticas redistributivas. Ambos usam o argumento da equidade, mas não nos dizem qual seria o nível adequado de imposto. Novamente, é preciso chegar a um debate genuíno, o que poderia ser construído assumindo a aceitação dos dois princípios de dignidade. Além dos princípios de dignidade, ele vai abordar outra questão que já definimos anteriormente, que é a legitimidade de um governo. Este será legítimo se tratar a todos com igual consideração e respeito. Devemos obrigação apenas a uma comunidade política que respeite a dignidade humana, tratando-nos como iguais. Se ambos os lados questionam o nível de impostos como uma questão de justiça, a pergunta a ser feita é: qual o nível

God does not exist. Those claims are themselves distinctly nonscientific: a scientist who said that since science cannot measure goodness or beauty nothing is good or beautiful would be guilty of bad science." in Rose (2006). 
de impostos que trata a todos com igual consideração e respeito? Ou, de forma mais refinada, qual "acordo político"234 trata as pessoas com igual consideração e respeito?

A resposta é que a igual consideração é alcançada quando todos têm os mesmos recursos, independente das escolhas ou da sorte de cada um. E essa concepção deve respeitar os dois princípios de dignidade. Dworkin afirma que podemos rejeitar os princípios de justiça de Rawls exatamente porque ele viola o que o princípio da responsabilidade requer. O princípio da diferença requer que toleremos a desigualdade apenas quando melhoramos a posição do pior posicionado. Ou seja, não depende das escolhas ou da responsabilidade de seus membros. O governo irá beneficiar mesmo aqueles que escolheram não trabalhar, assim como aqueles que sofreram de azar (sorte) bruto (a). É aqui que se quebra a conexão entre as escolhas pessoais e o destino pessoal, que o princípio da responsabilidade pessoal requer.

Dworkin (2006b) explicita mais claramente por que não devemos separar a ética da moralidade, utilizando todo o arsenal de conceitos que apresentamos nos capítulo anteriores. É papel da filosofia política buscar essa "geodesic dome” unificadora. Em sua concepção política de justiça, Rawls insiste que o debate apele apenas para princípios políticos e não para conviçcões éticas de como devemos viver as nossas vidas. Dworkin nos propõe utilizar as nossas convicções éticas mais profundas para identificar quais princípios políticas estão nelas cimentados, de onde poderemos encontrar um patamar comum.

"In my view we cannot construct a genuine argument in America now about the role of religion in public life if we accept such a limitation, because our distinctly political convictions are now too sharply different. We must try to identify more comprehensive ethical principles about dignity and personal responsibility that we share and then try to explore which of our conflicting political principles are more securely

\footnotetext{
234 “Political settlement”. Esse “acordo político” são todas as leis e políticas adotadas por uma comunidade e que têm efeito sobre os recursos e oportunidades de que os cidadãos dependem. Além das nossas escolhas pessoais, as escolhas do governa também afetam nossa vida, recursos e oportunidades. Por isso, faz sentido reformular a questão dessa forma mais específica. Ver Dworkin (2006b:98-9).
} 
grounded in those more fundamental ethical convictions.” Dworkin (2006b:104).

Para tratarmos do nível de impostos que é justo, não podemos deixar de lado questões de responsabilidade pessoal. Portanto, devemos rejeitar a teoria de justiça de Rawls e qualquer outra que não reconheça essa responsabilidade. Assim, o acordo político, ou uma política de impostos deverá tratar a todos com igual consideração e respeitar a responsabilidade pessoal de cada um. A igualdade de recursos com o mecanismo de seguro é a resposta que procuramos. É a igualdade ex ante com igual oportunidade para que cada um adquira um seguro contra a má sorte ou falta de talento. Essa política de impostos deve atacar a desigualdade na habilidade de cada um de se proteger da sorte bruta.

O seguro está relacionado com a igualdade ex ante, assim como o contrato com a igualdade ex post. Novamente, ele invoca a teoria de Rawls para o contraponto. Dworkin acredita que sua metáfora do seguro tem sido vastamente utilizada na prática, já que o seguro-desemprego é o que o próprio nome diz, um prêmio pago em caso de desemprego, além de outros tipos de seguro contra doença, acidentes, etc. O seguro é mais realista porque pode ser guiado pelo mercado de seguros já existente, além de identificar os programas redistributivos não como caridade dos mais ricos, mas como direitos adquiridos, além de evidenciar uma decisão individual de prudência e de responsabilidade. Ainda, proporciona racionalidade econômica para a comunidade, já que cada um de nós deverá decidir quanto da nossa renda será utilizada para a compra desse seguro. Mas ele argumenta que as coisas não são perfeitas assim, já que os programas de redistribuição não são voluntários como a nossa decisão de comprar ou não um seguro: as pessoas não possuem a mesma renda, o mesmo "risco" 235 . No entanto, insiste que a redistribuição via taxação é essencial para tratar as pessoas com igual consideração.

\footnotetext{
${ }^{235}$ Pessoas com doenças diagnosticadas, ou doenças degenerativas na família, podem ter seu seguro aumentado.
} 
Sua proposta é estabelecer uma taxação progressiva em relação à renda, cuja soma seja igual ao prêmio de seguro hipotético da comunidade. Esse seguro hipotético é quanto as pessoas razoáveis estariam dispostas a pagar se a renda da comunidade fosse igualmente distribuída entre eles, com total conhecimento dos riscos que correm. Esse seria o patamar ótimo de taxa de redistribuição para a comunidade.

O próprio seguro hipotético também pode ser visto como uma espécie de "redeprotetora” que determina um mínimo a ser alcançado. No entanto, o seguro teria uma vantagem, porque pode ser justificado como uma interpretação do que a igual consideração requer. Como defender uma "rede-protetora" inferior a do segurohipotético? Dworkin questiona.

Um argumento adicional para o seguro hipotético é que, diferente da igualdade $e x$ post, que não oferece um guia de redistribuição, ela garante receita para o que a igualdade requer. Um argumento conservador de que ele levaria a um excesso de despesas do governo poderia ser rebatido dessa forma. Ele termina seu argumento perguntando aos conservadores se a legitimidade não corresponde a tratar a todos com igual consideração, e se a igualdade ex ante não pode ser a medida que essa igual consideração requer. Enfim, é a partir da legitimidade e da justiça distributiva que a questão sobre impostos deve se basear. 


\section{Conclusão}

A discussão sobre a obra de Dworkin buscou “juntar as peças” para que pudéssemos apresentá-la como uma teoria liberal à altura do liberalismo político de Rawls. Uma alternativa às perguntas clássicas sobre justiça, tolerância, liberdade e igualdade. Dworkin, em suas contribuições para a filosofia política, abre caminhos para uma discussão mais abrangente e mais próxima da realidade. Não podemos exigir da filosofia política normativa mais do que ela se propõe a ser, mas o dever ser não pode ignorar aquilo que é.

Sua discussão sobre o não-conflito entre liberdade e igualdade tem implicações práticas fundamentais. Os políticos, assim como os operadores do direito, não poderão dizer que a liberdade e a igualdade são irreconciliáveis, e que a primeira deve ter prioridade. Há uma resposta alternativa para a questão.

Dworkin parece querer uma defesa do liberalismo, como Rawls, mas seus últimos textos evidenciam que sua preocupação é com a própria democracia. A legitimidade e a justiça são temas recorrentes e estão fundamentados na sua teoria do direito e na sua teoria da justiça. O direito fundamental e mais básico é que todos devem ser tratados com igual consideração e respeito. A partir daí faz-se a interpretação de como uma sociedade plural pode ser justa e respeitar os direitos individuais. A comunidade personificada, como agente moral, é elemento fundamental para o seu conceito de legitimidade, já que ela é a melhor justificativa para a coerção do Estado. Trazemos da teoria do direito uma noção mais sólida do papel da comunidade política cujo conceito é complementado na sua discussão sobre a igualdade liberal. A comunidade liberal é formada por cidadãos integrados, que se importam com o destino de seus compatriotas. A igualdade de recursos é a sua interpretação do que significa tratar a todos como iguais, uma igualdade ex ante, que protege os cidadãos das contingências da vida, mas os responsabiliza pelas suas escolhas. Está na responsabilidade especial a idéia de que o Estado deve ser tolerante diante do pluralismo. Os princípios de 
dignidade completam a sua análise exigindo que, se não forem respeitados, não podemos nos sentir parte desta comunidade.

Dworkin é um filósofo dos mais influentes na atualidade, sobretudo porque ele participa firmemente do debate público. Ele discute questões que são temas universais: o aborto, a eutanásia, a ação afirmativa, o papel da Suprema Corte, regras para financiamento de campanha, ensino religioso nas escolas públicas, etc. Suas últimas discussões sobre impostos e ensino religioso mostram como é preciso encontrar um terreno comum para o debate público. Inegavelmente, a Rawls devemos o ressurgimento da teoria política, da reflexão filosófica sobre a igualdade e a liberdade como virtudes, e de pensarmos as instituições como garantidoras da tolerância diante das diferentes visões de mundo. Mas diante de um mundo profundamente desigual, com divisões ideológicas não razoáveis, para usarmos as suas palavras, uma filosofia prática como exerce Dworkin abre caminhos promissores para um debate público genuíno. A literatura ainda não explorou na sua plenitude a proposta de um liberalismo abrangente e baseado na igualdade. Assim como os juízes não se "despem” das suas convicções mais pessoais para tomarem decisão, como os indivíduos poderão fazer o mesmo? Podem alegar que a divisão entre nações e os grandes conflitos ocorrem porque não isolamos as doutrinas abrangentes. É um bom argumento, mas por que não podemos assumir outra interpretação? Pode-se questionar o leilão hipotético, assim como o seguro, mas o mesmo pode ser feito com a posição original e a razão pública. Ambas as teorias são, em certa medida, interpretativas, e o dever dos estudiosos é apresentá-las na sua melhor forma. Dworkin considera que esta forma seria a de uma "geodesic dome".

Finalmente, podemos dizer que para Dworkin a razão pública rawlsiana não é necessária para garantir a estabilidade do liberalismo, este visto como um liberalismo abrangente e não como liberalismo político. Também não é preciso um ponto arquimediano, a posição original, para selecionar os princípios de justiça, nem a razão pública para atestar sua legitimidade. O liberalismo abrangente de Dworkin pretende resgatar a democracia americana a partir de um debate genuíno, cujo patamar se 
encontra nas questões éticas mais profundas representadas pelos princípios de dignidade. Como um liberal, Dworkin também não aceita qualquer interferência do Estado, qualquer imposição de concepções de bem; ao contrário, insiste, fortemente, que somos responsáveis pelas nossas escolhas e devemos ser tratados como iguais. A defesa que ele faz da igualdade é muito mais forte e ambiciosa, já que não pretende apenas nos oferecer um liberalismo contínuo entre a ética e moralidade, mas um liberalismo baseado na igualdade. Esperamos ter mostrado que possuímos duas interpretações liberais seminais para responder o que é ser tratado como igual e como defesa do liberalismo, mas se a busca é pela igualdade, creio ter apresentado aqui elementos para escolher a sua melhor interpretação. 


\section{Bibliografia}

ALEXANDER, L.; SCHAWARZSCHILD, M. Liberalism, Neutrality and Equality of Welfare vs. Equality of Resources. Philosophy and Public Affairs, vol. 16, $\mathrm{n}^{\circ}$ 1, pp 85-110, 1997.

ANDERSON, E. What is the Point of Equality?. Ethics, vol. 109, pp. 287-337, 1999.

BARRY, B. Theories of Justice. University of California Press, 1989.

BARRY, B. Justice as Impartiality. Clarendon Press, 1995.

BERKOWITZ, P. Easy Virtue. National Review, August, pp. 43-45, 2000.

BERLIN, I. Estudos sobre a Humanidade: Uma antologia de ensaios. Cia. das Letras, 2002.

BRESSER-PEREIRA, L.C. Os dois métodos e o núcleo duro da teoria econômica. Revista de Economia Política, vol 29, n² 2, pp. 163-191, 2009.

BRIGHOUSE, H. Justice. Polity, 2004.

BURLEY, J. Dworkin and His Critics. Blackwell Publishing, 2004.

BROWN, A. Ronald Dworkin's Theory of Equality: Domestic and Global Perspectives. Palgrave Macmillan, 2009.

CALABRESI, G. About Law and Economics: A Letter to Ronald Dworkin. Hofstra Law Review, vol. 8, pp. 553-562, 1979.

CLAYTON, M. Liberal Equality and Ethics. Ethics, vol. 113, outubro, pp. 8-22, 2002.

CLAYTON, M.; WILLIAMS, A. Egalitarian justice and interpersonal comparison. European Journal of Political Research, vol. 35, pp.445-464, 1999.

COHEN, G. A. On The Currency of Egualitarian Justice. Ethics, vol. 99, pp. 906-944, 1989.

COHEN, G. A. Rescuing Justice and Equality, Harvard University Press, 2008.

CÔRTES, N. Descaminhos do método: notas sobre história e tradição em Hans-Georg Gadamer. Varia Historia, Belo Horizonte, Vol. 22, n 36, pp. 274-290, 2006.

COTTERRELL, R. Liberalism's Empire: Reflections on Ronald Dworkin's Legal Philosophy, American Bar Foundation Research Journal, nº 2 e 3, pp. 509-521, 1987. 
CROWDER, G. (2003) Hedgehog and the Fox. Australian Journal of Political Science, vol. 38, no. 2, pp. 333-377, 2003.

DALL’AGNOL, D. O Igualitarismo Liberal de Dworkin. Kriterion, Belo Horizonte, no. 111, p.55-69, 2005.

DANIELS, N. Reading Rawls. Stanford Series of Philosophy, 1989.

DARWALL, S. Equal Freedom: Selected Tanner Lectures on Human Values. University of Michigan Press, 1995.

DAVION, V.; WOLF, C. The Idea of a Political Liberalism: Essays on Rawls, Rowman \& Littlefield Publishers, 2000.

DREBEN, B. “On Rawls and Political Liberalism”, 1999. In: Freeman. The Cambridge Companion to Rawls, Cambridge University Press, 2003.

DWORKIN, R. Dworkin's Rights Thesis. Michigan Law Review, vol. 74, no. 6, pp.1167-1199, 1976.

DWORKIN, R. Taking Rights Seriously. Harvard University Press, 1977.

DWORKIN, R. Is There a Right to Pornography? Oxford Journal of Legal Studies, vol. 1, no. 2, pp. 177-212, 1981.

DWORKIN, R. What Liberalism Isn’t. New York Review of Books, vol. 29, no. 21 e 22, 1983a.

DWORKIN, R. Why Liberals Should Believe in Equality. New York Review of Books, vol. 30, no. 1, 1983 b.

DWORKIN, R. Comment on Naverson: In Defense of Equality. Social Philosophy and Policy, 1, pp. 24-40, 1983c.

DWORKIN, R. A Matter of Principle. Harvard University Press, 1985.

DWORKIN, R. Ética Privada e Igualitarismo Político. Pensamiento Contemporâneo 29. Ediciones Paidos, 1993.

DWORKIN, R. Objectivity and Truth: You'd Better Believe It. Philosophy and Public Affairs, vol. 25, n² 2, pp. 87-139, 1996.

DWORKIN, R. Do Values Conflict? A Hedgehog’s Approach. Arizona Law Review, vol. 43:2, 2001.

DWORKIN, R. Sovereign Virtue Revisited. Ethics, vol. 113, outubro, pp. 106-143, 2002. 
DWORKIN, R. A Virtude Soberana: A teoria e a prática da igualdade. Editora Martins Fontes, 2005a.

DWORKIN, R. Uma Questão de Princípio. Editora Martins Fontes, 2005b.

DWORKIN, R. Justice in Robes. The Belknap Press of Harvard University Press, 2006a.

DWORKIN, R. Is Democracy Possible Here? Principles for a New Political Debate. Princeton University Press, $2006 \mathrm{~b}$.

DWORKIN, R. Three Questions for America. New York Reviews of Books, vol. 53, $\mathrm{n}^{\circ} 14,2006 \mathrm{c}$.

DWORKIN, R. O Império do Direito. Editora Martins Fontes, 2007a.

DWORKIN, R. Levando os Direitos a Sério. Editora Martins Fontes, 2007b.

DWORKIN, R. O Domínio da Vida. Editora Martins Fontes, 2009.

EVEnSKY, J. Adam Smith's Moral Philosophy: A Historical and Contemporary Perspective on Markets, Law, Ethics, and Culture. Cambridge University Press, 2005. FLEISCHACKER, S. A Short History of Distributive Justice. Harvard University Press, 2004.

FLEURBAEY, M. Fairness, Responsability, and Welfare. Oxford University Press, 2008.

FREEMAN, S. The Cambridge Companion to Rawls. Cambridge University Press, 2003.

FREEMAN, S. Rawls. Routledge Philosophers, 2007.

GADAMER, H. Hermenêutica em Retrospectiva. Editora Vozes, 1995.

GARGARELlA, R. As Teorias da Justiça Depois de Rawls: Um Breve Manual de Filosofia Política. Editora Martins Fontes, 2008.

GUEST, S. Ronald Dworkin. Jurists: Profiles in Legal Theory. Edinburgh University Press, 1997.

GUEST, S. Integrity, Equality and Justice. In: TRINITY COLLEGE MEETING $30^{\text {th }}$ NOVEMBER, 2004.

GUEST, S. How to Criticize Ronald Dworkin's Theory of Law. Analysis Reviews, vol. 69, no. 2, pp. 352-364, 2009. 
GUEST, S. (2008) Rawls, Cohen and Dworkin and the Real World. Disponível em: http://www.onlinelegalcoach.com/article/919/rawls-cohen-and-dworkin-and-realworld?page=0\%2C0. Acesso em: novembro, 2009.

HABERMAS, J.; RAWLS, J. (1998) Debate sobre el Liberalismo Político. Pensamiento Contemporaneo 45. Ediciones Paidós, 1998.

HART, H.L.A. Are there any natural rights? The Philosophical Review, vol. 64, no. 2, pp. 175-191, 1955.

HART, H.L.A. O Conceito de Direito. Fundação Calouse Gulbekian, Lisboa, 2a . Edição, 1994.

HERZOG, D. How to think about equality. Michigan Law Review, vol. 100, no. 6, pp. 1621-1638, 2002.

HURLEY, S. L. Justice, Luck, and Knowledge. Harvard University Press, 2003.

KYMLICKA, W. Filosofia Política Contemporânea. Ed. Martins Fontes, 2006.

LEVINE, A. Rethinking Liberal Equality: From a Utopian Point of View. Cornell University Press, 1998.

LARMORE, C. Public Reason. In: FREEMAN, S. The Cambridge Companion to Rawls, 2003.

LILLA, M.; DWORKIN, R. and Silvers, R (org.). The Legacy of Isaiah Berlin. New York Review of Books, 2001.

LOPES, A. A Hermenêutica Jurídica de Gadamer”. Revista de Informação Legislativa, vol. 145, $\mathrm{n}^{\circ}$ 37, pp. 101-112, 2000.

MACEDO JUNIOR, R. O método da leitura estrutural. Cadernos do Direito GV, vol. 6, pp. 3-41. 2007.

MACLEOD, C. Liberalism, Justice, and Markets: A Critique of Liberal Equality. Clarendon Press Oxford, 1998.

MAHONEY, J. Interpretation and Rights: A Critique of Dworkin. Law and Philosophy, Vol. 23, No. 2, pp. 187-222, 2004.

MARMOR, A. Direito e Interpretação. Editora Martins Fontes, 2004.

MCMURRIN, S. Liberty, Equality, and Law. Selected Tanner Lectures on Moral Philosophy. Cambridge University Press, 1987. 
MULHALL, S.; SWIFT, A. Liberals \& Communitarians. $2^{\text {nd }}$ Edition. Blackwell Publishing, 1996.

NOZICK, R. Anarchy, State and Utopia. Basic Books, 1974.

NUSSBAUM, M. Frontiers of Justice. The Belknap Press of Harvard University Press, 2006.

O’NEILL, O. Political Liberalism and Public Reason: A Critical Notice of John Rawls, Political Liberalism. The Philosophical Review, vol. 106, n 6, pp. 411-428, 1997.

OTSUKA, M. Luck, Insurance and Equality. Ethics, vol. 113, no. 1, Symposium on Ronald Dworkin's "Sovereign Virtue.", pp. 40-54, 2002

PIERIK, R.; ROBEYNS, I. Resources versus Capabilities: Social Endowments in Egalitarian Theory. Political Studies, vol. 55, pp. 133-152, 2007.

PILDES, R. Dworkin's Two Conceptions of Rights. The Journal of Legal Studies, vol. 29, No. 1, pp. 309-315, 2000.

POGGE, T. Can be Capability Approach be Justified? Philosophical Topics, vol. 30, $\mathrm{n}^{\circ} 2$, pp. 167-228.

RAZ, J. Dworkin: A New Link in the Chain. California Law Review, vol. 74, no. 3, pp. 1103-1119, 1986.

RAWLS, J. Two Concepts of Rules. The Philosophical Review, vol. 64, no. 1, pp.332, 1955.

RAWLS, J. A Theory of Justice. Harvard University Press, revised edition, 1971.

RAWLS, J. Justice as Fairness: Political not Metaphysical. Philosophy and Political Affairs, no. 14, pp. 223-51, 1985.

RAWLS, J. Political Liberalism. Columbia Classics in Philosophy. Columbia University Press, 1993

RAWLS, J. The Idea of Public Reason Revisited. The University of Chicago Law Review, vol. 64, n 3, pp. 765-807, 1997.

RAWLS, J. Justice as Fairness: A restatement, 2003. Erin Kelly (Editor). RIPSTEIN, A. Ronald Dworkin. Cambridge University Press, 2007.

ROBEYNS, I. The Capability Approach: An Interdisciplinary Introduction, 2003. Disponível em: www.ingridrobeyns.nl . Acesso em: Março, 2009. 
ROBEYNS, I. Capabilities and Theories of Social Justice, 2007. Disponível em: www.ingridrobeyns.nl. Acesso em: Março, 2009.

ROEMER, J. E. Theories of Distributive Justice. Harvard University Press, 1996.

ROSE, D. Darwin and Spirituality: An Exchange. New York Review of Books, vol. 53, $\mathrm{n}^{\circ}$ 17, 2006. Disponível em: www.nybooks/contributors/ronald-dworkin Acesso em: 2009 .

SANDEL, M. J. Political Liberalism by John Rawls. Harvard Law Review, vol. 107, no. 7, pp. 1765-1794, 1994.

SANDEL, M. J. Liberalism and the Limits of Justice. Second Edition. Cambridge University Press, 1998.

SCANLON, T.M. Contratualism and Utilitarinism in SEN, A; Williams, B. Utilitarianism and Beyond. Cambridge University Press, 1982.

SCANLON, T. M. What We Owe to Each Other. The Belknap Press of Harvard University Press, 2000.

SMITH, P. O Ceticismo de Hume. Coleção Filosofia n. 32. Edições Loyola, 1995.

SCHMITZ, D. Elements of Justice. Cambridge University Press, 2006.

SEN, A. On Economic Inequality. Oxford: Clarendon Press and New York: Norton, 1973.

SEN, A. “Equality of What?”.Tanner Lectures on Human Values. Stanford University, 1979. Disponível em: www.tannerlectures.utah.edu. Acesso em: Novembro, 2007.

SEN, A. Inequality Reexamined. Cambridge University Press, 1992.

SEN, A. The Possibility of Social Choice. Nobel Lecture, 1998. Disponível em: www.nobelprize.org/nobel_prizes/economics. Acesso em: Novembro, 2007.

SEN, A. Commodities and Capabilities. Oxford India Paperbacks, 1999.

SEN, A. Development as Freedom. Anchor Books, 2000.

SEN, A; Williams, B. Utilitarianism and Beyond. Cambridge University Press, 1982.

SEN, A. The Idea of Justice. The Belknap Press of Harvard University Press, Cambridge, 2009. 
SUGDEN, R. Welfare, Resources, and Capabilities: A Review of Inequality Reexamined by Amartya Sen. Journal of Economic Literature, vol 31, dez., pp. 1947-1962, 1993.

VITA, A. Justiça Distributiva: A Crítica de Sen a Rawls. Revista Dados, vol. 42, n. ${ }^{\circ}$ 3, 1999.

VITA, A. Uma concepção liberal-igualitária de justiça distributiva. Revista Brasileira de Ciências Sociais, vol. 14, n 39, pp. 41-59, 1999.

VITA, A. A Justiça Distributiva e seus Críticos. Martins Fontes, 2007.

VITA, A. O Liberalismo Igualitário: Sociedade Democrática e Justiça Internacional. Martins Fontes, 2008.

VITA, A. Sociedade Democrática e Tolerância Liberal. Novos Estudos CEBRAP, n 84, pp. 61-81, 2009.

WILLIAMS, B. Dworkin on Community and Critical Interests. California Law Review, vol. 77, no. 3, pp. 515-520, 1989.

WILLIAMS, B. Dworkin on Capabilities. Ethics, vol. 113, pp. 23-39, 2002.

WOLFE, C. Natural Law Liberalism, Cambridge University Press, 2006.

ZANGWILL, N. A Review of Ronald Dworkin's Objectivity and Truth: Would Better Believe it. BEARS Moral and Political Philosophy website, 1996. 